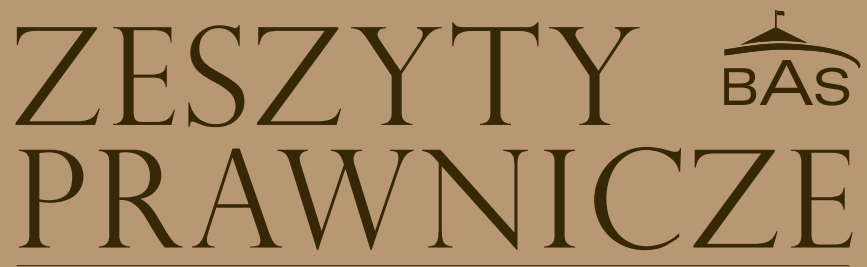

Biura Analiz Sejmowych Kancelarii Sejmu

Immunitet państwa w postępowaniu rozpoznawczym w sprawach cywilnych

Obowiązek opieki nad weteranami walk o niepodległość państwa polskiego

Stosowanie przepisów Kodeksu postępowania administracyjnego przez Sejm i jego organy

Ocena poselskich projektów o związku partnerskim 


\section{ZESZYTY \\ PRAWNICZE}

BIURA ANALIZ SEJMOWYCH

ROK XV • 3(59) - 2018 


\section{Rada programowa}

dr Ziemowit Cieślik, UKSW - przewodniczący - $\operatorname{dr}$ Piotr Czarny, UJ - dr Adam Łazowski, University of Westminster (London) - prof.zW. drhab. Cezary Mik, UKSW - prof.zw. drhab. KrzysztofSkotnicki, Ut dr hab. Adam Szafrański, UW - prof.zW. dr hab. Andrzej Szmyt, UG - prof. dr hab. Marek Szydło, UWr

\section{Zespół redakcyjny}

dr Wojciech Arndt, Akademia Ignatianum - redaktor naczelny - Marta Kopeć - sekretarz redakcji dr Piotr Chybalski, UKSW - dr Ewelina Gierach, UKSW - dr hab. Robert Jastrzębski, UW - dr Adam Karczmarek, UKSW - dr Krzysztof Kozłowski, UJ - Bartosz Pawłowski - dr hab. Jadwiga Potrzeszcz, KUL - dr Przemysław Sobolewski, UW - dr Zofia Szpringer - drhab. Michał Warciński, UW

\section{Redakcja tematyczna}

dr Ewelina Gierach - prawo konstytucyjne - dr Przemystaw Sobolewski - prawo cywilne i handlowe - dr Zofia Szpringer - prawo finansowe

\section{Redakcja językowa i korekta}

Teresa Muś

\section{Skład}

Janusz Świnarski

\section{Fotografia na okładce}

„Sprawiedliwość" - płaskorzeźba Aleksandra Żurakowskiego w Sali Posiedzeń Sejmu, fot. Mariusz Wideryński

\section{Kontakt z redakcja}

e-mail: marta.kopec@sejm.gov.pl

Biuro Analiz Sejmowych Kancelarii Sejmu

00-441 Warszawa, ul. Zagórna 3

tel. (+48 22) 6941845

faks (+48 22) 6941865

e-mail: punkt_konsultacyjny@sejm.gov.pl

e-mail:wydawnictwo_BAS@sejm.gov.pl

(c) Copyright by Kancelaria Sejmu

Warszawa 2018

Wszelkie prawa zastrzeżone. Żadna część ani całość opracowania nie może być bez zgody wydawcy - Kancelarii Sejmu - reprodukowana, użyta do innej publikacji oraz przechowywana w jakiejkolwiek bazie danych.

ISSN 2082-064X

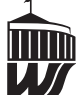

Wydawnictwo Sejmowe 


\section{SPIS TREŚCI}

1 ARTYKUŁY

Agnieszka Laskowska-Hulisz

Immunitet państwa w postępowaniu rozpoznawczym w sprawach cywilnych wybrane zagadnienia procesowe $\ldots \ldots \ldots \ldots \ldots$

Krzysztof Kozłowski

Obowiązek opieki nad weteranami walk o niepodległość państwa polskiego analiza konstytucyjnoprawna . . . . . . . . . . . . . . . . .

\section{OPINIE BAS}

A ZAGADNIENIA PRAWA KONSTYTUCYJNEGO

Piotr Chybalski

Wykładnia art. 47 ust. 2 pkt 1 regulaminu Sejmu - tryb rozpatrywania poprawek w komisjach . . . . . . . . . . . . . . . . . . . . . . . .

Wojciech Odrowąż-Sypniewski

Wykładnia art. 152 ust. 5 regulaminu Sejmu - powiadomienie członków komisji

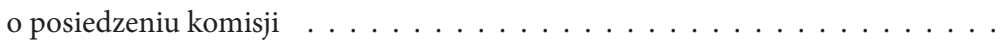

Ewelina Gierach

Stosowanie przepisów Kodeksu postępowania administracyjnego przez Sejm i jego organy . . . . . . . . . . . . . . . . . . . . . . .

Wojciech Odrowąż-Sypniewski

Wykładnia art. 23 ust. 2 regulaminu Sejmu - odwołanie od uchwały Prezydium Sejmu o obniżeniu uposażenia lub diety parlamentarnej $\ldots \ldots \ldots \ldots$

B ZAGADNIENIA PRAWA MIĘDZYNARODOWEGO I EUROPEJSKIEGO

\section{Cezary Mik}

Analiza stopnia implementacji postanowień konwencji dotyczących bezpaństwowców z 1954 r. i 1961 r. w prawie polskim . . . . . . . . . . . . . . . .

Zofia Szpringer, Ziemowit Cieślik

Projekt budżetu ogólnego Unii Europejskiej na rok budżetowy 2019 - Ogólne wprowadzenie - Ogólne zestawienie dochodów - Zestawienie dochodów i wydatków w podziale na sekcje . . . . . . . . . . . . . . .

C OPINIE LEGISLACYJNE

\section{Pawel Bachmat}

Odpowiedzialność karna za przestępstwa z art. 55a ust. 1-2 oraz kontratyp z art. 55a ust. 3 ustawy o Instytucie Pamięci Narodowej - Komisji Ścigania Zbrodni przeciwko Narodowi Polskiemu . . . . . . . . . . . . . . . .

\section{Beata Bińkowska-Artowicz}

Możliwość wprowadzenia w prawie łowieckim regulacji dopuszczającej polowanie z łukiem . . . . . . . . . . . . . . . . . . . . 


\section{Rafał Dubowski}

Związek partnerski czy małżeństwo? Ocena prawna poselskich projektów: ustawy o związku partnerskim oraz ustawy - Przepisy wprowadzające ustawę o związku partnerskim . . . . . . . . . . . . . . . . . . .

D SPRAWY POSELSKIE

\section{Irena Galińska-Rączy}

Termin przedawnienia prawa do odprawy emerytalnej przysługującej na podstawie art. 38 ustawy o wykonywaniu mandatu posła i senatora . . . . . . . . . . .

\section{Wojciech Odrowąż-Sypniewski}

Uprawnienie posła pozbawionego wolności do otrzymywania diety i uposażenia

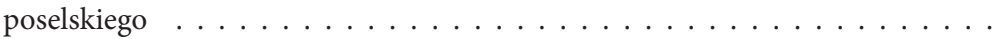

E VARIA

\section{Irena Galińska-Rączy}

Udostępnienie przez organ administracji rządowej - w trybie ustawy o dostępie do informacji publicznej - korespondencji w sprawie interwencji poselskiej organowi gminy, którego dotyczy ta interwencja $\ldots \ldots \ldots \ldots \ldots$

\section{Henryk Dzwonkowski}

Skutki prawne zaciągania przez samorządy terytorialne kredytów konsolidacyjnych w świetle obowiązujących regulacji ustawy o finansach publicznych wraz $\mathrm{z}$ oceną możliwości dokonania zmian $\mathrm{w}$ tym zakresie $\ldots \ldots \ldots \ldots$

\section{Irena Galińska-Rączy}

Ocena petycji Andrzeja Halickiego w sprawie nowelizacji ustawy o petycjach w zakresie zamieszczania odpowiedzi na petycję na stronie internetowej podmiotu rozpatrującego petycję oraz zmiany terminu przekazania petycji podmiotowi właściwemu do jej rozpatrzenia $\ldots \ldots \ldots \ldots \ldots \ldots$

\section{Krzysztof Skotnicki}

Niepołączalność stanowisk członków organów jednostek pomocniczych w gminach . . . . . . . . . . . . . . . . . . . . . .

\section{STANOWISKA SEJMU W SPRAWACH PRZED TRYBUNAŁEM KONSTYTUCYJNYM}

\section{Marcin Spyra}

Ocena zgodności z Konstytucją art. $767^{3 a}$ Kodeksu postępowania cywilnego $\mathrm{w}$ zakresie, $\mathrm{w}$ jakim nie przewiduje skargi na orzeczenie referendarza $\mathrm{w}$ przedmiocie skargi na czynności komornika sądowego . . . . . . . . . . . .

\section{Andrzej Herbet}

Ocena zgodności z Konstytucją art. $173 \$ 1$ ustawy - Prawo o postępowaniu przed sądami administracyjnymi w zakresie braku możliwości zaskarżenia skargą kasacyjną postanowienia Naczelnego Sądu Administracyjnego odrzucającego skargę o wznowienie postępowania przed Naczelnym Sądem Administracyj-

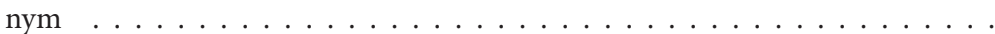




\section{CONTENTS}

1 ARTICLES

Agnieszka Laskowska-Hulisz

Immunity of the State in court examination of civil law cases - selected proce-

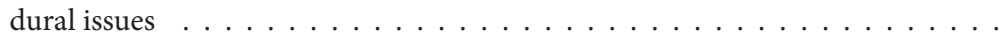

Krzysztof Kozłowski

Duty of care for veterans of the struggles for independence of the Polish State -

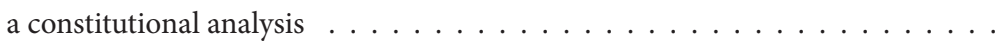

\section{OPINIONS OF THE BUREAU OF RESEARCH (BAS)}

A CONSTITUTIONAL LAW ISSUES

\section{Piotr Chybalski}

Interpretation of the Article 47 para. 2 subpara. 1 of the Standing Orders of the Sejm - the procedure for considering amendments in committees . . . . . . .

\section{Wojciech Odrowąż-Sypniewski}

Interpretation of Article 152 para. 5 of the Standing Orders of the Sejm - notification to committee members about a committee sitting . . . . . . . . .

\section{Ewelina Gierach}

Application of provisions of the Code of Administrative Procedure by the Sejm

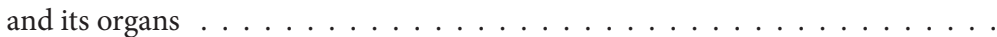

\section{Wojciech Odrowąż-Sypniewski}

Interpretation of Article 23 para. 2 of the Standing Orders of the Sejm - an appeal against a resolution of the Presidium of the Sejm on decreasing the salary of a Deputy or parliamentary per diem allowance $\ldots \ldots \ldots \ldots$

B EUROPEAN AND INTERNATIONAL LAW ISSUES

\section{Cezary Mik}

Analysis of the degree of implementation of provisions of the conventions on stateless persons of 1954 and 1961 in the Polish legal system . . . . . . . .

\section{Zofia Szpringer, Ziemowit Cieślik}

Draft General Budget of the European Union for the financial year 2019 - General introduction - General statement of revenue - Statement of revenue and expenditure by section $\ldots \ldots \ldots \ldots \ldots \ldots \ldots$

C LEGISLATIVE OPINIONS

\section{Paweł Bachmat}

Criminal Liability referred to in article 55a paragraphs 1-2 and its exclusion ("kontratyp") article 55a paragraphs 3 of the Act on the Institute of National Remembrance - Commission for the Prosecution of Crimes against the Polish Nation . .

\section{Beata Bińkowska-Artowicz}

Possibility of introducing regulations admitting hunting with a bow into the Hunting Law 


\section{Rafał Dubowski}

Partnership or marriage? Evaluation of Deputies' Bills - on Partnership and Introductory Provisions of the Act on Partnership . . . . . . . . . . . .

D DEPUTIES' AFFAIR

\section{Irena Galińska-Rączy}

Limitation period for the right to retirement gratuity mentioned in Article 38 of the Act on the Exercise of the Mandate of a Deputy or Senator . . . . . . .

Wojciech Odrowąż-Sypniewski

The right of a Deputy who is deprived of liberty to receive a parliamentary per diem allowance and a Deputy's salary $\ldots \ldots \ldots \ldots \ldots$

E MISCELLANEA

\section{Irena Galińska-Rączy}

Submitting by a government administration body - under the Act on Access to Public Information - correspondence regarding a Deputy's intervention to a communal body being an addressee of the intervention . . . . . . . .

\section{Henryk Dzwonkowski}

Legal effects of contracting consolidation credits by local self-governments in the light of current provisions of the Act on Public Finances, along with an assessment of the possibility of future changes in this respect $\ldots \ldots \ldots \ldots$

\section{Irena Galińska-Rączy}

Assessment of Andrzej Halicki's petition concerning amendment of the Act on Petitions as regards publishing a reply to a petition on a website of a respective entity and modifying deadline for transferring petition to a competent entity . .

\section{Krzysztof Skotnicki}

Incompatibility of positions in auxiliary units of communes $\ldots \ldots \ldots \ldots$

\section{THE SEJM'S POSITIONS ON CASES} BEFORE THE CONSTITUTIONAL TRIBUNAL

\section{Marcin Spyra}

Assessment of conformity to the Constitution of Article $767^{3 a}$ of the Code of Civil Procedure as regards the lack of possibility to appeal against a court referendary's decision regarding complaint regarding bailiff's activities . . . . . . . .

\section{Andrzej Herbet}

Assessment of conformity to the Constitution of Article 173 para. 1 of the Law on Proceedings Before Administrative Courts as regards the lack of possibility to lodge a cassation appeal against the Supreme Administrative Court's order on rejection of the claim for reopening of the proceedings before the Supreme Administrative Court (SAC) . . . . . . . . . . . . . . . . . . 


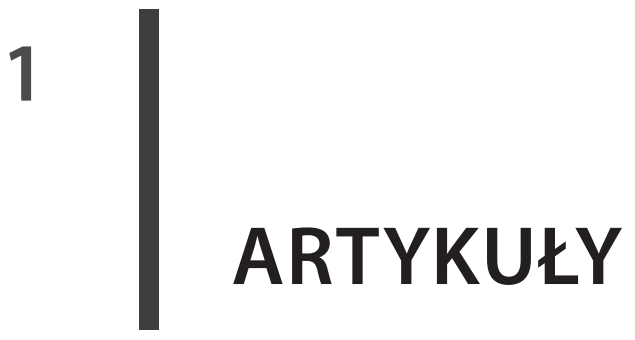





\title{
Immunitet państwa w postępowaniu rozpoznawczym w sprawach cywilnych - wybrane zagadnienia procesowe
}

\begin{abstract}
Immunity of the State in court examination of civil law cases - selected procedural issues: A dominant view that a foreign state uses immunity in court examination of civil law cases deserves acceptance. This is the so-called limited immunity. The immunity of a foreign state in court examination of civil law cases and matters related to its examination should not be regulated in domestic law, including the Code of the Civil Procedure. Solutions for pursuing claims before national courts from a foreign state cannot be limited only to the issue of regulation of state immunity and the possibility of its waiving by the foreign state, but they also should cover issues related to the subsequent execution of a judgement delivered in such proceedings.
\end{abstract}

Keywords: civil procedure law, state immunity

Słowa kluczowe: prawo postępowania cywilnego, immunitet państwa

Doktor nauk prawnych, adiunkt w Katedrze Prawa i Postępowania Cywilnego Uniwersytetu Mikołaja Kopernika w Toruniu; agnieszka.laskowska@umk.pl.

\section{Uwagi wstępne}

W Kodeksie postępowania cywilnego ${ }^{1}$ nie ma regulacji, która wprost odnosiłaby się do immunitetu państwa obcego w postępowaniu rozpoznawczym w sprawach cywilnych. W literaturze przedmiotu nie budzi jednak wątpliwości, że państwo obce korzysta $\mathrm{z}$ takiego immunitetu $\mathrm{w}$ postępowaniu cywilnym ${ }^{2}$. Sporne jest natomiast m.in. to, na jakiej podstawie państwo obce korzysta $\mathrm{z}$ tego immu-

1 Ustawa z 17 listopada 1964 r. - Kodeks postępowania cywilnego, t.j. Dz.U. 2018, poz. 1360 , ze zm.; dalej: k.p.c.

2 W polskiej literaturze prawniczej problematyka immunitetu państwa została przeanalizowana w sposób niezwykle wnikliwy przez P. Grzegorczyka w pracy zatytułowanej Immunitet państwa w postępowaniu cywilnym, Warszawa 2010, a także przez J. Sutora, Immunitet państwa, Warszawa 2011. 
nitetu, a także to, w jakim zakresie należy do immunitetu państwa stosować przepisy Kodeksu postępowania cywilnego dotyczące immunitetu sądowego, w tym w szczególności dotyczące zrzeczenia się tego immunitetu. Na tym tle powstaje też pytanie, jak należy zakwalifikować immunitet państwa, a także czy należy go wiązać z jurysdykcją krajową.

Problematyka ta stała się niezwykle aktualna zwłaszcza w ostatnich latach w związku z pozwami składanymi w sądach polskich przez obywateli polskich przeciwko państwu niemieckiemu o odszkodowania za szkody wyrządzone podczas II wojny światowej. Zresztą problem dopuszczalności dochodzenia przed sądami krajowymi odszkodowań za szkody wyrządzone podczas II wojny światowej nie pojawił się tylko w polskich sądach ${ }^{3}$.

Z tych względów warto krótko przedstawić zagadnienie immunitetu państwa występującego w roli strony pozwanej w procesie cywilnym (uczestnika postępowania nieprocesowego ${ }^{4}$ ) oraz możliwości powołania się na ten immunitet i konsekwencji z tym związanych, jak również dopuszczalności zrzeczenia się przez państwo obce przysługującego mu immunitetu. Niniejszy artykuł stanowi zatem próbę przedstawienia kluczowych kwestii związanych z immunitetem państwa w postępowaniu cywilnym oraz wyłaniających się na ich tle problemów, nie aspiruje natomiast do wyczerpującego omówienia złożonej problematyki tego immunitetu, która została już kompleksowo i monograficznie opracowana w polskiej literaturze prawniczej.

\section{Podstawy prawne immunitetu państwa}

W literaturze polskiej dominuje pogląd, według którego państwo obce korzysta w postępowaniu cywilnym z immunitetu państwa, chociaż na kanwie wydanych $\mathrm{w}$ tym przedmiocie orzeczeń stawiane są też pytania, czy immunitet jurysdykcyjny państwa może być przez nie skutecznie powoływany przed sądem krajowym innego państwa w stosunku do aktów uznawanych za sprzeczne z prawem

3 Zob. np. E. Olas, Immunitet jurysdykcyjny państwa w wybranych orzeczeniach sądów krajowych, „Problemy Współczesnego Prawa Międzynarodowego, Europejskiego i Porównawczego" 2017, t. X, s. 48 i n., a także J. Sutor, Immunitet państwa i immunitet dyplomatyczny a ściganie i karanie zbrodni o charakterze międzynarodowym w świetle statutu rzymskiego, „Przegląd Sądowy” 2017, nr 11/12, s. 94 i n. Zob. np. skargę Republiki Federalnej Niemiec z 23 grudnia 2008 r. złożoną przeciwko Republice Włoskiej do Międzynarodowego Trybunału Sprawiedliwości, https://www.icj-cij.org.

4 W dalszej części artykułu będę pisać o pozwanym oraz pozwie. Uwagi te należy jednak odpowiednio odnieść także do uczestnika postępowania nieprocesowego oraz wniosku o wszczęcie postępowania nieprocesowego. 
międzynarodowym ${ }^{5}$. Ponadto wśród zwolenników poglądu, że państwo obce korzysta w postępowaniu cywilnym z immunitetu państwa, sporne jest, na jakiej podstawie państwo obce korzysta $\mathrm{z}$ immunitetu w postępowaniu prowadzonym przed sądami innego państwa. W odpowiedzi na tak postawione pytanie w literaturze powołuje się m.in. art. $1111 \S 1$ pkt 3 k.p.c. lub też odsyła do art. 9 Konstytucji RP statuującego dyrektywę interpretacji przyjaznej prawu międzynarodowemu i przyjęciu w konsekwencji, że źródłem takiego immunitetu jest powszechnie przyjęty zwyczaj międzynarodowy ${ }^{6}$. Sąd Najwyższy podziela drugi z przedstawionych poglądów i przyjmuje, że państwu obcemu przysługuje immunitet jurysdykcyjny w postępowaniu cywilnym. Źródłem tego immunitetu jest powszechnie przyjęty zwyczaj międzynarodowy ${ }^{7}$. Pogląd ten jest zbieżny ze stanowiskiem orzecznictwa sądów wielu państw (np. Wielkiej Brytanii, Włoch, Szwajcarii, Grecji, Niemiec), a także Europejskiego Trybunału Praw Człowieka ${ }^{8}$. U podstaw immunitetu jurysdykcyjnego państw obcych leży zasada równości państw (par in parem non habet imperium); jest on wyrazem poszanowania suwerenności państw i zmierza do utrzymania między państwami przyjaznych stosunków .

Obecnie dominuje pogląd, według którego immunitet przysługujący państwu obcemu w postępowaniu cywilnym jest tzw. immunitetem ograniczonym (funkcjonalnym), tj. przysługującym mu w sprawach związanych $\mathrm{z}$ władczą działalnością (acta iure imperii), nie obejmuje on natomiast spraw związanych z udziałem przez państwo w zwykłym obrocie cywilnym lub gospodarczym (acta iure gestionis $)^{10}$. Taki charakter tego immunitetu wynika w państwach prawa konty-

5 Zob. np. A. Jakubowski, Immunitet państwa. Ius cogens a ochrona dziedzictwa kultury - uwagi krytyczne w świetle wyroku MTS z 3.2.2012 r., Niemcy v. Włochy, „Kwartalnik Prawa Publicznego" 2012, t. XII, nr 4, s. 55 i n.

6 Bliżej P. Grzegorczyk, Immunitet, op. cit., s. 210 i n., oraz powołana tam literatura. Zob. także m.in. E. Wengerek, Immunitet egzekucyjny państw obcych, „Studia Prawnicze" 1967, nr 17, s. 138; A. Wyrozumska, Polskie sądy wobec immunitetu państwa obcego, „Państwo i Prawo” 2000, z. 3, s. 28 i n.; J. Sutor, Immunitet dyplomatyczny i immunitet państwa, „Przegląd Sądowy” 2008, nr 4; M. Wasiński, Immunitet państwa a jurysdykcja terytorialna (na tle orzeczenia SN w sprawie Natoniewski v. RFN), „Państwo i Prawo" 2012, z. 10, s. 76 i n. W mojej ocenie trafny jest drugi z zaprezentowanych poglądów.

7 SN w postanowieniu z 29 października 2010 r., sygn. akt IV CSK 465/09, OSNC 2010, nr 2, poz. 22.

8 Zob. np. wyrok Trybunału z 21 listopada 2001 r. w sprawie Al-Adsani v. Zjednoczone Królestwo, sygn. akt 35763/97, §54, ECHR 2001-XI.

9 Ibidem.

10 Jeżeli chodzi o prawo polskie, zob. np. SN w postanowieniu z 13 sierpnia 2008 r., sygn. akt III CSK 293/07, OSNC - Zb. dodatkowy 2009, nr B, poz. 33, s. 1; SN w postanowieniu z 29 października2010 r., sygn. akt IV CSK 465/09, OSNC 2010, nr 2, poz. 22. Warto również przywołać postanowienie SN z 11 stycznia 2000 r., sygn. akt 
nentalnego z orzecznictwa sądowego w odróżnieniu od państw systemu common law (np. Stany Zjednoczone, Wielka Brytania), które wprowadziły w tym zakresie stosowne regulacje prawne ${ }^{11}$.

Przesądzenie kwestii dopuszczalności korzystania przez państwo obce z immunitetu sądowego w postępowaniu cywilnym, wymaga następnie wskazania, jakie przepisy mają do niego zastosowanie. W literaturze trafnie wskazuje się, że reżim procesowy immunitetu państwa powinien być określony na podstawie przepisów Kodeksu postępowania cywilnego o immunitecie sądowym i egzekucyjnym, z tym że w zależności od przyjętej podstawy prawnej dla immunitetu państwa jedni autorzy przyjmują, że przepisy te mają zastosowanie wprost, inni - że w drodze analogii lub odpowiednie ${ }^{12}$. Co oznacza, że do immunitetu państwa w postępowaniu cywilnym ma zastosowanie m.in. art. 1113 i art. 1114 k.p.c. W mojej ocenie przepisy te mają zastosowanie w drodze analogii, z uwagi na brak regulacji immunitetu państwa w Kodeksie postępowania cywilnego. Stosowanie powołanych przepisów wprost lub odpowiednio byłoby możliwe tylko wtedy, gdyby ustawodawca uregulował immunitet państwa w przepisach krajowych i w zakresie nieuregulowanym w tych przepisach odsyłał do stosowania do niego wprost lub odpowiednio przepisów o immunitecie sądowym lub egzekucyjnym.

W prawie polskim immunitet państwa nie jest regulowany przepisami krajowymi innych państw europejskich, podobnie jak m.in. w prawie austriackim, francuskim, niemieckim czy szwajcarskim. Jest on zaliczany do samodzielnej, bezwzględnej przesłanki procesowej, jaką jest jurysdykcja. Istnienie immunitetu państwa stanowi przeszkodę do merytorycznego rozpoznania sprawy i powinno

I PKN 562/99, OSNAPiUS 2000, nr 19, poz. 723, z glosą J. Ciszewskiego, OSP 2000, nr 11. W ostatnio wskazanym postanowieniu SN postawił tezę: Polskim sądom pracy przysługuje jurysdykcja krajowa w sprawie z powództwa obywatela polskiego przeciwko ambasadzie państwa obcego o uznanie bezskuteczności wypowiedzenia umowy o pracę (przywrócenie do pracy). Przepis art. $1114 \$ 1$ pkt 1 KPC [Kodeksu postępowania cywilnego - dopisek A.L.-H.] dotyczy immunitetu przedstawiciela dyplomatycznego a nie immunitetu państwa obcego. Ambasadzie jako pracodawcy nie stuży immunitet przysługujacy państwu. Do lat 50. ubiegłego wieku przyznawano państwu obcemu immunitet absolutny (pełny), który przysługiwał we wszystkich sprawach niezależnie od ich charakteru (zob. np. W. Siedlecki, Powództwo obcego państwa i przeciw obcemu państwu przed sądami polskimi, „Palestra” 1936, nr 5, s. 451). Koncepcja takiego immunitetu znalazła swój wyraz w uchwale składu siedmiu sędziów SN z 26 września 1990 r., sygn. akt III PZP 9/90, OSNC 1991, nr 2-3, poz. 17. Por. K. Gruszczyński, Czy Niemcy moga być pozywane w Polsce w świetle wyroku Sądu Najwyższego z 2010 r.?, "Studia Prawnicze i Administracyjne” 2012, nr 2(4), s. 69. Zob. też np. E. Olas, Immunitet jurysdykcyjny, op. cit., s. 48-49.

12 P. Grzegorczyk, Immunitet, op. cit., s. 261 i n. Na temat analogii w prawie procesowym zob. M. Walasik, Analogia w prawie procesowym cywilnym, Warszawa 2013, s. 253 i n. 
prowadzić do odmowy jej rozpoznania. Sąd bada istnienie tej przesłanki z urzę$\mathrm{du}^{13} . \mathrm{Z}$ analizy wybranych orzeczeń sądów krajowych innych państw europejskich, m.in. niemieckich, włoskich, greckich, wynika, że fakt istnienia ograniczonego immunitetu państwa w postępowaniu cywilnym nie jest kwestionowany, podobnie jak prawo do jego zrzeczenia się. Przyjmuje się przy tym, że zrzeczenie się immunitetu państwa może nastąpić także w sposób dorozumiany ${ }^{14}$. Sądy krajowe różnie jednak interpretują tzw. dorozumiane zrzeczenie się immunitetu.

\section{Immunitet państwa a jurysdykcja krajowa}

Na tle immunitetu państwa powstaje również pytanie o stosunek immunitetu państwa do jurysdykcji krajowej. Od nowelizacji przepisów Kodeksu postępowania cywilnego z $2008 \mathrm{r}^{15}$ wyznaczenie granic kompetencji sądów polskich w stosunkach z zagranicą następuje na dwóch poziomach: władzy jurysdykcyjnej, której ustawowa regulacja sprowadza się do immunitetu sądowego i egzekucyjnego, oraz jurysdykcji krajowej. Są to dwie niezależne przesłanki procesowe, które należy rozpatrywać oddzielnie, z tym że stwierdzenie istnienia immunitetu wyłącza możliwość badania przesłanki jurysdykcji krajowej. Badanie przesłanki jurysdykcji krajowej może mieć miejsce tylko wtedy, gdy mamy do czynienia $\mathrm{z}$ takimi stronami procesu cywilnego (uczestnikami postępowania nieprocesowego), co do których nie ma wątpliwości, że nie korzystają z immunitetu, czyli mogą podlegać polskiej władzy jurysdykcyjnej. Immunitet państwa należy do przesłanki władzy jurysdykcyjnej, co wynika z prawa międzynarodowego, w odniesieniu do Polski zwyczaju międzynarodowego (nie ratyfikowaliśmy żadnej umowy, która regulowałaby kwestie immunitetu państwa) ${ }^{16}$. Przepisy o immunitecie sądowym stosuje się do niego przez analogię. Istnienie immunitetu państwa oznacza, że państwo, któremu on przysługuje (a przysługuje na mocy zwyczaju międzynarodowego każdemu państwu obcemu w sferze imperium), nie podlega władzy jurysdykcyjnej innego państwa, w związku z tym problem jurysdykcji krajowej w ogóle nie powstaje. Skoro bowiem nie ma władzy jurysdykcyjnej, to

13 Bliżej P. Grzegorczyk, Immunitet, op. cit., s. 239 i n., oraz powołana tam literatura. Zob. też, jeżeli chodzi o: prawo austriackie, np. W.H. Rechberger, D.A. Simotta, Grundriss des österreichischen Zivilprozessrechts. Erkenntnisverfahren, Wien 2010, s. 30-31; prawo francuskie, np. S. Guinchard i in., Droit processuel. Droit commun et droit comparé du procès, Paris 2005, s. 596-597; prawo niemieckie, np. O. Jauering, Zivilprozessrecht, München 2003, s. 20 i n.; Ch.G. Paulus, Zivilprozessrecht. Erkenntnisverfahren, Zwangvollstreckung und Europäisches Zivilprozessrecht, Berlin 2010, s. 11.

14 E. Olas, Immunitet jurysdykcyjny, op. cit., s. 52 i n.

15 Ustawa z 5 grudnia 2008 r. o zmianie ustawy - Kodeks postępowania cywilnego oraz niektórych innych ustaw, Dz.U. nr 234, poz. 1571. Weszła w życie 1 lipca 2009 r.

16 Zob. też P. Grzegorczyk, Immunitet, op. cit., s. 79 i n. 
nie można przejść do badania kolejnej przesłanki procesowej w postaci istnienia w sprawie jurysdykcji krajowej. Brak władzy jurysdykcyjnej w sprawie wniesionej przeciwko państwu obcemu nie wynika zatem z krajowych przepisów o jurysdykcji krajowej, ale ze zwyczaju międzynarodowego, na podstawie którego honoruje się w Polsce, podobnie jak w całej społeczności międzynarodowej, immunitet państwa (ograniczony).

\section{Immunitet państwa jako przesłanka procesowa}

Na podstawie art. 1113 k.p.c. immunitet sądowy sąd bierze pod rozwagę z urzędu w każdym stanie sprawy. W razie stwierdzenia istnienia immunitetu sąd odrzuca pozew albo wniosek. Rozpoznanie sprawy z naruszeniem immunitetu sądowego powoduje nieważność postępowania. Jeżeli osoba, przeciwko której albo z udziałem której wszczęto sprawę, uzyska immunitet sądowy w toku postępowania, sąd umarza postępowanie. Stosując ten przepis w drodze analogii do immunitetu państwa, należy na wstępie podkreślić, że w literaturze ${ }^{17}$ panuje zgodność co do tego, że immunitet sądowy jest jedną z bezwzględnych przesłanek procesowych ujemnych (przeszkodą procesową), którą sąd powinien badać z urzędu na każdym etapie postępowania i w każdym stanie sprawy. Pogląd ten odnosi się również do immunitetu państwa. Korzystanie przez pozwane państwo obce z immunitetu państwa stanowi bowiem przeszkodę do rozpoznania sprawy przez sąd polski, natomiast nieistnienie tej przesłanki, wprost przeciwnie, umożliwia merytoryczne rozpoznanie sprawy. W razie stwierdzenia istnienia immunitetu państwa, sąd powinien pozew albo wniosek odrzucić. W przepisie tym nie wskazano terminu na uwzględnienie faktu istnienia immunitetu państwa przez sąd, lecz wprost przeciwnie, ustawodawca wprowadził zasadę, że sąd bierze go pod rozwagę z urzędu w każdym stanie sprawy. Jeżeli zatem pozwane państwo obce, któremu przysługuje immunitet państwa, podobnie zresztą jak inne podmioty korzystające z immunitetów sądowych, ma prawo się go zrzec, to sąd nie powinien odrzucać pozwu z urzędu przed doręczeniem jego odpisu pozwanemu państwu obcemu. Pogląd ten podziela Sąd Najwyższy, który w uzasadnieniu postanowienia z 29 października 2010 r. ${ }^{18}$ stwierdził: Należy podzielić wyrażany w piśmiennictwie pogląd, że ze względu na przysługiwanie państwu immunitetu jurysdykcyjnego nie jest wykluczone - w świetle właściwego w tym względzie prawa międzynarodowego publicznego - doręczenie państwu odpisu pozwu. Sąd orzeka-

17 Zob. m.in. K. Weitz, Jurysdykcja krajowa w postępowaniu cywilnym, Warszawa 2005, s. 93; P. Grzegorczyk, Immunitet, op. cit., s. 303; T. Misiuk-Jodłowska (w aktualizacji K. Weitz) [w:] J. Lapierre i in., Postepowanie cywilne, Warszawa 2016, s. 71; K. Weitz [w:] J. Lapierre i in., Postępowanie cywilne, Warszawa 2016, s. 648.

Sygn. akt IV CSK 465/09, OSNC 2010, nr 2, poz. 22. 
jący w sprawie nie jest bowiem uprawniony do decydowania $\mathrm{z}$ urzędu za pozwane państwo obce o tym, czy będzie ono korzystać z immunitetu czy też nie. Na marginesie należy zauważyć, że pogląd o celowości odrzucenia pozwu dopiero po doręczeniu jego odpisu pozwanemu z powodu wystąpienia przeszkody procesowej znajduje swoje uzasadnienie także w odniesieniu do innych przesłanek procesowych, jak np. jurysdykcji krajowej, która może też wynikać $\mathrm{z}$ wdania się przez pozwanego $\mathrm{w}$ spór ${ }^{19}$, czy zapisu na sąd polubowny ${ }^{20}$. Odrzucenie zatem w takim wypadku pozwu przed doręczeniem jego odpisu pozwanemu i umożliwieniu mu zajęcia stanowiska $\mathrm{w}$ sprawie byłoby działaniem przedwczesnym, stanowiącym nadmierny formalizm, prowadzący $\mathrm{w}$ istocie do utrudnienia powodowi dochodzenia przysługujących mu praw przed sądem.

Przepis art. 1113 k.p.c. nie nakłada bowiem na sąd obowiązku odrzucenia pozwu/wniosku o wszczęcie postępowania nieprocesowego niezwłocznie po jego wniesieniu do sądu, lecz wprost przeciwnie, pozostawia do decyzji sądu to, na jakim etapie postępowania odrzuci pozew/wniosek. Rozstrzygnięcie sądu w tym zakresie powinno być oparte na rozważeniu okoliczności sprawy oraz stanowiska stron, skoro od woli strony pozwanej ustawodawca uzależnił możliwość rozpoznania sprawy, w której strona ta korzysta z immunitetu. Dodatkowo należy zauważyć, że sąd, odrzucając pozew z powodu wystąpienia przeszkody procesowej w postaci immunitetu państwa dopiero po doręczeniu odpisu pozwu pozwanemu państwu obcemu i zajęciu przez nie w tej kwestii stanowiska lub ewentualnym milczeniu, które nie może co do zasady być równoznaczne ze zrzeczeniem się immunitetu, nie popełnia żadnego uchybienia procesowego.

Jeżeli jednak sąd odrzuciłby pozew, powołując się na immunitet pozwanego państwa obcego przed doręczeniem mu odpisu pozwu na posiedzeniu niejawnym, co nie stanowi uchybienia procesowego, powinien doręczyć temu państwu postanowienie o odrzuceniu pozwu. Stosownie bowiem do treści art. $357 \$ 2$ w związku z art. $13 \$ 2$ k.p.c. postanowienie wydane na posiedzeniu niejawnym sąd doręcza z urzędu obu stronom, chyba że przepis szczególny stanowi inaczej.

19 Zob. np. art. 26 ust. 1 rozporządzenia Parlamentu Europejskiego i Rady (UE) nr 1215/2012 z 12 grudnia 2012 r. w sprawie jurysdykcji i uznawania orzeczeń sądowych oraz ich wykonywania w sprawach cywilnych i handlowych, Dz.Urz. UE 2012 L 351, s. 1: Jeżeli sąd państwa członkowskiego nie ma jurysdykcji na podstawie innych przepisów niniejszego rozporządzenia, uzyskuje on jurysdykcję, jeżeli pozwany przed tym sądem wda się w spór. Niniejszy przepis nie ma zastosowania, jeżeli pozwany wdaje się w spór w tym celu, aby podnieść zarzut braku jurysdykcji lub jeżeli inny sąd ma na podstawie art. 24 jurysdykcje wyłaczną.

20 Stosownie do treści art. $1165 \$ 1$ k.p.c.: $W$ razie wniesienia do sądu sprawy dotyczacej sporu objętego zapisem na sąd polubowny, sąd odrzuca pozew lub wniosek o wszczęcie postępowania nieprocesowego, jeżeli pozwany albo uczestnik postępowania nieprocesowego podniósł zarzut zapisu na sąd polubowny przed wdaniem się w spór co do istoty sprawy. 
Z uwagi na to, że postanowienie to jest zaskarżalne, sąd powinien je doręczyć $\mathrm{z}$ uzasadnieniem oraz pouczeniem o dopuszczalności wniesienia środka zaskarżenia, terminie i sposobie jego wniesienia ${ }^{21}$. W takim wypadku pozwane państwo obce, któremu przysługuje w sprawie immunitetu jurysdykcyjny, może zrzec się tego immunitetu $\mathrm{w}$ zażaleniu na postanowienie o odrzuceniu pozwu. Trudno jednak sobie wyobrazić sytuację, w której pozwane państwo obce zaskarżyłoby postanowienie dla siebie korzystne.

Dodatkowo należy podkreślić, że immunitet państwa jest tylko jedną z bezwzględnych przesłanek procesowych, które sąd powinien badać z urzędu na każdym etapie postępowania (zob. art. 199 w związku z art. 202 w związku z art. 13 $\$ 2$ k.p.c.). Nie można zatem wykluczyć takich sytuacji, w których sąd odrzuci pozew z powodu np. niedopuszczalności drogi sądowej czy braku zdolności sądowej powoda będącego osobą fizyczną jeszcze przed doręczeniem jego odpisu pozwanemu. We wskazanych bowiem wypadkach postępowanie cywilne i tak nie mogłoby się toczyć, niezależnie od stanowiska pozwanego państwa obcego w przedmiocie immunitetu państwa. Jeżeli zatem w sprawie wystąpi inna przeszkoda procesowa, której nie można skonwalidować ani nie zależy ona od woli pozwanego, sąd powinien odrzucić pozew, nie czekając na stanowisko pozwanego. Katalog przyczyn odrzucenia pozwu jest zamknięty i uregulowany w art. 199, $1099,1113,1124 \$ 3$ oraz $1165 \$ 1$ k.p.c. W odniesieniu do niektórych z tych przyczyn, mimo braku wyraźnej regulacji, z treści przepisu należy jednak wyprowadzić wniosek, kiedy sąd powinien najwcześniej odrzucić pozew. Decyzja w tym zakresie każdorazowo należy jednak do sądu pierwszej instancji i może być podyktowana różnymi względami, w tym związanymi z prawidłowym stosowaniem przez sądy przepisów prawa ${ }^{22}$.

\section{Zrzeczenie się przez państwo obce immunitetu państwa}

Stosownie do treści art. $1114 \$ 1$ k.p.c. przepisy art. $1111 \$ 1$ i art. $1112 \$ 1$ nie mają zastosowania, jeżeli państwo wysyłające w sposób wyraźny zrzeknie się immunitetu sądowego w stosunku do osób wymienionych w tych przepisach. Stosując ten przepis w drodze analogii do pozwanego państwa obcego, korzystającego $\mathrm{z}$ immunitetu państwa, należy stwierdzić, że pozwane państwo obce, któremu

${ }^{21}$ Tak też SN w uchwale z 28 marca 1955 r., sygn. akt I CO 18/55, OSNCK 1955, nr 4, poz. 66.

22 Jeżeli chodzi o praktykę sądów zagranicznych, to jest ona różna i trudno tu o jakiekolwiek uogólnienia. Jedne sądy powołują się w sprawie o odszkodowanie za szkody wyrządzone podczas wojny i związane z naruszeniem praw człowieka na uchylenie immunitetu pozwanego państwa obcego z powodu naruszenia przez to państwo norm iuris cogentis i przystępują do rozpoznania sprawy, inne wprost przeciwnie, zob. E. Olas, Immunitet jurysdykcyjny, op. cit., s. 48 i n. 
taki immunitet przysługuje, może się go zrzec na podstawie art. $1114 \$ 1$ k.p.c. stosowanego przez analogię. Prawo państwa obcego do zrzeczenia się immunitetu państwa jest powszechnie akceptowane, nie tylko w literaturze polskiej, ale także zagranicznej ${ }^{23}$. Prawo takie zostało również przewidziane m.in. w art. 1-3 Konwencji europejskiej o immunitecie państwa sporządzonej w Bazylei 16 maja 1972 r. ${ }^{24}$ oraz w art. 7-9 Konwencji Narodów Zjednoczonych z 2 grudnia 2004 r. o immunitecie jurysdykcyjnym państw i ich mieniu ${ }^{25}$. Powszechnie przyjmuje się, że państwo jako beneficjent immunitetu może się go zrzec w całości lub części, z tych względów immunitet państwa traktowany jest jako ius dispositivum ${ }^{26}$.

Zrzeczenie się immunitetu dla swej skuteczności powinno spełniać następujące warunki:

- powinno być wyraźne, co oznacza, że pozwane państwo obce powinno złożyć stosowne oświadczenie o zrzeczeniu się immunitetu, lub dorozumiane ${ }^{27}$, z tym że zrzeczenie się dorozumiane immunitetu powinno wynikać z zachowania państwa obcego ocenianego w świetle okoliczności sprawy, np. państwo to wdało się w spór, nie powołując się na istnienie immunitetu państwa, albo wytoczyło powództwo wzajemne,

- zrzeczenie się może dotyczyć tylko immunitetu przysługującego pozwanemu państwu obcemu w stosunku do powoda, czyli w danej konkretnej sprawie,

- jeżeli państwo obce zrzeka się immunitetu po wszczęciu przeciwko niemu procesu cywilnego, składając oświadczenie, to oświadczenie o zrzeczeniu się immunitetu może być zawarte w piśmie procesowym składanym w sądzie, do którego sprawa została wniesiona, ewentualnie na posiedzeniu wyznaczonym na rozprawę przez ustne oświadczenie złożone przez umocowanego przedstawiciela tego państwa do protokołu rozprawy; oświadczenie takie może być też złożone drogą dyplomatyczną,

- oświadczenie o zrzeczeniu się immunitetu w imieniu pozwanego państwa obcego powinna złożyć osoba umocowana do składania tego rodzaju oświadczeń w imieniu danego państwa.

W art. $1114 \$ 1$ k.p.c. ustawodawca nie wskazał terminu, w którym oświadczenie takie może być złożone, co oznacza, że może być ono złożone od chwili wszczęcia postępowania cywilnego w sprawie do chwili jego prawomocnego zakończenia, na każdym etapie postępowania. Zrzec się immunitetu państwo obce może również przed wniesieniem przeciwko niemu pozwu. W takim wypadku

23 Zob. P. Grzegorczyk, Immunitet, op. cit., s. 194-196, oraz powołana tam literatura.

24 Polska nie jest stroną tej Konwencji.

25 Konwencja ta nie weszła w życie.

26 Państwo obce mogło się zrzec także immunitetu absolutnego.

27 Taki sposób zrzeczenia się immunitetu państwa jest powszechnie akceptowany przez sądy innych państw, zob. E. Olas, Immunitet jurysdykcyjny, op. cit., s. 52 i n. 
zrzeczenie się powinno dotyczyć konkretnej sprawy i mieć formę oświadczenia złożonego na piśmie przez uprawnionego przedstawiciela państwa zrzekającego się immunitetu. Oświadczenie powinno być przesłane drogą dyplomatyczną. Należy jednak podkreślić, że jeżeli pozwane państwo obce, któremu przysługuje w sprawie immunitet, nie zrzeknie się go najpóźniej po doręczeniu mu odpisu pozwu, to sąd pierwszej instancji powinien pozew odrzucić postanowieniem na podstawie art. 1113 k.p.c. Postanowienie takie jako kończące postępowanie w sprawie jest zaskarżalne zażaleniem (art. $394 \$ 1$ k.p.c.), w wypadku zaś jego niezaskarżenia i upływu terminu do wniesienia zażalenia lub wydania wskutek wniesienia zażalenia postanowienia przez sąd drugiej instancji oddalającego zażalenie i w konsekwencji utrzymującego w mocy postanowienie o odrzuceniu pozwu, postępowanie w sprawie kończy się prawomocnym orzeczeniem (czyli prawomocnym postanowieniem sądu pierwszej instancji o odrzuceniu pozwu albo prawomocnym postanowieniem sądu drugiej instancji oddalającym zażalenie). Gdyby zaś sąd nie odrzucił pozwu z powodu immunitetu państwa i przystąpił do rozpoznania sprawy przeciwko pozwanemu państwu obcemu, państwo to nadal ma prawo zrzec się przysługującego mu immunitetu. Natomiast postępowanie prowadzone przez sąd polski dotknięte będzie kwalifikowanym uchybieniem procesowym prowadzącym do nieważności postępowania. Nieważność postępowania wymaga jednak stwierdzenia przez sąd drugiej instancji, co z kolei możliwe jest w postępowaniu apelacyjnym, które może być wywołane wniesieniem apelacji. Pozwane państwo obce, któremu przysługuje immunitet państwa, którego się nie zrzekło w toku postępowania, może podnieść to uchybienie w zasadzie dopiero w apelacji wnoszonej od wydanego w sprawie orzeczenia (wyroku lub postanowienia co do istoty sprawy wydanego w postępowaniu nieprocesowym) lub zażaleniu w wypadku umorzenia postępowania. Niezaskarżenie zaś orzeczenia wydanego przeciwko państwu obcemu, któremu przysługuje w sprawie immunitet państwa i które się tego immunitetu nie zrzekło w postępowaniu, ma ten skutek, że orzeczenie takie staje się prawomocne, ważne i skuteczne. Oczywiście orzeczenie takie może być uchylone wskutek wniesienia jednego ze środków zaskarżenia prawomocnych orzeczeń, a w szczególności skargi kasacyjnej.

W państwach stronach Konwencji europejskiej o immunitecie państwa z 1972 r. obowiązują postanowienia tej Konwencji, które dotyczą m.in. zrzeczenia się immunitetu, oraz zasady proceduralne dotyczące postępowania w sprawie z udziałem państwa obcego. W art. 16 Konwencji wprowadzono obowiązek doręczenia pozwanemu państwu obcemu pisma wszczynającego postępowanie. Konwencja ta dopuszcza zrzeczenie się immunitetu wyraźne oraz dorozumiane, nie wprowadzając przy tym wprost żadnych ograniczeń terminowych na skorzystanie przez pozwane państwo obce $z$ tego uprawnienia. W Konwencji tej zrzeczenie się immunitetu państwa może nastąpić zarówno przed wszczęciem postępowania w sprawie, jak i w jego toku. W konsekwencji w państwach stro- 
nach wskazanej Konwencji sąd nie może odrzucić pozwu przed doręczeniem pozwanemu państwu obcemu pisma wszczynającego postępowanie. Sąd powinien najpierw doręczyć to pismo pozwanemu państwu obcemu, poczekać na jego odpowiedź i dopiero stosownie do niej albo odmówić prowadzenia postępowania, albo prowadzić je z udziałem pozwanego państwa obcego.

Kończąc, należy podkreślić, że zrzeczenie się przez państwo obce immunitetu państwa na potrzeby konkretnego postępowania rozpoznawczego nie rozciąga się m.in. na postępowanie egzekucyjne ${ }^{28}$ czy zabezpieczające. Zrzeczenie się immunitetu dotyczy tylko tego postępowania, na potrzeby którego zostało dokonane. Prowadzenie zatem przeciwko państwu obcemu, korzystającemu z immunitetu państwa, innego postępowania cywilnego czy wytoczenie przeciwko niemu powództwa wzajemnego będzie dopuszczalne dopiero po uprzednim zrzeczeniu się przez to państwo immunitetu dotyczącego tego innego postępowania lub sprawy objętej żądaniem z powództwa wzajemnego.

\section{Wnioski}

Za dominujący i jednocześnie zasługujący w pełni na akceptację należy uznać pogląd, według którego państwo obce korzysta w postępowaniu rozpoznawczym w sprawach cywilnych $z$ immunitetu państwa. Jest to tzw. immunitet ograniczony. Co oznacza, że sąd powinien odrzucić pozew wniesiony w sprawie cywilnej przeciwko pozwanemu państwu obcemu, któremu przysługuje w sprawie immunitet państwa. Należy postulować, aby orzeczenie w tym przedmiocie sąd wydawał najwcześniej po doręczeniu pozwanemu państwu obcemu odpisu pozwu i umożliwieniu mu skorzystania z prawa do zrzeczenia się przysługującego immunitetu, czyli innymi słowy umożliwieniu temu państwu zajęcia w tym zakresie stanowiska w sprawie. Z tym jednak zastrzeżeniem, że jak to już wyżej zostało wskazane, sąd powinien odrzucić pozew niezwłocznie po jego wniesieniu, jeżeli stwierdzi wystąpienie innej przeszkody procesowej, której nie można usunąć. Odrzucenie pozwu przed doręczeniem jego odpisu pozwanemu, jeżeli jest oparte na ustawowych podstawach do odrzucenia pozwu, nie stanowi jednak uchybienia procesowego.

Jeżeli pozwane państwo obce, któremu przysługuje w sprawie immunitet państwa, nie zrzeknie się go, czyli nie złoży stosownego oświadczenia lub nie podejmie w sprawie merytorycznej obrony (chodzi tu o obronę, która będzie polegać na podnoszeniu innych zarzutów niż korzystanie z immunitetu państwa), lub przez inne zachowanie nie da powodu do przyjęcia, że w sposób dorozumiany zrzeka się immunitetu, sąd zaś będzie prowadzić przeciwko niemu postępowanie, to będzie ono dotknięte kwalifikowanym uchybieniem procesowym prowa-

${ }_{28}$ Zob. np. A. Jakubowski, Immunitet, op. cit., s. 70 i n. 
dzącym do nieważności postępowania. Oczywiście uchybienie takie będzie można usunąć, wnosząc jeden ze środków zaskarżenia. Niewniesienie zaś tego środka spowoduje, że orzeczenie takie będzie ważne i skuteczne według prawa polskiego. Inną zaś kwestią jest możliwość wykonania orzeczenia wydanego przeciwko państwu obcemu w sprawie, w której państwo to korzysta z immunitetu państwa. Orzeczenie takie będzie bowiem podlegać wykonaniu na terytorium pozwanego państwa obcego i na podstawie przepisów w nim obowiązujących.

Należy podkreślić, że immunitet państwa obcego w postępowaniu rozpoznawczym w sprawach cywilnych i kwestie związane $\mathrm{z}$ jego badaniem nie powinny być uregulowane $\mathrm{w}$ ustawie krajowej, w tym w Kodeksie postępowania cywilnego. Prawo krajowe nie powinno narzucać rozwiązań dotyczących immunitetu państwa. Rozwiązania takie powinny się znaleźć w konwencjach międzynarodowych. Nawet najlepsze przepisy krajowe w praktyce mogą się bowiem okazać niewykonalne. Gdyby przyjąć odmienne zapatrywanie, każde państwo w sposób dla siebie korzystny normowałoby te kwestie, zaś inaczej regulowałoby zagadnienie wykonania orzeczeń zapadłych w takich postępowaniach. Rozwiązania dotyczące dochodzenia roszczeń przed sądami krajowymi od państwa obcego nie mogą się zatem ograniczać jedynie do zagadnienia regulacji immunitetu państwa i możliwości jego zrzeczenia się przez państwo obce, ale także powinny obejmować kwestie związane z późniejszym wykonaniem zapadłego w takim postępowaniu orzeczenia.

\section{Bibliografia}

Ciszewski J., Glosa do postanowienia SN z 11 stycznia 2000 r., sygn. akt I PKN 562/99, OSP 2000, nr 11.

Gruszczyński K., Czy Niemcy mogą być pozywane w Polsce w świetle wyroku Sądu Najwyższego z 2010 r.?, „Studia Prawnicze i Administracyjne” 2012, nr 2(4).

Grzegorczyk P., Immunitet państwa w postępowaniu cywilnym, Warszawa 2010.

Guinchard S. i in., Droit processuel. Droit commun et droit comparé du procès, Paris 2005.

Jakubowski A., Immunitet państwa. Ius cogens a ochrona dziedzictwa kultury - uwagi krytyczne w świetle wyroku MTS z 3.2.2012 r., Niemcy v. Włochy, „Kwartalnik Prawa Publicznego" 2012, t. XII, nr 4.

Jauering O., Zivilprozessrecht, München 2003.

Misiuk-Jodłowska T. (w aktualizacji K. Weitz) [w:] J. Lapierre i in., Postępowanie cywilne, Warszawa 2016.

Olas E., Immunitet jurysdykcyjny państwa $w$ wybranych orzeczeniach sądów krajowych, „Problemy Współczesnego Prawa Międzynarodowego, Europejskiego i Porównawczego" 2017, t. X.

Paulus Ch.G., Zivilprozessrecht. Erkenntnisverfahren, Zwangvollstreckung und Europäisches Zivilprozessrecht, Berlin 2010. 
Rechberger W.H., Simotta D.A., Grundriss des österreichischen Zivilpprozessrechts. Erkenntnisverfahren, Wien 2010.

Siedlecki W., Powództwo obcego państwa i przeciw obcemu państwu przed sądami polskimi, „Palestra” 1936, nr 5.

Sutor J., Immunitet państwa, Warszawa 2011.

Sutor J., Immunitet państwa i immunitet dyplomatyczny a ściganie i karanie zbrodni o charakterze międzynarodowym w świetle statutu rzymskiego, „Przegląd Sądowy” 2017, nr 11/12.

Sutor J., Immunitet dyplomatyczny i immunitet państwa, „Przegląd Sądowy” 2008, nr 4.

Walasik M., Analogia w prawie procesowym cywilnym, Warszawa 2013.

Wasiński M., Immunitet państwa a jurysdykcja terytorialna (na tle orzeczenia SN w sprawie Natoniewski v. RFN), „Państwo i Prawo” 2012, z. 10.

Weitz K., Jurysdykcja krajowa w postepowaniu cywilnym, Warszawa 2005.

Weitz K. [w:] J. Lapierre i in., Postępowanie cywilne, Warszawa 2016.

Wengerek E., Immunitet egzekucyjny państw obcych, „Studia Prawnicze” 1967, nr 17.

Wyrozumska A., Polskie sądy wobec immunitetu państwa obcego, „Państwo i Prawo” 2000, z. 3. 


\section{Obowiązek opieki nad weteranami walk o niepodległość państwa polskiego - analiza konstytucyjnoprawna}

Duty of care for veterans of the struggles for independence of the Polish State - a constitutional analysis: This article concerns a special position of a veteran in the Polish constitutional system. The Constitution states that the Republic of Poland shall take special care of veterans of the struggle for independence, particularly war invalids.. The study describes axiological and historical basis of privileges of veterans. It was also discussed, how this issue was regulated in former constitutions and what assumptions were adopted in the course of preparatory work on the current constitution. A doctrinal understanding of the analyzed institution was described, basing on the literature of the subject. Reflections of the author are also focused on the basic issues related to understanding the duty of care of veterans in its subjective and objective shape.

Keywords: independence, veteran, social service, duty of care

Słowa kluczowe: niepodległość, weteran, świadczenie socjalne, obowiązek opieki

Doktor nauk prawnych, adiunkt w Katedrze Prawa Konstytucyjnego Uniwersytetu Jagiellońskiego; krzys.kozlowski@uj.edu.pl.

\section{Wprowadzenie}

Regulacje konstytucyjne mają różnorodny charakter, a ich istota podyktowana jest koniecznością osiągnięcia zróżnicowanych celów. Większość z nich została uchwalona jako efekt szerszej refleksji o charakterze politycznym, społecznym lub kulturowym. Dotyczy to również czynników natury historycznej, które pozytywnie lub negatywie - determinują doświadczenie funkcjonowania państwa oraz społeczne rozumienie instytucji życia publicznego. W polskiej tradycji ustrojowej elementem tożsamości konstytucyjnej, silnie osadzonej w realiach o charakterze dziejowym, jest zagadnienie pamięci o bohaterach walk o niepodległość, a zatem całej kategorii weteranów, którzy swoimi działaniami przyczynili się do odrodzenia polskiej państwowości, również w tym najbardziej współczesnym jej wymiarze. Nie powinno więc dziwić, że stosowne postanowienia, 
uwzględniające weteranów, zostały zawarte w obowiązującej ustawie zasadniczej. Rzecz w tym przypadku sprowadza się jednak nie tylko do stworzenia aksjologicznych podstaw funkcjonowania państwa, wskazania programu jego działania, ale rzeczywistego, trwałego oraz szczególnego potraktowania (uprzywilejowania) osób, które były zaangażowane w czyn niepodległościowy. Kwestie te są szczególnie trudne do uregulowania, również ze względu na konflikty aksjologiczne wewnątrz danego państwa, ale są także determinowane możliwościami budżetowymi oraz - co nie mniej ważne - stopniem społecznej wrażliwości na potrzebę docenienia służby weteranów.

Niniejsze opracowanie jest jedynie próbą nakreślenia możliwego sposobu rozumienia regulacji dotyczących weteranów oraz ich uprzywilejowania w systemie prawnym. Dodać trzeba, że analiza prowadzona jest przede wszystkim z konstytucyjnoprawnego punktu widzenia, stąd też artykuł w marginalnym zakresie przywołuje ustawowe regulacje dotyczące tego zagadnienia. W pierwszym rzędzie omówiona została aksjologia konstytucyjna obowiązku dbałości o weteranów oraz nakreślono jego szerszy kontekst interpretacyjny. W dalszej części przytoczono regulacje występujące w poprzednich aktach konstytucyjnych oraz propozycje analizowane w toku prac przygotowujących obowiązującą ustawę zasadniczą. Na podstawie literatury przedmiotu wskazano również na doktrynalny sposób rozumienia instytucji oraz zasygnalizowano jej otoczenie ustawowe. Wreszcie rozważania obejmują najbardziej podstawowe kwestie rozumienia - od strony podmiotowej i przedmiotowej - powinności opieki nad weteranami. Całość artykułu wieńczą rekomendacje.

\section{Aksjologia obowiązku oraz kontekst interpretacyjny}

Obowiązująca Konstytucja $\mathrm{RP}^{1}$ szeroko przywołuje różnorodne zasady i wartości, co czyni jej warstwę aksjologiczną istotnie rozbudowaną ${ }^{2}$. Świadectwa takiego stanu rzeczy można poszukiwać zarówno w preambule, jak też w dalszych jej postanowieniach, w szczególności w rozdziale I. Odniesienie się do tych kategorii jest niezbędne, gdyż wyznaczają one perspektywę interpretacji kolejnych postanowień tego aktu i mogą być pomocne w należytej ich konkretyzacji, a potem właściwym zastosowaniu. Dotyczy to również omawianej tematyki badaw$\mathrm{czej}^{3}$. W rozdziale I Konstytucji RP znajduje swoje umiejscowienie art. 19, który

1 Konstytucja Rzeczypospolitej Polskiej z 2 kwietnia 1997 r., Dz.U. nr 78, poz. 483, ze zm.; dalej: Konstytucja RP.

2 Podobnie i z przywołaniem poglądu P. Winczorka o „aksjologicznej wielobarwności” pisze M. Zubik, Podmioty konstytucyjnych wolności, praw i obowiązków, „Przegląd Legislacyjny" 2007, nr 2, s. 26.

3 Orzecznictwo konstytucyjne, dotyczące statusu kombatantów, zazwyczaj szeroko odwołuje się do warstwy aksjologicznej odnośnych aktów prawnych, w tym do wstępów 
stanowi, że: Rzeczpospolita Polska specjalna opiekq otacza weteranów walk o niepodległość, zwłaszcza inwalidów wojennych. Przepis ten nie występuje jednak samodzielnie i ma rozbudowane podstawy odwołujące się do aksjologii konstytucyjnej. Przede wszystkim należy przywołać jego umocowanie w postanowieniach preambuły. Wskazuje ona, że ustawa zasadnicza jest stanowiona w szczególnym momencie historycznym, a więc w czasie, kiedy naród odzyskał w 1989 roku możliwość suwerennego i demokratycznego stanowienia. Towarzysząca temu przemiana nie powstała jednak samoistnie, jest wynikiem zaangażowania polskiego społeczeństwa w ruch „Solidarności”. Upodmiotowienie państwa nastąpiło dzięki działaniu wielu osób oraz instytucji, które były włączone w proces „walki o niepodległość”. Odwoływać się w tej sferze można do różnorodnych form podejmowanych działań, ukierunkowanych lub zgodnych z dążeniem do odzyskania suwerenności, niekoniecznie związanych z bezpośrednią walką zbrojną. Już sam fakt przywołania przez preambułę cezury czasowej 1989 r. jest wystarczająco wymowny i zdaje się nawiązywać do całokształtu wysiłków obywateli pragnących odzyskać „możliwość suwerennego i demokratycznego stanowienia” o przyszłym losie państwa polskiego.

Bezpośrednie odwołanie, niewymagające sięgnięcia po dalszą interpretację, odnaleźć można natomiast w tej części preambuły, w której wyrażona zostaje wdzięczność naszym przodkom za ich prace, za walkę o niepodległość okupiona ogromnymi ofiarami. Postanowienie to wskazuje filary, na których Konstytucja RP jest ustanowiona, a które jednocześnie wyrażają podstawę funkcjonowania współczesnego państwa polskiego i jego tradycji ${ }^{4}$. Język preambuły również i w tym przypadku jest bardzo uroczysty i wyraża wobec weteranów „wdzięczność" za ich działania, a nie jedynie „przywołuje” ich aktywność. Zestawienie tych dwóch pojęć jest bardzo wymowne, pokazuje nie tylko formalny zabieg docenienia działań weteranów, ale również nakazuje podjęcie próby odpłaty na ich rzecz. Może być ona realizowana w różnych sferach. Przede wszystkim mowa tu o publicznym oddawaniu im należytego uszanowania, co może być związane z afirmacją poszczególnych osób lub miejsc, jak również symboli lub wydarzeń o znaczeniu historycznym, a więc dopełnieniu spraw honorowych ${ }^{5}$. Okazja ku temu nadarza się przy okazji świąt państwowych, konkretnych uroczystości, jej wyrazem może być także odpowiednia polityka orderowa głowy państwa (art. 138 Konstytucji RP). Równolegle omawiana „wdzięczność” domaga się podejmowania działań związanych z naprawą krzywd, najczęściej niezawinionych przez polski naród, jakie weterani doznali w związku ze swoją aktywnością. Prze-

i preambuł. Zob. przykładowo: wyrok TK z 15 września 1999 r., sygn. akt K 11/99, OTK 1999, nr 6, poz. 116.

4 L. Garlicki, M. Derlatka, Komentarz do art. 1 [w:] Konstytucja Rzeczypospolitej Polskiej. Komentarz, t. I, red. L. Garlicki, M. Zubik, Warszawa 2016, s. 506.

5 Wyrok TK z 9 marca 2004 r., sygn. akt K 12/02, OTK-A ZU 2004, nr 3, poz. 19. 
de wszystkim będzie to dotyczyło aspektu materialnego, związanego z zapewnieniem dedykowanych świadczeń społecznych lub uprzywilejowanego dostępu do służby zdrowia ${ }^{6}$. Nieco bardziej prospektywna interpretacja preambuły, choć cały czas zakorzeniona w jej języku - zobowiązani, by przekazać przyszłym pokoleniom wszystko, co cenne z ponad tysiącletniego dorobku - domaga się również, aby depozytariuszami pamięci o weteranach oraz wydarzeniach historycznych, w których brali oni udział, były kolejne generacje. Takie jest zresztą zazwyczaj życzenie samych weteranów, którzy chcą być zapamiętywani z perspektywy czynów, których dokonali, oraz wydarzeń, w których brali udział. Roztoczenie „specjalnej opieki” nie ogranicza się bowiem do teraźniejszości, a powinno być wpisane w szerszy wymiar aksjologii konstytucyjnej, związany z zapewnieniem „wdzięczności naszym przodkom”, co może być udziałem współczesnych, a powinno być troską przyszłych pokoleń.

Poza preambułą warto poddać analizie sam art. 19 Konstytucji RP oraz jego dalsze otoczenie normatywne. Został on umiejscowiony w rozdziale I ustawy zasadniczej zatytułowanym „Rzeczpospolita”. Rozdział ten określa podstawowe zasady ustrojowe państwa polskiego, w tym również pryncypia jego funkcjonowania. Nie kwestionując normatywnego charakteru jego postanowień jako części „najwyższego prawa Rzeczypospolitej” (art. 8 ust. 1 Konstytucji RP), warto zwrócić uwagę, że zawiera on regulacje mające charakter również programowy, wyrażające „zasady polityki państwa”. Ukierunkowują one działania organów władzy publicznej na osiągnięcie pożądanych celów, a także wskazują na pewną metodologię funkcjonowania państwa. Artykuł 19 nie jest więc zwykłym przepisem, którego syntaktyczna formuła wyznacza wyłącznie pojedyncze i ściśle określone prawa lub obowiązki, ale „wyraża zasadę ustrojową"”. Jego rozumienie jest zdecydowanie szersze, bo związane z wyznaczeniem programowej i prawnie wiążącej normy funkcjonowania państwa ${ }^{9}$. Organy władzy zobowiązane są zatem do podejmowania działań ukierunkowanych na osiągnięcie zawartego w nim celu, jakim jest otoczenie weteranów odpowiednim („szczególnym”) poziomem opieki. Chodzi tu o pewną optymalizację w sferze działania państwa, wykazywanie należytych dążeń, a nie jedynie poprzestanie na afirmatywnym stwierdzeniu o potrzebie uszanowania osób „walczących o niepodległość". Na taką intencję ustrojodawcy wskazuje zresztą nie tylko umiejscowienie omawianego przepisu w strukturze ustawy zasadniczej, ale również sama warstwa językowa, jak została użyta do jego skonstruowania.

6 K. Ślebzak, Komentarz do art. 19 [w:] Konstytucja RP, t. I, Komentarz. Art. 1-86, red. M. Safjan, L. Bosek, Warszawa 2016, s. 498-499.

7 L. Garlicki, M. Derlatka, Komentarz do art. 19 [w:] Konstytucja Rzeczypospolitej Polskiej. Komentarz, t. I, red. L. Garlicki, M. Zubik, Warszawa 2016, s. 506 i przywołana tam literatura.

$8 \quad$ M. Zubik, Podmioty konstytucyjnych wolności, op. cit., s. 36.

$9 \quad$ L. Garlicki, Polskie prawo konstytucyjne. Zarys wykładu, Warszawa 1999, s. 108 i 117. 
Ogląd prima facie pozwala stwierdzić, że omawiana regulacja ma podniosły charakter. Stanowi się o „weteranach” oraz „walce o niepodległość”, jak również „specjalnej opiece”. Ustrojodawca zdaje się tym samym wyszczególniać potrzebę dbałości o weteranów, zaznaczając ich nadzwyczajną rolę w ukonstytuowaniu się niepodległego państwa polskiego ${ }^{10}$. Nie jest to jednak wyłącznie legislacyjne decorum, a sfera prawnego szczególnego zobowiązania, istniejącego po stronie państwa, które ulega sprecyzowaniu na gruncie ustawowym ${ }^{11}$. Oczywiście od odpowiednich organów, jak również bieżących możliwości budżetowych ${ }^{12}$ zależeć będzie, czy i w jaki sposób zobowiązanie takie będzie mogło być realizowane. Po drugie, przepis dość jednoznacznie precyzuje pewien obowiązek, jakim jest opieka nad weteranami. Zakłada to odpowiedni stopień aktywności po stronie organów władzy publicznej, związanej z realizacją funkcji organizatorskiej, a zatem podejmowania działań, które umożliwiać będą zapewnienie „opieki”, a więc formę protektoratu państwa nad tą szczególną kategorią podopiecznych. Przede wszystkim, choć nie wyłącznie, będzie się to wiązało ze wspomnianym już zapewnieniem świadczeń o charakterze materialnym - zaopatrzeniowym lub medycznym. Po trzecie wreszcie, zobowiązanie organów władzy publicznej do roztoczenia mecenatu nad jego weteranami nie powinno być realizowanie na zasadach ogólnych, a w warunkach „szczególnego” zaangażowania państwa. Chodzi tu o pewien stopień uprzywilejowania weteranów, w tym inwalidów wojennych, w systemie prawnym ${ }^{13}$. Dotyczy to zwłaszcza sfery przyznawanych im świadczeń lub zwalniania z obowiązków, co powoduje konieczność prawnego ich wyróżnienia na tle innych uczestników obrotu prawnego.

\section{Regulacje historyczne, rozumienie przepisu i współczesne otoczenie regulacyjne}

Szczególna pozycja prawna weteranów walk o niepodległość, jakkolwiek raczej powszechnie akceptowana w wymiarze publicznym, nie ma długiej tradycji regulacyjnej na poziomie konstytucyjnym. Dość tylko wspomnieć, że Konstytucja marcowa $^{14}$ nie zawierała w tej mierze żadnych wiążących postanowień, a jedynie w preambule odwoływała się do wdzięczności za: męstwo i wytrwałość ofiarnej walki pokoleń, które najlepsze wysitki swoje sprawie niepodległości bez przerwy

10 Podobnie wyrok TK z 15 września 1999 r., sygn. akt K 11/99.

11 J. Boć, Komentarz do art. 19 [w:] Konstytucje Rzeczypospolitej oraz komentarz do Konstytucji RP z 1997 roku, red. J. Boć, Wrocław 1998, s. 19.

12 Wyrok TK z 9 marca 2004 r., sygn. akt K 12/02.

13 Podobnie wyrok TK z 15 kwietnia 2003 r., sygn. akt SK 4/02, OTK-A ZU 2003, nr 4, poz. 31.

14 Ustawa z 17 marca 1921 r. - Konstytucja Rzeczypospolitej Polskiej, Dz.U. nr 44, poz. 267. 
poświęcały. Również Konstytucja kwietniowa ${ }^{15}$ nie regulowała tego zagadnienia i ograniczała się jedynie do podkreślenia, że państwo polskie: wskrzeszone walka i ofiara najlepszych swoich synów ma być przekazywane w spadku dziejowym (...). Pierwsza kompleksowa regulacja zagadnienia pojawiła się w Konstytucji lipcowej, a konkretnie na mocy ustawy ją nowelizującej z $1976 \mathrm{r}^{16}{ }^{16}$, kiedy to dodano art. 64a (art. 76 tekstu jednolitego ${ }^{17}$ ) o treści: Polska Rzeczpospolita Ludowa zapewnia wszechstronna opieke weteranom walk o wyzwolenie narodowe $i$ społeczne. Omawiana materia nie była też przedmiotem szczególnego zainteresowania $\mathrm{w}$ toku prac nad obowiązującą Konstytucją RP, a obecne brzmienie art. 19 pojawiło się dopiero w ciągu dalszych prac prawodawczych, prowadzonych w marcu $1997 \mathrm{r}$. Ostateczna redakcja omawianego przepisu ma swoje źródło w trzech poprawkach zgłoszonych podczas dyskusji w Komisji Konstytucyjnej Zgromadzenia Narodowego. Każda z nich nieco inaczej akcentowała materię regulacyjną. Pierwsza propozycja została złożona przez posła A. Dobrońskiego, który przywołał stwierdzenie, że: Rzeczpospolita Polska szczególna opieka otacza obrońców Ojczyzny $i$ osoby poddane represjom za walkę o Jej niepodległośćc ${ }^{18}$. Drugi wniosek, przedłożony przez senatora R. Jarzembowskiego, przewidywał, że Polska: otacza głębokim szacunkiem i zapewnia socjalna opiekę kombatantom walk o niepodległość $i$ integralność terytorialna $(. . .)^{19}$. Oba założenia przyporządkowują uprawnienia weteranów przede wszystkim do sfery świadczeń socjalnych, choć druga z nich akcentuje również kwestie publicznego ich uszanowania. Wreszcie trzecia propozycja, złożona przez poseł M. Dmochowską, jest tożsama z obowiązującą redakcją art. 19 Konstytucji $\mathrm{RP}^{20}$. W toku dalszych prac niestety nie przeprowadzono szczerszej dyskusji nad problematyką uprzywilejowania weteranów. Jedynym zagadnieniem, jakie marginalnie poruszono, była sfera umiejscowienia regulacji w systematyce konstytucyjnej. Spierano się o to, czy ma być to część uwarunkowań ogólnych, czy też jest to kwestia uprawnień socjalnych, a zatem podlega ulokowaniu w poświęconej temu zagadnieniu części ustawy zasadniczej ${ }^{21}$.

Kwestia dbałości o kondycję weteranów jest również dostrzegana w literaturze przedmiotu. Analizę konstytucyjną przeprowadza m.in. W. Skrzydło, który podkreśla zwyczajowe umocowanie omawianej instytucji. Podnosi w szczególności, że jest: polską tradycją, że państwo i społeczeństwo w dowód uznania dla

15 Ustawa Konstytucyjna z 23 kwietnia 1935 r., Dz.U. nr 30, poz. 227.

16 Ustawa z 10 lutego 1976 r. o zmianie Konstytucji Polskiej Rzeczypospolitej Ludowej, Dz.U. nr 5, poz. 29.

17 Obwieszczenie Przewodniczącego Rady Państwa z 16 lutego 1976 r. w sprawie ogłoszenia jednolitego tekstu Konstytucji Polskiej Rzeczypospolitej Ludowej uchwalonej przez Sejm Ustawodawczy 22 lipca 1952 r., Dz.U. nr 7, poz. 36.

18 Biuletyn Komisji Konstytucyjnej Zgromadzenia Narodowego, 1997, nr 44, s. 5.

19 Ibidem, s. 6.

20 Ibidem.

${ }^{21}$ Ibidem, s. 5-7. 
weteranów walk o niepodległość, zwłaszcza tych, którzy na polach walki ponieśli ofiary, (...) przyznaje im specjalna opiekę państwa. Jednocześnie Autor ten wskazuje, że przepis Konstytucji RP jest generalny i ustanowiony: bez precyzowania zakresu ani te $\dot{z}$ form tej opieki i pomocy, bowiem te kwestie rozstrzyga parlament $w$ drodze ustaw ${ }^{22}$. Z kolei K. Ślebzak akcentuje socjalny wymiar praw weteranów i zdaje się kwestionować umieszczenie tej regulacji w pierwszym rozdziale Konstytucji RP. Argumentuje, że przepis: dotyczy powinności otoczenia szczególna opieką określonej kategorii osób. (...) nie ma wątpliwości, że chodzi o formę pomocy skierowanej również do osób niezdolnych, choćby częściowo, do wykonywania pracy $(\ldots)^{23}$. Ciekawy pogląd prezentuje K. Complak, który postuluje zniesienie analizowanego przepisu z powołaniem na argument, że: zakłada on, ni mniej ni więcej - jak przystało na dokument pomyślany na dłuższy czas obowiązywania stałe (częste) prowadzenie walk o niepodległość oraz - co jest jeszcze ciekawsze uciekanie się do wojny zakazanej przez prawo międzynarodowe ${ }^{24}$. L. Garlicki oraz M. Derlatka podkreślają systemowy walor art. 19 Konstytucji RP i w tym zakresie zwracają uwagę na jego dychotomiczny charakter. W tym względzie podnoszą, że: określono w nim przede wszystkim zasade polityki państwa (...), jego umiejscowienie w systematyce konstytucyjnej [wskazuje - przyp. K.K.], że zasada ta jest na tyle istotna, iż należało ja pomieścić wśród podstawowych zasad wyznaczajacych porządek społeczny, [a zarazem ten obowiązek - przyp. K.K.] jest ujęty w sposób bardziej kategoryczny, niż „typowe” przepisy o zasadach polityki państwa ${ }^{25}$. Na zakończenie warto przytoczyć chyba najbardziej trafną wypowiedź - M. Jabłoński sygnalizuje, że: nie było błędem traktowanie art. 19 Konstytucji RP jako szczególnego rodzaju konstrukcji prawnej odnoszącej się do państwa polskiego i odpowiednich władz (przede wszystkim władzy ustawodawczej i wykonawczej), i definiujace ich obowiązki $w$ zakresie stworzenia elementów systemu pomocy (opieki) socjalnej, którego adresatem miała być określona grupa społeczna, w tym przypadku weterani walk o niepodległość ( $w$ tym inwalidzi wojenni) ${ }^{26}$. W świetle przywołanych ustaleń doktrynalnych art. 19 Konstytucji RP jawi się przede wszystkim jako podstawowa zasada ustrojowa, mająca swoje umocowanie w silnej tradycji. Co więcej, przepis ten definiuje określone zobowiązanie po stronie władz publicznych, pozostawiając jednak ustawodawcy zwykłemu określenie katalogu i przesłanek nabycia takich przywilejów ${ }^{27}$.

22 W. Skrzydło, Konstytucja Rzeczypospolitej Polskiej. Komentarz, Warszawa 2013.

23 K. Ślebzak, Komentarz do art. 19, op. cit., s. 496.

24 K. Complak, Komentarz do art. 19 [w:] Konstytucja Rzeczypospolitej Polskiej. Komentarz, red. M. Haczkowska, Warszawa 2014.

25 L. Garlicki, M. Derlatka, Komentarz do art. 19, op. cit., s. 506-507.

26 M. Jabłoński, Prawo weteranów do specjalnej opieki ze strony państwa [w:] Realizacja i ochrona konstytucyjnych wolności i praw jednostki w polskim porzadku prawnym, red. M. Jabłoński, Wrocław 2014, s. 607.

27 Zob. postanowienie SN z 20 sierpnia 2014 r., sygn. akt II KK 221/14, LEX nr 1504561. 
Pierwsze zetknięcie się z przepisem art. 19 Konstytucji RP zwraca uwagę na jego afirmatywny charakter. Podkreślono w nim rolę weteranów walk o niepodległość w systemie ustrojowym państwa polskiego. Wskazuje to na wolę prawodawcy szczególnego wyróżnienia weteranów, a zarazem rodzi konieczność adekwatnego ich potraktowania na gruncie systemu prawnego. Treść przepisu przekonuje, że nie tylko dla zadośćuczynienia w sferze etycznej i społecznej został on ustanowiony, ale również podyktowany jest wymogiem takiego ukształtowania reguł systemowych, aby ta szczególna grupa osób doznawała nadzwyczajnego i trwałego uprzywilejowania, była adresatem takich uprawnień, które dla innych podmiotów nie będą już szerzej dostępne ${ }^{28}$. Trzeba również zwrócić uwagę na programowy aspekt analizowanego przepisu. Fakt umieszczenia go w rozdziale I ustawy zasadniczej, wśród innych podstawowych zasad ustrojowych ${ }^{29}$, przesądza o publicznej doniosłości działań niepodległościowych. Źródeł obowiązku uszanowania i docenienia weteranów należy poszukiwać w utrwalonej tradycji społecznej, jak również - będącej jej pochodną - aksjologii wysłowionej w konstytucyjnej preambule. Tam też zdaje się być ulokowane podstawowe źródło, baza wartości i zasad, na których analizowany przepis został ufundowany. Jest chyba sprawą niezaprzeczalną, że narodowa percepcja państwa, historyczna narracja jego funkcjonowania, oparta jest na etosie bohaterów walk o niepodległość oraz wydarzeń, w które osoby te były zaangażowane. Ze sferą tą zdaje się współgrać inny jeszcze sposób rozumienia komentowanej regulacji. Można bowiem przyjąć, że równolegle stanowi ona dyrektywę interpretacyjną, nadającą kierunek rozumienia przepisów ustaw zwykłych oraz aktów stosowania prawa, a potem jeszcze praktycznego aspektu ich wykonywania ${ }^{30}$. Rzecz sprowadza się do przyjęcia, że art. 19 Konstytucji RP posługuje się pojęciami o charakterze aksjomatycznym, a ich adresatem jest przede wszystkim ustawodawca zwykły. Spoczywa na nim zasadniczy ciężar wykonania założeń konstytucyjnych, a zatem powinien otoczyć weteranów maksymalnie uprzywilejowaną i „szczególną opieką", przy jednoczesnym racjonalnym odwołaniu się do bieżących możliwości budżetowych. Dyrektywalne ujęcie przepisu nakazuje także, aby wszystkie inne podmioty stosujące prawo, $w$ tym organy administracyjne oraz sądy, czyniły to zgodnie z zasadą operacjonalizacji normy konstytucyjnej, a więc - w ślad za ustawodawcą zwykłym - dążyły to należytego i możliwie efektywnego uprzywilejowania weteranów ${ }^{31}$. Z tą ostatnią kwestią związany jest ostatni wymiar rozumie-

$28 \quad$ K. Ślebzak, Komentarz do art. 19, op. cit., s. 499.

29 M. Zubik, Podmioty konstytucyjnych wolności, op. cit., s. 36.

30 Na problemy z tym związane wskazuje M. Schwarzgruber, Weteran czy kombatant, „Polska Zbrojna” 2013, nr 10, s. 53.

31 O intensywności działań w tym wymiarze zob. L. Garlicki, Komentarz do rozdziału II Wolności, prawa i obowiązki człowieka i obywatela [w:] Konstytucja Rzeczpospolitej Polskiej. Komentarz, t. III, red. L. Garlicki, Warszawa 2007, s. 4. 
nia art. 19 Konstytucji RP - choć nie jest to pogląd jednolicie podzielany ${ }^{32}$ - jako ustanawiającego prawo podmiotowe ${ }^{33}$. Bez wątpienia nie jest to bowiem przepis, który wyłącznie przywołuje regułę ustrojową lub ma charakter programowy, ale również statuuje określone prawo dla weteranów walk o niepodległość. Mogą oni jednak to prawo wykonywać na zasadach określonych w ustawie, przy jednoczesnym ponownym podkreśleniu zobligowania prawodawcy do zaangażowania w stałą i proporcjonalną realizację uzasadnionych potrzeb tej grupy osób ${ }^{34}$.

Analiza ustaw wykonujących art. 19 Konstytucji RP, jakkolwiek bardzo pożyteczna, wykraczałaby poza ramy niniejszego opracowania. Warto tu jednak wskazać, że cieszy się on znacznym otoczeniem regulacyjnym. Najszersze unormowania w tej dziedzinie przewiduje ustawa z 24 stycznia 1991 r. o kombatantach oraz niektórych osobach będących ofiarami represji wojennych i okresu powojennego (t.j. Dz.U. 2018, poz. 276, ze zm.). Wymienia ona poszczególne kategorie wydarzeń historycznych, które związane są z możliwością nabycia statusu kombatanta, oraz zawiera definicję takiej osoby, która istotnie nawiązuje do art. 19 Konstytucji RP. Jej uzupełnieniem jest ustawa z 24 lipca 1999 r. o szczególnych zasadach, warunkach i trybie mianowania na wyższe stopnie wojskowe żołnierzy uczestniczących w walkach o wolność i niepodległość Polski podczas II wojny światowej i w okresie powojennym (Dz.U. nr 72, poz. 804, ze zm.). Pozwala ona na awansowanie, również pośmiertne, osób służących na frontach II wojny światowej oraz okresie powojennym, które nie dostąpiły takiej możliwości ze względu na represyjny charakter działalności władz po 1945 r. Wreszcie, w odniesieniu do statusu weteranów bliższego nam dziejowo okresu, ustawodawca przyjął ustawę z 20 marca 2015 r. o działaczach opozycji antykomunistycznej oraz osobach represjonowanych z powodów politycznych (t.j. Dz.U. 2018, poz. 690, ze zm.) oraz jej - nastawione na aspekt jurydyczny - dopełnienie uregulowane w ustawie z 23 lutego 1991 r. o uznaniu za nieważne orzeczeń wydanych wobec osób represjonowanych za działalność na rzecz niepodległego bytu Państwa Polskiego (t.j. Dz.U. 2017, poz. 1987, ze zm.). Prawodawca dostrzegł również wysiłek weteranów, którzy podejmowali służbę w misjach poza granicami kraju, i przyjął ustawę dedykowaną także tym działaniom ${ }^{35}$. Docenił tym samym współczesne wyzwania związane z zapewnieniem państwu polskiemu niepodległości w wymiarze uniwersalnym i w odpowiedzi na zagrożenia o takim charakterze. Z tego prostego zestawienia regulacji wynika, że współcześnie $\mathrm{w}$ polskim systemie prawnym mamy do czynienia $\mathrm{z}$ powstaniem wyodrębnionej

32 Tak z powołaniem na umiejscowienie przepisu w rozdziale I Konstytucji RP pisze M. Zubik, Podmioty konstytucyjnych wolności, op. cit., s. 36.

33 Wyrok TK z 15 kwietnia 2003 r., sygn. akt SK 4/02.

34 Częściowo odmiennie L. Garlicki, Komentarz do rozdziału II, op. cit., s. 5.

35 Ustawa z 19 sierpnia 2011 r. o weteranach działań poza granicami państwa, t.j. Dz.U. 2018, poz. 937, ze zm. 
gałęzi regulacyjnej „prawa weteranów”. Z drugiej jednak strony obfitość regulacji oraz wątpliwości związane $\mathrm{z}$ ich wzajemnym przenikaniem się uprawniają do zaprezentowania postulatu de lege ferenda o potrzebie przyjęcia wyczerpującej kodyfikacji w tej dziedzinie.

\section{„Weterani walk o niepodległość" - zakres podmiotowy przepisu}

Podanie chociażby przybliżonej definicji zakresu podmiotowego art. 19 Konstytucji RP jest zadaniem niełatwym. Przede wszystkim dlatego, że ustawa zasadnicza posługuje się zwrotami natury ogólnej, mającymi niedookreślony charakter ${ }^{36}$. Zadaniem ustawodawcy zwykłego będzie zatem odpowiednie ich doprecyzowanie oraz wskazanie, jakie kategorie podmiotów będą adresatami „szczególnej opieki" świadczonej ze strony organów władzy publicznej, a jakie grupy osób - ze względu na negatywnie kwalifikowane uwarunkowania natury historycznej lub osobniczej $^{37}$ - będą jej pozbawione ${ }^{38}$. Niemniej już na gruncie pobieżnej lektury tego przepisu możliwe jest wskazanie pewnego kontekstu interpretacyjnego, co jednak nie wyklucza daleko posuniętej swobody ustawodawcy w tym zakresie. Obowiązująca Konstytucja RP posługuje się pojęciem „weterana”, jednak go nie definiuje, zastrzegając jedynie, że cechę taką odnosi do osoby „walczącej o niepodległość. Przyjąć trzeba, że dotyczy to działań podejmowanych na rzecz Rzeczypospolitej ${ }^{39}$. Istotne jest również to, że - przy zróżnicowaniu dyskursu historycznego w Polsce ${ }^{40}$ - obie kategorie nie mają charakteru obiektywnego, co pogłębia trudność w odczytaniu ustawy zasadniczej. To bowiem, co w subiektywnym oglądzie będzie działaniem na rzecz niepodległości, może być z innego punktu widzenia krytykowane jako działanie uniemożliwiające nadanie statusu weterana ${ }^{41}$. Cechę „weterana”, jak się wydaje, można zaś przypisać osobie, która

36 Podobnie M. Jabłoński, Prawo weteranów, op. cit., s. 609.

37 Wyrok TK z 15 września 1999 r., sygn. akt K 11/99.

38 Zob. analizę orzecznictwa dotyczącego utraty statusu kombatanta przez osoby służące w aparacie bezpieczeństwa NKWD lub PRL: S. Szymańska, Realizacja ustawy o kombatantach $w$ świetle orzecznictwa SN, „Przegląd Sądowy” 1998, nr 2, s. 15-33.

39 Wyrok TK z 19 grudnia 2012 r., sygn. akt K 9/12, OTK-A ZU 2012, nr 11, poz. 136.

40 Z przywołaniem "różnych ocen co do niepodległości Państwa Polskiego w latach 1945-1989": K. Ślebzak, Komentarz do art. 19, op. cit., s. 497.

${ }_{41}$ Trafnie jest ten problem diagnozowany w literaturze przedmiotu. Przykładowo, w odniesieniu do ustawy gwarantującej kombatantom różne formy opieki, stwierdzano, że: z jednej strony przyznała [ustawa - przyp. K.K.] uprawnienia w niej przewidziane osobom, które nie byly uznawane za kombatantów w poprzednim stanie prawnym, $z$ drugiej zaś - nie objęła pojęciem kombatanta niektórych grup osób uznawanych dotychczas za kombatantów, S. Szymańska, Realizacja ustawy, op. cit., s. 15. 
wzięła udział w działaniach, które przyczyniły się do osiągnięcia celu o charakterze publicznym, dotyczącego realizacji zamierzenia społeczno-politycznego, związanego z utworzeniem lub odnowieniem danej struktury państwowej, jak również zapewnieniem bezpieczeństwa państwowego, przede wszystkim w wymiarze zewnętrznym. Najczęściej będzie to dotyczyło zaangażowania w walkę narodowowyzwoleńczą lub też działanie ukierunkowane na uzyskanie lub odzyskanie niepodległości, względnie wzięcie udziału w przełomie politycznym, którego skutkiem jest utworzenie lub odnowienie danej państwowości, jak również obrona granic państwa przed działaniami agresora. Warunkiem nabycia statusu weterana będzie zatem jakaś forma osobistej aktywności w którejś ze wskazanych dziedzin ${ }^{42}$.

Na gruncie art. 19 Konstytucji RP nie każdy jednak „weteran” będzie upoważniony do korzystania z przywilejów zastrzeżonych w tym przepisie. Czysto formalne (słownikowe) znaczenie pojęcia „weterana” ma zarówno pozytywny, jak również może mieć negatywny wydźwięk. Z tego też względu ustawa zasadnicza odwołuje się do kategorii weterana „walki o niepodległość”, a więc osoby, która podjęła określoną aktywność w sposób oraz z motywów zasługujących na szczególną aprobatę. Afirmatywna wymowa przepisu zdaje się tu być oczywista i zastrzegać szczególny status jedynie dla osób, które w wymiarze historycznym przyczyniły się do odzyskania przez państwo polskie niepodległości. Kategoria działań związanych z „walką o niepodległość” nie wyczerpuje się jednak wyłącznie w sferze walki zbrojnej, choć głównie taki charakter będzie pewnie przybierać ${ }^{43}$. Zakres tego pojęcia może być bowiem odnoszony zarówno do osób, które wzięły udział w czynnej walce z bronią w ręku, stanowiły wojskowe siły pomocnicze lub zapasowe (sfera paramilitarna), ale również wspomagały tego typu działania, m.in. pełniąc funkcje (kontr)wywiadowcze, a w innych jeszcze przypadkach brały udział w strajkach lub były odpowiedzialne za utrzymanie odpowiedniego poziomu społecznego morale lub też prowadzenie polityki informacyjnej. Dlatego wydaje się, że przyjęta forma (sposób) walki nie jest tu okolicznością przesądzającą, a: szczególne zasługi tych wszystkich obywateli polskich, którzy walczyli o suwerenność i niepodległość Rzeczypospolitej Polskiej w sposób jawny (na polach walki zbrojnej lub w formacjach wojskowych), bądź też w sposób niejawny ( $w$ podziemnych organizacjach niepodległościowych lub $w$ działalności cywilnej) narażając się na represje. Nie czyni w tym względzie żadnej różnicy pomiędzy walka zbrojna $w$ formacjach wojskowych, a walka polegajaca na działalności konspiracyjnej w organizacjach niepodległościowych, o ile działalność taka wiązała się z narażeniem na represje ${ }^{44}$. Należy przy tym zauważyć, że Konstytucja

42 Zob. szerokie ujęcie „walki o niepodległość” w: B. Banaszak, Konstytucja Rzeczypospolitej Polskiej. Komentarz, Warszawa 2009, s. 122.

43 Zob. L. Garlicki, Komentarz do rozdziału II, op. cit., s. 5.

44 Tak również: wyrok TK z 15 września 1999 r., sygn. akt K 11/99. 
RP posługuje się szerszym pojęciem „walki o niepodległość”, a nie węższym znaczeniowo zwrotem „walki zbrojnej o niepodległość” ${ }^{45}$. Węzłowa, i wystarczająca zarazem, jest zatem sama aktywność jednostki, połączona z przeświadczeniem o służebnym charakterze podejmowanych działań, jak również ich rezultat wpisujący się w realizację idei niepodległościowej. W konsekwencji dopuszczalne formy działań służących: „walce o niepodległość" moga być określane relatywnie szeroko, a ich ostateczne unormowanie pozostaje $w$ gestii ustawodawcy zwyktego. Cieszy się on w tym przypadku daleko posunięta swoboda regulacyjna, przede wszystkim ze względu na aksjologię preambuty, przez co nie musi w tych przypadkach „zachowywać neutralnego stanowiska wobec przeszłości” ${ }^{\text {" }}$.

Sugestywna jest okoliczność, że ustrojodawca posłużył się jedynie kategorią „walki o niepodległość”, odstępując jednak od precyzyjnego wskazania, w jakim okresie dany „weteran” miał podejmować swoje działania. $Z$ uwagi na zasadę nieprzerwanej podmiotowości państwa polskiego ${ }^{47}$ nie powinno budzić wątpliwości, że przepis wyznacza jedynie ogólną cezurę czasową i odnosi ją do działań, które obecnie mają wymiar historyczny, bez względu już jednak na odległość czasową od momentu ustanowienia Konstytucji RP lub też chwili jej stosowania. Państwo polskie pozostaje dłużnikiem osób, które podjęły działania związane z odzyskaniem - jak chce tego preambuła - „możliwości suwerennego i demokratycznego stanowienia", a więc umożliwiły odtworzenie oraz obronę polskiej podmiotowości państwowej ${ }^{48}$. Skoro określone osoby ówcześnie działały na rzecz Rzeczypospolitej, toteż zdają się być one naturalnym adresatem uprzywilejowania wynikającego z art. 19 Konstytucji RP. Państwo polskie ma wobec nich szczególne moralne i historyczne zobowiązanie do sprawiedliwej odpłaty, wynagradzającej poniesiony trud oraz wszelkie szkody związane z aktywnością na rzecz odzyskania niepodległości ${ }^{49}$. Z tej perspektywy nie budzi wątpliwości działalność osób, która została podjęta w dzisiaj już historycznym wymiarze, a więc przykładowo w trakcie międzywojnia lub II wojny światowej oraz w okresie po niej następującym, w tym również w czasie tzw. karnawału Solidarności ${ }^{50}$. Nie można jednak zapominać, że szczególne wyzwania związane z zapewnieniem bezpieczeństwa, ich wieloaspektowość oraz najczęściej uniwersalny charakter, powodują, że sfera

45 Odmiennie i z powołaniem na aspekt „użycia siły (...) niosącej realne ryzyko utraty życia bądź zdrowia”: L. Garlicki, M. Derlatka, Komentarz do art. 19, op. cit., s. 509.

46 W. Brzozowski, Bezstronność światopoglądowa władz publicznych w Konstytucji RP, Warszawa 2011, rozdz. 7: Stosowalność wymogu neutralności do różnych dziedzin życia zbiorowego.

47 M. Błachucki, Ciagłość i tożsamość prawna państwa polskiego, „Przegląd Prawniczy Uniwersytetu Warszawskiego" 2004, nr 1, s. 10-14.

48 Zob. B. Banaszak, Konstytucja, op. cit., s. 122 i 124.

49 Na restytucyjny charakter świadczeń kombatanckich wskazuje orzecznictwo sądowe, zob. S. Szymańska, Realizacja ustawy, op. cit., s. 32.

50 Podobnie M. Jabłoński, Prawo weteranów, op. cit., s. 609, 611, 514. 
„Walki o niepodległość”, jak również starań o utrzymanie tego przymiotu, jest realizowana za pomocą działań podejmowanych współcześnie, przykładowo w toku pokojowych lub militarnych misji zagranicznych ${ }^{51}$. Nie bez znaczenia jest w tej sferze fakt, że art. 89 ust. 1 Konstytucji RP przewiduje możliwość związania się przez państwo polskie umową międzynarodową, która dotyczy „pokoju, sojuszy, układów politycznych i wojskowych”. Już tylko w wymiarze prawnym oznacza to możliwość przeniesienia odpowiedzialności za sferę bezpieczeństwa własnego państwa na poziom dalece bardziej uniwersalny niż tylko związany z udziałem w historycznie odległych konfliktach zbrojnych. Poświęcenie ze strony współczesnych weteranów, ich poczucie misji oraz służebnej roli wobec państwa polskiego, ukierunkowanej na zapewnienie krajowi bezpieczeństwa jako niezbędnego elementu niepodległości, nie pozwala na dokonywanie w tej sferze jakichkolwiek rozróżnień, co prowadziłoby tylko do nieuprawnionej dyskryminacji (art. 19 w związku z art. 32 Konstytucji RP) ${ }^{52}$. Przepis ustawy zasadniczej nie wprowadza tu żadnej cezury czasowej, a zatem - lege non distinguente - taka ingerencja ze strony ustawodawcy zwykłego nie byłaby uprawniona, co jednak nie oznacza możliwości dywersyfikacji lub różnorodnego uprzywilejowania, jakie oferowane może być poszczególnym grupom weteranów.

Status weterana uprzywilejowanego został zastrzeżony wyłącznie dla osoby, która „walczyła o niepodległość”. Na tym tle może powstać pytanie o to, czy zakres normowania art. 19 Konstytucji RP obejmuje wyłącznie obywateli polskich, czy też osoby, które takim przymiotem się nie legitymują. Ustawa zasadnicza w tej sferze milczy. Wydaje się jednak, że z uprawnień zastrzeżonych dla weteranów mogą korzystać przede wszystkim obywatele polscy. Z mocy art. 85 ust. 1 Konstytucji RP to właśnie na obywatelach polskich spoczywa „obowiązek obrony Ojczyzny”. Nie budzi więc wątpliwości, że obywatele realizując taką powinność, mogą stać się jednocześnie podmiotami wyznaczonymi na mocy art. 19 Konstytucji RP. Nie jest przy tym niczym niewłaściwym, że dane państwo w pierwszej kolejności zaspokaja potrzeby osób związanych z nim węzłem obywatelstwa, jako bezpośrednio zainteresowanych obroną swojego kraju, jak również najczęściej $\mathrm{w}$ ten proces włączonych. Istotna jest w takich przypadkach kwestia budżetowa. Prawne uprzywilejowanie określonych grup społecznych, w tym również weteranów, niesie określone skutki finansowe, stąd też powinny być one przede wszystkim adresowane do osób ściśle związanych z danym krajem, czego funkcją jest instytucja obywatelstwa. Nie oznacza to jednak, że zakres podmiotowy art. 19 Konstytucji RP wyklucza możliwość nadawania szczególnych uprawnień osobom, które nie mają tego statusu ${ }^{53}$. Przemawiają za tym przede wszystkim wzglę-

\footnotetext{
51 Odmiennie co do weteranów współczesnych działań poza granicami państwa K. Ślebzak, Komentarz do art. 19, op. cit., s. 497-498.

52 Wyrok TK z 23 września 1997 r., sygn. akt K 25/96, OTK 1997, nr 3-4, poz. 36.

53 Podobnie M. Jabłoński, Prawo weteranów, op. cit., s. 609.
} 
dy natury funkcjonalnej. Zdarza się bowiem, że niektóre osoby, które walczyły o niepodległość Rzeczypospolitej, ze względu na różnorodne uwarunkowania, częstokroć będące poza zakresem ich woli, utraciły polskie obywatelstwo ${ }^{54}$. Nie zerwały jednak swoich związków z ojczyzną ani też nie utraciły polskiej tożsamości. Odpowiadają tym samym konstytucyjnej kategorii „rodaków rozsianych po świecie” (preambuła) oraz „Polaków zamieszkałych za granicą” (art. 6 ust. 1 Konstytucji RP). Tym samym możliwość przydania im szczególnych uprawnień nadal pozostawałaby w zakresie regulacji konstytucyjnej, a brak formalnej więzi obywatelskiej jest $\mathrm{w}$ tych przypadkach kompensowany nie tylko samym pochodzeniem tych osób, ale też ulega istotnemu wzmocnieniu przez wymowny fakt walki o niepodległość państwa polskiego. Takie czyny są przecież najgłębszym świadectwem „bezinteresownego działania”, dbałości o Rzeczpospolitą, rozumianą jako dobro wspólne, co wpisuje takie osoby w paradygmat wynikający z art. 1 Konstytucji $\mathrm{RP}^{55}$. Równocześnie nie ma konstytucyjnych przeszkód, aby status oparty na art. 19 Konstytucji RP został nadany osobom niemającym, formalnego lub wynikającego z pochodzenia, związku z Polską. Przepis jest w tej sferze kategoryczny i nakazuje objąć troską wszystkich „weteranów walk o niepodległość”. Wyraża on powinność natury etycznej, wynikającą z wdzięczności wobec osób, które przyczyniły się do odzyskania lub utrzymania podmiotowości państwowej. Jeżeli zatem dana osoba w tym celu podejmowała swoje działania, to bez względu na ewentualny stopień lub charakter jej związania z państwem polskim, teraźniejszym lub obecnym, powinna zyskać status weterana i jest adresatem uprzywilejowania przewidzianego w art. 19 Konstytucji $\mathrm{RP}^{56}$.

\section{Opieka nad weteranami - adresat obowiązku i jego zakres}

Próba odpowiedzi na pytanie o zakres uprzywilejowania weteranów, wynikający $\mathrm{z}$ art. 19 Konstytucji RP, powinna być poprzedzona wskazaniem adresata obowiązku płynącego $\mathrm{z}$ tego przepisu. Jest to o tyle utrudnione, że prawodawca nie wskazuje de nomine właściwego podmiotu. Znamienne jest również to, że nie posługuje się pojęciem „władz publicznych”, a jedynie poprzestaje na przywołaniu „Rzeczypospolitej Polskiej”, która ów obowiązek ma wypełnićs7. Z tej perspektywy nie powinno chyba jednak budzić wątpliwości, że obowiązek otoczenia „specjalną opieką weteranów” spoczywa przede wszystkim na organach władzy

54 G. Kulka, Nadawanie, pozbawianie i przywracanie obywatelstwa polskiego $w$ czasie II wojny światowej, „Czasopismo Prawno-Historyczne” 2011, nr 1, s. 147-167.

55 M. Piechowiak, Dobro wspólne jako fundament polskiego porządku konstytucyjnego, Warszawa 2012, s. 433-434.

56 Odmiennie L. Garlicki, Komentarz do rozdziału II, op. cit., s. 5.

57 L. Garlicki, M. Derlatka, Komentarz do art. 19, op. cit., s. 510. 
państwowej, w tym organach prawodawczych i wykonawczych ${ }^{58}$. Te ostatnie są bowiem odpowiedzialne za prowadzenie wszystkich spraw państwa. Na organach państwowych spoczywa również „stanie na straży suwerenności i bezpieczeństwa państwa oraz nienaruszalności i niepodzielności jego terytorium" (art. 126 ust. 2 Konstytucji RP), jak również „prowadzenie polityki wewnętrznej i zagranicznej Rzeczypospolitej (...)” (art. 146 ust. 1 Konstytucji RP), w szczególności w zakresie zapewnienia „bezpieczeństwa wewnętrznego państwa oraz porządku publicznego" i „bezpieczeństwa zewnętrznego państwa” (art. 146 ust. 4 pkt 7 i 8 Konstytucji RP). Należyte zagwarantowanie wypełniania tych funkcji jest zaś nieodzowne dla utrzymania wielowymiarowej sfery bezpieczeństwa państwa, jako niezbędnego komponentu jego niepodległości, o którą - zgodnie z art. 19 Konstytucji RP - upominać się miały osoby uprawnione. Istnieje więc bezpośrednia funkcjonalna oraz prakseologiczna zależność pomiędzy jurysdykcją organów władzy państwowej a sferą działania - i tym samym podstawą uprzywilejowania - weteranów walk o niepodległość.

Równolegle powstaje pytanie, czy przedmiotowe zobowiązania spoczywają również na jednostkach samorządu terytorialnego. Zgodnie z art. 163 Konstytucji RP wykonuje on zadania, które na mocy odrębnych przepisów, nie zostały „Zastrzeżone (...) dla organów innych władz publicznych”. Trudno przy tym wykazać, że zapewnienie szczególnej pozycji weteranom walk o niepodległość jest „Zaspokojeniem potrzeb wspólnoty samorządowej”"59, a więc stanowi jej zadanie własne w rozumieniu art. 165 ust. 1 Konstytucji RP. Kwestia prawnego uprzywilejowania weteranów nie jest nierozerwalnie związana $\mathrm{z}$ funkcjonowaniem samorządu terytorialnego i wykracza poza zakres podstawowych i powszechnych potrzeb jego mieszkańców. Taki stan rzeczy, prima facie, wskazywałby, że wyłącznym adresatem zobowiązań płynących z art. 19 Konstytucji RP są organy władzy publicznej. Zwrócić jednak należy uwagę, że przepis ten in principio odwołuje się do generalnego pojęcia Rzeczypospolitej Polskiej, a nie do którejś z wyszczególnionych kategorii organów wchodzących w zakres struktury państwa polskiego. Obowiązująca ustawa zasadnicza ustanawia ustrój, który ma charakter integracyjny, włączający poszczególne kategorie podmiotów obrotu prawnego, w tym również samorząd terytorialny, do całokształtu funkcjonowania państwa polskiego ${ }^{60}$. Daje temu wyraz również preambuła, adresując stosowne wezwanie do „Wszystkich, którzy (...) tę Konstytucję będą stosowali”. Jeżeli zaś przypomnieć, że samorząd terytorialny jest niezbędnym elementem ustrojowym państwa polskiego (art. 15 Konstytucji RP) ${ }^{61}$, to spoczywa na nim, podobnie jak na innych

\footnotetext{
58 M. Jabłoński, Prawo weteranów, op. cit., s. 607.

59 O kategoriach zadań samorządu terytorialnego zob. Z. Leoński, Samorząd terytorialny $w$ RP, Warszawa 2004, s. 28-29.

${ }_{61}$ Wyrok TK z 18 lutego 2003 r., sygn. akt K 24/02, OTK-A ZU 2003, nr 2, poz. 11.
} 
podmiotach współtworzących państwo, konieczność zapewnienia szczególnej opieki weteranom walk o niepodległość. Z perspektywy zastrzeżenia zawartego w art. 165 ust. 1 Konstytucji RP nie jest to jednak obowiązek bezwzględny, jak to ma miejsce w odniesieniu do organów władzy państwowej, a jedynie przewiduje dla samorządu prawną możliwość - i zarazem podstawę prawną - realizowania działań o takim charakterze.

Wreszcie trzecią grupą potencjalnych adresatów zobowiązania wynikającego $\mathrm{z}$ omawianego przepisu mogą być obywatele. $\mathrm{Z}$ pewnością ta kategoria podmiotów stanowi substrat osobowy państwa polskiego, a więc wchodzi w zakres treściowy pojęcia Rzeczypospolitej Polskiej, która stanowi ich dobro wspólne (art. 1 Konstytucji RP) ${ }^{62}$. Zbiorowość obywateli ustanawia naród w rozumieniu art. 4 Konstytucji RP. Z kolei preambuła wskazuje „Naród Polski” jako podmiot „wdzięczny naszym przodkom (...) za walkę okupioną ogromnymi ofiarami”. Przytoczone postanowienia nie są jednak na tyle jeszcze precyzyjne, aby dostarczały argumentu za nałożeniem na obywateli, na poziomie konstytucyjnym, prawnego obowiązku otoczenia weteranów szczególną opieką. Przewidzenie takiej powinności, zasadniczo w postaci ewentualnego obowiązku daninowego (art. 84 Konstytucji RP), pozostawione jest ustawodawcy zwykłemu ${ }^{63}$. Funkcjonowanie wspólnoty politycznej państwa nie poprzestaje jednak na katalogu obowiązków o charakterze prawnym, a przede wszystkim związane jest z realizacją „zasady sprawiedliwości społecznej” (art. 2 Konstytucji RP) oraz ulega zogniskowaniu w sferze rozumienia państwa jako „dobra wspólnego wszystkich obywateli" (art. 1 Konstytucji RP). Kwestia odpowiedniej troski o weteranów, pamięci o ich dokonaniach, oddawania należytego szacunku oraz zapewnienie odpowiedniego poziomu opieki społecznej i medycznej staje się zatem - z perspektywy obu wymienionych reguł konstytucyjnych - obowiązkiem natury moralnej lub etycznej, wykonywanym wobec osób, dzięki którym można mówić o współczesnym kształcie państwa polskiego (por. w szczególności art. 5 Konstytucji RP i postanowienia preambuły). Zdaje się, że refleksja dotycząca tych założeń nie jest jeszcze do końca pogłębiona, zarówno w sferze analizy prawnej, jak też codziennej praktyki społecznej i politycznej.

Przypomnijmy, że art. 19 Konstytucji RP nakazuje „otoczyć szczególną opieką weteranów walk o niepodległość”. Pojęcie „opieki” niesie ze sobą istotną trudność we wskazaniu zakresu pożądanego działania państwa. Ze względu jednak na kontekst przepisu i fakt, że dotyczy on weteranów, a więc osób, które zazwyczaj ponosiły określone szkody, można wskazać na kilka potencjalnych

62 M. Piechowiak, Dobro wspólne, op. cit., s. 267-273, 434.

63 Ustawową limitację podatków wskazuje T. Dębowska-Romanowska, Pojęcie podatków $i$ innych danin publicznych $w$ świetle konstytucji [w:] Stanowienie i stosowanie prawa podatkowego. Ksiega jubileuszowa Profesora Ryszarda Mastalskiego, red. W. Miemiec, Wrocław 2009, s. 111. 
form działania państwa, przede wszystkim o charakterze socjalnym i kompensacyjnym $^{64}$. Przyjęty kierunek interpretacyjny podyktowany jest tym, że omawiany przepis, odczytywany in fine, odwołuje się do znanej systemowi prawnemu kategorii „inwalidów wojennych”65, a więc osób szczególnie poszkodowanych, a równocześnie podmiotów wymagających odpowiedniej troski oraz zabezpieczenia potrzeb wynikających z ich niepełnosprawności. Przede wszystkim więc opieka ta może przybrać postać właściwego zaopatrzenia w świadczenia o charakterze społecznym lub medycznym. Pożądane byłoby w tym zakresie m.in. przyznawanie emerytur i rent lub też podwyższenie ich wymiaru, oferowanie dodatkowych świadczeń społecznych o charakterze pieniężnym lub rzeczowym. Niezbędna jest także kwestia odpowiedniej opieki bezpośredniej, świadczonej przez wyspecjalizowany personel socjalny lub terapeutyczny. W odniesieniu do sfery medycznej istotne może być zapewnienie pierwszeństwa dostępu do leczenia, także klinicznego i specjalistycznego, całkowita lub chociażby częściowa refundacja środków farmaceutycznych, jak również wprowadzenie dodatkowych form zaopatrzenia medycznego. Płaszczyzna pomocy materialnej jest niezwykle ważna $^{66}$. Jednym z wymiarów „otoczenia opieką” może być także należyte uszanowanie weteranów w sferze publicznej, związane z oddawaniem im społecznego poważania, w tym dbałość o miejsca pochówku oraz materialne świadectwa ich zaangażowania.

Dotychczas wskazane obszary działania państwa mają charakter jedynie przykładowy i dowodzą, że zakres normowania art. 19 Konstytucji RP jest bardzo szeroki, a sam sposób jego wysłowienia kłopotliwy interpretacyjnie ${ }^{67}$. Powoduje to również dużą swobodę po stronie ustawodawcy ${ }^{68}$, który jednak związany jest bieżącymi możliwościami budżetowymi, które de facto każdorazowo będą determinowały zakres świadczeń oferowanych weteranom ${ }^{69}$. Wydaje się jednak, że działania w tej sferze nie wyczerpują istoty problemu. Analizowany przepis posługuje się bowiem nie tylko pojęciem konieczności „otaczania opieką” kombatantów, ale dodatkowo opatruje ten zwrot stwierdzeniem, że opieka ta ma być „szczególna”. Nie jest zatem wypełnieniem zobowiązania wynikającego z art. 19

64 K. Ślebzak, Komentarz do art. 19, op. cit., s. 496, 498-499.

65 Pojęcie to ma „ustabilizowane znaczenie prawne”, co wydaje się determinować jego rozumienie na gruncie samej Konstytucji, jak również ustaw zwykłych - zob. M. Zubik, Podmioty konstytucyjnych wolności, op. cit., s. 33-34.

66 Ujęcie „szczególnej opieki” wyłącznie w kategoriach mecenatu materialnego przedstawia M. Jabłoński, Prawo weteranów, op. cit., s. 610 i 617.

67 Przykładem tego ma być zwrot „specjalna opieka”, zob. M. Zubik, Podmioty konstytucyjnych wolności, op. cit., s. 36.

68 Wyrok TK z 21 czerwca 2000 r., sygn. akt K 2/99, OTK 2000, nr 5, poz. 139.

69 Choć już chyba nie w tak ekstremalnym znaczeniu, na jakie powołuje się TK, przyjmując jako granicę tych wydatków cezurę z art. 216 ust. 5 Konstytucji. Zob. wyrok TK z 9 marca 2004 r., sygn. akt K 12/02. 
Konstytucji RP zagwarantowanie weteranom określonych praw lub zwolnienie ich z obowiązków o charakterze powszechnym. Konieczne jest ich specyficzne potraktowanie, zastrzeżenie dla nich takiego stopnia uprzywilejowania, jaki nie jest dostępny dla innych uczestników obrotu prawnego ${ }^{70}$. Przyjmuje się, że „opieka nad weteranami musi być (...) szersza i co do zasady intensywniejsza" ${ }^{\prime 1}$ niż w zwykłych warunkach. Chodzi tu więc o sięgnięcie po takie mechanizmy, które będą wyróżniały weteranów na tle powszechnych uwarunkowań systemowych, choć - co oczywiste - nie mogą one przekraczać rozsądnych granic sprawiedliwości społecznej ${ }^{72}$. Już tylko z tej racji, że danej osobie przysługuje status weterana walk o niepodległość, ustawodawca może sięgnąć po instrumenty o charakterze ekstraordynaryjnym, przydając tym samym jej szczególnych uprawnień, czego nie mógłby uczynić w odniesieniu do innych kategorii podmiotów ${ }^{73}$.

\section{Rekomendacje}

Przede wszystkim trzeba wskazać, że otoczenie prawne art. 19 Konstytucji RP, które realizuje ten przepis na poziomie ustawowym, jest bardzo bogate. Obfitość taką należy docenić, świadczy ona bowiem o dostrzeżeniu przez prawodawcę doniosłości materii, a tym samym może stanowić o jakości wykonywania przez państwo polskie obowiązku wobec swoich weteranów. Powstanie wydzielonej gałęzi „prawa weteranów” jest zjawiskiem ze wszech miar korzystnym, zarówno w wymiarze indywidualnym, jak również na płaszczyźnie publicznej. Wielopostaciowość regulacji dopomina się jednak, de lege ferenda, stworzenia jednolitej kodyfikacji. Pozwoliłoby to na usunięcie nie tylko powstających wątpliwości interpretacyjnych, ale przede wszystkim dało jasne świadectwo zaangażowania państwa w sferę zapewnienia szczególnej opieki nad weteranami.

Po drugie, nie może ujść uwadze fakt, że analizowany przepis ustawy zasadniczej nie tylko wysławia ogólną zasadę ustrojową, ale ma również charakter dyrektywy programowej i interpretacyjnej. Sankcjonuje on także określone prawo podmiotowe. Zdefiniowanie przez ustawodawcę faktycznego wymiaru uprzywilejowania weteranów zawsze jednak będzie efektem pewnego kompromisu między obowiązkiem „szczególnej opieki”, a możliwościami budżetowymi państwa. Są to realia, z którymi trudno dyskutować. Wydaje się jednak, że poza sferą materialną istnieje inna jeszcze płaszczyzna praktycznie przez prawodawcę pominięta. Chodzi tu mianowicie o zachęcenie do publicznego uszanowania weteranów, okazywania im należytego respektu. Powinno to być, przy wykorzystaniu odpo-

70 Odmiennie M. Jabłoński, Prawo weteranów, op. cit., s. 611.

71 Odmiennie ibidem, s. 614.

72 Wyrok TK z 9 marca 2004 r., sygn. akt K 12/02.

73 Wyrok TK z 15 kwietnia 2003 r., sygn. akt SK 4/02. 
wiednich instrumentów prawnych, realizowane zarówno w wymiarze symbolicznym, jak też edukacyjnym. Ten horyzont wydaje się być aż do dziś niedostatecznie uwzględniony, nie tylko na płaszczyźnie praktycznej, ale również regulacyjnej.

Wreszcie trzecia obserwacja, mająca bardziej naturę praktyczną, związana jest jednak z temporalnym charakterem funkcjonowania art. 19 Konstytucji RP. Jego zakres podmiotowy obejmuje, co prawda, współczesnych nam weteranów walk poza granicami kraju, niemniej zasadnicza część jego adresatów, a więc narodowych bohaterów, podejmowała swoje działania w czasach już nam odległych, tj. na frontach II wojny światowej oraz okresie powojennym, jak również w czasie tzw. karnawału Solidarności. To rodzi postulat możliwie niezwłocznego skupienia wysiłku administracyjnego oraz zogniskowania środków budżetowych w perspektywie najbliższej dekady lub nawet dwóch. Po jej upływie znaczna część osób uprawnionych, ze względów oczywistych, nie skorzysta z należnego im uprzywilejowania. Pozostanie oczywiście kwestia narracyjna polityki pamięci, związanej z kultywowaniem wzorców oraz odwoływaniem się do pewnej symboliki, nie jest to już jednak pierwszoplanowa, choć nadal bardzo ważna, treść reguły zawartej w art. 19 Konstytucji RP.

\section{Bibliografia}

Banaszak B., Konstytucja Rzeczypospolitej Polskiej. Komentarz, Warszawa 2009.

Błachucki M., Ciagłość i tożsamość prawna państwa polskiego, „Przegląd Prawniczy Uniwersytetu Warszawskiego" 2004, nr 1.

Boć J., Komentarz do art. 19 [w:] Konstytucje Rzeczypospolitej oraz komentarz do Konstytucji RP z 1997 roku, red. J. Boć, Wrocław 1998.

Brzozowski W., Bezstronność światopoglądowa władz publicznych w Konstytucji RP, Warszawa 2011.

Complak K., Komentarz do art. 19 [w:] Konstytucja Rzeczypospolitej Polskiej. Komentarz, red. M. Haczkowska, Warszawa 2014.

Dębowska-Romanowska T., Pojęcie podatków i innych danin publicznych w świetle konstytucji [w:] Stanowienie i stosowanie prawa podatkowego. Ksiega jubileuszowa Profesora Ryszarda Mastalskiego, red. W. Miemiec, Wrocław 2009.

Garlicki L., Komentarz do rozdziału II Wolności, prawa i obowiązki człowieka i obywatela [w:] Konstytucja Rzeczpospolitej Polskiej. Komentarz, t. III, red. L. Garlicki, Warszawa 2003.

Garlicki L., Derlatka M., Komentarz do art. 19 [w:] Konstytucja Rzeczypospolitej Polskiej. Komentarz, t. I, red. L. Garlicki, M. Zubik, Warszawa 2016.

Garlicki L., Polskie prawo konstytucyjne. Zarys wykładu, Warszawa 1999.

Jabłoński M., Prawo weteranów do specjalnej opieki ze strony państwa [w:] Realizacja i ochrona konstytucyjnych wolności i praw jednostki w polskim porządku prawnym, red. M. Jabłoński, Wrocław 2014. 
Kulka G., Nadawanie, pozbawianie i przywracanie obywatelstwa polskiego w czasie II wojny światowej, „Czasopismo Prawno-Historyczne” 2011, nr 1.

Leoński Z., Samorząd terytorialny w RP, Warszawa 2004.

Piechowiak M., Dobro wspólne jako fundament polskiego porzadku konstytucyjnego, Warszawa 2012.

Schwarzgruber M., Weteran czy kombatant, „Polska Zbrojna” 2013, nr 10.

Skrzydło W., Konstytucja Rzeczypospolitej Polskiej. Komentarz, Warszawa 2013.

Szymańska S., Realizacja ustawy o kombatantach $w$ świetle orzecznictwa SN, „Przegląd Sądowy" 1998, nr 2.

Ślebzak K., Komentarz do art. 19 [w:] Konstytucja RP, t. I, Komentarz. Art. 1-86, red. M. Safjan, L. Bosek, Warszawa 2016.

Zubik M., Podmioty konstytucyjnych wolności, praw i obowiązków, „Przegląd Legislacyjny" 2007 , nr 2. 

\begin{tabular}{l|l}
2 & OPINIE BAS
\end{tabular}

\begin{tabular}{l|l} 
A & ZAGADNIENIA PRAWA \\
KONSTYTUCYJNEGO
\end{tabular} 



\title{
Wykładnia art. 47 ust. 2 pkt 1 regulaminu Sejmu - tryb rozpatrywania poprawek w komisjach ${ }^{1}$
}

\begin{abstract}
Interpretation of the Article 47 para. 2 subpara. 1 of the Standing Orders of the Sejm the procedure for considering amendments in committees (WAKiU-876/18): The analysis concerns the issue of whether a committee considering, based on the indicated provision, amendments submitted during the second reading, should vote on their acceptance or rejection separately for each amendment, or if it is possible, after consideration of the amendment, to automatically (without separate vote) draw a recommendation concerning other amendments, in case it is a logical consequence of acceptance or rejection of the former amendment. The author assessed that there are no obstacles to apply, at this stage of legislative work, per analogiam the institution of the third-reading voting applied in the first instance to the "most far-reaching amendments", i.e. those whose adoption or rejection determines decision concerning other amendments.
\end{abstract}

Keywords: committee of the Sejm, amendment, legislative procedure

Słowa kluczowe: komisja sejmowa, poprawka, procedura ustawodawcza

\section{Przedmiot opinii}

Przedmiotem niniejszej opinii jest wykładnia art. 47 ust. 2 pkt 1 regulaminu Sejmu, zgodnie z którym: [k]omisje po rozpatrzeniu z udziałem wnioskodawców zgłoszonych poprawek $i$ wniosków, przedkładaja Sejmowi dodatkowe sprawo$z$ danie, $w$ którym przedstawiaja wniosek o ich przyjęcie lub odrzucenie; przepisy art. 43 ust. 6 stosuje się odpowiednio, a konkretnie odpowiedź na pytanie: „czy komisja, rozpatrując na podstawie art. 47 ust. 2 pkt 1 regulaminu Sejmu poprawki zgłoszone w drugim czytaniu, powinna głosować wnioski o ich przyjęcie albo odrzucenie odrębnie dla każdej poprawki, czy też możliwe jest, po rozpatrzeniu poprawki, automatyczne (bez odrębnego głosowania) przyjęcie wniosków dla

1 Opinia prawna w sprawie wykładni art. 47 ust. 2 pkt 1 regulaminu Sejmu sporządzona 29 maja 2018 r. na zlecenie dyrektora Biura Legislacyjnego; BAS-WAKiU 876/18. 
innych poprawek w przypadku, gdy jest to logiczna konsekwencja przyjęcia albo odrzucenia”.

\section{Uwagi ogólne}

Analizowany problem związany jest z komisyjnym postępowaniem w sprawie opracowania sprawozdania dodatkowego nad projektem, tj. jednej z dwóch (obok postępowania w sprawie tzw. sprawozdania poprawionego) instytucji prawnych uregulowanych w art. 47 regulaminu Sejmu. Treścią sprawozdania dodatkowego jest zbiór rekomendacji komisji dla Sejmu (przyjąć bądź odrzucić) odnośnie do poprawek i wniosków ${ }^{2}$ wniesionych w toku drugiego czytania. Faza ta następuje więc między drugim a trzecim czytaniem projektu ustaw, przy czym nie jest ona obligatoryjna. Zgodnie z art. 47 ust. 1 regulaminu Sejmu Sejm może bowiem, w razie zgłoszenia w drugim czytaniu nowych poprawek i wniosków, postanowić o niekierowaniu projektu do komisji, jednak w praktyce zdarza się to sporadycznie ${ }^{3}$.

Jedynym zadaniem komisji w fazie opracowywania sprawozdania dodatkowego jest zaopiniowanie zgłoszonych w drugim czytaniu poprawek i wniosków, co w szczególności oznacza zakaz modyfikowania ich podczas prac komisyjnych (z wyjątkiem ewentualnego wycofania przed rozpatrzeniem przez komisję) czy wnoszenia dodatkowych poprawek i wniosków ${ }^{4}$. Informacja o stanowisku komisji zawartym w sprawozdaniu dodatkowym jest przedstawiana izbie przez posła-sprawozdawcę podczas trzeciego czytania, przed przystąpieniem do głosowań (art. 49 pkt 1 regulaminu Sejmu), przy czym w praktyce informacja ta jest lakoniczna ${ }^{5}$. Okoliczność ta nie budzi zastrzeżeń, skoro dodatkowe sprawozdanie komisji jest przed jego rozpatrzeniem doręczane posłom (art. 47 ust. 6 regulaminu Sejmu).

2 De facto wyłącznie wniosku o odrzucenie projektu ustawy w całości.

3 Zob. P. Chybalski, Uwagi do art. 47 [w:] Komentarz do regulaminu Sejmu, red. A. Szmyt, Warszawa 2018, s. 319.

4 W. Odrowąż-Sypniewski, Dopuszczalność głosowania przez komisje poprawki zgłoszonej przez posła $w$ trakcie drugiego czytania, mimo że została ona na posiedzeniu komisji wycofana przez autora [w:] Regulamin Sejmu w opiniach Biura Analiz Sejmowych, t. I, red. W. Odrowąż-Sypniewski, Warszawa 2010. Zob. też nieco inaczej M. Zubik, Dopuszczalność wycofania poprawki w trzecim czytaniu [w:] Regulamin Sejmu w opiniach Biura Analiz Sejmowych, t. I, red. W. Odrowąż-Sypniewski, Warszawa 2010.

5 P. Chybalski, Uwagi do art. 47, op. cit., s. 323, 324. 


\section{Sposób rozpatrzenia poprawek i wniosków w fazie opracowywania sprawozdania dodatkowego}

Przepisy regulaminu $\mathrm{w}$ niewielkim zakresie określają sposób postępowania komisji w toku prac nad zaopiniowaniem poprawek i wniosków wniesionych $\mathrm{w}$ trakcie drugiego czytania. Po pierwsze, $\mathrm{z}$ analizowanego art. 47 ust. 2 pkt regulaminu Sejmu wynika, jak się wydaje bezspornie, że obowiązek rozpatrzenia w celu określenia rekomendacji dla Sejmu odnosi się do wszystkich ww. poprawek i wniosków. Po drugie, zgodnie z art. 47 ust. 4 regulaminu Sejmu komisja może nie rozpatrywać poprawki zgłoszonej przez wnioskodawcę $\mathrm{w}$ razie nieobecności wnioskodawcy lub jeżeli poprawka nie spełnia wymagań, o których mowa w art. 44 ust. 2, tj. jeżeli nie została - po ustnym zgłoszeniu w toku drugiego czytania - wniesiona w formie pisemnej bądź wnioskodawcy nie wskazali wynikających z poprawki konsekwencji dla tekstu projektu ustawy. W pozostałym zakresie, jak zauważył W. Odrowąż-Sypniewski, określenie trybu (sposobu) rozpatrzenia poprawek i wniosków „należy do autonomii proceduralnej komisji”. Taki stan rzeczy oznacza, iż komisji przysługuje znaczny stopień swobody w zakresie organizacji postępowania w sprawie opracowania sprawozdania dodatkowego - oczywiście przy zachowaniu ogólnych zasad funkcjonowania komisji sejmowych uregulowanych w szczególności w dziale II rozdziale 14 regulaminu. Przykładowo dopuszczalne jest kierowanie poprawek i wniosków do dodatkowego zaopiniowania przez podkomisję . $^{7}$

Powyższe uwagi rzutują na sposób odpowiedzi na sformułowane we wstępie pytanie. Jakkolwiek, jak już wspomniano, na komisji ciąży obowiązek ustosunkowania się do wszystkich poprawek i wniosków zgłoszonych podczas drugiego czytania, to regulamin nie przesądza, czy konieczne jest osobne rozpatrzenie (w tym przegłosowanie określonej rekomendacji) każdej z poprawek bądź wniosku. Oczywiście taki sposób ich rozpatrzenia należy uznać za domyślny (wyjściowy), lecz w moim przekonaniu nie ma przeszkód, aby w drodze analogii zastosować używaną podczas głosowań przeprowadzanych w trzecim czytaniu instytucję rozpatrywania w pierwszej kolejności „poprawek najdalej idących”, tj. takich, których przyjęcie lub odrzucenie rozstrzyga o innych poprawkach (art. 50 ust. 1 pkt 2 regulaminu Sejmu). Taki sposób rozpatrywania nie oznacza, że część poprawek czy wniosków nie zostaje poddana rozpatrzeniu, lecz że zostają one rozpatrzone w sposób dorozumiany (a jednocześnie niebudzący wątpliwości) w wyniku określonego rozstrzygnięcia co do „poprawki najdalej idącej”. Należy przy tym zastrzec, że przesłanką zastosowania omawianej instytucji proceduralnej w toku prac komisyjnych - tak jak i w trzecim pytaniu - jest tożsamość

$6 \quad$ W. Odrowąż-Sypniewski, Dopuszczalność głosowania, op. cit., s. 352.

7 P. Chybalski, $W$ sprawie możliwości powierzenia podkomisjom sejmowym niektórych zadań związanych z funkcją ustawodawcza, „Przegląd Sejmowy” 2012, nr 1, s. 96. 
materii określonych poprawek, co czyni je poprawkami konkurencyjnymi, tj. zakładającymi zróżnicowane sposoby regulacji określonej materii. Ustalenie, która z poddanych rozpatrzeniu komisyjnemu poprawek jest „najdalej idąca”, wydaje się stanowić czynność o charakterze „technicznym”, co oznacza, że wymaga ona podjęcia oceny na tyle zobiektywizowanej, że nie powinna stanowić źródła kontrowersji wśród członków komisji ${ }^{8}$.

Za dopuszczalnością zastosowania powyższego rozwiązania w toku prac komisyjnych nad poprawkami i wnioskami wniesionymi w toku drugiego czytania przemawiają dodatkowo dwie okoliczności. Po pierwsze, instytucja „poprawki najdalej idącej” jest już w analizowanej fazie prac ustawodawczych niekiedy stosowana, w szczególności w toku postępowania w Komisji Finansów Publicznych nad poprawkami do projektu ustawy budżetowej. Praktyka ta nie budzi wątpliwości, co, uwzględniając fakt, iż ten aspekt prac budżetowych nie został w regulaminie Sejmu (dział II rozdział 6) uregulowany odmiennie od zasad dotyczących tzw. zwykłego trybu ustawodawczego, oznacza, że akceptuje się opisywany sposób rozpatrzenia poprawek i wniosków podczas prac nad sprawozdaniem dodatkowym. Tym samym nie sposób zanegować stosowanie go w toku postępowania $\mathrm{z}$ innymi projektami niż projekt ustawy budżetowej.

Po drugie, ewentualne przyjęcie omawianego sposobu rozpatrywania przez komisję poprawek i wniosków wydaje się znajdować uzasadnienie funkcjonalne. Bezwzględny nakaz osobnego ustosunkowania się przez komisję do każdej z poprawek czy wniosku mógłby doprowadzić do sytuacji jednolitego zaopiniowania poprawek konkurencyjnych. Taki stan rzeczy, w szczególności przy pozytywnej rekomendacji komisyjnej odnośnie do takich poprawek, mógłby potencjalnie sprzyjać wystąpieniu sytuacji, w której Sejm przyjmie poprawki wzajemnie się wykluczające, burząc tym samym spójność treści uchwalanej ustawy. Wreszcie nie do przecenienia jest fakt, iż, jak wskazuje dotychczasowa praktyka, instytucja „poprawki najdalej idącej” sprzyja skutecznemu przeciwdziałaniu obstrukcji parlamentarnej polegającej na wnoszeniu znacznej liczby poprawek wyłącznie w celu spowolnienia prac ustawodawczych ${ }^{9}$.

8 Na marginesie warto odnotować, że na sformułowany wniosek nie ma wpływu tzw. uchwała wykładnicza Prezydium Sejmu z grudnia 2016 r. (uchwała nr 45 z 16 grudnia 2016 r. w sprawie wykładni art. 184 ust. 3 pkt 9 regulaminu Sejmu), w której de facto dopuszczono tzw. blokowanie poprawek, tj. łączne głosowanie poprawek, które zostały jednolicie zaopiniowane przez komisję w omawianej fazie prac. Uchwała ta budzi istotne zastrzeżenia prawne, zob. P. Chybalski, Uwagi do art. 50 [w:] Komentarz do regulaminu Sejmu, red. A. Szmyt, Warszawa 2018, s. 328-330.

9 Zob. zwłaszcza opis casusu rozpatrzenia poprawek do projektu ustawy budżetowej na 2013 r., P. Chybalski, Uwagi do art. 50, op. cit., s. 328. 


\section{Podsumowanie}

Jakkolwiek osobne rozpatrzenie każdej z poprawek bądź wniosku należy uznać za domyślny (wyjściowy) sposób postępowania komisji w toku prac nad sprawozdaniem dodatkowym, to nie ma przeszkód, aby w fazie prac ustawodawczych między drugim a trzecim czytaniem w drodze analogii zastosować wykorzystywaną podczas głosowań przeprowadzanych w trzecim czytaniu instytucję rozpatrywania w pierwszej kolejności „poprawek najdalej idących”, tj. takich, których przyjęcie lub odrzucenie rozstrzyga o innych poprawkach (art. 50 ust. 1 pkt 2 regulaminu Sejmu). Taki sposób rozpatrzenia nie oznacza, że część poprawek czy wniosków nie zostaje poddana rozpatrzeniu, lecz że zostają one rozpatrzone w sposób dorozumiany (a jednocześnie niebudzący wątpliwości) w wyniku określonego rozstrzygnięcia co do „poprawki najdalej idącej”.

\section{Bibliografia}

Chybalski P., Uwagi do art. 47; uwagi do art. 50 [w:] Komentarz do regulaminu Sejmu, red. A. Szmyt, Warszawa 2018.

Chybalski P., W sprawie możliwości powierzenia podkomisjom sejmowym niektórych zadań związanych z funkcja ustawodawcza, „Przegląd Sejmowy” 2012, nr 1.

Odrowąż-Sypniewski W., Dopuszczalność głosowania przez komisje poprawki zgłoszonej przez posła $w$ trakcie drugiego czytania, mimo że została ona na posiedzeniu komisji wycofana przez autora [w:] Regulamin Sejmu w opiniach Biura Analiz Sejmowych, t. I, red. W. Odrowąż-Sypniewski, Warszawa 2010.

Zubik M., Dopuszczalność wycofania poprawki w trzecim czytaniu [w:] Regulamin Sejmu w opiniach Biura Analiz Sejmowych, t. I, red. W. Odrowąż-Sypniewski, Warszawa 2010 . 


\section{Wykładnia art. 152 ust. 5 regulaminu Sejmu - powiadomienie członków komisji o posiedzeniu komisji ${ }^{1}$}

Interpretation of Article 152 para. 5 of the Standing Orders of the Sejm - notification to committee members about a committee sitting (WAKiU-1461/18): Notification to committee members about a committee sitting (date and agenda) should take place at least three days before the sitting, unless the meeting was convened as a result of decisions taken at the sitting of the Sejm. The discussed rule allows each member of the committee to plan a calendar of activities taking into account all individual responsibilities. The author emphasizes that with Article 152 para. 5 of the Standing Orders of the Sejm causes a few interpretation concerns, what indicates a need of its amendment.

Keywords: committee of the Sejm, Standing Orders of the Sejm

Słowa kluczowe: komisja sejmowa, regulamin Sejmu

Ekspert ds. legislacji BAS; wojciech.sypniewski@sejm.gov.pl.

\section{Przedmiot opinii}

Przedmiotem opinii jest interpretacja art. 152 ust. 5 regulaminu Sejmu.

\section{Model normatywny zawiadamiania o terminie i porządku dziennym posiedzenia}

W myśl regulaminu Sejmu posiedzenia komisji odbywają się w terminach określonych przez samą komisję, jej prezydium lub przewodniczącego (art. 152 ust. 1 regulaminu Sejmu). Porządek dzienny posiedzenia komisji ustala prezydium, które powinno w tym zakresie brać pod uwagę wnioski klubów i kół poselskich

Opinia prawna na temat wykładni art. 152 ust. 5 regulaminu Sejmu sporządzona 14 czerwca 2018 r. na zlecenie przewodniczącego Komisji Regulaminowej, Spraw Poselskich i Immunitetowych; BAS-WAKiU 1461/18. 
oraz poszczególnych posłów (art. 150 ust. 2). Od powyższych zasad regulamin przewiduje dwa wyjątki. Po pierwsze, Prezydium Sejmu może zwołać posiedzenie komisji w celu rozpatrzenia określonej sprawy, wyznaczając jego termin (art. 152 ust. 3). Po drugie, na pisemny wniosek co najmniej jednej trzeciej ogólnej liczby członków komisji przewodniczący komisji obowiązany jest zwołać posiedzenie komisji w celu rozpatrzenia określonej sprawy. Zwołując posiedzenie $\mathrm{w}$ tym trybie, przewodniczący komisji wyznacza termin posiedzenia tak, aby odbyło się ono w terminie $30 \mathrm{dni}$ od dnia złożenia wniosku (art. 152 ust. 2).

Artykuł 152 ust. 5 regulaminu Sejmu stanowi że: [o] terminie i porzadku dziennym posiedzenia komisji zawiadamia się członków komisji, Prezydium Sej$m u$, Najwyższa Izbę Kontroli oraz zainteresowane organy państwowe. Zawiadomienie członków komisji powinno nastąpić co najmniej na 3 dni przed posiedzeniem komisji, na zasadach i w trybie określonych przez Prezydium Sejmu, chyba że posiedzenie zwołane zostało w wyniku decyzji podjętych na posiedzeniu Sejmu. Pamiętać zarazem należy, że zgodnie z art. 152 ust. 3 regulaminu Sejmu: [o] terminie i porzadku dziennym posiedzenia komisji przewodniczacy komisji zawiadamia Marszałka Sejmu, który może nie wyrazić zgody na odbycie posiedzenia komisji.

Artykuł 152 ust. 5 wyraża trzy zasady. Pierwsze zdanie ustanawia (1) obowiązek zawiadomienia o terminie i porządku dziennym posiedzenia członków komisji oraz wskazanych podmiotów. Drugie zdanie określa (2) termin zawiadomienia członków komisji (co najmniej na 3 dni przed posiedzeniem komisji, chyba że posiedzenie zwołane zostało w wyniku decyzji podjętych na posiedzeniu Sejmu), oraz (3) ustanawia podstawę prawną dla sformułowania przez Prezydium Sejmu zasad i trybu wykonywania tego obowiązku.

Pierwsza zasada - wyznaczenie kręgu podmiotów, które powinny zostać zawiadomione o posiedzeniu komisji - może rodzić trojakiego rodzaju wątpliwości. Po pierwsze, przepis ten nie rozstrzyga wprost, kto jest podmiotem tego obowiązku, tzn. na którym organie komisji ciąży wymóg jego wykonywania. Skoro jednak twórcy regulaminu Sejmu powierzyli przewodniczącemu komisji obowiązek zawiadomienia Marszałka Sejmu o terminie i porządku dziennym posiedzenia komisji (art. 152 ust. 3), to na tym samym organie ciążyć będzie wymóg zawiadomienia o posiedzeniu komisji podmiotów wymienionych w tym przepisie. Jedynym wyjątkiem będzie przypadek, w którym posiedzenie komisji zwoływane jest przez Prezydium Sejmu, wówczas obowiązek zawiadomienia członków komisji oraz innych podmiotów wymienionych w art. 152 ust. 5 zdanie pierwsze spadnie na ten organ. Wątpliwości budzi sposób wyrażenia obowiązku zawiadamiania Najwyższej Izby Kontroli o posiedzeniu komisji. Z treści analizowanego przepisu wynika, że obowiązek ten ma charakter uniwersalny i dotyczy wszystkich posiedzeń komisji sejmowych. Mając na uwadze, że posiedzenia komisji służą realizacji różnych funkcji Sejmu, należałoby de lege lata ograniczyć zakres tego obowiązku. Trzecią kwestią są dylematy interpretacyjne związane $\mathrm{z}$ formułą „zainteresowane organy państwowe”. Przyjąć należy, że chodzi o orga- 
ny państwowe, których właściwość obejmuje problematykę objętą porządkiem dziennym planowanego posiedzenia komisji. Wybór konkretnych podmiotów dokonywany jest przez prezydium komisji w ramach wykonywania kompetencji „czuwania nad przygotowaniem posiedzeń” i „zapewnienia członkom komisji należycie przygotowanych materiałów” (art. 150 ust. 1 pkt 3-4 regulaminu Sejmu) ${ }^{2}$.

Wyrażana w drugim zdaniu zasada, która określa termin zawiadomienia członków komisji o posiedzeniu komisji, nie powinna w praktyce budzić szerszych wątpliwości (clara non sunt interpretanda est). Zawiadomienie członków komisji o posiedzeniu komisji (terminie i porządku dziennym) powinno nastąpić co najmniej na trzy dni przed posiedzeniem komisji, chyba że posiedzenie zwołane zostało w wyniku decyzji podjętych na posiedzeniu Sejmu. W omawianym przypadku, wobec braku określenia w regulaminie Sejmu zasad liczenia terminów oraz braku odesłania do innych procedur, które określałyby te zasady, należy przyjąć, że dla ustalenia sposobu obliczania tego terminu należy odwołać się do sensu semantycznego użytych słów ${ }^{3}$. Oznacza to, że, co do zasady, informacja o terminie i porządku dziennym posiedzenia komisji powinna dotrzeć do wszystkich członków komisji nie później niż do końca dnia, który swoją datą poprzedza o trzy dni termin posiedzenia komisji.

Obowiązek ten stanowi istotną gwarancję swobody sprawowania mandatu poselskiego. Omawiana zasada pozwala każdemu członkowi komisji zaplanować kalendarz działań z uwzględnieniem wszystkich innych indywidualnych obowiązków. Posłowie są - zazwyczaj - członkami kilku komisji sejmowych, które niezależnie planują swoje posiedzenia, co w konsekwencji powoduje, że często odbywają się one w tym samym czasie (tzw. zbieg posiedzeń komisji). Obowiązek obecności na posiedzeniu komisji może konkurować z obowiązkiem udziału w posiedzeniu Sejmu lub jego organów, a także wykonywaniem innych obowiązków związanych ze sprawowaniem mandatu poselskiego (np. wyjazdy zagraniczne lub krajowe z polecenia Sejmu, Marszałka Sejmu czy udział w posiedzeniach organów, w których poseł reprezentuje Sejm - por. art. 7 ust. 8 pkt 3 regulaminu Sejmu). Swoboda wykonywania mandatu zakłada, że - w granicach przewidzianych regulaminem Sejmu - każdy parlamentarzysta autonomicznie dokonuje oceny doniosłości swoich poszczególnych zobowiązań i samodzielnie ustala kolejność ich realizacji. W konsekwencji posłowie - w sytuacji zbiegu posiedzeń komisji - samodzielnie dokonują wyboru tych posiedzeń, które w ich ocenie mają bardziej istotne znaczenie. Obowiązek powiadomienia o terminie posiedzenia i zaplanowanym porządku obrad stanowi zatem ważną gwarancję

2 P. Radziewicz, Uwagi do art. 152 [w:] Komentarz do Regulaminu Sejmu Rzeczypospolitej Polskiej, red. A. Szmyt, Warszawa 2018, s. 744.

3 Wyrażenie „co najmniej na dzień przed” oznacza dzień poprzedzający dzień zdarzenia; konsekwentnie wyrażenie „co najmniej na trzy dni przed” oznacza dzień, który datą poprzedza o trzy dni dzień zdarzenia. 
świadomego i odpowiedzialnego uczestnictwa w pracach Sejmu ${ }^{4}$. W piśmiennictwie wskazuje się, że: kwalifikowane naruszenie omawianej regulacji, w szczególności stosowanie jej $w$ celu eliminowania oponentów politycznych $z$ prac $w$ komisjipomimo tego że regulacja ta nie stanowi konstytucyjnego elementu postępowania ustawodawczego - mogłoby a casu ad casum skutkować zakwestionowaniem całej ustawy w postępowaniu przed Trybunałem Konstytucyjnym ze względu na wady proceduralne (zwłaszcza w warunkach kumulacji także innych nieprawidłowości $w$ trakcie procesu legislacyjnego $)^{5}$.

Odstąpienie od tej zasady jest możliwe jedynie w dwóch przypadkach: (1) gdy posiedzenie komisji zostało zwołane przez Prezydium Sejmu (zgodnie z art. 152 ust. 3 zdanie drugie nie stosuje się wówczas art. 152 ust. 5 zdanie drugie) oraz (2) w sytuacji, gdy posiedzenie zostało zwołane „w wyniku decyzji podjętych na posiedzeniu Sejmu". W rzeczywistości największe wątpliwości wiążą się ze sposobem rozumienia tego wyrażenia. Na gruncie teoretycznym jedynym rozstrzygnięciem Sejmu, które może rodzić skutek, o którym mowa w art. 152 ust. 5 zdanie drugie, jest sytuacja, w której Sejm, kierując projekt do komisji, wyznaczył im termin przedstawiania sprawozdania (art. 39 ust. 3 regulaminu Sejmu), którego zachowanie - $\mathrm{w}$ danych okolicznościach - wymaga przystąpienia przez komisję do rozpatrzenia projektu bezzwłocznie, co wiązać się musi z odstąpieniem od podstawowej zasady wyznaczającej termin zawiadamiania o posiedzeniu komisji. W praktyce jednak omawiana zasada interpretowana jest rozszerzająco i często polityczna potrzeba przyspieszenia prac legislacyjnych (np. szybkiego rozpatrzenia przez komisje poprawek zgłoszonych w drugim czytaniu) traktowana jest jako przesłanka legitymizująca odstępstwo od reguły ogólnej. De lege lata należałoby rozważyć modyfikację art. 152 ust. 5, która godziłaby funkcje gwarancyjne tego przepisu ze względami pragmatyki politycznej.

Artykuł 152 ust. 5 formułuje również upoważnienie dla Prezydium Sejmu do określenia zasad i trybu zawiadamiania członków komisji o terminie i porządku dziennym posiedzenia. Wykonanie tego upoważnienia powinno przyjmować formę uchwały, zaś upoważniony organ, konkretyzując postanowienia art. 152 ust. 5, jest nimi związany (Prezydium Sejmu nie mogłoby w uchwale określić innego terminu zawiadamiania o posiedzeniu komisji niż termin przyjęty w tym przepisie). W obecnym stanie prawnym omawiane kwestie określa uchwała Prezydium Sejmu z 3 sierpnia 2010 r. w sprawie zasad i trybu zawiadamiania członków komisji sejmowych o posiedzeniach komisji (uwzględniająca zmianę wprowadzoną uchwałą $\mathrm{nr} 5 \mathrm{z} 5$ marca 2013 r.). Zgodnie z $\$ 1$ ust. 1 tego aktu zawiadomienie członków komisji sejmowej o posiedzeniu komisji może być

4 W. Odrowąż-Sypniewski, Opinia prawna w sprawie trybu ustalania porządku dziennego posiedzenia komisji sejmowej, z 25 kwietnia 2012 r., BAS-WAUiP 1027/12, niepubl.; P. Radziewicz, Uwagi do art. 152, op. cit., s. 744.

5 P. Radziewicz, Uwagi do art. 152, op. cit. 
dokonywane: 1) w formie faksu (winfaksu) przesłanego do podstawowego biura poselskiego; 2) w formie wiadomości przesłanej za pośrednictwem poczty elektronicznej na oficjalny adres sejmowy posła; 3) w formie wiadomości tekstowej przesłanej na podany przez posła numer telefonu komórkowego; 4) telefonicznie; 5) w formie przesyłki pocztowej przesłanej na wskazany przez posła adres do korespondencji; 6) przez odczytanie komunikatu na posiedzeniu Sejmu; 7) przez wyłożenie zawiadomienia do skrytek poselskich w kuluarach sali posiedzeń Sejmu w przeddzień posiedzenia Sejmu lub w trakcie jego trwania.

Ponadto w szczególnie uzasadnionych przypadkach zawiadomienie może być dokonane $\mathrm{w}$ formie osobistego poinformowania posła (ust. 2). Uchwała przesądza również, że podstawową formą doręczania zawiadomienia jest przesłanie go za pośrednictwem poczty elektronicznej na oficjalny adres sejmowy posła (\$2 ust. 1). W szczególnie uzasadnionych przypadkach przewodniczący komisji sejmowej może podjąć decyzję o przyjęciu innej podstawowej formy zawiadamiania posłów o posiedzeniu komisji sejmowej spośród form określonych wyżej w pkt 1 oraz pkt $3-7$.

Treść art. 152 ust. 5 zdanie drugie sformułowana została w sposób niefortunny. Składnia tego zdania (lokalizacja wtrącenia „na zasadach i w trybie określonych przez Prezydium Sejmu”) sugerować może, że obowiązek zachowania zasad określonych przez Prezydium Sejmu dotyczy wyłącznie sytuacji, w której członkowie komisji zawiadamiani są o posiedzeniu komisji co najmniej na trzy dni przed jego terminem, zaś tryb zawiadamiania o posiedzeniu, które zostało zwołane w wyniku decyzji podjętych na posiedzeniu Sejmu, nie musi respektować tych reguł. Wniosek taki byłby jednak błędny i stałby w jaskrawej kolizji $\mathrm{z}$ ratio legis omawianej regulacji. Uchwała Prezydium Sejmu określa zasady i tryb zawiadamiania członków komisji o posiedzeniach zwoływanych zgodnie z regułą podstawową, jak i tych, które zwoływane są w trybie ekstraordynaryjnym.

\section{Podsumowanie}

- Artykuł 152 ust. 5 regulaminu Sejmu wyraża trzy zasady. Pierwsze zdanie ustanawia (1) obowiązek zawiadomienia o terminie i porządku dziennym posiedzenia członków komisji oraz wskazanych podmiotów. Drugie zdanie określa (2) termin zawiadomienia członków komisji (co najmniej na trzy dni przed posiedzeniem komisji, chyba że posiedzenie zwołane zostało w wyniku decyzji podjętych na posiedzeniu Sejmu), oraz (3) ustanawia podstawę prawną dla sformułowania przez Prezydium Sejmu zasad i trybu wykonywania tego obowiązku.

- Zawiadomienie członków komisji o posiedzeniu komisji (terminie i porządku dziennym) powinno nastąpić co najmniej na trzy dni przed posiedzeniem komisji, chyba że posiedzenie zwołane zostało w wyniku decyzji podjętych 
na posiedzeniu Sejmu. Oznacza to, że, co do zasady, informacja o terminie i porządku dziennym posiedzenia komisji powinna dotrzeć do wszystkich członków komisji nie później niż do końca dnia, który swoją datą poprzedza o trzy dni termin posiedzenia komisji.

- Obowiązek ten stanowi istotną gwarancję swobody sprawowania mandatu poselskiego. Omawiana zasada pozwala każdemu członkowi komisji zaplanować kalendarz działań z uwzględnieniem wszystkich innych indywidualnych obowiązków.

- Treść art. 152 ust. 5 regulaminu Sejmu wiąże się z kilkoma wątpliwościami interpretacyjnymi, które de lege lata mogłyby zostać usunięte poprzez nowelizację tego przepisu.

\section{Bibliografia}

Radziewicz P., Uwagi do art. 152 [w:] Komentarz do Regulaminu Sejmu Rzeczypospolitej Polskiej, red. A. Szmyt, Warszawa 2018. 
Ewelina Gierach

\title{
Stosowanie przepisów Kodeksu postępowania administracyjnego przez Sejm i jego organy ${ }^{1}$
}

\begin{abstract}
Application of provisions of the Code of Administrative Procedure by the Sejm and its organs (WAKiU-1529/18): The Sejm, as a body of legislative power, is not a public administration body within the meaning of the Code of Administrative Procedure. Thus there is no obligation to apply the provisions of this act. The Sejm committees, which are internal organs of the chamber, also have no obligation to do so. They cannot be a party to proceedings before an administrative court. The Code of Administrative Procedure provides for the possibility of referring a complaint to the Sejm or its internal body (committee), but there are no legal provisions regulating the procedure of examining complaints against state authorities other than executive organs.
\end{abstract}
Keywords: Code of Administrative Procedure, committee of the Sejm, Sejm
Słowa kluczowe: Kodeks postępowania administracyjnego, komisja sejmowa, Sejm

Doktor nauk prawnych, adiunkt Uniwersytetu Kardynała Stefana Wyszyńskiego w Warszawie, ekspert ds. legislacji BAS; ewelina.gierach@sejm.gov.pl.

\section{Przedmiot opinii}

Przedmiotem opinii jest odpowiedź na następujące pytania:

- „czy Sejm i jego organy mają obowiązek stosować przepisy Kodeksu postępowania administracyjnego, a jeśli tak to $\mathrm{w}$ jakim zakresie?

- czy skargi kierowane do komisji sejmowych przez obywateli powinny być rozpatrywane przez komisje na podstawie przepisów Kodeksu postępowania administracyjnego?

- czy komisja sejmowa może być stroną w postępowaniu przed sądem administracyjnym?".

1 Opinia prawna dotycząca stosowania przepisów Kodeksu postępowania administracyjnego przez Sejm i jego organy sporządzona 27 czerwca 2018 r. na zlecenie przewodniczącego Komisji Regulaminowej, Spraw Poselskich i Immunitetowych; BAS-WAKiU $1529 / 18$. 


\section{Analiza szczegółowa}

1. Zagadnienie obowiązku stosowania przez Sejm in pleno oraz jego organy wewnętrzne przepisów ustawy z 14 czerwca 1960 r. - Kodeks postępowania administracyjnego (t.j. Dz.U. 2017, poz. 1257, ze zm.; dalej: k.p.a.) jest zagadnieniem bardzo złożonym. Odpowiedź na to pytanie determinują przepisy tego Kodeksu.

Zakres stosowania przepisów Kodeksu postępowania administracyjnego określają art. 1-3 tego aktu. Zgodnie z art. 1: Kodeks postępowania administracyjnego normuje:

1) postępowanie przed organami administracji publicznej w należacych do właściwości tych organów sprawach indywidualnych rozstrzyganych $w$ drodze decyzji administracyjnych albo załatwianych milczaco; 2) postępowanie przed innymi organami państwowymi oraz przed innymi podmiotami, gdy sa one powołane z mocy prawa lub na podstawie porozumień do załatwiania spraw określonych w pkt 1; 3) postepowanie w sprawach rozstrzygania sporów o właściwość między organami jednostek samorzadu tery torialnego i organami administracji rządowej oraz między organami i podmiotami, o których mowa w pkt 2; 4) postępowanie w sprawach wydawania zaświadczeń; 5) nakładanie lub wymierzanie administracyjnych kar pieniężnych lub udzielanie ulg wich wykonaniu; 6) tryb europejskiej wspótpracy administracyjnej.

Ponadto akt ten normuje postępowanie w sprawie skarg i wniosków (dział VIII) przed organami państwowymi, organami jednostek samorządu terytorialnego oraz przed organami organizacji społecznych (art. 2 k.p.a.), zaś na podstawie art. 3 jego przepisów nie stosuje się do postępowania w sprawach karnych skarbowych oraz spraw uregulowanych w ustawie z 29 sierpnia 1997 r. - Ordynacja podatkowa, z wyjątkiem przepisów działów IV, V i VIII, a także spraw należących do właściwości polskich przedstawicielstw dyplomatycznych i urzędów konsularnych, o ile przepisy szczególne nie stanowią inaczej. Przepisów Kodeksu postępowania administracyjnego nie stosuje się także do postępowania w sprawach wynikających z nadrzędności i podległości organizacyjnej w stosunkach między organami państwowymi i innymi państwowymi jednostkami organizacyjnymi, podległości służbowej pracowników organów i jednostek organizacyjnych, o ile przepisy szczególne nie stanowią inaczej.

Jednocześnie art. $5 \$ 2$ pkt 3 k.p.a. formułuje ustawową definicję pojęcia organów administracji publicznej, przesądzając, iż rozumie się przez nie: ministrów, centralne organy administracji rządowej, wojewodów, działające w ich lub we własnym imieniu inne terenowe organy administracji rządowej (zespolonej i niezespolonej), organy jednostek samorządu terytorialnego oraz inne organy państwowe i inne podmioty, jeżeli są one powołane z mocy prawa lub na podstawie porozumień do załatwiania spraw indywidualnych rozstrzyganych w drodze decyzji administracyjnych albo załatwianych milcząco.

$\mathrm{Na}$ tym tle należy stwierdzić, że Sejm, jako organ władzy ustawodawczej, nie jest organem administracji publicznej w rozumieniu Kodeksu postępowa- 
nia administracyjnego i nie ma obowiązku stosowania jego przepisów. Tym bardziej obowiązku tego nie mają komisje sejmowe, które jako organy wewnętrzne uczestniczą w realizowaniu zarówno ustawodawczej, jak i kontrolnej funkcji Sejmu. Co więcej, nie sposób pominąć faktu, że tryb działalności Sejmu oraz jego organów wewnętrznych jest determinowany na poziomie konstytucyjnym. Zgodnie z art. 112 Konstytucji: [o] rganizację wewnętrzna i porządek prac Sejmu oraz tryb powoływania $i$ działalności jego organów, jak też sposób wykonywania konstytucyjnych i ustawowych obowiązków organów państwowych wobec Sejmu określa regulamin uchwalony przez Sejm. Zatem zarówno porządek prac Sejmu, jak też tryb działalności organów wewnętrznych izby jest objęty zakresem konstytucyjnej zasady autonomii i należy do materii regulaminowej.

Uznając brak obowiązku stosowania przez Sejm przepisów Kodeksu postępowania administracyjnego, należy jednak zauważyć, że akt ten w art. 2 jako adresatów skarg i wniosków wskazuje nie organy administracji publicznej, a organy państwowe. W literaturze przedmiotu podkreśla się, iż pojęcie organu państwowego jest szerokie, oznacza bowiem konstytucyjne i ustawowe organy państwa i obejmuje organy władzy ustawodawczej, organy władzy wykonawczej i organy wymiaru sprawiedliwości². Uznając możliwość kierowania skarg w rozumieniu przepisów Kodeksu postępowania administracyjnego do Sejmu, należy jednak podkreślić, że Kodeks ten nie reguluje kwestii rozpatrywania skarg na organy państwa inne niż organy władzy wykonawczej. Brak jest również jakichkolwiek regulacji ustawowych regulujących tę procedurę. Problem ten był już przed laty zauważany i podkreślany w opinii Biura Analiz Sejmowych, w której wyrażono konkluzję o braku możliwości rozpatrzenia skargi skierowanej do Sejmu w trybie przewidzianym przepisami działu VIII Kodeksu postępowania administracyjnego. Autorka tej opinii zaznaczyła, że listy (w tym również skargi) kierowane do Sejmu i jego organów powinny stanowić materiał do debaty sejmowej bądź debaty na forum komisji ${ }^{3}$. W mojej ocenie pogląd ten pozostaje aktualny.

2. Analizując zagadnienie dopuszczalności składania przez obywateli skarg do komisji sejmowych, w pierwszym rzędzie należy zauważyć, że prawo do składania skarg ma rangę konstytucyjną. Przewidziane jest ono bowiem w art. 63 Konstytucji, który stanowi, iż: [k]ażdy ma prawo składać petycje, wnioski i skargi $w$ interesie publicznym, własnym lub innej osoby za jej zgoda do organów wła$d z y$ publicznej oraz do organizacji $i$ instytucji społecznych $w$ związu $z$ wykonywanymi przez nie zadaniami zleconymi z zakresu administracji publicznej. Tryb

2 Zob. A. Wróbel, Komentarz do art. 2 [w:] A. Wróbel, M. Jaśkowska, Kodeks postępowania administracyjnego. Komentarz, Warszawa 2018.

Zob. I. Galińska-Rączy, Opinia prawna z dnia 24 listopada 1999 r. na temat możliwości stosowania przepisów Kodeksu postępowania administracyjnego regulujacych postępowanie $w$ sprawie skarg i wniosków do skarg na działalność Rzecznika Praw Obywatelskich kierowanych do organów Sejmu, 1732/99, niepubl. 
rozpatrywania petycji, wniosków i skarg określa ustawa. Ustawą, o której mowa w tym przepisie, jest Kodeks postępowania administracyjnego, a mówiąc ściślej jego dział VIII „Skargi i wnioski”. Na tym tle rozważenia wymaga odpowiedź na pytanie o to, czy kierowane do organów wewnętrznych Sejmu skargi są w istocie skargami w rozumieniu przepisów Kodeksu postępowania administracyjnego i czy w związku z powyższym powinny być one rozpatrywane na podstawie przepisów tego Kodeksu.

Zgodnie z art. $221 \$ 1$ k.p.a. prawo składania skarg i wniosków do organów państwowych, organów jednostek samorządu terytorialnego, organów samorządowych jednostek organizacyjnych oraz do organizacji i instytucji społecznych realizowane jest na zasadach określonych przepisami działu VIII Kodeksu. Skargi i wnioski mogą być także składane do organizacji i instytucji społecznych w związku z wykonywanymi przez nie zadaniami zleconymi z zakresu administracji publicznej ( $\$ 2$ tego przepisu). Należy zauważyć, iż zarówno w art. 63 Konstytucji, jak i w art. 221 k.p.a. został wskazany krąg podmiotów, do których mogą być składane skargi. Konstytucja określa te podmioty jako „organy władzy publicznej”, zaś Kodeks wymienia „organy państwowe, organy jednostek samorządu terytorialnego, organy samorządowych jednostek organizacyjnych" (ze względu na zakres niniejszej opinii nie odnoszę się do kwestii organizacji i instytucji społecznych jako adresatów skarg i wniosków). Jakkolwiek Sejm jest bez wątpienia organem władzy publicznej i organem państwowym, w świetle przytoczonych przepisów nie sposób uznać za objęte zakresem regulacji kodeksowych skarg kierowanych do organu wewnętrznego parlamentu. Skargi tego rodzaju nie zostały przewidziane ani na poziomie konstytucyjnym, ani na poziomie regulaminowym.

Na tle powyższych rozważań za uzasadnione wydaje się przyjęcie, że ewentualne skargi kierowane do komisji sejmowych należy traktować jako wystąpienia o charakterze pozaprawnym, nieobjęte zakresem regulacji Kodeksu postępowania administracyjnego. Skargi te stanowią $\mathrm{w}$ istocie pewne nieformalne wyrazy dezaprobaty dla działalności komisji bądź jej bezczynności w określonym zakresie. W pewnym sensie formą realizacji prawa do składania skarg i wniosków w odniesieniu do komisji sejmowych jest możliwość nadsyłania do nich korespondencji, również $\mathrm{w}$ formie elektronicznej przez formularze dostępne w Systemie Informacyjnym Sejmu. Jakkolwiek rozpatrywanie tego rodzaju korespondencji leży w gestii komisji sejmowej, z uwagi na fakt, iż kierowane do organów wewnętrznych izby skargi nie stanowią skarg w rozumieniu przepisów Kodeksu postępowania administracyjnego, na komisji nie spoczywa prawny obowiązek rozpatrzenia ich w trybie przewidzianym przepisami tego aktu.

3. Odnosząc się do ostatniego z postawionych na wstępie pytań, należy zauważyć, że działalność komisji sejmowych nie podlega kontroli sądów administracyjnych. Granice właściwości sądów administracyjnych oraz istota wymiaru sprawiedliwości sprawowanego przez te sądy zostały bowiem określone wprost 
w art. 184 Konstytucji RP. Z przepisu tego wynika, że sądy administracyjne sprawują, w zakresie określonym w ustawie, kontrolę działalności administracji publicznej. Kontrola ta obejmuje również orzekanie o zgodności z ustawami uchwał organów samorządu terytorialnego oraz aktów normatywnych organów administracji rządowej. Zakres właściwości sądów administracyjnych precyzują przepisy ustawy z 30 sierpnia 2002 r. - Prawo o postępowaniu przed sądami administracyjnymi (t.j. Dz.U. 2017, poz. 1369, ze zm.). Zgodnie zaś z art. $3 \$ 1$ i 2 tego aktu sądy administracyjne sprawują kontrolę działalności administracji publicznej, a kontrola ta obejmuje: orzekanie $w$ sprawach skarg na:

1) decyzje administracyjne;

2) postanowienia wydane $w$ postępowaniu administracyjnym, na które służy zażalenie albo kończace postępowanie, a także na postanowienia rozstrzygające sprawę co do istoty;

3) postanowienia wydane w postępowaniu egzekucyjnym i zabezpieczajacym, na które służy zażalenie, z wyłączeniem postanowień wierzyciela o niedopuszczalności zgłoszonego zarzutu oraz postanowień, przedmiotem których jest stanowisko wierzyciela $w$ sprawie zgłoszonego zarzutu;

4) inne niż określone $w$ pkt 1-3 akty lub czynności z zakresu administracji publicznej dotyczace uprawnień lub obowiązków wynikajacych z przepisów prawa, $z$ wyłaczeniem aktów lub czynności podjętych $w$ ramach postępowania administracyjnego określonego w ustawie z dnia 14 czerwca 1960 r. - Kodeks postępowania administracyjnego (...), postępowań określonych $w$ działach IV, V $i$ VI ustawy z dnia 29 sierpnia 1997 r. - Ordynacja podatkowa (...), postępowań, o których mowa $w$ dziale $V w$ rozdziale 1 ustawy z dnia 16 listopada 2016 r. o Krajowej Administracji Skarbowej (Dz. U. poz. 1947, z późn.zm.), oraz postępowań, do których maja zastosowanie przepisy powołanych ustaw;

4a) pisemne interpretacje przepisów prawa podatkowego wydawane $w$ indywidualnych sprawach, opinie zabezpieczające i odmowy wydania opinii zabezpieczajacych;

5) akty prawa miejscowego organów jednostek samorzadu terytorialnego i terenowych organów administracji rządowej;

6) akty organów jednostek samorządu terytorialnego i ich związków, inne niż określone w pkt 5, podejmowane w sprawach z zakresu administracji publicznej;

7) akty nadzoru nad działalnością organów jednostek samorządu terytorialnego;

8) bezczynność lub przewlekłe prowadzenie postępowania w przypadkach określonych w pkt 1-4 lub przewlekłe prowadzenie postępowania w przypadku określonym $w$ pkt $4 a$;

9) bezczynność lub przewlekłe prowadzenie postępowania w sprawach dotyczacych innych niż określone $w$ pkt 1-3 aktów lub czynności z zakresu administracji publicznej dotyczacych uprawnień lub obowiązków wynikających z przepisów prawa podjettych $w$ ramach postępowania administracyjnego określonego $w$ ustawie 
$z$ dnia 14 czerwca 1960 r. - Kodeks postępowania administracyjnego oraz postępowań określonych w działach IV, Vi VI ustawy z dnia 29 sierpnia 1997 r. - Ordynacja podatkowa oraz postępowań, do których maja zastosowanie przepisy powołanych ustaw.

$\mathrm{Na}$ mocy art. 4 tego samego aktu sądy administracyjne rozstrzygają spory o właściwość między organami jednostek samorządu terytorialnego i między samorządowymi kolegiami odwoławczymi, o ile odrębna ustawa nie stanowi inaczej, oraz spory kompetencyjne między organami tych jednostek a organami administracji rządowej. Zgodnie zaś z art. 5 cytowanej ustawy nie są one właściwe w sprawach:

1) wynikajacych z nadrzędności i podległości organizacyjnej w stosunkach między organami administracji publicznej;

2) wynikajacych z podległości służbowej między przełożonymi i podwładnymi;

3) odmowy mianowania na stanowiska lub powołania do pełnienia funkcji $w$ organach administracji publicznej, chyba że obowiazek mianowania lub powołania wynika z przepisów prawa;

4) wiz wydawanych przez konsulów, $z$ wyjątkiem wiz wydanych cudzoziemcowi będacemu członkiem rodziny obywatela państwa członkowskiego Unii Europejskiej, państwa członkowskiego Europejskiego Porozumienia o Wolnym Handlu (EFTA) - strony umowy o Europejskim Obszarze Gospodarczym lub Konfederacji Szwajcarskiej, w rozumieniu art. 2 pkt 4 ustawy z dnia 14 lipca 2006 r. o wjeździe na terytorium Rzeczypospolitej Polskiej, pobycie oraz wyjeździe z tego terytorium obywateli państw członkowskich Unii Europejskiej i członków ich rodzin (Dz. U. z 2017 r. poz. 900);

5) zezwoleń na przekraczanie granicy $w$ ramach małego ruchu granicznego wydawanych przez konsulów.

Z przywołanych wyżej przepisów wynika, że zakres kognicji sądów administracyjnych został ograniczony do kontroli administracji publicznej. Komisji sejmowej nie można zaś uznać za organ administracji publicznej. Komisje sejmowe są bowiem organami wewnętrznymi izby parlamentu (art. 110 ust. 3 Konstytucji oraz art. 9 pkt 4 regulaminu Sejmu), które są powołane do rozpatrywania i przygotowywania spraw stanowiących przedmiot prac Sejmu oraz wyrażania opinii w sprawach przekazanych pod ich obrady przez Sejm, Marszałka Sejmu lub Prezydium Sejmu (art. 17 ust. 1 regulaminu Sejmu). Komisje uczestniczą zatem w wykonywaniu funkcji ustawodawczej, są również organami kontroli sejmowej (art. 17 ust. 2 regulaminu Sejmu). Realizują one funkcję ustawodawczą oraz kontrolną, z pewnością zaś ich działanie nie jest elementem postępowania administracyjnego ${ }^{4}$.

4 Zob. wyrok WSA w Warszawie z 30 listopada 2006 r., sygn. akt IV SAB/Wa 141/06. 


\section{Podsumowanie}

- Sejm, jako organ władzy ustawodawczej, nie jest organem administracji publicznej w rozumieniu Kodeksu postępowania administracyjnego i nie ma obowiązku stosowania przepisów tego aktu. Obowiązku tego nie mają także komisje sejmowe, będące organami wewnętrznymi izby.

- Jakkolwiek przepisy Kodeksu postępowania administracyjnego przewidują możliwość skierowania skargi do Sejmu, jako organu państwowego, należy stwierdzić, że brak jest regulacji prawnej normującej kwestię trybu rozpatrywania skarg na organy państwa inne niż organy władzy wykonawczej. W konsekwencji skargi kierowane do Sejmu powinny stanowić swego rodzaju materiał do debaty sejmowej i inspirować.

- Z uwagi na fakt, że kierowane do organów wewnętrznych Sejmu skargi nie stanowią skarg w rozumieniu przepisów działu VIII Kodeksu postępowania administracyjnego, na komisji nie spoczywa prawny obowiązek rozpatrzenia ich w trybie przewidzianym przepisami tego aktu. Skargi te stanowią $\mathrm{w}$ istocie pewne nieformalne wyrazy dezaprobaty dla działalności komisji bądź jej bezczynności w określonym zakresie.

- Komisji sejmowej nie można uznać za organ administracji publicznej, w konsekwencji nie może być ona stroną w postępowaniu przed sądem administracyjnym.

\section{Bibliografia}

Galińska-Rączy I., Opinia prawna z dnia 24 listopada 1999 r. na temat możliwości stosowania przepisów Kodeksu postępowania administracyjnego regulujących postępowanie $w$ sprawie skarg i wniosków do skarg na działalność Rzecznika Praw Obywatelskich kierowanych do organów Sejmu, 1732/99, niepubl.

Wróbel A., Komentarz do art. 2 [w:] A. Wróbel, M. Jaśkowska, Kodeks postępowania administracyjnego. Komentarz, Warszawa 2018. 


\section{Wykładnia art. 23 ust. 2 regulaminu Sejmu - odwołanie od uchwały Prezydium Sejmu o obniżeniu uposażenia lub diety parlamentarnej ${ }^{1}$}

Interpretation of Article 23 para. 2 of the Standing Orders of the Sejm - an appeal against a resolution of the Presidium of the Sejm on decreasing the salary of a Deputy or parliamentary per diem allowance (WAUiP-2305/17): Analysis of the matter of decisions that may be taken by the Presidium of the Sejm, considering an application for reconsideration of the case. In the author's opinion, the scope of possible decisions of the Presidium of the Sejm, made on the basis of the analyzed provision, includes: sustaining the original resolution, repealing it, as well as changing the amount of deprivation of Deputy's benefits made in the original resolution (in favour of the appealing Deputy).

Keywords: Deputy, Presidium of the Sejm, Standing Orders of the Sejm

Słowa kluczowe: poseł, Prezydium Sejmu, regulamin Sejmu

Ekspert ds. legislacji BAS; wojciech.sypniewski@sejm.gov.pl.

\section{Przedmiot opinii}

Przedmiotem opinii jest wykładnia art. 23 ust. 2 regulaminu Sejmu. Wątpliwość, dotyczy tego, czy Prezydium Sejmu, rozpatrując wniosek o ponowne rozpatrzenie sprawy, przedłożony w trybie art. 23 ust. 2 regulaminu Sejmu, może jedynie uchylić lub utrzymać w mocy pierwotną uchwałę, czy też może obniżyć dietę (uposażenie) w wymiarze innym niż ustalony w pierwszej uchwale?

Opinia prawna na temat wykładni art. 23 ust. 2 regulaminu Sejmu (odwołanie od uchwały Prezydium Sejmu o obniżeniu uposażenia lub diety parlamentarnej) sporządzona 17 listopada 2017 r. na zlecenie zastępcy Szefa Kancelarii Sejmu; BAS-WAUiP 2305/17. 


\section{Tryb rozpatrywania spraw posłów uniemożliwiających pracę Sejmu lub jego organów}

1. Odpowiedzialność regulaminowa posłów na podstawie art. 23 ust. 1 dotyczy „uniemożliwiania pracy Sejmu lub jego organów”. Pojęcie to obejmuje klasę czynów (działań lub zaniechań), które prowadzą do dezorganizacji pracy Sejmu lub jego organów. Z pojęciem „uniemożliwiania pracy” mogą wiązać się różne sytuacje faktyczne, które trudno byłoby sprecyzować w przepisach regulaminu Sejmu².

Prezydium Sejmu wykonując kompetencję, o której mowa w art. 23, podejmuje swoje działania z urzędu. Inspiracją dla działań Prezydium Sejmu mogą być informacje przekazane przez Marszałka Sejmu albo przedstawiciela organu, którego prace zostały zakłócone, ale także informacje pochodzące z innych źródeł. Inicjatorem działań Prezydium Sejmu w tych sprawach najczęściej będzie Marszałek Sejmu, ponieważ to na nim ciąży obowiązek sprawowania pieczy nad spokojem i porządkiem na całym obszarze należącym do Sejmu (art. 10 ust. 1 pkt 13 regulaminu Sejmu), a także do niego należy ustalanie porządku dziennego i terminów posiedzenia Prezydium Sejmu (art. 13 ust. 1 regulaminu Sejmu). W praktyce od Marszałka Sejmu zależeć będzie zatem, czy Prezydium Sejmu podejmie działania zmierzające do egzekwowania tej formy odpowiedzialności regulaminowej ${ }^{3}$.

Prezydium Sejmu, rozpatrując sprawy z art. 23 regulaminu Sejmu, korzysta z typowych instrumentów służących wyjaśnieniu badanej sprawy (analiza dokumentów, wysłuchanie wyjaśnień zainteresowanego lub innych osób mających wiedzę na temat sprawy). Prezydium Sejmu nie przysługują jednak w tym zakresie żadne środki o charakterze władczym. Przepisy regulaminu Sejmu nie gwarantują zainteresowanemu posłowi prawa udziału w posiedzeniu Prezydium Sejmu, na którym rozpatrywana jest jego sprawa.

Uchwała Prezydium Sejmu stanowi wynik oceny okoliczności czynu, który spowodował uniemożliwienie pracy Sejmu lub jego organów, i może przewidywać obniżenie uposażenia lub diety parlamentarnej posła, w wysokości nieprzekraczającej 1/2 wysokości uposażenia poselskiego lub pełnej diety parlamentarnej miesięcznie na okres nie dłuższy niż 3 miesiące. Należy podkreślić, że nałożenie przez Prezydium Sejmu sankcji za naruszenie porządku pracy ma charakter fakultatywny. Mimo stwierdzenia deliktu Prezydium Sejmu zachowuje swobodę w zakresie wymierzenia kary (np. może odstąpić od wymierzenia kary finansowej z uwagi na okoliczności zdarzenia). Uchwała o obniżeniu uposażenia lub diety powinna określać w granicach, wyznaczonych przez art. 23 ust. 1 regulaminu Sejmu, wysokość

M. Kudej, Zmiany w regulaminie Sejmu uchwalone na początku IV kadencji, „Przegląd Sejmowy" 2002, nr 5, s. 67.

3 Zob. J. Mordwiłko, Wykładnia art. 25 regulaminu Sejmu, stanowiacego o stosowaniu sankcji za wykluczenie posła z posiedzenia Sejmu [w:] Regulamin Sejmu w opiniach Biura Analiz Sejmowych, t. I, red. W. Odrowąż-Sypniewski, Warszawa 2010, s. 163. 
obniżenia oraz okres, przez który będzie ono obowiązywać. Określając wymiar kary, Prezydium Sejmu powinno wziąć pod uwagę wszystkie okoliczności zdarzenia oraz zakres, w jakim czyn posła doprowadził do dezorganizacji prac izby.

Obniżeniu może ulec każde z wymienionych w art. 23 ust. 1 regulaminu Sejmu świadczeń albo oba świadczenia naraz ${ }^{4}$. Konkretny wymiar kary nie musi zakładać takiego samego potrącenia we wszystkich miesiącach objętych okresem wykonania kary (potrącenie $\mathrm{w}$ danym miesiącu nie może jednak przekraczać maksymalnej wysokości).

Uchwała o obniżeniu uposażenia powinna mieć formę pisemną, ponieważ regulamin formułuje wymóg doręczenia tej uchwały posłowi, którego ona dotyczy. Mając na uwadze, że zainteresowanemu przysługuje prawo złożenia wniosku o ponowne rozpatrzenie sprawy przez Prezydium Sejmu (art. 23 ust. 2 regulaminu Sejmu), należy przyjąć, że uchwale powinno towarzyszyć uzasadnienie wyjaśniające motywy rozstrzygnięcia.

2. Sygnalizowana na początku opinii wątpliwość interpretacyjna dotyczy art. 23 ust. 2 regulaminu Sejmu, który przewiduje, że: od uchwaty o obniżeniu uposażenia lub diety parlamentarnej (...) posłowi przystuguje, $w$ terminie 7 dni od dnia doręczenia uchwaty, wniosek o ponowne rozpatrzenie sprawy przez Prezydium Sejmu. Prezydium Sejmu ponownie rozpatruje sprawę po zasięgnięciu opinii Konwentu Seniorów. Z treści tego przepisu wynika, że Prezydium Sejmu może ponownie rozpatrzyć sprawę wyłącznie na wniosek posła, którego dotyczy uchwała wymierzająca karę finansową. Regulamin nie określa formy wniosku, jednak zasadne wydaje się zachowanie formy pisemnej. Termin na wniesienie wniosku należy uznać za spełniony, jeżeli przed upływem 7 dni od dnia doręczenia uchwały do Marszałka Sejmu (reprezentującego w praktyce Prezydium Sejmu) dotrze oświadczenie zainteresowanego (wniosek o ponowne rozpatrzenie sprawy).

Dylemat dotyczący zakresu kompetencji przysługującej Prezydium Sejmu $\mathrm{w}$ ramach rozpatrywania wniosku o ponowne rozpatrzenie sprawy rozstrzygać należy z uwzględnieniem zasad wykładni językowej i systemowej. Przedmiotem wniosku kierowanego do Prezydium Sejmu jest postulat „ponownego rozpatrzenia sprawy" przez Prezydium Sejmu. W tej fazie postępowania rola Prezydium Sejmu nie ogranicza się zatem do oceny prawidłowości pierwotnej uchwały, lecz obejmuje ponową analizę wszystkich okoliczności faktycznych towarzyszących zdarzeniu, dających się ustalić motywów działania sprawcy oraz szkodliwości „czynu”. Ponowne rozpatrzenie sprawy zakłada zatem ocenę zasadności nałożenia sankcji finansowych na posła, który uniemożliwił prace Sejmu lub jego organów, której wynikiem może być utrzymanie w mocy pierwotnej uchwały

4 Zob. wypowiedź Marszałka M. Borowskiego reprezentującego Prezydium Sejmu $\mathrm{w}$ trakcie pierwszego czytania projektu nowelizacji regulaminu Sejmu ustanawiającej omawiany przepis; posiedzenie Komisji Regulaminowej i Spraw Poselskich w dniu 19 kwietnia 2002 r., biuletyn Komisji Regulaminowej i Spraw Poselskich 501/IV kad. 
jak również jej uchylenie (w tym także zmiana wysokości obniżenia świadczeń finansowych lub zmiana okresu, w który obniżenie ma obowiązywać).

Wykładnię językową potwierdzają argumenty natury systemowej. W doktrynie poszczególnych gałęzi prawa procesowego powszechnie przyjęty jest podział środków zaskarżenia na środki odwoławcze - mające charakter dewolutywny i inne środki zaskarżenia - niemające takiego charakteru. Jak wskazał Trybunał Konstytucyjny, wniosek o ponowne rozpatrzenie sprawy, o którym mowa w art. $127 \$ 3$ Kodeksu postępowania administracyjnego (dalej: k.p.a.), jest środkiem prawnym o charakterze niedewolutywnym. Wniesienie tego środka nie powoduje skutku w postaci przesunięcia kompetencji do rozpoznania lub rozstrzygnięcia sprawy na organ wyższego stopnia, lecz powierza ją ponownie temu samemu organowi. Jest natomiast środkiem suspensywnym - do upływu terminu do złożenia wniosku o ponowne rozpoznanie sprawy, a w razie jego wniesienia w terminie do czasu wydania ponownego rozstrzygnięcia, wstrzymane jest wykonanie pierwszego rozstrzygnięcia ${ }^{5}$. Organ rozpatrujący wniosek o ponowne rozpatrzenie sprawy, o którym mowa w art. $127 \$ 3$ k.p.a., jest zobowiązany do powtórnego rozpoznania i rozstrzygnięcia sprawy w całości ${ }^{6}$.

Podobieństwo środka odwoławczego, o którym mowa w art. 23 ust. 2 regulaminu Sejmu, do instytucji z art. $127 \$ 3$ k.p.a. (analogia iuris) uzasadnia ocenę, że regulaminowy wniosek o ponowne rozpatrzenie sprawy jest środkiem o charakterze niedewolutywnym (sprawa ponownie rozpatrywana jest przez ten sam organ - Prezydium Sejmu) oraz suspensywnym (wniesienie odwołania wstrzymuje wykonanie pierwszej uchwały Prezydium Sejmu - art. 23 ust. 3 regulaminu Sej$\mathrm{mu}$ ), a jego rozpatrzenie zakładać powinno powtórne rozpoznanie i rozstrzygnięcie sprawy. W konsekwencji należy uznać, że Prezydium Sejmu, rozpatrując odwołanie, może nie tylko utrzymać tę uchwałę w mocy lub ją uchylić, ale również może zmienić wysokość sankcji finansowej.

Wzgląd na zupełność prezentowanej analizy wymaga postawienia pytania, czy zmiana wysokości sankcji w trybie art. 23 ust. 2 regulaminu Sejmu może polegać wyłącznie na jej uchyleniu lub obniżeniu (zmiana wysokości obniżenia świadczeń lub skrócenie okresu, w którym obniżenie obowiązuje), czy też mogłaby polegać na „podwyższeniu” sankcji wymierzonej w pierwotnej uchwale?

W przepisach regulaminu Sejmu, w szczególności w art. 23, nie został wyrażony zakaz reformationis in peius, czyli zakaz zmiany rozstrzygnięcia na niekorzyść posła odwołującego się od pierwotnej uchwały Prezydium Sejmu. Zakaz reformationis in peius uznawany jest w piśmiennictwie za jedną $\mathrm{z}$ istotnych gwarancji procesowych, służącą ochronie praw jednostki. Jego istotą jest umożliwienie stronie niezadowolonej z uzyskanego rozstrzygnięcia w swojej sprawie wniesienia odwo-

Wyrok Trybunału Konstytucyjnego z 15 grudnia 2008 r., sygn. akt P 57/07.

6 P. Przybysz, Komentarz do art. 127 [w:] Kodeks postępowania administracyjnego. Komentarz, 2017, LEX. 
łania bez obaw, że decyzja organu odwoławczego spowoduje bardziej negatywne skutki niż pierwotna. W przypadku obowiązywania tego zakazu ryzyko skarżącego ogranicza się do pozostawienia w mocy rozstrzygnięcia pierwszej instancji. Zakaz ten nie obowiązuje w sposób bezwzględny. W sytuacji kontradyktoryjności sporu (sprzeczność interesów przeciwników procesowych) możliwe jest, że rozstrzygnięcie odwoławcze pogorszy sytuację jednej z odwołujących się stron ${ }^{7}$. Zakaz reformationis in peius obowiązuje w postępowaniu karnym (art. $434 \$ 1$ zdanie pierwsze Kodeksu postępowania karnego), cywilnym (art. 384 Kodeksu postępowania cywilnego), administracyjnym (art. 139 k.p.a.) i administracyjnosądowym (art. $134 \$ 2$ ustawy - Prawo o postępowaniu przed sądami administracyjnymi).

Lakoniczność procedury określającej tryb rozpatrywania odwołania, o którym mowa w art. 23 ust. 2 regulamin Sejmu, umożliwia stosowanie w niej zasad przewidzianych w innych gałęziach prawa (w szczególności w procedurach prawa represyjnego) w zakresie, w jakim służy to ochronie praw jednostki. Wydaje się zatem, że mimo milczenia regulaminu Sejmu należałoby opowiedzieć się za obowiązywaniem zakazu reformationis in peius w omawianym przypadku (analogia legis z art. $434 \$ 1$ zdanie pierwsze Kodeksu postępowania karnego).

\section{Podsumowanie}

Podsumowaniem opinii jest pogląd, że zakres możliwych rozstrzygnięć Prezydium Sejmu na podstawie art. 23 ust. 2 regulaminu Sejmu obejmuje utrzymanie w mocy pierwotnej uchwały, jej uchylenie oraz zmianę wysokości - orzeczonego w pierwotnej uchwale - obniżenia świadczeń poselskich (w kierunku korzystnym dla odwołującego się posła).

\section{Bibliografia}

Federczyk W., Uwagi na temat obowiązywania zakazu reformationis in peius $w$ postępowaniu administracyjnosądowym, „Kwartalnik Prawa Publicznego” 2004, nr 3.

Kudej M., Zmiany w regulaminie Sejmu uchwalone na początku IV kadencji, „Przegląd Sejmowy" 2002, nr 5.

Mordwiłko J., Wykładnia art. 25 regulaminu Sejmu, stanowiącego o stosowaniu sankcji za wykluczenie posła z posiedzenia Sejmu [w:] Regulamin Sejmu w opiniach Biura Analiz Sejmowych, t. I, red. W. Odrowąż-Sypniewski, Warszawa 2010.

Przybysz P., Komentarz do art. 127 [w:] Kodeks postępowania administracyjnego. Komentarz, 2017, LEX.

W. Federczyk, Uwagi na temat obowiązywania zakazu reformationis in peius w postępowaniu administracyjnosądowym, „Kwartalnik Prawa Publicznego” 2004, nr 3. 

\begin{tabular}{l|l}
2 & OPINIE BAS
\end{tabular}

B

ZAGADNIENIA PRAWA MIĘDZYNARODOWEGO I EUROPEJSKIEGO 



\title{
Analiza stopnia implementacji postanowień konwencji dotyczących bezpaństwowców z 1954 r. i 1961 r. w prawie polskim 1
}

Analysis of the degree of implementation of provisions of the conventions on stateless persons of 1954 and 1961 in the Polish legal system (WAPM-991/18): The subject of the opinion is an analysis of the degree of implementation of provisions of the Convention relating to the Status of Stateless Persons of 1954 and the Convention on the Reduction of Statelessness of 1961 in the Polish legal system, in particular: determination of the rules of the Conventions which are present in Polish law; an analysis of possible inconsistencies between the Conventions and Polish law; an indication of legislator's obligations that would arise, if Poland became bound by these Conventions.

\author{
Keywords: foreigner, stateless person, citizenship, ratification, international agre- \\ ement \\ Słowa kluczowe: cudzoziemiec, bezpaństwowiec, obywatelstwo, ratyfikacja, umowa \\ międzynarodowa
}

\section{Przedmiot opinii}

Przedmiotem opinii jest analiza stopnia implementacji postanowień Konwencji o statusie bezpaństwowców z 1954 r. (dalej: konwencja z 1954 r.) i Konwencji o ograniczeniu bezpaństwowości z 1961 r. (dalej: konwencja z 1961 r.) w prawie polskim, a w szczególności:

- ustalenia, jakie normy wymienionych konwencji są obecne prawie polskim,

- czy istnieje sprzeczność między postanowieniami wymienionych konwencji a prawem polskim,

1 Opinia $w$ sprawie analizy stopnia implementacji postanowień konwencji dotyczacych bezpaństwowców z 1954 r. i 1961 r.w prawie polskim sporządzona 13 czerwca 2018 r. na zamówienie posła Klubu Poselskiego Nowoczesna; BAS-WAPM 991/18. 
- jakie obowiązki ustawodawcy zaktualizowałyby się w razie związania się tymi konwencjami.

Pełna odpowiedź na te pytania wymagałaby gruntownej analizy nie tylko prawodawstwa, ale także polskiej praktyki sądowej i administracyjnej. Zagadnienia w zakresie referowania prawa polskiego zostaną przedstawione w podstawowym, głównie ustawowym kształcie. Odpowiedzi na postawione pytania zostaną przy tym przedstawione na tle ogólnej problematyki bezpaństwowości, charakterystyki ogólnej regulacji konwencyjnych, relacji do przyjętych już zobowiązań międzynarodowych Polski dotyczących bezpaństwowców, wreszcie określenia relacji zakresów obu konwencji do prawa polskiego. Trzeba sobie przy tym zdawać sprawę, że gdy mowa o prawie polskim, mamy na uwadze tylko prawo stworzone przez polskiego prawodawcę. Tymczasem częścią prawa polskiego w rozumieniu art. 91 ust. 1 Konstytucji jest także wiążące RP prawo międzynarodowe w szczególności traktatowe, ale również zwyczajowe czy zawarte w innych źródłach prawa międzynarodowego (art. 9 Konstytucji).

Do potrzeb niniejszej opinii na określenie konwencji z 1954 r. i konwencji z 1961 r. używany będzie także zwrot „konwencje o bezpaństwowcach”.

\section{Zjawisko bezpaństwowości - uwagi ogólne}

Zjawisko bezpaństwowości jest znane od dłuższego czasu. Uzyskało ono znaczenie wraz z powszechnym wprowadzeniem przez państwa obywatelstwa w XIX wieku. Przyczyny bezpaństwowości są różne. Do czasu ukształtowania międzynarodowej ochrony praw człowieka uznawano, że przyznawanie obywatelstwa stanowi prerogatywę państw, a nie prawo jednostki. W związku z tym państwa mogły w określonych sytuacjach pozbawiać obywatelstwa (np. wskutek opuszczenia własnego państwa), nie interesując się tym, czy osoba pozbawiona uzyskała inne obywatelstwo. Obywatelstwo można było stracić także przez zawarcie małżeństwa $\mathrm{z}$ cudzoziemcem lub rozwód. Jeśli taki skutek wiązano z małżeństwem lub rozwodem (u źródeł problemu leżało nierównoprawne traktowanie kobiet), a wskutek tych wydarzeń zainteresowany nie nabywał lub nie odzyskiwał obywatelstwa sprzed wydarzenia, stawał się bezpaństwowcem. Obywatelstwa można było także nie nabyć (np. dziecko urodzone z rodziców niemających obywatelstwa w państwie, gdzie obowiązywała zasada prawa krwi). Z prawnego punktu widzenia bezpaństwowość była postrzegana jako konsekwencja tzw. negatywnego zbiegu ustaw o obywatelstwie.

W pierwszej połowie XX wieku wspólnota międzynarodowa podjęła wysiłki, aby wyeliminować przypadki bezpaństwowości. Zdołano w szczególności wynegocjować Konwencję w sprawie pewnych zagadnień dotyczących kolizji ustaw o obywatelstwie oraz protokół dotyczący przypadku bezpaństwowości, 
podpisane w Hadze 12 kwietnia $1930 \mathrm{r}^{2}$. Polska związała się tymi traktatami w 1937 r. (Dz.U. nr 47, poz. 361, ze zm.) 3. Przyjęto w niej zasadę, że decydentem w kwestiach obywatelstwa jest państwo, aczkolwiek działające zgodnie z prawem międzynarodowym dotyczącym obywatelstwa (art. 1 konwencji). Konwencja regulowała zagadnienie negatywnego i pozytywnego zbiegu ustaw o obywatelstwie (podwójne/wielorakie obywatelstwo). Unormowała zagadnienie skutków prawnych opuszczenia własnego państwa, zamążpójścia, urodzenia się dzieci lub naturalizacji rodziców, przysposobienia. Szczególne znaczenie dla zwalczania bezpaństwowości miał protokół dołączony do konwencji, w którym uregulowano przede wszystkim przypadek urodzenia się dziecka na terytorium państwa z matki mającej obywatelstwo tego państwa i ojca niemającego obywatelstwa lub o obywatelstwie nieznanym (art. 1).

Po II wojnie światowej nadal obowiązuje zasada, że państwo decyduje o tym, kto i na jakich warunkach zostaje jego obywatelem albo obywatelstwo to traci ${ }^{4}$. Wojna ukazała nowe oblicza bezpaństwowości i uchodźstwa, czasem związanego także z bezpaństwowością. Ponadto w II połowie XX wieku i początkach XXI wieku obserwujemy fale migracyjne o różnym podłożu, których elementem jest również zjawisko bezpaństwowości.

Według Wysokiego Komisarza ONZ ds. Uchodźców obecnie ok. 10 milionom ludzi odmawia się obywatelstwa. Wskazuje się przy tym cztery zasadnicze przyczyny bezpaństwowości: 1) luki w ustawodawstwie dotyczącym obywatelstwa; 2) negatywny zbieg ustaw o obywatelstwie lub stosowanie ustawodawstwa dyskryminacyjnego; 3) pojawienie się nowych państw i zmiany granic; 4) utrata lub pozbawienie obywatelstwa, np. z uwagi na długoterminowe przebywanie poza granicami państwa lub wskutek zmian w prawie, które wprowadzają kryteria dyskryminacyjne $e^{5}$.

\section{Charakterystyka ogólna konwencji o bezpaństwowcach}

Po II wojnie światowej zawarto dwie umowy międzynarodowe specyficznie poświęcone problematyce bezpaństwowców. Są to Konwencja o statusie bezpań-

2 Konwencja weszła w życie 1 lipca 1937 r. Związało się nią tylko 13 państw, a po II wojnie światowej dodatkowo 11 państw, „League of Nations Treaty Series” vol. 179, s. 89.

3 Ratyfikacja nastąpiła za zgodą wyrażoną w ustawie z 5 marca 1934 r., Dz.U. nr 27, poz. 217. Konwencja i protokół wciąż wiążą RP, aczkolwiek ze zmianami wynikającymi z późniejszych zobowiązań międzynarodowych Polski.

4 B. Nascimbene, Le droit de la nationalité et le droit des organisations d'intégration régionales. Vers de nouveaux statuts de résidents?, RCADI 2013, vol. 367, s. 286-288.

5 Zob. http://www.unhcr.org/stateless-people.html. 
stwowców z 28 września 1954 r. ${ }^{6}$ oraz Konwencja o ograniczeniu bezpaństwowości z 30 sierpnia 1961 r. ${ }^{7}$. Oba traktaty, jako wynegocjowane w ramach ONZ ${ }^{8}$, aspirują do powszechności, chociaż zakres ich akceptacji pozostawia wiele do życzenia (są one wiążące dla mniej niż połowy państw świata) ${ }^{9}$.

Konwencja o statusie bezpaństwowców z 1954 r. składa się z preambuły i 42 artykułów. Zawiera definicję bezpaństwowca, reguluje zobowiązania ogólne i podstawowe zasady traktowania i ochrony bezpaństwowców (art. 1-11) oraz określa ich status prawny, położenie w zakresie zatrudnienia i zarobkowania, opieki społecznej, nadawania obywatelstwa, wydalenia, swobody przemieszczania się, traktowania w sprawach administracyjnych i finansowych (art. 12-32). Konwencja zawiera postanowienia końcowe, w tym klauzule rozwiązywania sporów, wiązania się, terytorialną i federalną, wejścia w życie, przeglądową (art. 33-42). Zgodnie z konwencją jej stroną mogą zostać tylko państwa. Mogą one formułować zastrzeżenia, jakkolwiek z wyłączeniem art. 1 (definicja bezpaństwowca), art. 3 (zakaz dyskryminacji), art. 4 (standard traktowania narodowego w odniesieniu do wolności praktyk religijnych i edukacji religijnej dzieci), art. 16 ust. 1 (prawo swobodnego dostępu do sądu na terytorium państw-stron) oraz art. 33-42 (postanowienia końcowe $)^{10}$. Zastrzeżenia mogą być wycofane w każdej chwili (przez zawiadomienie Sekretarza Generalnego ONZ). Każde państwo, które związało się konwencją, ma obowiązek informacyjny, polegający na przedstawieniu Sekretarzowi Generalnemu ONZ (jako depozytariuszowi umowy - art. 42) praw i regulacji wykonujących konwencję (art. 33). Każde państwo-strona może wypowiedzieć konwencję, przy czym skuteczność tego oświadczenia następuje po

6 UNTS vol. 360, s. 117. Konwencja weszła w życie 6 czerwca 1960 r. Jej stronami jest 90 państw. Spośród państw członkowskich Unii Europejskiej, poza Polską, jej stroną nie są Cypr, Estonia, Malta.

7 UNTS vol. 989, s. 175. Konwencja weszła w życie 13 grudnia 1975 r. Jej stronami jest 71 państw. Spośród państw członkowskich Unii Europejskiej, poza Polską, jej stroną nie są Cypr, Estonia, Francja, Grecja, Hiszpania, Malta, Słowenia.

8 Nad projektami konwencji dotyczących bezpaństwowców pracowała Komisja Prawa Międzynarodowego ONZ. Komisja zaproponowała w 1954 r. projekty konwencji o eliminacji przyszłej bezpaństwowości i o redukcji przyszłej bezpaństwowości, które nie spotkały się z uznaniem państw. W 1961 r. natomiast opracowała Konwencję o ograniczeniu bezpaństwowości, http://legal.un.org/ilc/texts/6_1.shtml.

9 Wysoki Komisarz ONZ ds. Uchodźców opublikował Podręcznik o ochronie bezpaństwowcówwedługKonwencjiz 1954r. dotyczącejstatusubezpaństwowców, Genewa 2014, http://www.unhcr.org/dach/wp-content/uploads/sites/27/2017/04/CH-UNHCR _Handbook-on-Protection-of-Stateless-Persons.pdf. Dostępna też jest wersja w języku polskim, lecz zawiera liczne błędy, http://www.refworld.org/cgi-bin/texis/vtx/rwmain/opendocpdf.pdf? reldoc $=y \&$ docid=54c0b8844.

10 Zastrzeżenia o zróżnicowanym zakresie złożyły do konwencji m.in. Austria, Bułgaria, Czechy, Dania, Finlandia, Francja, Hiszpania, Łotwa, Niderlandy, Niemcy, Portugalia, Rumunia, Słowacja, Szwecja, Węgry, Włochy, Zjednoczone Królestwo. 
upływie roku od daty otrzymania notyfikacji przez Sekretarza Generalnego ONZ (art. 40 ust. 2).

Konwencja o ograniczeniu bezpaństwowości z 1961 r. obejmuje bardzo krótką preambułę oraz 21 artykułów. Reguluje się w niej poszczególne przypadki mające zapobiec bezpaństwowości (art. 1-10), a ponadto zawiera postanowienia dotyczące reguł odnoszących się do działania zobowiązań konwencyjnych (art. 11-13) oraz klauzule rozwiązywania sporów, terytoriów niesamodzielnych, związania się i wejścia w życie, zastrzeżeń, wypowiedzenia, depozytariusza (jest nim Sekretarz Generalny ONZ) i rejestracji (art. 14-21).

Konwencją z 1961 r. również mogą związać się tylko państwa. Mogą one składać zastrzeżenia, z wyjątkiem wszakże art. 11 (obowiązek promowania ustanowienia w ONZ organu odpowiedzialnego za rozpatrywanie roszczeń jednostek uprawnionych na mocy konwencji i udzielenie pomocy w przedłożeniu roszczenia właściwemu organowi), art. 14 (klauzula rozwiązywania sporów) i art. 15 (klauzula terytoriów niesamodzielnych). Oznacza to w praktyce, że niedopuszczalne jest złożenie zastrzeżenia do jakiegokolwiek z postanowień materialnych konwencji (art. 1-10) ${ }^{11}$. Chociaż konwencja milczy w tej sprawie, to zastrzeżenia mogą być wycofane zgodnie z zasadami ogólnymi prawa traktatów (art. 22 konwencji wiedeńskiej o prawie traktatów ${ }^{12}$ ). Istnieje możliwość wypowiedzenia konwencji, przy czym staje się ono skuteczne $\mathrm{z}$ upływem roku od daty otrzymania przez Sekretarza Generalnego ONZ notyfikacji dotyczącej tego wypowiedzenia (art. 19 ust. 1).

Przedstawione konwencje nie dysponują skutkiem bezpośrednim (nie zawierają norm samowykonalnych). Każda z nich, a zwłaszcza jednoznacznie konwencja z 1954 r. (art. 33), wymaga podjęcia działań implementacyjnych. Oznacza to, że w swoim działaniu jest uzależniona od wydania aktów prawa krajowego.

Umowy międzynarodowe mogą odzwierciedlać reguły prawa zwyczajowego albo też je, w przypadku odpowiedniej reprezentatywności i praktyki państw niebędących stronami umowy, generować. Sytuacja ta nie zachodzi co do zasady w przypadku konwencji o bezpaństwowcach. $\mathrm{Z}$ całą pewnością nie są to konwencje o charakterze kodyfikacyjnym. Spory dotyczące uzgadniania ich treści, ograniczony krąg państw-stron oraz niepewna praktyka państw niebędących ich stronami podważają też, poza wyjątkowymi sytuacjami ${ }^{13}$, dopuszczalność kwalifikowania ich jako generujących reguły zwyczajowe.

11 Państwa obchodziły jednak ten zakaz przez formułowanie deklaracji interpretacyjnych. Zastrzeżenia lub deklaracje o zróżnicowanym zakresie złożyły do konwencji m.in. Austria, Belgia, Francja, Irlandia, Litwa, Niemcy i Zjednoczone Królestwo.

12 Konwencja wiedeńska o prawie traktatów sporządzona w Wiedniu dnia 23 maja 1969 r., Dz.U. 1990, nr 74, poz. 439, załącznik.

13 Zob. np. W.Th. Worster, The Presumption of Customary International Law: A Case Study of Child Stateleness, https://papers.ssrn.com/sol3/papers.cfm?abstract_id=3091912. 


\section{Konwencje o bezpaństwowcach a zakres zobowiązań międzynarodowych RP}

Położenie prawne bezpaństwowców jest regulowane w prawie międzynarodowym na dwóch poziomach. Poziom pierwszy, minimalny, wyznacza międzynarodowa ochrona praw człowieka. Innymi słowy, skoro ochrona ta co do zasady jest przeznaczona do ochrony wszystkich osób podlegających jurysdykcji państw ze względu na godność osobową, którą mają, to przysługuje ona również bezpaństwowcom. Wyjątki od tej zasady, dotyczące ochrony obywateli bądź związane jednoznacznie ze statusem obywatelskim (cudzoziemca), są stosunkowo nieliczne. Oznacza to, że w zakresie, w jakim Polska związała się umowami międzynarodowymi dotyczącymi ochrony praw człowieka, zobowiązała się ona także do zagwarantowania odpowiednich praw i wolności bezpaństwowcom. W traktatach dotyczących ochrony praw człowieka bezpaństwowość czy bezpaństwowcy na ogół nie stanowią specyficznego przedmiotu regulacji.

Z tych założeń ideowych wyrasta Uniwersalna deklaracja praw człowieka z 10 grudnia 1948 r., która stała się częścią tzw. międzynarodowej karty praw człowieka i podstawą opracowania paktów praw człowieka, a także wywarła wpływ na liczne dokumenty międzynarodowe, w tym traktaty powszechne i regionalne z dziedziny praw człowieka. Nie wspomina ona o bezpaństwowości, ale pośrednio dotyka tej kwestii, regulując prawo do obywatelstwa i zakaz arbitralnego pozbawiania obywatelstwa (art. 15) oraz gwarantując równość praw kobiet i mężczyzn w odniesieniu m.in. do zawierania i rozwiązania małżeństwa (art. 16 ust. 1). Generalnie postanowienia deklaracji (tak prawa osobiste i polityczne, jak i gospodarcze, socjalne i kulturalne) w pełnym zakresie stosuje się do bezpaństwowców.

Również międzynarodowe pakty praw człowieka z 16 grudnia 1966 r. $^{14}$, których Polska jest stroną ${ }^{15}$, nie różnicują zasadniczo położenia jednostki chronionej. Jedynie wyjątkowo relatywizują ją do obywatela lub cudzoziemca (np. art. 13 i 25 paktu praw obywatelskich i politycznych). Skutek prewencyjny w odniesieniu do bezpaństwowości ma np. art. 24 ust. 3 paktu praw obywatelskich i politycznych, który zobowiązuje do przyznania obywatelstwa każdemu urodzonemu pod jurysdykcją państwa dziecku ${ }^{16}$.

14 Pakt praw obywatelskich i politycznych wszedł w życie 23 marca 1976 r. Jego stronami jest 171 państw, UNTS vol. 999, s. 171; Pakt praw gospodarczych, socjalnych i kulturalnych wszedł w życie 3 stycznia 1976 r. Jego stronami jest 168 państw, UNTS vol. 993, s. 3 .

15 Pakty obowiązują od 18 czerwca 1977 r., Dz.U. nr 38, poz. 167 i 169.

16 Zob. szerzej o zastosowaniu postanowień paktu praw obywatelskich i politycznych do bezpaństwowców: International Covenant on Civil and Political Rights. Quick Reference Guide. Statelessness and Human Rights Treaties, UNHCR, October 2016, http:// www.refworld.org/pdfid/58c25e3a4.pdf. 
Z podejściem tym koresponduje art. 37 Konstytucji RP, który stanowi, że: 1. Kto znajduje się pod władza Rzeczypospolitej Polskiej, korzysta z wolności i praw zapewnionych $w$ Konstytucji.

2. Wyjątki od tej zasady, odnoszące się do cudzoziemców, określa ustawa.

Postanowienie ust. 2 jest o tyle nieścisłe, że sama Konstytucja odnosi niektóre prawa i wolności oraz obowiązki jedynie do obywateli (np. art. 35, art. 52 ust. 4, art. 55, art. 60-62, art. 67, art. 68 ust. 2, art. 82, art. 85).

Drugi poziom jest specyficznie związany z regulacją międzynarodową kwestii ograniczenia przypadków bezpaństwowości oraz położenia prawnego bezpaństwowców. Regulacja ta odbywa się w formie specyficznej (umowa dotycząca wyłącznie zagadnienia bezpaństwowości lub bezpaństwowców) albo na zasadzie pars pro toto, tj. w umowach ogólniejszej natury pojawiają się postanowienia wyraźnie dotyczące bezpaństwowości lub bezpaństwowców. Przykładami takiego ujęcia są konwencje o bezpaństwowcach, wspomniana wcześniej konwencja z 1930 r. o kolizji ustaw o obywatelstwie wraz z protokołem dotyczącym bezpaństwowości, jak również konwencja o obywatelstwie kobiet zamężnych z 20 lutego 1957 r. ${ }^{17}$, której Polska jest stroną (Dz.U. 1959, nr 56, poz. 334), czy konwencja Rady Europy o obywatelstwie z 6 listopada 1997 r. ${ }^{18}$, której Polska nie ratyfikowała.

\section{Konwencje o bezpaństwowcach a prawo polskie}

Zagadnienie relacji między konwencjami a prawem polskim zostanie przedstawione z perspektywy konkretnych pojęć i instytucji regulowanych konwencjami. Korespondujące $\mathrm{z}$ nimi prawo polskie będzie przywoływane w każdym przypadku z osobna. W wyniku porównania regulacji udzielona zostanie odpowiedź na pytanie o zgodność prawa polskiego z konwencjami, i w związku z tym ustalona ewentualna niezgodność.

Ponadto, mając na uwadze zakres regulacji konwencji o bezpaństwowcach, zasadne jest uprzednie zwrócenie uwagi na konwencję o ograniczeniu bezpaństwowości z 1961 r., a następnie konwencję o statusie bezpaństwowców z 1954 r. Podczas gdy pierwsza z nich dotyczy samego zapobiegania bezpaństwowości czy też reagowania na przypadki bezpaństwowości, druga $\mathrm{z}$ nich określa $\mathrm{w}$ szczególności standardy ochrony, jakie powinny być zapewnione bezpaństwowcom. Jedynym odstępstwem od tej zasady będzie kwestia posługiwania się terminem „bezpaństwowiec” w prawie polskim w związku z jego definicją zawartą w konwencji z 1954 r.

17 Konwencja weszła w życie 11 sierpnia 1958 r., UNTS vol. 309, s. 65. Jej stronami są 74 państwa.

18 European Treaty Series No. 166. 


\section{Pojęcie bezpaństwowca}

W obu rozważanych konwencjach kluczowym pojęciem jest pojęcie bezpaństwowca. Normuje je przede wszystkim konwencja z 1954 r., w której rozumieniu bezpaństwowcem jest osoba nieuznawana za obywatela żadnego państwa (także niebędącego stroną konwencji) w zakresie obowiązywania jego prawa (art. 1 ust. 1). Konwencja z $1961 \mathrm{r}$. nie podaje autonomicznej definicji bezpaństwowca. $\mathrm{Z}$ jej postanowień można jednak wywieść wniosek, że rozumienie to jest, co do zasady, zbieżne z definicją zawartą $\mathrm{w}$ art. 1 konwencji z $1954 \mathrm{r}$.

W praktyce międzynarodowej uważa się, że definicja bezpaństwowców z konwencji z 1954 r. dotyczy jedynie tzw. bezpaństwowców de iure. Tymczasem mamy również do czynienia z tzw. bezpaństwowcami de facto, tj. osobami, które opuściły państwo swojej przynależności i nie korzystają już z ochrony i pomocy władz krajowych, gdyż te odmawiają jej tego bądź osoba taka zrzekła się pomocy i ochrony ze strony swojego kraju albo jest niezdolna lub nie chce z ważnych przyczyn skorzystać z niej ${ }^{19}$. Definicja ta dotyczy zatem osób, które formalnie mają obywatelstwo państwa trzeciego, lecz nie korzystają z praw i nie wykonują obowiązków z nim związanych.

W prawie polskim, poza incydentalnymi przypadkami, nie używa się terminu bezpaństwowiec. Jest tak, mimo że np. dyrektywy Unii Europejskiej, które transponowano do prawa polskiego, posługują się tym terminem nawet w samych nazwach aktów. Konstytucja używa jedynie określenia „cudzoziemiec”. Z kolei w ustawie o cudzoziemcach ${ }^{20}$ stwierdza się, że cudzoziemcem jest każda osoba, która nie posiada obywatelstwa polskiego (art. 3 pkt 2). Jest nim zatem także osoba niemająca żadnego obywatelstwa, czyli bezpaństwowiec ${ }^{21}$, jak również bezpaństwowiec faktyczny. Oznacza to, że regulacje prawa polskiego dotyczące cudzoziemców (także konstytucyjne) należy stosować mutatis mutandis do bezpaństwowców. Jeśli zatem z przepisów prawa polskiego nie będzie wynikało, że z prawami, wolnościami lub obowiązkami cudzoziemca związany jest nierozerwalnie status obywatela innego państwa niż Polska, te prawa, wolności i obowiązki należy odnosić także do bezpaństwowców.

19 Zob. UNHCR, Guidelines on Statelessness No. 1: The definition of „Stateless Person" in Article 1(1) of the 1954 Convention relating to the Status of Stateless Persons, HCR/GS/12/01, 20 February 2012, http://www.refworld.org/pdfid/4f4371b82.pdf. Definicja bezpaństwowca de facto nie ma jednak charakteru legalnego. Zob. też np. M. Stiller, Statlessness in International Law: A Historic Overview, DAJV Newsletter 2012, No. 3.

20 Ustawa z 12 grudnia 2013 r. o cudzoziemcach, t.j. Dz.U. 2017, poz. 2206, ze zm. Stanowi ona w wysokim stopniu wykonanie dyrektyw Unii Europejskiej.

${ }^{21}$ Tak też na tle poprzednio obowiązującej ustawy o cudzoziemcach z 2003 r., która zawierała identyczne sformułowanie, Sąd Apelacyjny w Warszawie, w postanowieniu z 20 czerwca 2013 r., sygn. akt II AKz 429/13. 
Mniej konsekwentna od ustawy o cudzoziemcach jest ustawa o udzielaniu cudzoziemcom ochrony na terytorium Rzeczypospolitej Polskiej ${ }^{22}$. Wprawdzie zgodnie z jej art. 2 pkt 4 cudzoziemcem $w$ rozumieniu tej ustawy jest cudzoziemiec $\mathrm{w}$ rozumieniu ustawy o cudzoziemcach, a zatem zgodnie $\mathrm{z}$ przyjętą interpretacją także bezpaństwowiec, to jednak $\mathrm{w}$ dwóch dalszych przepisach wspomina się wprost o bezpaństwowcach. W ten sposób art. 21 ust. 1 pkt 6 stanowi, że cudzoziemca pozbawia się statusu uchodźcy, jeżeli po nadaniu tego statusu właściwy organ stwierdził, że cudzoziemiec, będąc bezpaństwowcem, może powrócić do państwa, w którym miał poprzednio stałe miejsce zamieszkania, z powodu ustania okoliczności, w związku z którymi uzyskał status uchodźcy, i nie przedstawił przekonywających powodów związanych z prześladowaniami, w związku z którymi uzyskał ten status, lub innych powodów uzasadnionej obawy przed prześladowaniem, uzasadniających jego odmowę powrotu do tego państwa. Z kolei w art. 22 ust. 2a stwierdza się, że cudzoziemca nie pozbawia się ochrony uzupełniającej z przyczyny, o której mowa w ust. 1 pkt 1, jeżeli może powołać się na przekonywające powody związane z poprzednio doznaną poważną krzywdą, uzasadniające jego odmowę skorzystania z ochrony państwa, którego obywatelstwo posiada, albo - w przypadku bezpaństwowca - z ochrony państwa, w którym miał poprzednio stałe miejsce zamieszkania.

Brak jednoznacznego rozróżnienia cudzoziemca i bezpaństwowca może powodować praktyczne problemy związane z odpowiednim wypełnianiem wymogów konwencyjnych.

\section{Zapobieganie bezpaństwowości}

\section{- Obowiązek nadania obywatelstwa ${ }^{23}$}

\section{- Standard konwencyjny}

Obowiązek nadania obywatelstwa został sformułowany przede wszystkim w konwencji z 1961 r. Konwencja z 1954 r. unormowała to zagadnienie ogólnie, tylko w jednym postanowieniu. Zgodnie z jej art. 32: Państwa Strony niniejszej Konwencji, $w$ takim zakresie jak to możliwe, ułatwiq asymilacje i nadanie obywatelstwa bezpaństwowca. W szczególności podejma działania mające na celu usprawnienie procedur nadawania obywatelstwa i zmniejszenie, $w$ takim stopniu jaki jest możliwy, opłat $i$ kosztów takich procedur.

Tymczasem konwencja z $1961 \mathrm{r}$. reguluje to zagadnienie w kilku postanowieniach. W art. 1 wprowadza obowiązek nadania obywatelstwa osobie urodzo-

22 Ustawa z 13 czerwca 2003 r o udzielaniu cudzoziemcom ochrony na terytorium Rzeczypospolitej Polskiej, t.j. Dz.U. 2018, poz. 51, ze zm. Ustawa wykonuje prawo unijne, ale także konwencję NZ dotyczącą statusu uchodźców.

${ }_{23}$ Zob. http://www.ohchr.org/EN/Issues/Pages/Nationality.aspx. 
nej na terytorium państwa, jeśli w przeciwnym przypadku osoba taka stałaby się bezpaństwowcem ${ }^{24}$. Nadanie takie powinno nastąpić z mocy prawa w chwili narodzin bądź na wniosek przez osobę zainteresowaną lub w jej imieniu. Odrzucenie takiego wniosku dopuszczalne jest tylko wyjątkowo, gdy uchybi się wymogom, jakie państwo nadające może sformułować zgodnie z konwencją (ust. 1). W uproszczeniu państwo może wymagać spełnienia jednego lub więcej spośród następujących wymogów: 1) wniosek powinien być złożony przez zainteresowanego między 18. a 21. rokiem życia; 2) osoba zainteresowana mieszka w państwie, gdzie składa wniosek, bezpośrednio przed złożeniem wniosku, przez okres wskazany w prawie krajowym, nie dłuższy niż 5 lat; 3) nie jest osobą podejrzaną lub skazaną za przestępstwo przeciwko bezpieczeństwu narodowemu ani skazana na karę pozbawienia wolności za przestępstwo o wymiarze co najmniej 5 lat; 4) zawsze była bezpaństwowcem (ust. 2). Ponadto dziecko, które urodziło się w związku małżeńskim, w którym matka ma obywatelstwo danego państwa, uzyskuje to obywatelstwo przez urodzenie, gdyby miało zostać bezpaństwowcem (ust. 3). Państwo zobowiązuje się też w ust. 4 do nadania obywatelstwa, jeżeli zainteresowany przekroczył wiek na złożenie wniosku albo nie spełnił wymogu domicylu, o którym mowa w ust. 2, a zarazem nie może uzyskać obywatelstwa państwa-strony, przy czym w chwili jego urodzenia jedno z rodziców miało obywatelstwo państwa, gdzie składany jest wniosek (jeżeli ich obywatelstwo było różne, decyduje się według prawa tego państwa, którego obywatelstwo powinno być nadane). Państwo może jednak wymagać spełnienia jednego lub więcej spośród następujących wymogów: 1) wniosek złożony jest przez osobę spełniającą kryterium wieku ustalone zgodnie z prawem krajowym, wynoszącym co najmniej 23 lata; 2) wnioskodawca mieszkał na terytorium państwa, gdzie składa wniosek, bezpośrednio przed złożeniem wniosku, przez określony czas, nie dłuższy niż 3 lata; 3) osoba zawsze była bezpaństwowcem (ust. 5).

Konwencja przewiduje również obowiązek nadania obywatelstwa państwa osobie urodzonej na jego terytorium, która stałaby się bezpaństwowcem w przypadku, gdy jedno z rodziców miało obywatelstwo tego państwa w chwili urodzenia (jeżeli ich obywatelstwo było różne, decyduje się według prawa tego państwa, którego obywatelstwo powinno być nadane). Nadanie takie powinno nastąpić $\mathrm{z}$ mocy prawa w chwili narodzin bądź na wniosek przez osobę zainteresowaną lub jej imieniu. Odrzucenie takiego wniosku dopuszczalne jest tylko wyjątkowo, gdy uchybi się wymogom, jakie państwo nadające może sformułować zgodnie z konwencją (ust. 1). W uproszczeniu państwo może wymagać spełnienia jednego lub więcej spośród następujących wymogów: 1) wniosek złożony jest przez osobę spełniającą kryterium wieku ustalone zgodnie z prawem krajowym, wynoszącym co najmniej 23 lata; 2) osoba zainteresowana mieszka w państwie, gdzie składa

24 Zgodnie $\mathrm{z}$ art. 3 przyjęto fikcję prawną, że poród na statku lub w samolocie oznacza poród na terytorium państwa, którego banderę statek lub samolot podnosi. 
wniosek, bezpośrednio przed złożeniem wniosku, przez okres wskazany w prawie krajowym, nie dłuższy niż 3 lata; 3) nie jest osobą skazaną za przestępstwo przeciwko bezpieczeństwu narodowemu; 4) zawsze była bezpaństwowcem (ust. 2).

Konwencja przyjmuje domniemanie wzruszalne, zgodnie z którym uznaje się, że rodzice podrzutka znalezionego na terytorium danego państwa posiadali jego obywatelstwo (art. 3).

\section{- Standard prawa polskiego}

Z przytoczonym standardem konwencyjnym korespondują niektóre przepisy ustawy o obywatelstwie polskim ${ }^{25}$, która określa zasady nabycia i utraty obywatelstwa polskiego oraz jego przywracania i potwierdzania, a także uznania za obywatela polskiego. Ustawa zna zarówno przypadek nabycia obywatelstwa z mocy prawa, jak i przez nadanie (art. 4 pkt 1 i 2). Nabycie z mocy prawa regulują art. 14 i n. ustawy. Zgodnie z art. 14 ustawy: [m]ałoletni nabywa obywatelstwo polskie przez urodzenie, w przypadku gdy: 1) co najmniej jedno z rodziców jest obywatelem polskim; 2) urodził się na terytorium Rzeczypospolitej Polskiej, a jego rodzice sa nieznani, nie posiadaja żadnego obywatelstwa lub ich obywatelstwo jest nieokreślone.

$\mathrm{W}$ obu przypadkach chroni się przed bezpaństwowością. Ponadto art. 15 ustawy stanowi, że: [m]ałoletni nabywa obywatelstwo polskie, gdy został znaleziony na terytorium Rzeczypospolitej Polskiej, a jego rodzice sa nieznani.

Pewne znaczenie dla uniknięcia bezpaństwowości dzieci ma również art. 7 ustawy. Zapewnia on, że nadanie obywatelstwa polskiego lub uznanie za obywatela polskiego rodziców dziecka obejmuje także małoletniego znajdującego się pod ich władzą rodzicielską. Jeśli dotyczy to tylko jednego z rodziców, to obejmuje to małoletniego, jeśli drugiemu z nich nie przysługuje władza rodzicielska i drugie z rodziców złożyło oświadczenie o wyrażeniu zgody na nabycie obywatelstwa przez małoletniego.

Konwencja z $1961 \mathrm{r}$. wymaga również umożliwienia nabycia obywatelstwa w określonych warunkach później niż w chwili narodzin. Przy tym w pewnym zakresie (art. 1 ust. 2 i 5, art. 4 ust. 2) daje państwu prawo sformułowania kryteriów, od których spełnienia zależy nadanie obywatelstwa na wniosek.

Z wymogami konwencyjnymi korespondują przepisy ustawy o obywatelstwie polskim dotyczące nadawania obywatelstwa polskiego (art. 18 i n.) oraz uznania za obywatela polskiego (art. 30 i n.). Przepisy te nie stanowią w żadnym razie odwzorowania postanowień konwencyjnych.

Ustawa o obywatelstwie polskim pozwala na nadawanie obywatelstwa na wniosek (art. 19). Z przepisów ustawy wynika zarazem pośrednio, że samodzielnie wniosek taki może złożyć wyłącznie osoba dorosła. Natomiast, zgodnie z art. 8, gdy wniosek dotyczy małoletniego, który ukończył 16. rok życia, konieczne jest dołączenie do wniosku oświadczenia o wyrażeniu zgody przez małoletniego.

25 Ustawa z 2 kwietnia 2009 r. o obywatelstwie polskim, t.j. Dz.U. 2017, poz. 1462, ze zm. 
Ustawa o obywatelstwie polskim nie wprowadza jednak obowiązku nadania obywatelstwa. Prezydent RP może je nadać albo odmówić nadania (art. 18, art. 25). Tymczasem konwencja z 1961 r. domaga się nadania obywatelstwa bezpaństwowcowi na wniosek, a jedynie pozwala państwu wprowadzić kryteria nadania.

Ustawa o obywatelstwie polskim zna także instytucję uznania za obywatela polskiego, którą można łączyć z konwencyjnym nadaniem obywatelstwa. Dotyczy ona siedmiu kategorii cudzoziemców wymienionych w art. 30 ust. 1 ustawy. Tutaj również formułowane są kryteria uznania w odniesieniu do poszczególnych kategorii osób. Uznanie również następuje na wniosek (art. 32). Zgodnie $\mathrm{z}$ art. 30 ust. 1 pkt 2 ustawy za obywatela polskiego uznaje się m.in.: cudzoziemca przebywajacego nieprzerwanie na terytorium Rzeczypospolitej Polskiej co najmniej od 2 lat na podstawie zezwolenia na pobyt stały, zezwolenia na pobyt rezydenta długoterminowego Unii Europejskiej lub prawa stałego pobytu, który: a) pozostaje co najmniej od 3 lat $w$ związku małżeńskim zawartym z obywatelem polskim lub b) nie posiada żadnego obywatelstwa.

Wymóg dwuletniego pobytu jest zgodny z konwencją (art. 1 ust. 2 lit. b; aczkolwiek konwencja w ramach jednego wymogu mówi o pobycie nieprzerwanym co najwyżej 5-letnim lub w sumie o 10 latach pobytu). Ustawa o obywatelstwie polskim wymaga jednak dodatkowo urzędowo potwierdzonej znajomości języka polskiego (ust. 2 art. 30; nie dotyczy on jedynie małoletniego cudzoziemca), co nie jest przewidziane konwencją z 1961 r. Ponadto odmawia się uznania cudzoziemca za obywatela polskiego (art. 31 pkt 2 ustawy) m.in. w przypadku, gdy: nabycie przez niego obywatelstwa polskiego stanowi zagrożenie dla obronności lub bezpieczeństwa państwa albo ochrony bezpieczeństwa i porządku publicznego.

Konwencja z 1961 r. dopuszcza posługiwanie się kryterium podejrzenia lub skazania (na karę pozbawienia wolności na okres co najmniej 5 lat) za przestępstwa przeciwko bezpieczeństwu narodowemu (art. 1 ust. 2 lit. c; art. 4 ust. 2 lit. c).

Ustawa nie zapewnia też wykonania art. 1 ust. 4 konwencji z 1961 r. (bezpaństwowiec niezdolny do uzyskania obywatelstwa strony konwencji, niespełniający wymagań wiekowych lub domicylu) czy art. 4 (nadanie obywatelstwa osobie, której rodzice lub rodzic w momencie narodzin byli obywatelami polskimi, a która urodziła się poza Polską).

\section{- Utrata obywatelstwa wskutek zmiany stanu cywilnego}

- Standard konwencyjny

Zagadnieniu bezpaństwowości w razie utraty obywatelstwa poświęcono w konwencji z 1961 r. art. 5 i 6. Pierwszy z nich dotyczy utraty obywatelstwa wskutek zmiany statusu cywilnego osoby. Jeżeli prawo krajowe przewiduje taką sytuację, to utrata może nastąpić wyłącznie wówczas, gdy osoba taka uzyska lub ma obywatelstwo innego państwa. Gdy utrata dotyczy nieślubnego dziecka, powinno ono mieć możliwość odzyskania obywatelstwa na wniosek i z poszanowaniem 
wymogów, które nie będą bardziej rygorystyczne niż te z art. 1 ust. 2 konwencji (art. 5). Artykuł 6 konwencji odnosi się do pochodnej utraty obywatelstwa, tj. przypadku, gdy utrata obywatelstwa przez małżonka lub dzieci wynika $\mathrm{z}$ utraty obywatelstwa zainteresowanej osoby. $\mathrm{W}$ takim wypadku prawo krajowe także powinno uzależniać utratę od posiadania lub nabycia innego obywatelstwa.

\section{- Standard prawa polskiego}

Ustawa o obywatelstwie polskim przewiduje, że:

- w odniesieniu do zawarcia związku małżeńskiego przez obywatela polskiego z cudzoziemcem nie powoduje ono zmian w obywatelstwie małżonków (art. 5), a zatem ani mąż, ani żona nie traçą ewentualnie posiadanego obywatelstwa polskiego; ustawa nie zawiera analogicznego rozwiązania $\mathrm{w}$ razie rozwodu lub unieważnienia małżeństwa,

- zmiany w ustaleniu osoby albo obywatelstwa jednego lub obojga rodziców podlegają uwzględnieniu przy określeniu obywatelstwa małoletniego, jeżeli nastąpiły przed upływem roku od dnia urodzenia się małoletniego (art. 6 ust. 1); ustawa nie wskazuje, co dzieje się, gdy z ustalenia obywatelstwa rodziców wynika, że nie mają żadnego obywatelstwa,

- w odniesieniu do sądowego ustalenia osoby ojca (zaprzeczenie ojcostwa, unieważnienie uznania) - uwzględnia się je przy określeniu obywatelstwa małoletniego, chyba że małoletni osiągnął już pełnoletność lub za jego zgodą, jeżeli ukończył 16 lat (art. 6 ust. 2); ustawa nie wskazuje, co dzieje się, gdy ze zmian dotyczących ojca wynika, że dziecko staje się bezpaństwowcem,

- małoletni cudzoziemiec, przysposobiony przez osobę lub osoby posiadające obywatelstwo polskie, nabywa obywatelstwo polskie, jeżeli przysposobienie pełne nastąpiło przed ukończeniem przez niego 16 lat; w tym wypadku przyjmuje się, że małoletni cudzoziemiec nabył obywatelstwo polskie z dniem urodzenia (art. 16).

Z przepisów ustawy wynika, że nie zapewniają one utrzymania obywatelstwa polskiego $\mathrm{w}$ sytuacji, gdy zmiany związane z małżeństwem prowadziłyby do bezpaństwowości.

- Zrzeczenie się obywatelstwa, ubieganie się o obce obywatelstwo, utrata obywatelstwa na skutek wyjazdu, zamieszkiwania zagranicą, braku zameldowania i innych zdarzeń podobnych

- Standard konwencyjny

Artykuł 7 konwencji z 1961 r. dotyczy zrzeczenia się obywatelstwa. Jeśli zatem prawo krajowe dopuszcza zrzeczenie, to takie zrzeczenie nie powinno powodować bezpaństwowości. Jednak postanowienia tego nie stosuje się, gdyby naruszało ono art. 13 i 14 Powszechnej deklaracji praw człowieka. Podobnie - ubieganie 
się o obce obywatelstwo nie może prowadzić do bezpaństwowości. Osoba taka powinna zatem uzyskać takie obywatelstwo lub otrzymać decyzję, że zostanie mu ono nadane (art. 7 ust. 1 i 2 konwencji).

Zainteresowany nie powinien też tracić obywatelstwa, stając się bezpaństwowcem, na skutek wyjazdu, zamieszkiwania zagranicą (chyba że chodzi o obywatela z naturalizacji, który mieszka zagranicą co najmniej 7 kolejnych lat i nie składa oświadczenia o zamiarze zachowania obywatelstwa), braku zarejestrowania i innych zdarzeń podobnych. Ponadto w przypadku osób urodzonych zagranicą można uzależnić zachowanie obywatelstwa od zamieszkania w czasie osiągnięcia dojrzałości w tym państwie lub zarejestrowania. Niezależnie od tego osoba nie może utracić obywatelstwa, stając się bezpaństwowcem, $\mathrm{z}$ innych niezakazanych wyraźnie w konwencji powodów (ust. 3-5).

- Standard prawa polskiego

Ustawa o obywatelstwie reguluje problematykę zrzeczenia się obywatelstwa $\mathrm{w}$ art. 46 i n. Zrzeczenie się jest zatem dopuszczalne tylko za zgodą Prezydenta RP (art. 46 i 47). Ustawa nie zawiera gwarancji, że takie zrzeczenie nie doprowadzi do bezpaństwowości.

Ustawa nie przewiduje innych przypadków utraty obywatelstwa, poza zrzeczeniem się (zob. też art. 34 ust. 2 Konstytucji).

\section{- Pozbawienie obywatelstwa}

\section{- Standard konwencyjny}

Państwo-strona konwencji z 1961 r. nie może pozbawić obywatelstwa, jeśli jego skutkiem będzie bezpaństwowość (art. 8 ust. 1). Konwencja przewiduje w tym artykule, że pozbawienie obywatelstwa może nastąpić tylko na określonych warunkach (art. 7 ust. 4 i 5, uzyskanie obywatelstwa nastąpiło na skutek świadomego wprowadzenia w błąd lub oszustwa). Ponadto państwo może zachować prawo pozbawienia obywatelstwa przez złożenie deklaracji zgodnie z ust. 3 art. 8, tj. w razie naruszenia obowiązku lojalności lub złożenia przysięgi lub oświadczenia o wierności wobec innego państwa. Pozbawienie obywatelstwa $\mathrm{w}$ innych przypadkach powinno być niedozwolone, a samo powinno zachowywać standardy określenia pozbawienia obywatelstwa w ustawie, a także prawa do obrony. Ponadto, zgodnie z art. 9 konwencji, nie można pozbawiać osoby lub grupy osób obywatelstwa z powodów rasowych, etnicznych, religijnych lub politycznych.

- Standard prawa polskiego

Prawo polskie nie przewiduje pozbawienia obywatelstwa polskiego (art. 34 ust. 2 Konstytucji). Akty tego rodzaju stanowiłyby naruszenie Konstytucji i ustaw. Oznacza to, że prawo polskie jest zgodne z wymogami konwencyjnymi. 


\section{- Cesja terytorialna}

- Standard konwencyjny

Konwencja z 1961 r. przewiduje również zobowiązanie włączenia do zawieranych przez siebie (także z państwem niebędącym stroną) traktatów cesji terytorialnej klauzuli pozwalającej zachować osobom dotkniętym transferem obywatelstwo. Jeśli taka klauzula nie zostanie włączona, należy nadać osobom zainteresowanym obywatelstwo, jeśli miałyby stać się bezpaństwowcami (art. 10 konwencji).

- Standard prawa polskiego

Prawo polskie nie odnosi się do kwestii bezpaństwowości w przypadku cesji terytorialnej. Materia ta podlega ewentualnej regulacji umownej. Oznacza to, że w zakresie, w jakim konwencja wymaga zapewnienia, że nie dojdzie do bezpaństwowości w razie braku odpowiedniej klauzuli w umowie cesji terytorialnej, ustawodawstwo polskie nie spełnia standardu konwencyjnego.

\section{Standardy ochronne określające status prawny bezpaństwowca}

\section{- Zasady ogólne}

- Standard konwencyjny

Konwencja z 1954 r. wymienia najpierw kilka zasad ogólnych o zróżnicowanym charakterze. Formułuje ogólne zobowiązanie dla każdego bezpaństwowca przede wszystkim do przestrzegania prawa i porządku publicznego państwa przyjmującego (art. 1). Ponadto ustanawia ogólne standardy traktowania bezpaństwowców: 1) zakaz dyskryminacji z uwagi na rasę, religię, państwo pochodzenia; 2) standard traktowania narodowego co do wolności praktyk religijnych i edukacji religijnej dzieci (art. 3 i 4). Konwencja wyznacza minimalny standard traktowania bezpaństwowców, tj. tak jak cudzoziemców, chyba że konwencja zawiera rozwiązania bardziej korzystne. Poza tym zawiera regulację dotyczącą zwolnienia spod reguły traktowania na zasadzie wzajemności (art. 7). Ustanawia możliwości poszerzania ochrony, także uwzględniania ochrony pozakonwencyjnej (art. 7 ust. 3 i 4, art. 5). Do bezpaństwowców nie stosuje się środków wyjątkowych tylko dlatego, że byli uprzednio obywatelami obcego państwa, wobec którego podejmuje się takie środki (art. 8). Zarazem dopuszcza się stosowanie środków tymczasowych w razie wojny lub innych poważnych i wyjątkowych okoliczności, koniecznych ze względu na bezpieczeństwo wewnętrzne (art. 9) ${ }^{26}$.

26 Pomijam postanowienia art. 10 (kontynuacja zamieszkiwania w razie przesiedleńców z II wojny światowej) i art. 11 (marynarzy bezpaństwowców - obowiązek ułatwień w uzyskaniu obywatelstwa). 
Konwencja z 1954 r. posługuje się w szczegółowych rozwiązaniach dotyczących położenia bezpaństwowców dwoma standardami: standardem traktowania narodowego $(\mathrm{KN})$ oraz standardem najwyższego uprzywilejowania (KNU). Pierwszy z nich nakazuje traktowanie tak jak własnych obywateli, drugi - jak cudzoziemców w takich samych okolicznościach (wyjaśnia też rozumienie tego ostatniego określenia w art. 6; chodzi o wymogi domicylu - długości i warunków pobytu lub zamieszkania).

W tym kontekście należy pamiętać, że w przypadku Polski jako państwa członkowskiego Unii Europejskiej, dla standardu traktowania narodowego punktem odniesienia jest nie tylko traktowanie obywateli polskich, lecz również, co do zasady, obywateli państw członkowskich UE (ich traktowanie nie oznacza traktowania cudzoziemców w rozumieniu konwencji z 1954 r.). Standard najwyższego uprzywilejowania oznacza zatem porównanie z obywatelami państw trzecich (spoza Unii Europejskiej).

- Standard prawa polskiego

W odniesieniu do zakazu dyskryminacji bezpaństwowców (art. 3 konwencji z 1954 r.) Konstytucja zakazuje dyskryminacji w szerszym zakresie, nie różnicując uprawnionych i nie ograniczając kryteriów niedozwolonej dyskryminacji (art. 32 Konstytucji). Co do gwarancji wolności religijnej w zakresie ustalonym konwencją (art. 4), w art. 53 Konstytucji zawarta jest odpowiednia reguła gwarancyjna, nieróżnicująca osób w zakresie statusu obywatelskiego. Co więcej, ustawa o gwarancjach wolności sumienia i wyznania ${ }^{27}$ wyraźnie przewiduje w art. 7, że cudzoziemcom, a także bezpaństwowcom przebywającym na terytorium RP zapewnia się korzystanie z wolności sumienia i wyznania na równi z obywatelami polskimi (standard traktowania narodowego), co wypełnia wymogi konwencyjne.

Konwencja z 1954 r. traktuje bezpaństwowców tak jak cudzoziemców, chyba że zawiera rozwiązania bardziej korzystne. Także polska ustawa o cudzoziemcach obejmuje zakresem swojej regulacji bezpaństwowców.

Prawo polskie nie przewiduje też szczególnego (niekorzystnego) traktowania bezpaństwowców w razie stanu wojennego (art. 18 i n. ustawy o stanie wojennym oraz o kompetencjach Naczelnego Dowódcy Sił Zbrojnych i zasadach jego podległości konstytucyjnym organom Rzeczypospolitej Polskiej ${ }^{28}$, wyjątki dotyczą swobody wjazdu i pobytu oraz mienia - art. 7 ust. 2, art. 28 ust. 1 pkt 3) czy stanu wyjątkowego (art. 21 ustawy o stanie wyjątkowym ${ }^{29}$ ). W tym względzie

27 Ustawa z 17 maja 1989 r. o gwarancjach wolności sumienia i wyznania, t.j. Dz.U. 2017, poz. 1153.

28 Ustawa z 29 sierpnia 2002 r. o stanie wojennym oraz o kompetencjach Naczelnego Dowódcy Sił Zbrojnych i zasadach jego podległości konstytucyjnym organom Rzeczypospolitej Polskiej, t.j. Dz.U. 2017, poz. 1932.

29 Ustawa z 21 czerwca 2002 r. o stanie wyjątkowym, t.j. Dz.U. 2017, poz. 1928. 
jednak pełna ocena zgodności z konwencją (art. 8 i 9) byłaby możliwa dopiero przy uwzględnieniu praktyki stosowania przepisów ustawowych.

\section{- Status prawny}

- Standard konwencyjny

Zasadą ogólną jest, że status osobowy bezpaństwowca jest regulowany prawem państwa przyjmującego, a prawa nabyte $\mathrm{z}$ nim związane, zwłaszcza wynikające $\mathrm{z}$ małżeństwa, muszą być szanowane przez państwo przyjmujące, zgodnie $\mathrm{z}$ art. 12 konwencji z $1954 \mathrm{r}$. Ponadto konwencja przewiduje: 1) w stosunku do mienia nieruchomego i ruchomego - KNU; 2) własności intelektualnej i przemysłowej - KN; 3) prawa zrzeszania się $\mathrm{w}$ organizacje inne niż polityczne, nienastawione na zysk oraz w związki zawodowe - KNU; 4) prawa do sądu - KN (art. 13-16 konwencji).

\section{- Standard prawa polskiego}

W odniesieniu do statusu osobowego bezpaństwowców stosuje się niewątpliwie prawo polskie. Dotyczy to np. ustawy - Prawo o aktach stanu cywilnego ${ }^{30}$ (jako do cudzoziemców). Także Kodeks cywilny ${ }^{31} \mathrm{w}$ zakresie prawa osobowego, rzeczowego i spadkowego stosuje się do bezpaństwowców (jako do osób fizycznych). W przypadku nabywania nieruchomości przez bezpaństwowców stosuje się wszakże ustawę o nabywaniu nieruchomości przez cudzoziemców ${ }^{32}$. Ustawa ta dotyczy cudzoziemców, ale należy ją odnosić także do bezpaństwowców (art. 1 ust. 2 pkt 1). Wprawdzie wprowadza ona ograniczenia, ale nie różnicuje statusu bezpaństwowca i cudzoziemca, co spełnia standard konwencyjny.

Jeśli chodzi o prawo własności intelektualnej i przemysłowej, to zastosowanie znajduje najpierw ustawa o prawie autorskim i prawach pokrewnych (bezpaństwowiec będący podmiotem prawa autorskiego w rozumieniu art. $8 \mathrm{in}$. ${ }^{33}$. Ponadto znaczenie ma ustawa - Prawo własności przemysłowej ${ }^{34}$. W tym wypadku ustawa wyróżnia kategorię osób zagranicznych, do której należą m.in. osoby niemające obywatelstwa polskiego (art. 3 ust. 1 pkt 2). Jeśli nie ma odpowiednich umów międzynarodowych, to mogą one korzystać z praw i ochrony wynikających $\mathrm{z}$ ustawy na zasadzie wzajemności. Konwencja jednak wymaga, aby wobec

30 Ustawa z 28 listopada 2014 r. - Prawo o aktach stanu cywilnego, t.j. Dz.U. 2016, poz. 2064, ze zm.

31 Ustawa z 23 kwietnia 1964 r. - Kodeks cywilny, t.j. Dz.U. 2018, poz. 1025.

32 Ustawa z 24 marca 1920 r. o nabywaniu nieruchomości przez cudzoziemców, t.j. Dz.U. 2017, poz. 2278.

33 Ustawa z 4 lutego 1994 r. o prawie autorskim i prawach pokrewnych, t.j. Dz.U. 2017, poz. 880 , ze zm.

34 Ustawa z 20 lipca 2000 r. - Prawo własności przemysłowej, t.j. Dz.U. 2017, poz. 776. 
bezpaństwowców nie stosować przynajmniej po upływie 3 lat wymogu wzajemności (art. 7 ust. 2).

W odniesieniu do zrzeszania się ustawa - Prawo o stowarzyszeniach ${ }^{35}$ stano- $^{-}$ wi w art. 4, że: 1. Cudzoziemcy mający miejsce zamieszkania na terytorium Rzeczypospolitej Polskiej moga zrzeszać się $w$ stowarzyszeniach, zgodnie z przepisami obowiązujacymi obywateli polskich. 2. Cudzoziemcy niemajacy miejsca zamieszkania na terytorium Rzeczypospolitej Polskiej moga wstępować do stowarzyszeń, które przewiduja taka możliwość.

Konwencja z 1954 r. wymaga traktowania bezpaństwowców jak cudzoziemców (art. 15). W rezultacie polska regulacja nie narusza standardu konwencyjnego.

\section{- Zatrudnienie i wynagrodzenie}

- Standard konwencyjny

Gdy chodzi o sferę stosunków pracy, to konwencja z 1954 r. ustanawia następujące standardy traktowania bezpaństwowców: 1) prawo do zatrudnienia za wynagrodzeniem - KNU (z obowiązkiem rozpatrzenia zbliżenia do KN); 2) prawo do samozatrudnienia - KNU; 3) prawo do wykonywania wolnych zawodów - KNU (art. 17-19).

- Standard prawa polskiego

W kwestii zatrudniania i wynagradzania do bezpaństwowców stosuje się przepisy dotyczące zatrudniania cudzoziemców w Polsce z ustawy o promocji zatrudnienia i instytucjach rynku pracy (art. 1 ust. 3) ${ }^{36}$. Ustawa nie wspomina wprost o bezpaństwowcach, ale można ich lokować w różnych kategoriach ustawowych cudzoziemców (art. 2 ust. 1 pkt 7). Konwencja z 1954 r. wymaga traktowania takiego jak cudzoziemców, co ustawa gwarantuje.

$\mathrm{W}$ odniesieniu do samozatrudnienia oraz w zakresie wykonywania wolnych zawodów przez bezpaństwowców znaczenie mają ustawa - Prawo przedsiębiorców $^{37}$ oraz ustawa o zasadach uczestnictwa przedsiębiorców zagranicznych i innych osób zagranicznych w obrocie gospodarczym na terytorium Rzeczypospolitej Polskiej ${ }^{38}$. Pierwsza z nich, niezrelatywizowana wyraźnie do cudzoziemców (i bezpaństwowców), nie wprowadza rozróżnienia między obywatelami a cudzoziemcami, kierując się kryterium przedsiębiorcy działającego na terytorium RP i nakazując równe traktowanie wszystkich przedsiębiorców (jest nim także oso-

35 Ustawa z 7 kwietnia 1989 r. - Prawo o stowarzyszeniach, t.j. Dz.U. 2017, poz. 210, ze zm.

36 Ustawa z 20 kwietnia 2004 r. o promocji zatrudnienia i instytucjach rynku pracy, t.j. Dz.U. 2017, poz. 1065, ze zm.

37 Ustawa z 6 marca 2018 r. - Prawo przedsiębiorców, Dz.U. poz. 646.

38 Ustawa z 6 marca 2018 r. o zasadach uczestnictwa przedsiębiorców zagranicznych i innych osób zagranicznych w obrocie gospodarczym na terytorium Rzeczypospolitej Polskiej, Dz.U. poz. 649. 
ba fizyczna) w zakresie podejmowania, wykonywania i zakończenia działalności (art. 1, 3 i 4 ustawy).

Druga z ustaw, dotycząca tak działalności gospodarczej, jak i świadczenia usług, tworzy jednak rozwiązania szczególne dotyczące zwłaszcza cudzoziemców rozumianych w niej jako osoby zagraniczne działające na terytorium RP (art. 1 i 2). Przy tym w odniesieniu do działalności gospodarczej ustawa wprowadza $\mathrm{w}$ art. 4 rozróżnienie $\mathrm{w}$ standardzie traktowania na osoby zagraniczne z państw członkowskich Unii Europejskiej lub Europejskiego Obszaru Gospodarczego oraz inne osoby zagraniczne, aczkolwiek wszystkim zapewnia traktowanie narodowe. Trzeba zauważyć, że w ustawie istnieje wada legislacyjna (niespójność), gdyż art. 3 pkt 5 lit. a wskazuje, że osobą zagraniczną jest m.in. osoba fizyczna nieposiadająca obywatelstwa polskiego, a zatem teoretycznie także bezpaństwowiec. Tymczasem art. 4, który wyznacza standard traktowania, ogranicza standard traktowania do obywateli innych państw, a nie osób zagranicznych z innych państw niż państwa członkowskie UE/EOG. Oznacza to, że ustawa nie spełnia wymagań konwencji z 1954 r. W stosunku do świadczenia usług ustawa stanowi, że osoby zagraniczne inne niż z państw członkowskich UE/EOG mogą czasowo świadczyć usługi na zasadach określonych w wiążących RP umowach międzynarodowych, a w ich braku na zasadzie wzajemności (art. 5). I w tym przypadku powstaje sprzeczność z konwencją z 1954 r., ponieważ nie uzależnia ona świadczenia usług od istnienia umów międzynarodowych, a ponadto domaga się zwolnienia z wymogu wzajemności, przynajmniej po upływie 3 lat od uzyskania legalnego zamieszkania na terytorium państwa-strony (art. 7).

Ustawa o cudzoziemcach wskazuje też na wymogi wstępne dotyczące zatrudnienia lub wykonywania działalności gospodarczej, w tym wolnych zawodów (np. art. 142 i n.), które stosuje się jednakowo do cudzoziemców i bezpaństwowców. Odpowiada to wymogom konwencyjnym.

\section{- Opieka społeczna}

- Standard konwencyjny

W dziedzinie opieki socjalnej konwencja wymaga: 1) w razie sytuacji niedostatku produktów - KN; 2) zakwaterowania - KNU; 3) edukacji publicznej podstawowej - KN, ponadpodstawowej (dostęp do nauki, ale też uznawanie dyplomów i stopni, stypendiów, kosztów i opłat) - KNU; 4) pomocy ze środków publicznych $\mathrm{KN}$; 5) standardy prawa pracy i zabezpieczenia społecznego - KN (art. 17-24).

- Standard prawa polskiego

W odniesieniu do korzystania przez bezpaństwowców z pomocy państwa znaczenie ma ustawa o pomocy społecznej ${ }^{39}$. Ustawa obejmuje nią niektóre, wąskie

39 Ustawa z 12 marca 2004 r. o pomocy społecznej, t.j. Dz.U. 2017, poz. 1769, ze zm. 
kategorie cudzoziemców (art. 5 pkt 2, art. 5a), nie wskazując jednak wyraźnie, że chodzi tutaj także o bezpaństwowców. Regulacja ta pozostaje niejasna co do jej zastosowania wobec bezpaństwowców (wyraźnie większy nacisk kładzie się na uchodźców lub osoby znajdujące się w sytuacji szczególnej, czasowej). Tymczasem konwencja wymaga zapewnienia traktowania narodowego.

W zakresie prawa pracy i zabezpieczenia społecznego stosuje się ustawy Kodeks pracy ${ }^{40}$ oraz ustawę o systemie ubezpieczeń społecznych ${ }^{41}$. Ustawy te stosują kryterium podmiotowe niezwiązane z obywatelstwem. Nie wydaje się zatem, aby standard traktowania bezpaństwowców odbiegał od traktowania obywateli, czego wymaga konwencja.

Jeśli chodzi o szkolnictwo, Konstytucja gwarantuje prawo do nauki, lecz stwierdza, że władze publiczne zapewniają obywatelom powszechny i równy dostęp do wykształcenia (art. 70 ust. 4). Z kolei ustawa - Prawo oświatowe ${ }^{42}$ nie różnicuje w statusie obywateli i cudzoziemców (bezpaństwowców), obejmując obowiązkiem szkolnym dzieci w wieku 7 lat do 18. roku życia albo ukończenia szkoły ponadpodstawowej i nakazując traktowanie osób niebędących obywatelami polskimi tak jak obywateli polskich (art. 35 ust. 2, art. 165 ust. 1 i 2), co wykracza poza wymogi konwencyjne. W przypadku szkolnictwa wyższego ustawa Prawo o szkolnictwie wyższym ${ }^{43}$ przewiduje odmienne od obywateli traktowanie cudzoziemców (w tym bezpaństwowców, art. 43), różnicując jednak traktowanie w obrębie cudzoziemców (ust. 2). Nie koresponduje to z konwencją z 1954 r.

\section{- Środki administracyjne}

- Standard konwencyjny

W sferze stosowania środków administracyjnych konwencja z 1954 r. wymaga, aby państwa-strony zapewniły pomoc administracyjną, jeśli korzystanie z praw przez bezpaństwowca wymaga pomocy. Chodzi tutaj w szczególności o dostarczanie niezbędnych dokumentów lub świadectw. Wszelkie opłaty z tytułu czynności administracyjnych muszą być umiarkowane, porównywalne do pobieranych za podobne usługi od obywateli (art. 25). Ponadto konwencja domaga się KNU w odniesieniu do swobody przemieszczania się (istnieje obowiązek wydania koniecznych dokumentów tożsamości osobom nieposiadającym ważnego dokumentu, a także co do zasady dokumentów podróży, art. 26-28). W kwestii opodatkowania i ceł konwencja wprowadza standard traktowania na-

40 Ustawa z 26 czerwca 1974 r. - Kodeks pracy, t.j. Dz.U. 2018, poz. 917, ze zm.

41 Ustawa z 13 października 1998 r. o systemie ubezpieczeń społecznych, t.j. Dz.U. 2017, poz. 1778 , ze zm.

42 Ustawa z 14 grudnia 2016 r. - Prawo oświatowe, t.j. Dz.U. 2018, poz. 996, ze zm.

43 Ustawa z 27 lipca 2005 r. - Prawo o szkolnictwie wyższym, t.j. Dz.U. 2017, poz. 2183, ze zm. 
rodowego (art. 29). Co do transferu aktywów nabytych w państwie, w którym bezpaństwowcy otrzymali zezwolenie na przesiedlenie, konwencja wymaga jego umożliwienia (art. 30). Wreszcie, co do wydalenia, konwencja ustanawia zasadę, że może ono nastąpić jedynie w przypadkach uzasadnionych względami bezpieczeństwa narodowego lub publicznego. Wydalenie może mieć miejsce tylko na podstawie decyzji wydanej zgodnie z odpowiednią procedurą prawną. Co do zasady bezpaństwowiec ma też mieć prawo do obrony i reprezentacji. W razie wydalenia może być wprowadzany okres karencji (art. 31).

\section{- Standard prawa polskiego}

Konwencja z 1954 r. wymaga udzielenia pomocy bezpaństwowcom w sprawach administracyjnych. W Polsce może być ona świadczona na zasadach ogólnie mających zastosowanie do cudzoziemców. Prawo polskie nie przewiduje szczególnych rozwiązań dla bezpaństwowców.

W odniesieniu do swobody przemieszczania się bezpaństwowców, łącznie z obowiązkiem wydawania dokumentów tożsamości czy dokumentów podróży, znaczenie ma ustawa o cudzoziemcach. Tak jak w wielu innych przypadkach ustawa nie rozróżnia cudzoziemca i bezpaństwowca (art. 226 i n.). Ustawa przewiduje możliwość wydania na wniosek cudzoziemca polskich dokumentów tożsamości i dokumentów podróży cudzoziemcowi (art. 226 i 229). Oznacza to, że ustawa nie gwarantuje niezbędnej ochrony bezpaństwowcowi, wobec którego konwencja z 1954 r. wymaga wydania dokumentów tożsamości, jeśli nie ma ważnych dokumentów podróży (art. 27). Konwencja odróżnia też dokumenty tożsamości (co do wydania których jest bardziej rygorystyczna) i dokumenty podróży (co do których dopuszcza odstępstwa z uwagi na ochronę bezpieczeństwa narodowego i porządku publicznego, art. 28).

Jednym z zagadnień uregulowanych konwencją z 1954 r. jest też ochrona bezpaństwowców legalnie przebywających na terytorium państwa-strony przed wydaleniem (art. 31). W tej materii ustawodawstwo polskie, zwłaszcza ustawa o cudzoziemcach, nie przewiduje szczególnego traktowania bezpaństwowców. Stosuje się do nich zasady dotyczące cudzoziemców. Przy tym ustawa wprowadziła w miejsce decyzji o wydaleniu konstrukcję decyzji zobowiązującej cudzoziemca do powrotu (art. 299 i n. $)^{44}$. Przyczyny wydania takiej decyzji określa bardzo rozbudowany art. 302 ustawy. Szerzej widziane są tu przyczyny związane z ochroną interesów narodowych. Ustawa wymienia bowiem: względy obronności lub bezpieczeństwa państwa lub ochrony bezpieczeństwa i porzadku publicznego lub interes Rzeczypospolitej Polskiej (ust. 1 pkt 9). Oznacza to niedostosowanie do konwencji, która aprobuje jedynie względy bezpieczeństwa narodowego lub

${ }^{44}$ Wyjątek odnosi się do ustawy z 14 lipca 2006 r. o wjeździe na terytorium Rzeczypospolitej Polskiej, pobycie oraz wyjeździe z tego terytorium obywateli państw członkowskich Unii Europejskiej i członków ich rodzin, t.j. Dz.U. 2017, poz. 900, ze zm. 
bezpieczeństwa publicznego (art. 31 ust. 1). Natomiast ustawa z pewnością spełnia wymogi proceduralne stawiane w konwencji.

Co do podatków i ceł, Polska ustanawia samodzielnie jedynie podatki (na zasadzie zharmonizowanej). W zakresie ceł stosuje się rozporządzenia Unii Europejskiej. Gdy chodzi o podatki, zwłaszcza podatek dochodowy od osób fizycznych, to ustawę o podatku dochodowym od osób fizycznych ${ }^{45}$ stosuje się tylko do osób fizycznych osiągających na terytorium RP (w rozumieniu art. 5) dochody w rozumieniu art. 3 ustawy. Ustawa ta nie rozróżnia pod tym względem cudzoziemców i bezpaństwowców, stosując do nich formalnie standard traktowania narodowego (pewne znaczenie ma miejsce zamieszkania, ale jest ono istotne tylko o tyle, o ile trzeba ustalić, jaki dochód podlega opodatkowaniu).

\section{Bibliografia}

Nascimbene B., Le droit de la nationalité et le droit des organisations d'intégration régionales. Vers de nouveaux statuts de résidents?, RCADI 2013, vol. 367, https://doi. org/10.1163/ej.9789004267930.253-414.

Stiller M., Statlessness in International Law: A Historic Overview, DAJV Newsletter 2012, No. 3.

UNHCR, Guidelines on Statelessness No. 1: The definition of „Stateless Person” in Article 1(1) of the 1954 Convention relating to the Status of Stateless Persons, HCR/GS/12/01, 20 February 2012, http://www.refworld.org/pdfid/4f4371b82.pdf.

Worster W.T., The Presumption of Customary International Law: A Case Study of Child Stateleness, https://papers.ssrn.com/sol3/papers.cfm?abstract_id=3091912, https:// doi.org/10.2139/ssrn.3091912.

45 Ustawa z 26 lipca 1991 r. o podatku dochodowym od osób fizycznych, t.j. Dz.U. 2018, poz. 200, ze zm. 


\title{
Projekt budżetu ogólnego Unii Europejskiej na rok budżetowy 2019 - Ogólne wprowadzenie - Ogólne zestawienie dochodów - Zestawienie dochodów i wydatków w podziale na sekcje ${ }^{1}$
}

\begin{abstract}
Draft General Budget of the European Union for the financial year 2019 - General introduction - General statement of revenue - Statement of revenue and expenditure by section (WASiE/WAPM-1832/18): The opinion presents the most important assumptions of the Draft General Budget of the EU for the fiscal year 2019. The document contains description of priorities adopted during drafting, planned revenues, expenditures, and changes over time (compared to the previous budget) in the projected amounts. The Polish government's position on the 2019 Draft General Budget is positively assessed, including the government's statement that during the work on the budget it will be striving for provision of the financial resources necessary to repay the liabilities contracted earlier by the Member States on behalf of the EU budget (it is particularly related to cohesion policy and development of rural areas - both being very important investment instruments in the EU).
\end{abstract}

Keywords: budget, European Union

Słowa kluczowe: budżet, Unia Europejska

* Doktor nauk ekonomicznych, naczelnik Wydziału Analiz Społecznych

i Ekonomicznych BAS; zofia.szpringer@sejm.gov.pl.

* Doktor nauk prawnych, adiunkt w Katedrze Prawa Administracyjnego i Samorządu Terytorialnego WPiA UKSW; naczelnik Wydziału Analiz Prawa Europejskiego i Międzynarodowego BAS; ziemowit.cieslik@sejm.gov.pl.

$1 \quad$ Opinia w sprawie projektu budżetu ogólnego Unii Europejskiej na rok budżetowy 2019 Ogólne wprowadzenie - Ogólne zestawienie dochodów - Zestawienie dochodów i wydatków w podziale na sekcje sporządzona 16 lipca 2018 r. na zlecenie przewodniczącej Komisji do Spraw Unii Europejskiej; BAS-WASiE/WAPM 1832/18. 


\section{Opinia merytoryczna}

\section{Przedmiot dokumentu UE}

\section{- Treść dokumentu UE}

Zaproponowany projekt budżetu ogólnego na rok $2019^{2}$ będzie szóstym, a zarazem przedostatnim budżetem $w$ ramach obecnych wieloletnich ram finansowych (WRF) dotyczących lat 2014-2020. Będzie on wykonywany w roku wyborów do Parlamentu Europejskiego oraz w czasie wychodzenia z Unii Europejskiej Zjednoczonego Królestwa, co nie oznacza jednak, że kraj ten nie będzie partycypował w tym i kolejnym jeszcze budżecie ${ }^{3}$.

Komisji Europejskiej zależy na terminowym przyjęciu budżetu, po to by zapewnić stabilność, przewidywalność i ciągłość warunków obecnej ścieżki dochodzenia UE do zrównoważonego wzrostu i spójności gospodarczej.

Dlatego też w tym budżecie nadal będzie wspieranych dziesięć priorytetów politycznych wskazanych przez przewodniczącego Komisji Europejskiej C. Junckera na początku jego kadencji, z położeniem nacisku na inwestowanie w silniejszą i odporniejszą gospodarkę europejską oraz na promowanie solidarności i bezpieczeństwa po obu stronach unijnych granic ${ }^{4}$. Ponadto uwzględnione zostały wytyczne Rady i Parlamentu przyjęte w dniach 20 lutego i 9 marca 2018 r. ${ }^{5}$.

Http://eur-lex.europa.eu/budget/www/index-pl.htm.

3 Zgodnie z art. 50 Traktatu o Unii Europejskiej Zjednoczone Królestwo powiadomiło o swoim zamiarze wystąpienia z UE z dniem 30 marca 2019 r. Niemniej na potrzeby projektu budżetu na 2019 r. Zjednoczone Królestwo traktowane jest jak państwo członkowskie. W pkt 59 wspólnego sprawozdania negocjatorów UE i rządu Zjednoczonego Królestwa oraz komunikatu Komisji do Rady Europejskiej (COM(2017)784 final, 8 grudnia 2017 r.) stwierdzono, że Zjednoczone Królestwo wnosi wkład do budżetów rocznych Unii na lata 2019 i 2020 oraz uczestniczy w ich wykonaniu, jak gdyby nadal było członkiem Unii.

$4 \quad$ W tym też aspekcie podkreślono znaczenie Europejskiego Funduszu na rzecz Inwestycji Strategicznych (EFIS). Wskazano bowiem, że EFIS, który był utworzony w 2015 r., do kwietnia 2018 r. osiągnął 90\% swojego pierwotnego celu, jakim jest uruchomienie 315 mld euro na potrzeby inwestycji infrastrukturalnych i innowacji. We wszystkich państwach UE podpisane zostały umowy finansowe i oczekuje się, że 611 tys. małych i średnich przedsiębiorstw będzie miało dostęp do finansowania pozyskanego dzięki gwarancjom publicznym zapewnionym przez budżet UE. We wszystkich państwach członkowskich zwiększył się poziom inwestycji oraz tempo wzrostu, co proporcjonalnie przełożyło się na większą liczbę miejsc pracy. W 2017 r. wzrost w UE wynosił 2,4\% i był najwyższy w ciągu ostatnich 10 lat, a w marcu 2018 r. stopa bezrobocia osiągnęła $7,1 \%$, czyli poziom najniższy od 10 lat. Spadło również bezrobocie osób młodych: w 2013 r., kiedy było najwyższe, wynosiło 24\%, zaś w marcu 2018 r. - 15,6\%.

5 Konkluzje Rady w sprawie wytycznych budżetowych na 2019 r. (6315/18); rezolucja Parlamentu Europejskiego w sprawie ogólnych wytycznych dotyczących przygotowania budżetu na rok 2019 (2017/2286(BUD)). 
Budżet na rok 2019 w dalszym ciągu będzie oddziaływać na zwiększenie inwestycji i pobudzanie wzrostu gospodarczego, wspieranie zatrudnienia i tworzenie nowych miejsc pracy, wzmacnianie faktycznej spójności w UE i rolnictwa oraz wspieranie konkurencyjności. Jednocześnie uwzględniać będzie wymiar społeczny i środowiskowy, a w szczególności wspierać państwa członkowskie we wdrażaniu porozumienia paryskiego w wysiłkach na rzecz przeciwdziałania zmianom klimatu ${ }^{6}$. W budżecie przewidziano również nowe inicjatywy dotyczące wzrostu gospodarczego, który sprzyjać będzie włączeniu społecznemu, takie jak powołanie Europejskiego Urzędu ds. Pracy' nadal też położony zostanie nacisk na środki na rzecz młodzieży.

Budżet zapewni też środki na utworzenie Europejskiego Wspólnego Przedsięwzięcia w dziedzinie Obliczeń Wielkiej Skali poprzez m.in. wniesienie wkładu $\mathrm{z}$ instrumentu „Łącząc Europę”. Celem tego nowego podmiotu ma być promowanie najnowszych technologii obliczeń wielkiej skali oraz infrastruktury danych i wspieranie rozwoju technologii i jej zastosowania w wielu obszarach, $\mathrm{z}$ korzyścią dla naukowców, przemysłu i sektora publicznego ${ }^{8}$.

Poza tym w budżecie ujęto środki m.in. na potrzeby nowej Prokuratury Europejskiej, na Unijny Mechanizm Ochrony Ludności, na Europejski Program Rozwoju Przemysłu Obronnego, na Europejski Korpus Solidarności, na Instrument Pomocy dla Uchodźców w Turcji oraz na Program Wspierania Reform Strukturalnych 2.09.

Wieloletnie ramy finansowe, stanowiące pułap wydatkowy, zakładają na rok $2019^{10}$ :

- środki na płatności w kwocie 166,7 mld euro oraz

- środki na zobowiązania w wysokości 164,1 mld euro.

Przedłożony przez Komisję projekt budżetu UE na rok 2019 nieco odbiega od WRF, zakłada bowiem:

- dochody i środki na płatności w wysokości 148,7 mld euro ${ }^{11}$ oraz

6 Zgodnie z założeniem do 2020 r. 20\% budżetu ma być wykorzystane na przeciwdziałanie zmianom klimatu.

7 Https://ec.europa.eu/poland/news/europejski-urz\%C4\%85d-ds-pracy_pl.

8 Zob. COM(2018) 8 final.

9 Tabele obrazujące budżet ogólny UE na rok 2019 znajdują się w COM(2018) 600 final, s. 7, 208.

10 Dane liczbowe oparto na dostosowaniu technicznym ram finansowych na 2019 r. odpowiednio do zmian DNB, przyjętym przez Komisję w dniu 23 maja 2018 r., $\operatorname{COM}(2018) 282$ final.

11 Planowany poziom dochodów odpowiada poziomowi środków na płatności z uwagi na obowiązującą zasadę równowagi budżetu unijnego. 
- środki na zobowiązania (ang. commitment appropriations) w kwocie 165,6 mld euro.

Oznacza to, że środki na płatności będą poniżej limitu przyjętego w WRF o 18 mld euro, natomiast na zobowiązania niższe o 1,5 mld euro.

Niemniej na rok przyszły planuje się także wyższy margines środków na płatności (wyniesie 19,3 mld euro wobec ok. 11 mld euro w 2018 r.). Margines środków na zobowiązania będzie natomiast nieznacznie niższy (wyniesie 1,1 mld euro wobec 1,3 mld euro w 2018 r.).

Budżet ten uwzględnienia instrument elastyczności, na który zaplanowano więcej środków niż w 2018 r., jak również inne instrumenty szczególne obejmujące rezerwę na pomoc nadzwyczajną (EAR), Europejski Fundusz Dostosowania do Globalizacji (EFG) i Fundusz Solidarności Unii Europejskiej (FSUE), na które łącznie przewidziano mniej środków niż w roku $2018^{12}$.

Zaplanowane w budżecie środki na zobowiązania będą wyższe niż w roku 2018 o 4,9 mld euro (tj. 3,1\%), a środki na płatności wyższe o 3,9 mld euro (tj. o $2,7 \%)^{13}$. Nie są to wzrosty duże, niemniej w odniesieniu do płatności należy przypomnieć, że w uzasadnieniu projektu wskazuje się, iż opóźnienia $\mathrm{w}$ realizacji programów polityki spójności na lata 2014-2020 dawały powody do niepokoju w 2016 r. i przez większość 2017 r. Obecnie wydaje się, że trend ten odwrócił się, bowiem liczba składanych wniosków o płatności wzrosła gwałtownie w listopadzie i grudniu 2017 r., pojawiły się też oznaki, że nowe programy spójności wreszcie osiągnęły pełną zdolność operacyjną. Aby jednak uniknąć nagromadzenia zaległości w płatnościach na kolejne WRF, należy, zdaniem Komisji, zachować proaktywne podejście na wszystkich szczeblach. W tym względzie pomocna powinna się okazać uzgodniona w grudniu 2017 r. zmiana rozporządzenia finansowego; uproszczono przepisy, zwiększono przejrzystość oraz wprowadzono skuteczniejsze kontrole, po to aby środki publiczne były efektywniej wykorzystywane.

Komisja wskazuje również, że realizacja płatności w poprzednich WRF dobiega końca, a poziom płatności założony w budżecie na 2018 r. jest ambitny, dlatego też należy oczekiwać umiarkowanego wzrostu płatności w 2019 r. w porównaniu z $2018 \mathrm{r}$.

12 W ramach instrumentu elastyczności zaplanowano w 2019 r. w środkach na zobowiązania prawie 1 mld euro i w środkach na płatności 0,9 mld euro, tj. więcej niż w $2018 \mathrm{r}$. odpowiednio o 15,3\% i 32,6\%. Jednocześnie na inne instrumenty szczególne przewidziano na 2019 r. w środkach na zobowiązania prawie 0,6 mld euro i w środkach na płatności 0,4 mld euro, tj. mniej niż w 2018 r. odpowiednio o 13,1\% i 20,4\%.

13 Po uwzględnieniu korekt nr 1-3 dotyczących tegorocznego budżetu. Środki na zobowiązania stanowić będą w 2019 r. 1,0\% DNB, na płatności zaś 0,9\% DNB. 
Planowane zwiększenie dochodów budżetu unijnego o 3,9 mld euro wynikać będzie m.in. z istotnie wyższych wpłat z zasobów własnych opartych na dochodzie narodowym brutto - DNB (o 5,3 mld euro) oraz niższych wpłat z ceł i opłat wyrównawczych od cukru (o 1,4 mld euro). Towarzyszyć temu będzie zmniejszenie w takich m.in. niewielkich pozycjach jak: „nadwyżki, salda i dostosowania” oraz „dochody z działalności administracyjnej instytucji”.

W strukturze planowanych dochodów zasoby własne stanowić już będą 98,7\% dochodów ogółem, dochody zaś pochodzące od osób pracujących w instytucjach i innych organach UE - 1,1\%, natomiast wszystkie pozostałe dochody $0,2 \%$ (zob. tabela 1 ).

Tabela 1. Dochody w mln euro

\begin{tabular}{|c|c|c|c|c|c|c|}
\hline Poz. & Wyszczególnienie & $\begin{array}{c}\text { Budżet } \\
2018 *\end{array}$ & $\begin{array}{l}\text { Budżet } \\
2019\end{array}$ & $\begin{array}{l}\text { zmiana } \\
\text { proc. }\end{array}$ & $\begin{array}{c}\text { Struktura } \\
2018 \\
\text { w } \%\end{array}$ & $\begin{array}{l}\text { Struktura } \\
2019 \\
\text { w \% }\end{array}$ \\
\hline \multirow[t]{4}{*}{1} & Zasoby własne & 142374,4 & 146771,6 & 3,1 & 98,3 & 98,7 \\
\hline & $\begin{array}{l}\text { - kwota netto ceł i opłat wyrównawczych } \\
\text { od cukru }\end{array}$ & 22844,0 & 21471,2 & $-6,0$ & 15,8 & 14,4 \\
\hline & - zasoby własne oparte na VAT & 17249,6 & 17738,7 & 2,8 & 11,9 & 11,9 \\
\hline & $\begin{array}{l}\text { - różnica pozostająca do sfinansowania } \\
\text { z zasobów dodatkowych (zasoby włas- } \\
\text { ne oparte na DNB) }\end{array}$ & 102280,9 & 107561,8 & 5,2 & 70,6 & 72,3 \\
\hline 2 & Nadwyżki, salda i dostosowania & 555,5 & & $\times$ & 0,4 & $\times$ \\
\hline 3 & $\begin{array}{l}\text { Dochody pochodzące od osób pracują- } \\
\text { cych w instytucjach i innych organach Unii }\end{array}$ & 1547,4 & 1616,0 & 4,4 & 1,1 & 1,1 \\
\hline 4 & $\begin{array}{l}\text { Dochody z działalności administracyjnej } \\
\text { instytucji }\end{array}$ & 45,1 & 25,1 & $-44,4$ & 0,0 & 0,0 \\
\hline 5 & $\begin{array}{l}\text { Wkłady i zwroty związane z realizacją } \\
\text { porozumień i programów unijnych }\end{array}$ & 110,0 & 130,0 & 18,2 & 0,1 & 0,1 \\
\hline 6 & Odsetki od zaległych płatności i grzywny & 115,0 & 115,0 & 0,0 & 0,1 & 0,1 \\
\hline 7 & Operacje zaciągania i udzielania pożyczek & 6,2 & 2,8 & $\times$ & 0,0 & $\times$ \\
\hline \multirow[t]{2}{*}{8} & Dochody różne & 25,0 & 15,0 & $-40,0$ & 0,0 & 0,0 \\
\hline & Dochody ogółem & 144778,6 & 148675,5 & 2,7 & 100,0 & 100,0 \\
\hline
\end{tabular}

* Z uwzględnieniem budżetu korygującego nr 1 i projektów budżetów korygujących nr 2 i 3.

Źródło: COM(2018) 600 final, s. 2 i 8 ogólnego zestawienia dochodów.

Dominujący udział w wydatkach ogółem budżetu w 2019 r. (wg płatności) będą miały:

- dział 1 - Inteligentny wzrost gospodarczy sprzyjający włączeniu społecznemu 45,4\%. Dział ten obejmuje wydatki na:

- konkurencyjność na rzecz wzrostu gospodarczego i zatrudnienia (dział 1a); w jego ramach proponuje się wydatkowanie kwoty 20,5 mld euro (będzie to o 1,8\% więcej niż w budżecie roku 2018),

- spójność gospodarczą, społeczną i terytorialną (dział 1b); w jego ramach proponuje się wydatkowanie kwoty 47,1 mld euro (będzie to o $1,1 \%$ więcej niż w budżecie roku 2018), 
- dział 2 - Zrównoważony wzrost gospodarczy: zasoby naturalne - 38,9\% udział w wydatkach. W dziale tym zaplanowano wydatkowanie kwoty 57,8 mld euro, tj. o 3\% więcej niż w 2018 r. W przypadku Europejskiego Funduszu Rolniczego Gwarancji - wydatki związane z rynkiem i płatnościami bezpośrednimi będą wyższe niż w 2018 r. o 0,8\%.

Pozostałe działy budżetu charakteryzować się będą znacznie niższym udziałem w wydatkach budżetu UE:

- dział 3 - Bezpieczeństwo i obywatelstwo - 2,3\% udział w wydatkach; w tym dziale zaplanowano prawie 3,5 mld euro, a więc więcej niż w 2018 r. o 17\%,

- dział 4 - Globalny wymiar Europy - 6,4\% udział w wydatkach; w tym dziale zaplanowano 9,5 mld euro, a więc więcej niż w 2018 r. o 6,8\%,

- dział 5 - Administracja - 6,7\% udział w wydatkach, co odpowiada zaplanowaniu kwoty wynoszącej prawie 10 mld euro, tj. wyższej niż w 2018 r. o 3\%.

Tabela 2. Środki na płatności (PA) w mln euro ceny bieżące

\begin{tabular}{|c|c|c|c|c|c|}
\hline \multirow[b]{2}{*}{ Wyszczególnienie } & \multirow{2}{*}{$\begin{array}{l}\text { Budżet } \\
\text { 2018* }\end{array}$} & \multirow{2}{*}{$\begin{array}{l}\text { Budżet } \\
2019\end{array}$} & \multirow{2}{*}{$\begin{array}{c}\text { zmiana } \\
\text { w pkt. proc. }\end{array}$} & \multicolumn{2}{|c|}{ struktura wydatków } \\
\hline & & & & $\begin{array}{l}2018 \text { r. } \\
\text { w \% }\end{array}$ & $\begin{array}{l}2019 \text { r. } \\
\text { w \% }\end{array}$ \\
\hline $\begin{array}{l}\text { 1. Inteligentny wzrost gospodarczy sprzyja- } \\
\text { jący włączeniu społecznemu }\end{array}$ & 66624,5 & 67517,9 & 1,3 & 46,0 & 45,4 \\
\hline $\begin{array}{l}\text { 1a - Konkurencyjność na rzecz wzrostu } \\
\text { gospodarczego i zatrudnienia }\end{array}$ & 20097,2 & 20467,2 & 1,8 & 13,9 & 13,8 \\
\hline $\begin{array}{l}\text { 1b - Spójność gospodarcza, społeczna } \\
\text { i terytorialna }\end{array}$ & 46527,3 & 47050,8 & 1,1 & 32,1 & 31,6 \\
\hline $\begin{array}{l}\text { 2. Zrównoważony wzrost gospodarczy: } \\
\text { zasoby naturalne }\end{array}$ & 56083,8 & 57790,4 & 3,0 & 38,7 & 38,9 \\
\hline $\begin{array}{l}\text { w tym: Europejski Fundusz Rolniczy } \\
\text { Gwarancji (EFRG) - wydatki związane } \\
\text { z rynkiem i płatności bezpośrednie }\end{array}$ & 43188,7 & 43537,9 & 0,8 & 29,8 & 29,3 \\
\hline 3. Bezpieczeństwo i obywatelstwo & 2980,7 & 3486,4 & 17,0 & 2,1 & 2,3 \\
\hline 4. Globalny wymiar Europy & 8906,1 & 9508,4 & 6,8 & 6,2 & 6,4 \\
\hline 5. Administracja & 9666,3 & 9960,9 & 3,0 & 6,7 & 6,7 \\
\hline w tym: wydatki administracyjne instytucji & 7580,7 & 7759,3 & 2,4 & 5,2 & 5,2 \\
\hline 6. Rezerwa ujemna & $-70,4$ & 0,0 & & 0,0 & 0,0 \\
\hline Wydatki ogółem poz. 1-6 & 144261,4 & 148264,0 & 2,8 & 99,6 & 99,7 \\
\hline Inne specjalne instrumenty & 517,2 & 411,5 & $-20,4$ & 0,4 & 0,3 \\
\hline Suma całkowita & 144778,6 & 148675,5 & 2,7 & 100,0 & 100,0 \\
\hline Margines & 10982,0 & 19344,7 & $176,1 \%$ & & \\
\hline Środki jako \% DNB & $0,92 \%$ & $0,90 \%$ & & & \\
\hline
\end{tabular}

* Z uwzględnieniem budżetu korygującego nr 1 i projektów budżetów korygujących nr 2 i 3.

Źródło: $\operatorname{COM(2018)600~final,~s.~7-9.~}$

Jednocześnie zmniejszą się wydatki w ramach innych specjalnych instrumentów (o 20,4\%) i wyniosą one 0,4 mld euro.

Większy będzie także dostępny margines środków, który zaplanowano na kwotę 19,3 mld euro, wobec prawie 11 mld euro w 2018 r.

Szczegółowa analiza planowanych wydatków (wg płatności) wskazuje, że: 
- W dziale 1a - Konkurencyjność na rzecz wzrostu i zatrudnienia, dotyczącym finansowania polityk przyczyniających się do tworzenia zrównoważonej gospodarki o wysokim poziomie zatrudnienia, produktywności i spójności społecznej oraz łączącym wiele głównych inicjatyw strategii „Europa 2020”, planowane wydatki w porównaniu z 2018 r. zwiększą się o prawie 0,4 mld euro.

Wzrost ten spowodowany jest głównie potrzebami związanymi z:

- dużymi projektami infrastrukturalnymi (tj. europejskim systemem nawigacji satelitarnej i europejskim programem monitorowania Ziemi) - wzrost o 0,3 mld euro, tj. o 18,2\%,

- programem „Kształcenie, Szkolenie i Sport” (Erasmus+) ${ }^{14}$ - wzrost o prawie 0,3 mld euro, tj. o $12,5 \%$,

- instrumentem „Łącząc Europę"15 - wzrost o prawie 0,2 mld euro, tj. o 11,7\%,

- Europejskim Programem Rozwoju Przemysłu Obronnego (EDIDP) - na który przewidziano prawie 0,15 mld euro,

- wydatkami agencji zdecentralizowanych - wzrost o 0,1 mld euro, tj. o 27,9\%,

- wydatkami na wspólne ramy strategiczne (WRS) - badania i rozwój - wzrost o 0,1 mld euro, tj. o $0,8 \%$,

- wydatkami na Europejski Korpus Solidarności (ESC) - wzrost o 0,05 mld euro, tj. o $65,1 \%$.

Jednocześnie w odniesieniu do Europejskiego Funduszu na rzecz Inwestycji Strategicznych nastąpi spadek wydatków na kwotę prawie 0,7 mld euro, tj. o 35,9\%. Poza tym istotne zmniejszenie wydatków w porównaniu z 2018 r. dotyczyć będzie także projektów $\mathrm{w}$ dziedzinie energetyki wspomagających naprawę gospodarczą (o 0,15 mld euro, tj. o $71 \%$ ).

- W dziale $1 \mathrm{~b}$ - Spójność gospodarcza, społeczna i terytorialna wydatki zwiększą się o 0,5 mld euro w porównaniu z 2018 r.

Wzrost ten wynika głównie ze zwiększenia płatności na konwergencję regionalną dla regionów słabiej rozwiniętych (o 0,65 mld euro, tj. o 2,8\%), na regiony w okresie przejściowym (o prawie 0,3 mld euro, tj. o 8,2\%), na instrument „Łącząc Europę" - wkład Funduszu Spójności (wzrost o 0,2 mld euro, tj. o 36,1\%).

Jednocześnie płatności dla Funduszu Spójności spadną o 0,75 mld euro, tj. o 8,9\%.

14 Obejmuje on programy sektorowe odpowiadające poszczególnym sektorom kształcenia i szkolenia, tj. edukację, szkolenia młodzieży i sportu oraz wymiany studentów.

15 Program ten wspiera realizację projektów mających na celu rozwój, budowę lub modernizację nowej i istniejącej infrastruktury w dziedzinie transportu, energetyki i telekomunikacji [CEF - Energy, CEF - Transport (stanowiący największą część programu), CEF - Information and Communications Technology (ICT)]; przyczynia się do osiągnięcia inteligentnego i zrównoważonego wzrostu sprzyjającego włączeniu społecznemu poprzez tworzenie nowoczesnych i wysoko wydajnych sieci transeuropejskich. 
- W dziale 2 - Zrównoważony wzrost gospodarczy: zasoby naturalne wydatki wzrosną o 1,7 mld euro, tj. o 3\% w porównaniu z rokiem 2018.

Z ogólnej puli środków w tym dziale na realizację Europejskiego Funduszu Rolniczego Gwarancji (EFRG) - dopłaty bezpośrednie i działania rynkowe - zostanie przeznaczona kwota 43,5 mld euro, tj. wyższa o $0,8 \%$ (0,3 mld euro) w porównaniu z rokiem 2018.

Na Europejski Fundusz Rolny na rzecz Rozwoju Obszarów Wiejskich (EFRROW) przewiduje się kwotę 13,1 mld euro, tj. większą o 10,8\% (1,3 mld euro).

Wydatki Europejskiego Funduszu Morskiego i Rybackiego (EFMR), umowy w sprawie zrównoważonych połowów (SFPA) oraz składki na regionalne organizacje ds. zarządzania rybołówstwem (RFMO) i inne organizacje międzynarodowe mają wynieść 0,7 mld euro, tj. wzrosną o blisko $60 \mathrm{mln}$ euro (9,2\%).

Wydatki na program działań na rzecz środowiska i klimatu (LIFE+) ukształtują się na poziomie $0,3 \mathrm{mld}$ euro (wzrost o 25,5 mln euro, tj. o 8,1\%).

- W dziale 3 - Bezpieczeństwo $i$ obywatelstwo wydatki wzrosną o 0,5 mld euro, tj. o 17\% w porównaniu z rokiem 2018.

Wzrost środków dotyczy przede wszystkim:

- Funduszu Azylu, Migracji i Integracji - o prawie 0,4 mld euro, czyli o 60,3\%,

- Funduszu Bezpieczeństwa Wewnętrznego - o blisko 0,2 mld euro, czyli o $37,9 \%$,

- unijnego mechanizmu ochrony ludności, na który zaplanowano 81,7 mln euro, tj. więcej o 0,05 mld euro (o 138,3\%).

Jednocześnie nastąpi zmniejszenie płatności w odniesieniu do instrumentu na rzecz wsparcia w sytuacjach nadzwyczajnych na terenie Unii (o 0,15 mld euro, tj. o 68,5\%). Zmniejszenia dotyczyć będą także projektów pilotażowych i działań przygotowawczych, systemów informatycznych i sprawiedliwości.

- W dziale 4 - Globalny wymiar Europy ${ }^{16}$ wydatki zwiększą się o 0,6 mld euro, tj. 6,8\% w porównaniu $\mathrm{z}$ rokiem 2018.

Większość, bo aż 70\% wydatków tego działu, stanowią trzy główne programy finansowania działań zewnętrznych (wsparcie finansowe krajów trzecich): Instrument Pomocy Przedakcesyjnej (IPA II), Europejski Instrument Sąsiedztwa (ENI) oraz Instrument Finansowania Współpracy na rzecz Rozwoju (DCI), natomiast pomoc humanitarna - 16,8\% wydatków działu. Finansowanie najważniejszych działań zaplanowanych na 2019 r. obejmuje:

16 Dział ten obejmuje również Instrument na rzecz Przyczyniania się do Stabilności i Pokoju (IcSP). W dziale tym uwzględnia się również środki na pomoc humanitarną, wspólną politykę zagraniczną i bezpieczeństwa (CFSP) oraz pomoc makrofinansową dla państw trzecich i fundusz gwarancyjny dla działań zewnętrznych. 
- IPA II - 1,8 mld euro (wzrost o 0,3 mld euro, czyli o $23,8 \%$ ),

- DCI - 2,8 mld euro (wzrost o 61,7 mln euro, czyli o 2,3\%),

- ENI - 2,1 mld euro (spadek o 0,2 mld euro, czyli o 9,6\%),

- Instrument Partnerstwa - 99,6 mln euro (spadek o 1,1 mln euro, czyli o 1,1\%),

- IcSP - 321,3 mln euro (spadek o prawie 4 mln euro, czyli o 1,2\%),

- pomoc humanitarna - 1,6 mld euro (wzrost o 0,5 mld euro, czyli o 46,4\%).

W projekcie budżetu mniejsze w stosunku do 2018 r. będą środki na płatności w odniesieniu m.in. do: Funduszu Gwarancyjnego dla działań zewnętrznych (GF) (o 89,6 mln euro, tj. o 65\%), Europejskiego Instrumentu na rzecz Wspierania Demokracji i Praw Człowieka (EIDHR) (o $10 \mathrm{mln}$ euro, tj. o 5,9\%), projektów pilotażowych i działań przygotowawczych (o 9,4 mln euro, tj. o 65,6\%).

- W dziale 5 - Administracja wydatki zwiększą się prawie o 0,3 mld euro, tj. o $3 \% \mathrm{w}$ porównaniu z rokiem 2018.

Na Komisję przypada 36,5\% całkowitych wydatków działu 5, a na pozostałe instytucje $-41,4 \%$, na emerytury zaś przypada $20,2 \%$, na szkoły europejskie $1,9 \%$.

Wydatki administracyjne Komisji będą wyższe o $2 \%$ w porównaniu z rokiem 2018, a wydatki innych instytucji ujmowanych łącznie będą większe o 2,6\%. W najwyższym stopniu - bo aż o 6,2\% wzrosną wydatki na emerytury pracownicze. Wydatki na szkoły europejskie będą niższe o $0,4 \%$.

Jeśli chodzi o inne instytucje, to wzrost wydatków jest zróżnicowany od 0,8\% w odniesieniu do Europejskiego Trybunału Obrachunkowego do 16\% w przypadku Europejskiego Inspektora Ochrony Danych Osobowych. Tak wysoki wzrost (z odpowiadającą mu kwotą - 2,3 mln euro) wynika prawie całkowicie z nowych obowiązków Sekretariatu Europejskiej Rady Ochrony Danych oraz dodatkowych potrzeb związanych z nowymi przepisami w zakresie ochrony danych $w$ instytucjach UE, a także monitorowania i zapewnienia przestrzegania przepisów o ochronie danych przez agencje dawnego trzeciego filara.

Jednocześnie Komisja przypomniała, że w 2018 r. możliwa była ocena realizacji celu określonego w 2013 r., który zakładał ograniczenie ogólnej liczby personelu $\mathrm{w}$ agencjach o $5 \%{ }^{17}$. $\mathrm{Z}$ oceny tej wynikało, że redukcja personelu $\mathrm{w}$ większości agencji została zasadniczo przeprowadzona zgodnie z planem, na jej ostateczne wyniki duży wpływ miały jednak wyzwania związane z migracją i bezpieczeństwem, jakie pojawily się w ostatnich latach. Skutki tych wyzwań są nadal odczuwalne i będą wymagały uwzględnienia również w 2019 r. Należy też pamiętać, że w projekcie budżetu na 2019 r. przewidziano rezerwę na ustanowienie Europejskiego Urzędu ds. Pracy oraz Prokuratury Europejskiej, jak również zaproponowano wzmocnienie agencji zajmujących się kwestiami migracji i bezpieczeństwa oraz organów nadzoru finansowego - $\mathrm{z}$ uwagi na ich nowe zadania.

17 Swój cel w zakresie ograniczenia zatrudnienia o 5\% Komisja zrealizowała wcześniej. 
Przy opracowywaniu projektu budżetu na 2019 r. Komisja zachęciła wszystkie instytucje i organy UE do tego, by w trakcie opracowywania swoich preliminarzy zastosowały rygorystyczne podejście w odniesieniu do liczby pracowników i wydatków administracyjnych. Niemniej Komisja stwierdziła, że ma świadomość, iż zamrożenie kosztów w ujęciu nominalnym przez osiem lat z rządu staje się coraz trudniejsze.

Tabela 3. Wydatki administracyjne (kwoty w mln euro, w cenach bieżących)

\begin{tabular}{|c|c|c|c|c|c|}
\hline & \multirow[b]{2}{*}{$\begin{array}{c}\text { Budżet } \\
2018\end{array}$} & \multirow{2}{*}{$\begin{array}{c}\text { Projekt } \\
\text { budżetu } \\
\text { UE na rok } \\
2019\end{array}$} & \multirow[b]{2}{*}{$\begin{array}{c}\text { Udział } \\
\text { w \% }\end{array}$} & \multicolumn{2}{|c|}{ Różnica } \\
\hline & & & & $\begin{array}{l}2019- \\
2018\end{array}$ & $\begin{array}{c}2019 / \\
2018 \\
\text { w \% }\end{array}$ \\
\hline Emerytury i szkoły europejskie & 2085,6 & 2201,6 & 22,1 & 116,0 & 5,6 \\
\hline Emerytury & 1892,8 & 2009,5 & 20,2 & 116,7 & 6,2 \\
\hline Emerytury pracownicze & 1867,2 & 1983,0 & 19,9 & 115,9 & 6,2 \\
\hline Emerytury dla byłych członków & 25,7 & 26,5 & 0,3 & 0,8 & 3,3 \\
\hline Szkoły europejskie & 192,8 & 192,1 & 1,9 & $-0,7$ & $-0,4$ \\
\hline Wydatki administracyjne instytucji & 7579,9 & 7755,3 & 77,9 & 175,4 & 2,3 \\
\hline Komisja Europejska & 3565,5 & 3637,2 & 36,5 & 71,7 & 2,0 \\
\hline Inne instytucje & 4014,4 & 4118,1 & 41,4 & 103,7 & 2,6 \\
\hline Parlament Europejski & 1950,2 & 1998,5 & 20,1 & 48,3 & 2,5 \\
\hline Rada Europejska i Rada UE & 572,9 & 583,0 & 5,9 & 10,1 & 1,8 \\
\hline Europejski Trybunał Sprawiedliwości & 410,0 & 430,0 & 4,3 & 20,0 & 4,9 \\
\hline Europejski Trybunał Obrachunkowy & 146,0 & 147,3 & 1,5 & 1,2 & 0,8 \\
\hline Europejski Komitet Społeczno-Ekonomiczny & 135,6 & 138,8 & 1,4 & 3,1 & 2,3 \\
\hline Komitet Regionów & 96,1 & 98,9 & 1,0 & 2,8 & 2,9 \\
\hline Rzecznik Praw Obywatelskich & 10,6 & 11,3 & 0,1 & 0,7 & 6,4 \\
\hline Europejski Inspektor Ochrony Danych Osobowych & 14,4 & 16,8 & 0,2 & 2,3 & 16,0 \\
\hline Europejska Służba Działań Zewnętrznych & 678,5 & 693,7 & 7,0 & 15,2 & 2,2 \\
\hline Razem & 9665,5 & 9956,9 & 100,0 & 291,4 & 3,0 \\
\hline Limit & 10346,0 & 10786,0 & & & \\
\hline Margines & 362,5 & 575,2 & & & \\
\hline
\end{tabular}

Źródło: COM(2018) 600 final, s. 65.

\section{- Geneza dokumentu UE}

Elementy procedury budżetowej ustala art. 310-316 Traktatu o funkcjonowaniu Unii Europejskiej (TFUE). Głównymi instytucjami UE zaangażowanymi w jego przyjmowanie są: Komisja, Rada i Parlament Europejski.

Roczny budżet UE powinien być zgodny z wieloletnimi ramami finansowymi (ustalanymi na okres co najmniej 5 lat), które mają na celu zapewnienie dokonywania wydatków UE w sposób usystematyzowany i w granicach jej zasobów własnych. Ramy te określają kwoty rocznych pułapów środków na zobowiązania, z podziałem na kategorie wydatków oraz roczny pułap środków na płatności.

Należy wskazać, że z przedłożonym projektem budżetu powiązanych jest wiele dokumentów, w tym:

- komunikat Komisji do Rady i Parlamentu Europejskiego: Dostosowanie techniczne ram finansowych na 2019 r. do zmian DNB (ESA 2010) (art. 6 rozpo- 
rządzenia Rady nr 1311/2013 określającego wieloletnie ramy finansowe na lata 2014-2020), $\operatorname{COM(2018)~} 282$ final,

- wniosek dotyczący decyzji Parlamentu Europejskiego i Rady w sprawie uruchomienia Funduszu Solidarności Unii Europejskiej w celu zapewnienia środków na wypłatę zaliczek w budżecie ogólnym Unii na 2019 r., COM(2018) 281 final,

- wniosek dotyczący decyzji Parlamentu Europejskiego i Rady w sprawie uruchomienia instrumentu elastyczności na sfinansowanie natychmiastowych środków budżetowych służących do rozwiązywania bieżących problemów wynikających z migracji, napływu uchodźców i zagrożeń bezpieczeństwa oraz rozszerzenia programu wspierania reform strukturalnych, COM(2018) 280 final.

\section{- Informacja o stanie prawa obowiązującego w Polsce w materii objętej treścią dokumentu UE}

Przyjęcie budżetu ogólnego UE nie ma wpływu na polskie prawodawstwo (dokument nie wymaga transpozycji do polskiego porządku prawnego). Prawo polskie nie reguluje zasad i procedur uchwalania budżetu UE.

\section{Ocena dokumentu UE}

\section{- Ocena skutków finansowych dokumentu UE}

Ocena projektu budżetu na 2019 r. jest generalnie pozytywna, bo jest to budżet nieco większy niż budżet roku bieżącego, który finansować będzie w zasadzie na dotychczasowym poziomie wydatki działu la - Konkurencyjność na rzecz wzrostu gospodarczego i zatrudnienia i działu 1b - Spójność gospodarcza, społeczna i terytorialna (aczkolwiek kwestionowane mogą być szczegółowe wydatki zaplanowane w tych działach, np. zmniejszenie płatności na konkurencyjność przedsiębiorstw oraz małych i średnich przedsiębiorstw czy wzrost wydatków na regiony w okresie przejściowym i na regiony najbardziej oddalone i słabo zaludnione). Budżet ten zapewni też wzrost wydatków działu 2 - Zrównoważony wzrost gospodarczy: zasoby naturalne, w tym zwłaszcza w odniesieniu do funduszy rolniczych, umożliwi większe płatności związane $\mathrm{z}$ funduszami morskimi i rybackimi oraz z działaniami na rzecz środowiska i klimatu. Poza tym przewiduje on istotne zwiększenie wydatków na bezpieczeństwo i reagowanie na ostatnie wyzwania związane z migracją.

Niemniej powstają obawy, czy zaplanowany poziom płatności będzie wystarczający. Rząd z niepokojem zauważa, że proponowany w projekcie budżetu poziom płatności jest na tym samym poziomie, co płatności w wykonanym budżecie za rok 2013 - co przy stosowanym w WRF rocznym deflatorze inflacyjnym (2\%) oznacza spadek budżetu o 12,6 pkt proc. Ponadto może on nie pozwolić sprostać spodziewanej już w roku 2018 kumulacji płatności w ramach polityki 
spójności oraz zwiększonemu zapotrzebowaniu na płatności na rzecz migracji i innych nowych wyzwań.

Niepokój może także budzić stały wzrost wydatków o charakterze administracyjnym. Są to wydatki ujęte w dziale 5 - Administracja oraz w innych działach, w których przewidziane są wydatki na agencje zdecentralizowane. Środki na płatności w odniesieniu do wydatków administracyjnych sięgają już ok. 7,7\% całkowitych wydatków. W tym kontekście można postawić pytanie dotyczące celowości powoływania ciągle nowych instytucji, które z czasem będą rozrastać się, mnożyć swoje zadania, a efekty ich działalności niekoniecznie będą satysfakcjonujące w odbiorze europejskiego podatnika.

Powstaje też pytanie, dlaczego wydatki np. Parlamentu Europejskiego, Rady Europejskiej i Rady UE, różnych komitetów rosną szybciej niż wydatki tak ważniej instytucji jak Europejski Trybunał Obrachunkowy.

Inne pytanie dotyczyć może tego, czy sprawiedliwe jest przeznaczanie coraz większych środków na emerytury z budżetu unijnego, skoro w wielu państwach UE, nawet tych bogatych, systemy emerytalne stoją przed ogromnymi wyzwaniami dotyczącymi m.in. tego, czy będą w stanie zapewnić wielu obywatelom (w tym dobrze wykształconym i o relatywnie długim stażu pracy) odpowiedni poziom emerytur.

Warto też dodać, że proponowane dalsze zwiększanie środków na zobowiązania (aczkolwiek niewielkie i uzasadnione) generować może w przyszłości potrzebę zwiększenia płatności, a także wzrostu składki do budżetu UE, która może ulec zwiększeniu po wyjściu Wielkiej Brytanii z UE.

Przyjęcie proponowanego projektu budżetu nie spowoduje skutków społecznych i gospodarczych w Polsce. Jeśli chodzi o skutki finansowe, to należy wskazać, że zaplanowana kwota dochodów i środków na płatności (148,7 mld euro) będzie sfinansowana w ramach składki do budżetu ogólnego UE przez wszystkie państwa członkowskie, zgodnie z ich procentowym udziałem w sumie zasobów własnych UE.

Polska wpłaci do budżetu UE środki w kwocie ok. 5 mld euro (stanowiącą ok. 3,4\% udziału we wpłatach wszystkich państw członkowskich z tytułu zasobów własnych ${ }^{18}$ ), tj. kwotę nieco wyższą od obecnie uiszczanej. Największej wpłaty dokonają Niemcy - 30,6 mld euro (20,8\% udział), Francja - 22,7 mld euro (15,4\% udział), Wielka Brytania - 17,6 mld euro (12,0\% udział), Włochy - 17,1 mld euro (11,6\% udział) i Hiszpania - 12,2 mld euro (8,3\% udział $)^{19}$.

Do tej pory Polska otrzymywała więcej środków z budżetu unijnego niż do niego wpłacała. Przykładowo w 2017 r. Polska otrzymała z tego budżetu 11,2 mld

Zob. t. I, Dochody ogótem, tab. 7, kol. 11, s. 7 i n.

19 Zob. ostatnia kolumna tabeli 1.A, $\operatorname{COM}(2018) 600$ final. Przytaczamy tu dane z kolumny 11 i 12, a nie z kolumn 9 i 10, ponieważ ta ostatnia kolumna uwzględnia wszystkie zasoby własne (tj. także tradycyjne zasoby własne netto) w kwocie 143 570,8 mln euro. 
euro, przy składce na poziomie ok. 3,6 mld euro, co dawało dodatnią pozycję netto w wysokości ok. 7,6 mld euro.

W roku 2019, wobec osiągnięcia poziomu 95\% wydatkowania środków z okresu programowania 2007-2013 w ramach polityki spójności (fundusze strukturalne oraz Fundusz Spójności), płatności pośrednie dla Polski z tego tytułu będą ograniczone. Pozostałe 5\% środków będzie wypłacone po sprawdzeniu przez Komisję Europejską, czy nie pojawiają się błędy w rozliczeniach. Zgodnie z informacjami przekazanymi przez Komisję większość płatności z tytułu wymienionych 5\% nastąpi najprawdopodobniej w 2018 r., a mniejsza część z tychże $5 \%$ zostanie przekazana w $2019 \mathrm{r}$.

\section{- Ocena zgodności dokumentu UE z zasadą pomocniczości}

Dokument nie podlega ocenie co do zgodności z zasadą pomocniczości w trybie protokołu nr 2.

\section{- Ustosunkowanie się do projektu stanowiska RP}

Przedstawiony przez Radę Ministrów projekt stanowiska RP nie budzi zastrzeżeń. W pełni zaakceptować należy zapowiedź rządu, że jego stanowisko w trakcie prac nad budżetem UE na rok 2019 będzie ukierunkowane na zapewnienie niezbędnych środków finansowych na spłacenie zobowiązań wcześniej zaciągniętych przez państwa członkowskie w imieniu budżetu UE (w szczególności dotyczy to polityki spójności oraz rozwoju obszarów wiejskich, które są bardzo istotnymi instrumentami inwestycyjnymi w UE).

Pozytywnie należy ocenić konsekwentne stanowisko rządu odnośnie do tego, że zasadne jest jasne uregulowanie $\mathrm{w}$ przyszłości płatności od instrumentów specjalnych ( $\mathrm{tj}$. ujmowania ich poza WRF) oraz stanowisko w odniesieniu do kwestii kryzysu migracyjnego i wydatków administracyjnych. Zgodzić się także można $\mathrm{z}$ tym, że z powodów prawnych i proceduralnych elementy projektu budżetu UE na rok 2019 powiązane z niezakończonymi procesami legislacyjnymi (m.in. Europejski Urząd ds. Pracy, Unijny Mechanizm Ochrony Ludności, Europejski Program Rozwoju Przemysłu Obronnego, Europejski Korpus Solidarności, Instrument Pomocy dla Uchodźców w Turcji, Program Wspierania Reform Strukturalnych 2.0) powinny zostać usunięte z projektu lub co najmniej odpowiednio zaznaczone (np. pozostawione w rezerwach budżetowych).

\section{Opinia prawna}

\section{Podstawa prawna dokumentu UE}

Podstawą prawną przyjęcia projektu budżetu ogólnego UE jest art. 314 TFUE. W przepisie tym ustanowiona została specjalna procedura ustawodawcza, według której Parlament Europejski i Rada ustanawiają roczny budżet UE. Zgod- 
nie $\mathrm{z}$ tą procedurą projekt budżetu, obejmujący prognozę dochodów i wydatków, przedstawiany jest Parlamentowi Europejskiemu i Radzie nie później niż 1 września roku poprzedzającego rok, w którym budżet ma być wykonywany. Rada obowiązana jest przyjąć stanowisko w sprawie projektu budżetu i przekazać je Parlamentowi Europejskiemu nie później niż 1 października tego roku. W ramach tej procedury, w przypadku zgłoszenia przez Parlament Europejski poprawek do projektu, może zostać powołany komitet pojednawczy, składający się z przedstawicieli Parlamentu i Rady. Podstawa prawna przyjęcia budżetu przewiduje procedurę ustawodawczą. Opiniowany projekt dotyczy działań prawodawczych w obszarze należącym do kompetencji UE, które wykonywane są wspólnie przez Parlament Europejski i Radę. Przedłożony projekt jest projektem aktu ustawodawczego. Wybór procedury i zastosowanego środka nie nasuwa - w świetle brzmienia art. 314 TFUE - wątpliwości. Projekt nie podlega ocenie parlamentów narodowych pod względem zgodności z zasadą pomocniczości w trybie określonym w protokole nr 2, ponieważ państwa członkowskie Unii Europejskiej nie dysponują kompetencją do stanowienia budżetu Unii Europejskiej.

\section{Skutki prawne}

Przyjęcie budżetu ogólnego UE nie będzie się wiązało z koniecznością dokonania zmian implementacyjnych w ustawodawstwie polskim. Projekt budżetu nie budzi wątpliwości legislacyjnych.

\section{Kwestie proceduralne}

\section{- Tryb stanowienia budżetu}

Projekt budżetu, zgodnie ze wskazaną podstawą prawną, powinien być przyjęty w specjalnej procedurze ustawodawczej. Rada stanowi większością kwalifikowaną. Projekt został przyjęty przez Komisję 21 czerwca 2018 r. Tego samego dnia został przekazany Parlamentowi Europejskiemu i Radzie. Obecnie stanowi przedmiot prac obu tych instytucji.

\section{- Działania Komisji ds. Unii Europejskiej}

Rada Ministrów przekazała Sejmowi projekt stanowiska RP na temat projektu budżetu 6 lipca 2018 r., zachowując tym samym 14-dniowy termin, który został określony w art. 7 ust. 1 ustawy o współpracy Rady Ministrów z Sejmem i Senatem w sprawach związanych z członkostwem RP w Unii Europejskiej. Zgodnie $\mathrm{z}$ art. 7 ust. 4 ustawy Komisja ds. UE może wyrazić opinię o projekcie aktu UE w terminie 49 dni od dnia przekazania Sejmowi tego aktu. Termin na wyrażenie opinii przez Komisję ds. UE upływa 12 sierpnia 2018 r. 


\section{Konkluzje}

Ocena projektu budżetu na 2019 r. jest generalnie pozytywna, aczkolwiek nie pozbawiona elementów krytycznych, w tym zwłaszcza w odniesieniu do wydatków administracyjnych i poziomu środków na płatności.

Przedstawiony przez Radę Ministrów projekt stanowiska RP nie budzi zastrzeżeń. 

2

OPINIE BAS

C

OPINIE LEGISLACYJNE 



\title{
Odpowiedzialność karna za przestępstwa z art. 55a ust. 1-2 oraz kontratyp z art. 55a ust. 3 ustawy o Instytucie Pamięci Narodowej - Komisji Ścigania Zbrodni przeciwko Narodowi Polskiemu ${ }^{1}$
}

\begin{abstract}
Criminal Liability referred to in article 55a paragraphs 1-2 and its exclusion ("kontratyp") article 55a paragraphs 3 of the Act on the Institute of National Remembrance Commission for the Prosecution of Crimes against the Polish Nation: The provisions of the Act, which are the subject of questions presented in the order to prepare the expert opinion, ceased to be in force on the $17^{\text {th }}$ July 2018. A fundamental legal effect of the of the legislator's decision to repeal them is decriminalization of behaviors covered by the statutory description of the type of prohibited act. The most important conclusion of the expert opinion is even in the period of time the provisions of article 55a paragraphs $1-2$ were in force representatives of German minority in Poland had the possibility of conducting activities in favor of "discovering, elaborating and commemorating the tragic fate of the German civilian population, embedded in the system of post-war labor camps" under condition they did not contradict the facts.
\end{abstract}

Keywords: Institute of National Remembrance, crime, national minorities

Słowa kluczowe: Instytut Pamięci Narodowej, przestępczość, mniejszości narodowe

Ekspert ds. legislacji BAS; pawel.bachmat@sejm.gov.pl.

\section{Przedmiot opinii}

Przedmiotem opinii jest analiza wybranych aspektów uregulowania art. 55a ust. 1-3 ustawy z 18 grudnia 1998 r. o Instytucie Pamięci Narodowej - Komisji Ścigania Zbrodni przeciwko Narodowi Polskiemu (t.j. Dz.U. 2016, poz. 1575, ze zm.; dalej: ustawa o IPN). Przepis art. 55a ust. 1-3 zostały wprowadzone ustawą z 26 stycznia 2018 r. o zmianie ustawy o Instytucie Pamięci Narodowej - Komisji Ścigania Zbrodni przeciwko Narodowi Polskiemu, ustawy o grobach i cmenta-

1 Opinia prawna na temat typów czynów zabronionych oraz kontratypu określonych $w$ art. 55a ust. 1-3 ustawy o Instytucie Pamięci Narodowej - Komisji Ścigania Zbrodni sporządzona 26 lipca 2018 r. na zlecenie posła; BAS-WAP 794/18. 
rzach wojennych, ustawy o muzeach oraz ustawy o odpowiedzialności podmiotów zbiorowych za czyny zabronione pod groźbą kary (Dz.U. 2018, poz. 369). Weszły w życie z dniem 1 marca 2018 r. w następującym ujęciu redakcyjnym: 1. Kto publicznie i wbrew faktom przypisuje Narodowi Polskiemu lub Państwu Polskiemu odpowiedzialność lub współodpowiedzialność za popetnione przez III Rzeszę Niemieckg zbrodnie nazistowskie określone w art. 6 Karty Międzynarodowego Trybunału Wojskowego załaczonej do Porozumienia międzynarodowego w przedmiocie ścigania i karania głównych przestępców wojennych Osi Europejskiej, podpisanego w Londynie dnia 8 sierpnia 1945 r. (Dz. U. z 1947 r. poz. 367), lub za inne przestępstwa stanowiące zbrodnie przeciwko pokojowi, ludzkości lub zbrodnie wojenne lub w inny sposób rażąco pomniejsza odpowiedzialność rzeczywistych sprawców tych zbrodni, podlega grzywnie lub karze pozbawienia wolności do lat 3. Wyrok jest podawany do publicznej wiadomości.

2. Jeżeli sprawca czynu określonego w ust. 1 działa nieumyślnie, podlega grzywnie lub karze ograniczenia wolności.

3. Nie popetnia przestępstwa sprawca czynu zabronionego określonego w ust. 1 i 2, jeżeli dopuścił się tego czynu w ramach działalności artystycznej lub naukowej.

W związku z cytowanym wyżej brzmieniem art. 55a ust. 1-3 ustawy o IPN wyrażono obawę, co do możliwości pogodzenia działań przedstawicieli niemieckiej mniejszości w Polsce prowadzonych na rzecz: odkrywania, opracowywania i upamiętniania tragicznych losów cywilnej ludności niemieckiej, osadzonej w systemie powojennych obozów pracy z zakresem kryminalizacji wyznaczonym na podstawie powołanych przepisów ustawy o IPN. W szczególności zaś zwrócono uwagę na zachodzącą obawę pociągnięcia do odpowiedzialności karnej osób zaangażowanych w tego typu działalność, jak również świadków wydarzeń tamtych lat publicznie prezentujących swoje wspomnienia. Wątpliwości te zostały ujęte w następujące pytaniach:

„1) Czy art. 55a ustawy może w sposób obiektywny utrudnić bądź też zahamować proces odkrywania systemu zbrodni powojennych na terenie Polski oraz oddawania czci niemieckim ofiarom tychże zbrodni, w przestrzeni publicznej lub w mediach?

2) Historia wielu powojennych obozów pracy, prowadzonych również przez administrację polską, nie została jeszcze odkryta i odpowiednio zbadana. W związku z tym rodzi się pytanie, czy art. 55a ustawy może narażać na odpowiedzialność karną osoby, które w działaniach publicznych i medialnych będą zajmowały się opracowywaniem tej trudnej i nieodkrytej jeszcze historii lub będą o niej opowiadać, wysuwając przy tym różne tezy o odpowiedzialności konkretnych osób, podmiotów, czy też państwa polskiego (w zależności od źródeł, z których korzystają). W opinii środowiska [które reprezentuje poseł zgłaszający wątpliwości] art. 55a może być wykorzystywany jako narzędzie do walki z osobami, które na forum publicznym lub medialnym będą przypisywać odpowiedzialność państwu polskiemu za przestępstwa stanowiące zbrodnie przeciw- 
ko pokojowi, ludzkości lub zbrodnie wojenne w okresie powojennym w oparciu o wyniki swoich badań lub posługując się już dostępnymi opracowaniami lub badaniami, które w danym momencie będą prowadzone przez historyków i naukowców. Również świadkowie tamtych zbrodni, którzy opowiedzą o nich na forum publiczno-medialnym na podstawie swojej wiedzy i pamięci z wydarzeń tamtych lat, mogą być narażeni na odpowiedzialność karną. Czy obawy te w związku z art. 55a są uzasadnione?

3) W jaki sposób organy powołane do ścigania przestępstwa $z$ art. 55a ust. 3 będą rozgraniczać działalność artystyczną lub naukową danego naukowca/historyka od jego wypowiedzi w mediach? W jaki sposób będzie dokonywana ocena, czy dana wypowiedź miała charakter naukowy, czy publicystyczny?”.

Należy zastrzec, że zgodnie z art. 1 pkt 2 ustawy z 27 czerwca 2018 r. o zmianie ustawy o Instytucie Pamięci Narodowej - Komisji Ścigania Zbrodni przeciwko Narodowi Polskiemu oraz ustawy o odpowiedzialności podmiotów zbiorowych za czyny zabronione pod groźbą kary (Dz.U. 2018, poz. 1272) uregulowanie art. 55a ustawy o IPN, będące punktem odniesienia dla sformułowanych wyżej pytań, ulega uchyleniu po upływie 14 dniu od ogłoszenia ustawy nowelizującej, które nastąpiło 2 lipca 2018 r. Przepisy art. 55a ust. 1-3 przestały zatem obowiązywać z dniem 17 lipca 2018 r.

Przedstawiona opinia uwzględnia stan prawny na dzień jej sporządzenia, została przygotowana na podstawie następujących aktów normatywnych:

- ustawy z 18 grudnia 1998 r. o Instytucie Pamięci Narodowej - Komisji Ścigania Zbrodni przeciwko Narodowi Polskiemu,

- ustawy z 26 stycznia 2018 r. o zmianie ustawy o Instytucie Pamięci Narodowej - Komisji Ścigania Zbrodni przeciwko Narodowi Polskiemu, ustawy o grobach i cmentarzach wojennych, ustawy o muzeach oraz ustawy o odpowiedzialności podmiotów zbiorowych za czyny zabronione pod groźbą kary i wszedł w życie; dalej: nowelizacja ustawy o IPN z 26 stycznia 2018 r.,

- ustawy z 27 czerwca 2018 r. o zmianie ustawy o Instytucie Pamięci Narodowej - Komisji Ścigania Zbrodni przeciwko Narodowi Polskiemu oraz ustawy o odpowiedzialności podmiotów zbiorowych za czyny zabronione pod groźbą kary; dalej: nowelizacja ustawy o IPN z 27 czerwca 2018 r.,

- konwencji w sprawie zapobiegania i karania zbrodni ludobójstwa uchwalonej przez Zgromadzenie Ogólne Narodów Zjednoczonych 9 grudnia 1948 r., Dz.U. 1952, nr 2, poz. 9; dalej: konwencja ONZ z 1948 r.,

- ustawy z 6 czerwca 1997 r. - Kodeks karny, t.j. Dz.U. 2017, poz. 2204, ze zm.; dalej: Kodeks karny lub k.k.,

- ustawy z 6 czerwca 1997 r. - Kodeks postępowania karnego, t.j. Dz.U. 2017, poz. 1904, ze zm.; dalej: k.p.k.,

- ustawy z 6 czerwca 1997 r. - Kodeks karny wykonawczy, t.j. Dz.U. 2018, poz. 652 , ze zm.; dalej: k.k.w. 


\section{Uzasadnienie prawne}

\section{Zmiana stanu prawnego w zakresie opiniowanych przepisów ustawy o IPN}

Jak wskazano wyżej, przepisy art. 55a ust. 1-3 ustawy o IPN weszły w życie z dniem 1 marca 2018 r., ale na skutek nowelizacji ustawy o IPN z 27 czerwca 2018 r. zostały uchylone i przestały obowiązywać z dniem 17 lipca 2018 r. Odnotowana zmiana normatywna doprowadziła do zaistnienia szczególnej sytuacji intertemporalnej przy kwalifikowaniu czynów określonych w uchylanych przepisach art. 55a ust. 1 i 2 ustawy o IPN, jak również zachowań realizowanych w granicach kontratypu $z$ art. 53 ust. 3 ustawy o IPN.

Zasadniczym skutkiem prawnym decyzji ustawodawcy o uchyleniu art. 55a ust. 1 i 2 ustawy o IPN jest dekryminalizacja zachowań objętych ustawowym opisem typu czynu zabronionego określonego $\mathrm{w}$ tych przepisach $\mathrm{w}$ jego umyślnej i nieumyślnej odmianie. Z praktycznego punktu widzenia oznacza to zatem, że od dnia 17 lipca 2018 r. czyn sprawcy realizujący znamiona opisane w uchylanych przepisach art. 55a ust. 1 albo art. 55a ust. 2 ustawy o IPN pozostaje na gruncie prawa karnego zachowaniem legalnym i nie podlega ściganiu.

Istotne jest tu jednak uczynienie zastrzeżenia, że wprowadzana zmiana w prawnej ocenie zdarzeń, których modelowy odpowiednik zapisany został w dyspozycjach uchylanych przepisów, ogranicza się do zakresu normowania prawa karnego. Nowelizacja ustawy o IPN z 27 czerwca 2018 r. nie uchyliła bowiem szczególnej, cywilnoprawnej podstawy ochrony dobrego imienia Rzeczypospolitej Polskiej i narodu polskiego, jaka przewidziana została w rozdziale 6c ustawy o IPN, w tym zwłaszcza w art. 53o ustawy o IPN, który stanowi, że: [d]o ochrony dobrego imienia Rzeczypospolitej Polskiej i Narodu Polskiego odpowiednie zastosowanie maja przepisy ustawy $z$ dnia 23 kwietnia 1964 r. - Kodeks cywilny (Dz. U. z 2017 r. poz. 459, 933 i 1132) o ochronie dóbr osobistych. Powództwo o ochronę dobrego imienia Rzeczypospolitej Polskiej lub Narodu Polskiego może wytoczyć organizacja pozarządowa w zakresie swoich zadań statutowych. Odszkodowanie lub zadośćuczynienie przystuguja Skarbowi Państwa.

Nie budzi przy tym wątpliwości, że w zakresie przesłanki „naruszenia dobrego imienia Rzeczypospolitej Polskiej lub Narodu Polskiego" mieszczą się różnorakie zachowania polegające na kłamliwym (wbrew faktom) przypisywaniu narodowi polskiemu lub państwu polskiemu odpowiedzialności lub współodpowiedzialności za popełnienie zbrodni, w tym zbrodni rodzajowo wskazanych w uchylanym art. 55a ust. 1 ustawy o IPN. Tak więc należy mieć na uwadze, że nawet po 17 lipca 2018 r. osoba dopuszczająca się kłamliwego (wbrew faktom) przypisania narodowi polskiemu lub państwu polskiemu odpowiedzialności lub współodpowiedzialności za popełnienie zbrodni rodzajowo wskazanych w uchylanym art. 55a ust. 1 ustawy o IPN, których dopuścił się kto inny, powinna liczyć się z możliwością poniesienia odpowiedzialności przed polskimi sądami z tytułu naruszenia 
dobrego imienia Rzeczypospolitej Polskiej lub narodu polskiego. Wspomniana odpowiedzialność zaktualizuje się w reżimie prawa cywilnego i może prowadzić do zasądzenia obowiązku wypłaty odszkodowania lub zadośćuczynienia na rzecz Skarbu Państwa. Tytułem uzupełnienia warto dodać, że, zgodnie z art. 53p ustawy o IPN, powództwo o ochronę dobrego imienia Rzeczypospolitej Polskiej lub narodu polskiego wytoczyć może również Instytut Pamięci Narodowej (w sprawach tych Instytut Pamięci Narodowej ma bowiem przyznaną zdolność sądową), a stosownie do art. 53q ustawy o IPN przepisy art. 53o i art. 53p ustawy o IPN znajdą zastosowanie niezależnie od tego, jakie prawo jest właściwe.

Wracając do kwestii dekryminalizacji zachowań objętych dyspozycją przepisów art. 55a ust. 1 i 2 ustawy o IPN, należy dodać, że logiczną konsekwencją uchylenia $\mathrm{z}$ dniem 17 lipca 2018 r. przepisów art. 55a ust. 1 i 2 ustawy o IPN było także uchylenie z tym samym dniem jej art. 55a ust. 3, przewidującego kontratyp (tj. okoliczność wyłączającą przestępność czynu z uwagi na brak jego bezprawności) legalizujący popełnienie czynów $\mathrm{z}$ art. 55a ust. 1 i 2 ustawy o IPN w ramach działalności artystycznej lub naukowej. Skoro zachowania stypizowane w uchylanych art. 55a ust. 1 i 2 ustawy o IPN nie będą stanowiły już przestępstwa, a więc będą na gruncie prawa karnego pierwotnie legalne, nie ma potrzeby utrzymywania podstawy prawnej dla ich wtórnej legalizacji w drodze wyłączenia ich bezprawnego charakteru na gruncie prowadzonej działalności artystycznej lub naukowej.

Skutek dekryminalizacyjny w odniesieniu do przestępstw z art. 55a ust. 1 i 2 ustawy o IPN, który zaktualizował się z dniem 17 lipca 2018 r., wpłynie przede wszystkim na ocenę zachowań przyszłych. Przepisy art. 55a ust. 1 i 2 ustawy o IPN obowiązywały jednak od 1 marca 2018 r. Tym samym w okresie wyznaczonym powołanymi datami, tj. od 1 marca do 17 lipca 2018 r., prawnokarna ocena zachowań stypizowanych $\mathrm{w}$ art. 55a ust. 1 i 2 ustawy o IPN była diametralnie odmienna. Podlegały one ściganiu i ukaraniu jako czyny zabronione ustawą karną. Nie można przy tym wykluczyć, że w zarysowanym okresie (tj. przed dekryminalizacją) jakieś osoby dopuściły się zachowań wypełniających znamiona typów czynów zabronionych określonych w przepisach art. 55a ust. 1 i 2 ustawy o IPN, a nawet że stały się one przedmiotem wszczętych postępowań karnych. W związku z tym należy rozważyć pytanie, czy ich sprawcy nadal powinni liczyć się z groźbą poniesienia odpowiedzialności karnej.

Ogólnej wskazówki do odpowiedzi na to pytanie udzielił ustawodawca, który w części ogólnej Kodeksu karnego zawarł normę zawierającą dyrektywę intertemporalną rozstrzygającą podobne sytuacje. Zgodnie z art. $4 \$ 1$ k.k., jeżeli w czasie orzekania obowiązuje ustawa inna niż w czasie popełnienia przestępstwa, stosuje się ustawę nową, jednakże należy stosować ustawę obowiązującą poprzednio, jeżeli jest względniejsza dla sprawcy. W analizowanym przypadku nie budzi wątpliwości, iż względniejsza dla sprawcy jest ustawa nowa (tj. nowelizacja ustawy o IPN z 27 czerwca 2018 r.), gdyż poddaje modelowy odpowiednik jego zachowania dekryminalizacji. Tak więc to ona znajdzie zastosowanie 
do oceny czynów mających miejsce w okresie od 1 marca do 17 lipca 2018 r., a będących przedmiotem postępowań, w których orzekanie nastąpi począwszy od dnia 17 lipca 2018 r. Z perspektywy oceny dokonywanej ex post zachowanie sprawcy zostanie zatem objęte skutkiem dekryminalizacyjnym.

Powyższe ustalenie materialnoprawne przełoży się od strony procesowej w zależności od stanu zaawansowania prowadzonego postępowania - na etapie postępowania przygotowawczego: na odmowę jego wszczęcia albo umorzenie postępowania już prowadzonego $z$ art. $17 \$ 1$ pkt 2 k.p.k. (czyn nie zawiera znamion czynu zabronionego), a na etapie postępowania sądowego - uniewinnienie (art. $414 \$ 1$ k.p.k. w związku z art. $17 \$ 1$ pkt 2 k.p.k.) $)^{2}$.

W celu zobrazowania w pełni sytuacji intertemporalnej na gruncie Kodeksu karnego należy jeszcze wspomnieć o przypadku osoby, wobec której organy wymiaru sprawiedliwości zdążyłyby przeprowadzić w całości postępowanie karne o przestępstwo $\mathrm{z}$ art. 55a ust. 1 albo ust. 2 ustawy o IPN, zakończone prawomocnym skazaniem przed dniem 17 lipca 2018 r. Otóż, zgodnie z dyrektywą zawartą w art. $4 \$ 4$ k.k., jeżeli według nowej ustawy czyn objęty wyrokiem nie jest już zabroniony pod groźbą kary, to skazanie ulega zatarciu z mocy prawa. Jeśli natomiast w momencie wejścia w życie nowej ustawy toczyłoby się postępowanie wykonawcze dotyczące takiego wyroku (wykonywana byłaby orzeczona kara pozbawienia wolności, kara ograniczenia wolności, ewentualnie trwałby okres próby w związku z warunkowym umorzeniem postępowania albo warunkowym zawieszeniem wykonania orzeczonej kary pozbawienia wolności), przedmiotowe postępowanie należałoby umorzyć z powołaniem się na art. $15 \$ 1$ k.k.w.

\section{Odniesienie się ex post do pytań}

\section{- Ad 1) i 2)}

W uchylonym art. 55a ust. 1 ustawy o IPN ustawodawca dokonał typizacji umyślnego typu czynu zabronionego polegającego na: publicznym i wbrew fak-

2 Należy nadmienić, że termin „orzekanie” rozumiany jest na gruncie art. $4 \$ 1$ k.k. szerzej niż np. „wyrokowanie”. Jak wskazuje L. Lachowski, „orzekanie” obejmuje zarówno wydanie wyroku w I instancji, jak i II instancji, a także na etapie orzekania kasacyjnego oraz na skutek wznowienia postępowania. Przez pojęcie orzekania należy rozumieć także wydawanie wyroku łącznego po zmianie ustawy (por. wyroki SN z: 9 stycznia 2015 r., sygn. akt IV KK 224/14, LEX nr 1622330; 7 listopada 2014 r., sygn. akt II KK 284/14, LEX nr 1539462; 17 lipca 2014 r., sygn. akt V KK 211/14, „Prokuratura i Prawo”, wkładka, 2014, nr 10, poz. 1, oraz 25 czerwca 2014 r., sygn. akt II KK 139/14, „Prokuratura i Prawo”, wkładka, 2014, nr 10, poz. 2). Orzekaniem będzie również wydawanie postanowienia o umorzeniu postępowania przygotowawczego, postanowienia o przedstawieniu zarzutów, postanowienia o stosowaniu środków zabezpieczających. Szerzej zob. J. Lachowski, Komentarz do art. 4 [w:] Kodeks karny. Komentarz, red. V. Konarska-Wrzosek, 2016, LEX nr 513055. 
tom przypisywaniu Narodowi Polskiemu lub Państwu Polskiemu odpowiedzialności lub współodpowiedzialności za popetnione przez III Rzeszę Niemiecka zbrodnie nazistowskie określone w art. 6 Karty Międzynarodowego Trybunatu Wojskowego załączonej do Porozumienia międzynarodowego w przedmiocie ścigania i karania głównych przestępców wojennych Osi Europejskiej, podpisanego w Londynie dnia 8 sierpnia 1945 r. (Dz. U. z 1947 r. poz. 367), lub za inne przestępstwa stanowiace zbrodnie przeciwko pokojowi, ludzkości lub zbrodnie wojenne lub w inny sposób rażącym pomniejszaniu odpowiedzialności rzeczywistych sprawców tych zbrodni.

Na podstawie art. 55a ust. 2 ustawy o IPN penalizacji poddana została także nieumyślna odmiana tego typu czynu zabronionego.

Odnosząc ustawowy opis typu czynu zabronionego $\mathrm{z}$ art. 55a ust. 1 i 2 ustawy o IPN, w jego odmianie umyślnej i nieumyślnej, do dwóch pierwszych pytań będących przedmiotem opinii, należy na wstępie zaznaczyć, iż zakres kryminalizacji wyznaczony na tej podstawie wykracza w znacznej części poza stany faktyczne wskazane w treści pytań. Jak można wywnioskować, historycznym punktem odniesienia dla sformułowanych wątpliwości jest okres przypadający po II wojnie światowej i działalność władz sowieckich oraz instalowanych przy ich pomocy polskojęzycznych ośrodków władzy, podejmowana w powojennym okresie wobec cywilnej ludności niemieckiej. Przy tak określonej granicy temporalnej należy uznać, że poza zakresem analizy pozostaje ten fragment norm dekodowanych na podstawie dawnych przepisów art. 55a ust. 1 i 2 ustawy o IPN, który obejmuje, dokonywane publicznie i wbrew faktom:

- przypisywanie narodowi polskiemu lub państwu polskiemu odpowiedzialności lub współodpowiedzialności za zachowania podjęte w trakcie trwania II wojny światowej, a więc zbrodnie popełnione w warunkach wojennych, w tym:

- popełnione przez III Rzeszę Niemiecką zbrodnie nazistowskie określone w art. 6 Karty Międzynarodowego Trybunału Wojskowego załączonej do Porozumienia międzynarodowego $\mathrm{w}$ przedmiocie ścigania i karania głównych przestępców wojennych Osi Europejskiej, podpisanego w Londynie 8 sierpnia 1945 r. (Dz.U. 1947, poz. 367),

- inne przestępstwa stanowiące zbrodnie przeciwko pokojowi,

- inne zbrodnie wojenne,

- lub dokonane w inny sposób rażące pomniejszanie odpowiedzialności rzeczywistych sprawców tych zbrodni.

Przy tym założeniu relewantny dla dalszej analizy pozostaje jedynie ten fragment norm dekodowanych na podstawie uchylonych przepisów art. 55a ust. 1 i 2 ustawy o IPN, który obejmuje:

- zakaz dokonywania publicznie i wbrew faktom przypisywania narodowi polskiemu lub państwu polskiemu odpowiedzialności lub współodpowiedzialności za inne przestępstwa stanowiące „zbrodnie przeciwko ludzkości”, 
- lub zakaz dokonywania w inny sposób - publicznie i wbrew faktom - rażącego pomniejszania odpowiedzialności rzeczywistych sprawców tych zbrodni.

Pojęcie „zbrodni przeciwko ludzkości” ma na gruncie typów czynu zabronionego $\mathrm{z}$ art. 55a ust. 1 i 2 ustawy o IPN charakter znamienia odsyłającego. W art. 3 ustawy o IPN zamieszczona została jego ustawowa definicja, według której: [z]brodniami przeciwko ludzkości sa w szczególności zbrodnie ludobójstwa $w$ rozumieniu Konwencji w sprawie zapobiegania i karania zbrodni ludobójstwa, przyjętej w dniu 9 grudnia 1948 r. (Dz. U. z 1952 r. poz. 9, 10 i 213 oraz z 1998 r. poz. 177), a także inne poważne prześladowania $z$ powodu przynależności osób prześladowanych do określonej grupy narodowościowej, politycznej, społecznej, rasowej lub religijnej, jeżeli były dokonywane przez funkcjonariuszy publicznych albo przez nich inspirowane lub tolerowane. Z kolei, zgodnie $\mathrm{z}$ zawartym $\mathrm{w}$ tym przepisie dalszym odesłaniem do konwencji ONZ z 1948 r., pod pojęciem „zbrodni ludobójstwa" rozumie się na gruncie art. II tego traktatu którykolwiek z wymienionych niżej czynów, dokonany w zamiarze zniszczenia w całości lub części grup narodowych, etnicznych, rasowych lub religijnych, jako takich:

- zabójstwo członków grupy,

- spowodowanie poważnego uszkodzenia ciała lub rozstroju zdrowia psychicznego członków grupy,

- rozmyślne stworzenie dla członków grupy warunków życia, obliczonych na spowodowanie ich całkowitego lub częściowego zniszczenia fizycznego,

- stosowanie środków, które mają na celu wstrzymanie urodzin w obrębie grupy,

- przymusowe przekazywanie dzieci członków grupy do innej grupy.

W tym miejscu należy jednak przypomnieć, że zgodnie ze stylizacją przyjętą w uchylonym art. 55a ust. 1 ustawy o IPN dla przypisania odpowiedzialności karnej za zachowanie realizujące znamiona typu czynu zabronionego określonego w art. 55a ust. 1 albo 2 ustawy o IPN konieczne było, aby sprawca sformułował swój przekaz „wbrew faktom”. Słowo fakt w ujęciu słownikowym oznacza zdarzenie, zjawisko, sytuację lub stan rzeczy, które rzeczywiście miały miejsce (zaszły w rzeczywistości) ${ }^{3}$. Sprawca czynu z art. 55a ust. 1 i 2 ustawy o IPN miał więc formułować przekaz obiektywnie nieprawdziwy (fałszywy), przypisując narodowi polskiemu lub państwu polskiemu m.in. odpowiedzialność za zbrodnie przeciwko ludzkości, za które ani naród, ani państwo polskie odpowiedzialne nie są. Dodać należy, że obiektywnie możliwa do ustalenia fałszywość twierdzeń sprawcy takiego czynu może wynikać albo z faktu, iż podnoszone przez niego wydarzenia nie miały w ogóle miejsca albo, wprawdzie miały miejsce, ale odpowiedzialność za ich wydarzenie się ponosi rodzajowo inny podmiot.

3 Inny słownik języka polskiego PWN. A...Ó, red. M. Bańko, Warszawa 2000, s. 393; Uniwersalny słownik języka polskiego, t. I, $A-G$, red. S. Dubisz, Warszawa 2003, s. 872. 
Wprowadzenie do ustawowego opisu typu czynu zabronionego znamienia uzależniającego odpowiedzialność sprawcy od nieprawdziwości przedstawionego przez niego przekazu wiązało się z ważną funkcją limitującą zakres kryminalizacji wyznaczonej na podstawie uchylonych uregulowań. Zabieg ten racjonalizował również dopuszczenie przez ustawodawcę skutku w postaci ograniczenia swobody wypowiedzi, z jakim należało się liczyć w czasie obowiązywania art. 55a ust. 1 i 2 ustawy o IPN. Karalne pozostawało zatem przypisywanie narodowi polskiemu lub państwu polskiemu jedynie obiektywnie niezgodnej z prawdą odpowiedzialności lub współodpowiedzialności za popełnienie wymienionych w treści art. 55a ust. 1 ustawy o IPN rodzajów zbrodni, w tym zbrodni przeciwko ludzkości. Z czysto logicznego punktu widzenia, wnioskując a contrario, kryminalizacją na podstawie uchylonych art. 55a ust. 1 i 2 ustawy o IPN nie były więc nigdy objęte przypadki, w których ktoś przypisywałby narodowi polskiemu lub państwu polskiemu odpowiedzialność lub współodpowiedzialność za określone $\mathrm{w}$ tych przepisach rodzaje zbrodni, pod warunkiem że czynił to, odwołując się do historycznie potwierdzonych zdarzeń, a więc działał w zgodzie z faktami.

To ostatnie twierdzenie wymaga jednak pewnego zniuansowania tak, aby jego ogólne brzmienie nie prowadziło do wyciągania fałszywych wniosków na gruncie pojęć narodu i państwa polskiego. W opisie trudnych czasów powojennych należy rekomendować zachowanie daleko posuniętej ostrożności w doborze słów identyfikujących podmioty odpowiedzialne za popełnienie określonych zbrodni, czego praktyczna egzemplifikacja mogłaby być dokonana jedynie na tle indywidualnych okoliczności sprawy. Jednak rozważając tę kwestię w oderwaniu od konkretnego stanu faktycznego, w ujęciu czysto hipotetycznym, należy zwrócić uwagę, iż nawet potwierdzenie faktycznego sprawstwa określonych osób czy grup nie może żadną miarą przełożyć się na konkluzję generalizującą, prowadzącą do przypisania odpowiedzialności za zbrodnie tych konkretnych osób całej zbiorowości narodowej, z której się wywodzą. Nie może to mieć miejsca przynajmniej do zaistnienia pewnego progu masowości zdarzeń, który jednak pozostaje trudny do granicznego uchwycenia, będąc w swojej istocie kryterium dalece uznaniowym. Tak więc nieostrożna generalizacja może prowadzić do formułowania twierdzeń nieuprawnionych, skutkujących odpowiedzialnością autora takich słów, który przed dniem 17 lipca 2018 r., zakładając, że nie podpadał pod dyspozycję uchylonego art. 55a ust. 3 ustawy o IPN, powinien był liczyć się nawet z groźbą pociągnięcia do odpowiedzialności karnej z art. 55a ust. 1 albo 2 ustawy o IPN. Z kolei w obowiązującym stanie prawnym osoba taka wciąż powinna liczyć się z możliwością poniesienia odpowiedzialności w trybie art. 53o ustawy o IPN z tytułu naruszenia dobrego imienia Rzeczypospolitej Polskiej lub narodu polskiego.

Podobną ostrożność należałoby zachować w związku z próbą przypisania odpowiedzialności państwu polskiemu np. za zbrodnie przeciwko ludzkości towarzyszące przetrzymywaniu cywilnej ludności niemieckiej w obozach pracy po II wojnie światowej. Powiązanie tych zdarzeń wedle kryterium geograficznego z ak- 
tualnym terytorium państwa polskiego nie powinno przesłaniać faktu, że substrat państwowości, jakim jest władza, pozostawał wówczas pod całkowitą kontrolą sowiecką. Przypisaniu odpowiedzialności za popełnienie określonych zbrodni konkretnemu państwu powinno z kolei towarzyszyć ustalenie, że kwestionowane na gruncie tej odpowiedzialności zdarzenia historyczne stanowią efekt autonomicznego procesu decyzyjnego organów państwa, które staje pod zarzutem. Trudno mówić o odpowiedzialności państwa polskiego za określone decyzje w sytuacji obecności na jego terytorium wojsk sowieckich oraz sowieckich dublerów w strukturze tworzonej administracji, jak również w sytuacji, w której nowo powstające, polskojęzyczne organy władzy tworzone były wbrew woli większości jego mieszkańców w oderwaniu, a nawet z jawnym pogwałceniem legitymacji demokratycznej oraz przy ignorowaniu istnienia polskich organów władzy na uchodźstwie i w podziemiu. Ten obraz zbliża sytuację, w której znalazła się polska państwowość, raczej do stanu państwa okupowanego, ofiary obcego imperializmu, aniżeli sprawcy bezprawia pociąganego do odpowiedzialności dziejowej.

Nie kwestionując faktu, że na terytorium państwa polskiego, w okresie powojennym, a także w czasie poprzedzającym zakończenie II wojny światowej, ludność cywilna, niezależnie zresztą od jej pochodzenia narodowego, stała się przedmiotem licznych represji ze strony tworzonego tam polskojęzycznego aparatu władzy czy struktur wojskowo-policyjnych ZSRR, należy podnieść, że sposób opisywania tych zdarzeń z perspektywy identyfikacji podmiotów odpowiedzialnych za wyrządzone bezprawie wymaga ponadstandardowej skrupulatności i z pewnością unikania posługiwania się upraszczającymi uogólnieniami. Należy przyznać, iż poszukiwanie adekwatnego aparatu pojęciowego nie jest na tym tle zadaniem łatwym, ale z pewnością nie niemożliwym. Nota bene pewna wskazówka terminologiczna została zawarta już w treści ustawy z 18 grudnia 1998 r. o Instytucie Pamięci Narodowej - Komisji Ścigania Zbrodni przeciwko Narodowi Polskiemu, która w przepisie art. 2 posługuje się kategoriami „zbrodni komunistycznych” oraz „funkcjonariuszy państwa komunistycznego”. Warto dodać, że przywołany tu sposób dookreślenia kręgu rzeczywistych sprawców zarzucanych zbrodni, zakładający powiązanie ich z wyznawaną ideologią, nie jest autorskim rozwiązaniem polskiego ustawodawcy. Już wcześniej został on wykorzystany np. w niemieckim dyskursie historyczno-publicystycznym, gdzie odpowiedzialność za okropieństwa II wojny światowej dość konsekwentnie wiązana bywa ostatnimi laty z działalnością „nazistów”, nie zaś Niemców, którzy, mimo niedowierzania połączonego ze sprzeciwem polskiej opinii publicznej, coraz częściej zyskują przy tej okazji status chronologicznie pierwszej ofiary nazistów.

Powracając do wątpliwości wyrażonych we wstępie niniejszej opinii, co do narażenia na odpowiedzialność karną - w okresie obowiązywania art. 55a ust. 1 i 2 ustawy o IPN - osób zajmujących się opracowywaniem historii powojennych obozów pracy działających na ziemiach polskich, warto zwrócić uwagę jeszcze na dwie kwestie. 
Po pierwsze, w okresie obowiązywania tych przepisów ustawodawca dopuszczał w wąskim zakresie możliwość legalnego wypełnienia znamion typów czynów zabronionych określonych $\mathrm{w}$ art. 55a ust. 1 i 2 ustawy o IPN na mocy kontratypu określonego w jej art. 55a ust. 3, zgodnie z którym nie popełniał przestępstwa ten, kto dopuszczał się tych czynów w ramach działalności artystycznej lub naukowej. Powyższa kwalifikacja prawnomaterialna przekładała się od strony procesowej - w zależności od stanu zaawansowania prowadzonego postępowania - na etapie postępowania przygotowawczego: na odmowę jego wszczęcia albo umorzenie postępowania już prowadzonego $\mathrm{z}$ art. $17 \S 1$ pkt 2 k.p.k. (ustawa stanowi, że sprawca nie popełnia przestępstwa), zaś na etapie postępowania sądowego - uniewinnienie (art. $414 \$ 1$ k.p.k. w związku z art. $17 \$ 1$ pkt 2 k.p.k.).

Powołany wyżej kontratyp nie obejmował natomiast innych rodzajów działalności publicznej w tym np. publicystycznej, dziennikarskiej czy politycznej. Oznaczało to, że osoba, która w swojej wypowiedzi publicznej, podkreślmy to wbrew faktom - przypisywała narodowi polskiemu lub państwu polskiemu odpowiedzialność lub współodpowiedzialność za zbrodnie wymienione $\mathrm{w}$ treści dyspozycji art. 55a ust. 1 ustawy o IPN lub w inny sposób rażąco pomniejszała odpowiedzialność rzeczywistych sprawców tych zbrodni, a nie dokonywała tego w ramach działalności artystycznej lub naukowej, tylko np. w ramach działalności czysto publicystycznej, albo bez powiązania z jakąkolwiek działalnością zawodową, prezentując to jako swój osobisty punkt widzenia, musiała liczyć się z pociągnięciem do odpowiedzialności karnej.

Po drugie, należy nadmienić, że prawdopodobieństwo popadnięcia w kolizję $\mathrm{z}$ prawnokarnym zakazem było wówczas stosunkowo łatwe $\mathrm{z}$ uwagi na przyjęte założenie kryminalizacyjne ścigania sprawców tak umyślnego, jak i nieumyślnego popełnienia typu czynu zabronionego $\mathrm{z}$ art. 55a ustawy o IPN. Odwołując się do zgeneralizowanych w art. 9 k.k. postaci strony podmiotowej czynu zabronionego, w grę wchodził zarówno zamiar bezpośredni, jak i zamiar ewentualny oraz nieumyślne odmiany strony podmiotowej: nieumyślność świadoma i nieumyślność nieświadoma.

Co to oznaczało w praktyce? Zagrożony karą był nie tylko sprawca działający ze złej woli, a więc ten, kto, mając świadomość obiektywnej nieprawdziwości głoszonych tez, przypisywał publicznie narodowi polskiemu lub państwu polskiemu odpowiedzialność lub współodpowiedzialność za zbrodnie wymienione w treści dyspozycji art. 55a ust. 1 ustawy o IPN lub w inny sposób rażąco pomniejszał odpowiedzialność rzeczywistych sprawców tych zbrodni, chcąc przy tym dopuścić się popełnienia czynu zabronionego $\mathrm{z}$ art. 55a ust. 1 ustawy o IPN (zamiar bezpośredni), albo przewidując taką możliwość na to się godził (zamiar ewentualny). Ściganiu podlegała także osoba działająca nieumyślnie, która nie miała wprawdzie zamiaru popełnienia czynu zabronionego, ale nie dochowała też wymaganych $\mathrm{w}$ tych okolicznościach standardów ostrożności, zakładających konieczność uprzedniego potwierdzenia głoszonych publicznie 
tez wedle kryterium ich fałszywości bądź prawdziwości i niegłoszenie tez nieprawdziwych, pozostających w kolizji z faktami. Na tej zasadzie odpowiedzialności karnej podlegał sprawca nieumyślnego popełnienia czynu zabronionego, którego stosunek psychiczny do czynu zabronionego, w tym do będącego jego składową nieprawdziwego (wbrew faktom) „przypisywania odpowiedzialności lub współodpowiedzialności” albo „rażącego umniejszania odpowiedzialności rzeczywistych sprawców”, mógł przybrać jedną z dwóch postaci. Sprawca taki mógł, po pierwsze, przewidywać możliwość popełnienia czynu zabronionego, tj. obejmować swoją świadomością wątpliwość, że głoszone przez niego tezy mogą kolidować z faktami, a mimo to bezpodstawnie przypuszczać, że nie doprowadzi to do postawienia mu zarzutu karnego (nieumyślność świadoma). W drugim scenariuszu sprawca przestępstwa $\mathrm{z}$ art. 55a ust. 2 ustawy o IPN nie uświadamiał sobie nawet, że wygłoszone pod adresem narodu lub państwa polskiego zarzuty są nieprawdziwe, choć w danych okolicznościach mógł to przewidzieć (nieumyślność nieświadoma).

To w ówczesnym ściganiu zachowań popełnionych w nieuświadomionej nieumyślności leżało niebezpieczeństwo łatwego popadnięcia w kolizję z art. 55a ust. 2 ustawy o IPN osób działających $\mathrm{z}$ ignorancji. Ale nawet w tym przypadku, zakładającym, że sprawca typu czynu zabronionego z art. 55a ust 2 ustawy o IPN dopuścił się swojego zachowania nieświadomie, w stanie osobistej niewiedzy, punktem odniesienia dla jego odpowiedzialności były fakty już historycznie potwierdzone. Innymi słowy, nie byłoby możliwe skuteczne przypisanie odpowiedzialności karnej z art. 55a ust. 2 ustawy o IPN osobie, która, działając w warunkach braku historycznych ustaleń, próbowała w dobrej wierze dokonać samodzielnego ich odkrycia, co istotne, działając poza sferą naukową (działalność naukowa była bowiem już objęta kontratypem z ówczesnego art. 55a ust. 3 ustawy o IPN), na pewnym etapie doszła do pewnych ustaleń, które upubliczniła, a które następnie zostały zakwestionowane, gdyż chronologicznie późniejsze badania im zaprzeczyły. Należy przyjąć, że taka osoba nie popełniała przestępstwa ze względu na to, iż jej zachowanie miało znamiona działania w usprawiedliwionym błędzie, co do okoliczności stanowiącej znamię czynu zabronionego, w tym wypadku w błędzie co do znamienia „wbrew faktom”, co skutkowało, zgodnie $\mathrm{z}$ art. $28 \$ 1$ k.k., wyłączeniem jej zawinienia, a przez to przestępności popełnionego przez nią czynu ${ }^{4}$.

4 Możliwość odniesienia błędu co do faktu do czynów popełnionych nieumyślnie zaistniała z dniem 1 lipca 2015 r. na skutek wejścia w życie nowelizacji art. $28 \$ 1$ k.k., dokonanej art. 1 pkt 4 ustawy z 20 lutego 2015 r. o zmianie ustawy - Kodeks karny oraz niektórych innych ustaw, Dz.U. poz. 396. Szerzej na ten temat zob. m.in.: P. Kozłowska-Kalisz, Komentarz aktualizowany do art. 28 [w:] M. Budyn-Kulik, P. Kozłowska-Kalisz, M. Kulik, M. Mozgawa, Kodeks karny. Komentarz aktualizowany, 2018, LEX nr 560561; J. Lachowski, Komentarz do art. 28 [w:] Kodeks karny. Komentarz, red. V. Konarska-Wrzosek, 2016,LEX nr 513081. 


\section{- Ad 3)}

Jak wskazano już we wcześniejszej części niniejszej opinii, uchylony przepis art. 55a ust. 3 ustawy o IPN regulował instytucję kontratypu, wyłączającego przestępność czynów określonych w uchylonym art. 55a ust. 1 i 2 ustawy o IPN, a popełnionych $\mathrm{w}$ ramach działalności artystycznej lub naukowej. Uchylony przepis art. 55a ust. 3 ustawy o IPN obowiązywał w dniach do 1 marca do 17 lipca 2018 r. W tym czasie ustawa z 18 grudnia 1998 r. o Instytucie Pamięci Narodowej - Komisji Ścigania Zbrodni przeciwko Narodowi Polskiemu nie definiowała bliżej pojęć „działalności artystycznej” oraz „działalności naukowej”. Oznacza to, że w zakresie identyfikacji desygnatów pojęć „działalności artystycznej” oraz „działalności naukowej” dla potrzeb wykładni art. 55a ust. 3 ustawy o IPN ustawodawca zdecydował się pozostawić swobodę organom stosującym prawo. Pragmatyka postępowania w takiej sytuacji wskazuje, że podmiot stosujący prawo doprowadzi do zdekodowania zakresu rozpatrywanego pojęcia przy wykorzystaniu znanych nauce prawa metod wykładni tekstu prawnego ${ }^{5}$. Przy rekonstrukcji własnej zakresu tych pojęć dla potrzeb wykładni art. 55a ust 3 ustawy o IPN w grę powinno wejść m.in. poszukiwanie sposobów ujęcia tych pojęć lub ich odpowiedników ${ }^{6}$ (definicyjnego lub tylko kontekstowego) w innych aktach normatywnych składających się na obowiązujący porządek prawny. W procesie wykładni organ stosujący prawo może poszukiwać wsparcia także w relewantnych orzeczeniach judykatury oraz poglądach doktryny ${ }^{7}$.

Zważywszy na fakt, że ustawodawca zdecydował się uchylić przepis art. 55a ust. 3 ustawy o IPN, próba rekonstrukcji tych pojęć dla potrzeb niniejszej opinii traci merytoryczną zasadność.

\section{Podsumowanie}

1. Przepisy art. 55a ust. 1-3 ustawy z 18 grudnia 1998 r. o Instytucie Pamięci Narodowej - Komisji Ścigania Zbrodni przeciwko Narodowi Polskiemu, będące punktem odniesienia dla pytań sformułowanych we wstępie, przestały obo-

5 Zob. szerzej na ten temat np. L. Morawski, Zasady wykładni prawa, Toruń 2006.

6 Dla przykładu w art. 2 pkt 3 ustawy z 30 kwietnia 2010 r. o zasadach finansowania nauki (t.j. Dz.U. 2018, poz. 87, ze zm.) zdefiniowany został termin „badania naukowe”.

7 Zob. m.in.: M. Budyn-Kulik, M. Kulik, Wolność działalności artystycznej jako okoliczność wyłączająca odpowiedzialność karna [w:] Prawnokarne aspekty wolności: materiały z konferencji, Arłamów16-18 maja 2005 r., Warszawa 2006, s. 233-250; T. Gardocka, Czy w polskim prawie karnym potrzebny jest kontratyp sztuki? „Palestra” 2015, nr 1-2, s. 28 i n.; S. Jarosz-Żukowska, Ł. Żukowski, Wolność badań naukowych i nauczania [w:] Realizacja i ochrona konstytucyjnych wolności i praw jednostki w polskim porządku prawnym, red. M. Jabłoński, Wrocław 2014, s. 718 i n.; C. Starck, Wolność badań naukowych i jej granice, „Przegląd Sejmowy” 2007, nr 3, s. 45 i n. 
wiązywać z dniem 17 lipca 2018 r. Zasadniczym skutkiem prawnym decyzji ustawodawcy o uchyleniu art. 55a ust. 1 i 2 ustawy o IPN jest dekryminalizacja zachowań objętych ustawowym opisem typu czynu zabronionego określonego w tych przepisach w jego umyślnej i nieumyślnej odmianie. Oznacza to, że od dnia 17 lipca 2018 r. zachowanie realizujące znamiona opisane w uchylanych przepisach art. 55a ust. 1 albo art. 55a ust. 2 ustawy o IPN pozostaje na gruncie prawa karnego legalne i nie podlega ściganiu.

2. Walor legalności zachowań, których modelowy odpowiednik zapisany został w dyspozycjach uchylonych przepisów art. 55a ust. 1 i 2 ustawy o IPN, ogranicza się do zakresu normowania prawa karnego. Fakt dekryminalizacji nie przekłada się natomiast na ewentualną prawną ocenę tych zachowań dokonywaną przez organy państwa na gruncie innych gałęzi prawa, w tym w szczególności prawa cywilnego.

3. Sprawca dopuszczający się kłamliwego (wbrew faktom) przypisania narodowi polskiemu lub państwu polskiemu odpowiedzialności lub współodpowiedzialności za popełnienie zbrodni, w tym zbrodni rodzajowo wskazanych w uchylonym art. 55a ust. 1 ustawy o IPN, których dopuścił się kto inny, nadal powinien liczyć się z możliwością poniesienia odpowiedzialności deliktowej przed polskimi sądami z tytułu naruszenia dobrego imienia Rzeczypospolitej Polskiej lub narodu polskiego w trybie art. 53o ustawy o IPN. Przypisanie tej odpowiedzialności dokonane na gruncie prawa cywilnego może prowadzić do zasądzenia obowiązku wypłaty odszkodowania lub zadośćuczynienia na rzecz Skarbu Państwa.

4. Dekryminalizacja w odniesieniu do przestępstw $\mathrm{z}$ art. 55a ust. 1 i 2 ustawy o IPN, która zaistniała z dniem 17 lipca 2018 r., wpłynie nie tylko na ocenę zachowań przyszłych. Zgodnie z regułą intertemporalną stosowania ustawy względniejszej wobec sprawcy (art. $4 \$ 1$ Kodeksu karnego), skutkiem dekryminalizacyjnym zostaną objęte także czyny popełnione w okresie obowiązywania przepisów art. 55a ust. 1 i 2 ustawy o IPN, tj. od 1 marca do 16 lipca 2018 r., a będące przedmiotem postępowań, w których orzekanie nastąpi począwszy od dnia 17 lipca $2018 \mathrm{r}$.

5. Osoba, wobec której organy wymiaru sprawiedliwości zdążyłyby przeprowadzić $\mathrm{w}$ całości postępowanie karne o przestępstwo $\mathrm{z}$ art. 55a ust. 1 albo ust. 2 ustawy o IPN, zakończone prawomocnym skazaniem przed dniem 17 lipca 2018 r., zgodnie z dyrektywą zawartą w art. $4 \$ 4$ Kodeksu karnego, skorzysta z zatarcia skazania z mocy prawa. Jeśli w dniu 17 lipca 2018 r. (tj. dniu wejścia w życie nowej ustawy) toczyłoby się postępowanie wykonawcze dotyczące takiego wyroku (wykonywana byłaby orzeczona kara pozbawienia wolności, kara ograniczenia wolności, ewentualnie trwałby okres próby w związku z warunkowym umorzeniem postępowania albo warunkowym zawieszeniem wykonania orzeczonej kary pozbawienia wolności), przedmiotowe postępowanie należałoby umorzyć z powołaniem na art. $15 \$ 1$ Kodeksu karnego wykonawczego. 


\section{Bibliografia}

Budyn-Kulik M., Kulik M., Wolność działalności artystycznej jako okoliczność wyłączajaca odpowiedzialność karna [w:] Prawnokarne aspekty wolności. Materiały z konferencji, Arłamów, 16-18 maja 2005 r., Warszawa 2006.

Gardocka T., Czy w polskim prawie karnym potrzebny jest kontratyp sztuki?, „Palestra” 2015, nr 1-2.

Inny słownik języka polskiego PWN. A...Ó, red. M. Bańko, Warszawa 2000.

Jarosz-Żukowska S., Żukowski Ł., Wolność badań naukowych i nauczania [w:] Realizacja i ochrona konstytucyjnych wolności i praw jednostki w polskim porządku prawnym, red. M. Jabłoński, Wrocław 2014.

Kozłowska-Kalisz P., Komentarz aktualizowany do art. 28 [w:] Kodeks karny. Komentarz aktualizowany, M. Budyn-Kulik, P. Kozłowska-Kalisz, M. Kulik, M. Mozgawa, 2018, LEX nr 560561.

Lachowski J., Komentarz do art. 28 [w:] Kodeks karny. Komentarz, red. V. Konarska-Wrzosek, 2016, LEX nr 513081.

Lachowski J., Komentarz do art. 4 [w:] Kodeks karny. Komentarz, red. V. Konarska-Wrzosek, 2016, LEX nr 513055.

Morawski L., Zasady wykładni prawa, Toruń 2006.

Starck C., Wolność badań naukowych i jej granice, „Przegląd Sejmowy” 2007, nr 3.

Uniwersalny słownik języka polskiego, t. I, A-G, red. S. Dubisz, Warszawa 2003. 


\title{
Możliwość wprowadzenia w prawie łowieckim regulacji dopuszczającej polowanie z łukiem ${ }^{1}$
}

\begin{abstract}
Possibility of introducing regulations admitting hunting with a bow into the Hunting Law (WAP-1449/18): Due to the principle of sustainable development and placement of the Hunting Law in the system of protection of natural environment, admission of archery as a method of hunting on the territory of the Republic of Poland may raise - according to the author - doubts. Extending the arsenal of hunting weapons by a bow could find a justification only in the situation, when, based on independent scientific research, it would confirm the thesis that the bow can be effective for purposes of the hunting economy and can constitute a weapon at least as humanitarian and safe as a hunting firearm.
\end{abstract}

Keywords: hunting, nature protection, Hunting Law, animals

Słowa kluczowe: łowiectwo, ochrona przyrody, prawo łowieckie, zwierzęta

Doktor nauk prawnych, ekspert ds. legislacji BAS; beata.binkowska-artowicz@sejm.gov.pl.

\section{Przedmiot opinii}

Przedmiot opinii stanowi kwestia możliwości wprowadzenia w prawie łowieckim regulacji dopuszczającej polowanie z łukiem, a dodatkowo ocena propozycji podmiotu zewnętrznego zawierającej projekt rozwiązań prawnych oraz ich uzasadnienie ${ }^{2}$.

Opinię przygotowano według stanu prawnego na dzień 21 czerwca $2018 \mathrm{r}$.

W opinii uwzględniono postanowienia następujących aktów prawnych:

- Konstytucja Rzeczypospolitej Polskiej z 2 kwietnia 1997 r., Dz.U. nr 78, poz. 483, ze zm.; dalej: Konstytucja RP,

1 Opinia prawna $w$ sprawie możliwości wprowadzenia $w$ prawie łowieckim regulacji dopuszczajacej polowanie z łukiem sporządzona 21 czerwca 2018 r. na zlecenie przewodniczącego Komisji Rolnictwa i Rozwoju Wsi; BAS-WAP 1449/18.

2 Pismo Polskiego Stowarzyszenia Myślistwa Łuczniczego z 7 maja 2018 r.; dalej: pismo z 7 maja 2018 r. 
- ustawa z 13 października 1995 r. - Prawo łowieckie, t.j. DzU. 2017, poz. 1295, ze zm.; dalej: u.p.ł.;

- ustawa z 21 sierpnia 1997 r. - o ochronie zwierząt, t.j. Dz.U. 2017, poz. 1840, ze zm.; dalej: u.o.z.,

- ustawa z 27 kwietnia 2001 r. - Prawo ochrony środowiska, t.j. Dz.U. 2018, poz. 799 , ze zm.,

- ustawa z 21 maja 1999 r. o broni i amunicji, t.j. Dz.U. 2017, poz. 1839, ze zm.; dalej: u.b.a.

Należy zastrzec, że Biuro Analiz Sejmowych nie jest uprawnione do wiążącej, formalnej oceny propozycji legislacyjnych przygotowanych przez podmioty zewnętrzne. Oceniana propozycja nie może zostać potraktowana jako projekt aktu prawnego, natomiast może stanowić podstawę do stworzenia hipotetycznej koncepcji legislacyjnej, w nawiązaniu do której zaprezentowana zostanie wykładnia odpowiednich przepisów Konstytucji Rzeczypospolitej Polskiej, Prawa łowieckiego oraz regulacji dotyczących ochrony środowiska oraz broni i amunicji.

\section{Uzasadnienie prawne}

\section{Zarys proponowanej koncepcji legislacyjnej}

Propozycja $^{3}$ dotyczy wprowadzenia strzelania z łuku myśliwskiego jako dodatkową formę polowania, obok dozwolonego obecnie tropienia, strzelania z myśliwskiej broni palnej i łowienia sposobami dozwolonymi zwierzyny żywej (zmiana art. 4 ust. 2 u.p.ł.). Propozycja obejmuje także nałożenie obowiązku posiadania zaświadczenia o posiadaniu uprawnień łuczniczych w przypadku wykonywania polowania $\mathrm{z}$ łukiem myśliwskim (wprowadzenie art. 42 ust. 2 pkt 4 u.p.ł.). Proponowana jest również delegacja dla ministra właściwego do spraw środowiska do wydania rozporządzenia określającego warunki i tryb wykonywania polowania z użyciem łuku myśliwskiego (wprowadzenie art. 42 ust. 12 u.p.ł.) oraz wprowadzenie w rozporządzeniu Ministra Środowiska z 23 marca 2005 r. w sprawie szczegółowych warunków wykonywania polowania i znakowania tusz (Dz.U. $\mathrm{nr}$ 61, poz. 548, ze zm.) definicji łuku myśliwskiego, grotu myśliwskiego i strzały myśliwskiej ( $\$ 2$ pkt 19-21 rozporządzenia). Zaproponowano też możliwość użycia łuku myśliwskiego do wykonywania polowania oraz odstrzału zwierząt stanowiących nadzwyczajne zagrożenie dla życia, zdrowia lub gospodarki człowieka oraz do polowania na zwierzynę grubą ( $\$ 3$ ust. 1 oraz ust. 3 rozporządzenia). Przedstawiono propozycję nowego rozdziału 8 rozporządzenia, określającego maksymalną odległość, w jakiej może znajdować się myśliwy od zwierzyny, do której oddaje strzał z łuku oraz siłę naciągu łuku i wagę strzały myśliwskiej przy polowaniach na poszczególne grupy zwierząt ( $\$ 48$ rozporządzenia).

3 Ibidem, cz. I. Proponowane rozwiąania prawne. 


\section{Prawo łowieckie a regulacje dotyczące ochrony środowiska}

$\mathrm{W}$ art. 1 u.p.ł. ustawodawca przewidział, że łowiectwo jest integralnym elementem ochrony środowiska przyrodniczego, co oznacza, że ustawa - Prawo łowieckie została poddana zasadom ochrony środowiska ${ }^{4}$. Wskazuje się, że niedopuszczalnym spłyceniem tej ustawy byłoby dopatrywanie się w niej tylko treści eksploatatorskich, ponieważ jest to przede wszystkim prawo ochronne ${ }^{5}$. Wykonywanie łowiectwa odbywa się z uwzględnieniem interesów ochrony przyrody $\mathrm{y}^{6}$.

Zgodnie z art. 3 u.p.ł.: celem łowiectwa jest: ochrona, zachowanie różnorodności i gospodarowanie populacjami zwierząt łownych; ochrona i kształtowanie środowiska przyrodniczego na rzecz poprawy warunków bytowania zwierzyny; uzyskiwanie możliwie wysokiej kondycji osobniczej i jakości trofeów oraz właściwej liczebności populacji poszczególnych gatunków zwierzyny przy zachowaniu równowagi środowiska przyrodniczego; spetnianie potrzeb społecznych $w$ zakresie uprawiania myślistwa, kultywowania tradycji oraz krzewienia etyki i kultury łowieckiej. W odniesieniu do powyższych celów polityki łowieckiej w doktrynie trafnie podkreśla się, że powinny być one realizowane w zgodzie z Konstytucją RP ${ }^{7}$.

Na mocy art. 5 Konstytucji RP zapewnienie ochrony środowiska stanowi jeden $\mathrm{z}$ podstawowych celów państwa, a sama ochrona środowiska jest jednym $\mathrm{z}$ dóbr prawnych pozwalających na ograniczenie $\mathrm{w}$ drodze ustawy konstytucyjnych wolności i praw (art. 31 ust. 3 Konstytucji RP) ${ }^{8}$. Jak podkreśla się w literaturze przedmiotu, ostatni zwrot art. 5 Konstytucji RP ogranicza wszelką ingerencję w sprawy „środowiska” wymogiem przestrzegania zasady „zrównoważonego rozwoju". Wszędzie tam, gdzie miałoby dochodzić do ingerencji w „środowisko", należy dbać nie tylko o to, aby ingerencja ta była jak najmniejsza (najmniej szkodliwa), lecz by osiagane korzyści społeczne byly co najmniej proporcjonalne, społecznie adekwatne do strat, jakie się wówczas ponosi ${ }^{10}$. Najważniejszą natomiast częścią składową systemu ochrony środowiska jest ochrona przyrody ${ }^{11}$.

$\mathrm{Z}$ art. 127 ust. 2 pkt 3 ustawy - Prawo ochrony środowiska wynika, że ochrona zwierząt oraz roślin jest realizowana w szczególności poprzez ograniczanie

R. Stec, Łowiectwo w prawie polskim i europejskim, Warszawa 2002, s. 182.

5 W. Radecki, Prawo łowieckie, Wrocław 1996, s. 36 i n., cyt. za: R. Stec, Łowiectwo w prawie polskim, op. cit., s. 120.

$6 \quad$ R. Stec, Łowiectwo w prawie polskim, op. cit., s. 38.

7 R. Stec, Uprawianie łowiectwa i prowadzenie gospodarki łowieckiej. Uwarunkowania administracyjnoprawne, cywilnoprawne i organizacyjne, Warszawa 2012, s. 161.

8 M. Bartoszewicz, Komentarz do art. 74 [w:] Konstytucja Rzeczypospolitej Polskiej. Komentarz, M. Haczkowska, Warszawa 2014, s. 155.

9 P. Sarnecki, Komentarz do art. 5 [w:] Konstytucja Rzeczypospolitej Polskiej. Komentarz, t. I, red. L. Garlicki, M. Zubik, Warszawa 2016.

10 Ibidem.

11 W. Radecki, Ustawa o ochronie przyrody. Komentarz, Warszawa 2006, s. 37-41, cyt. za: M. Bartoszewicz, Komentarz do art. 74, op. cit., s. 156. 
możliwości pozyskiwania dziko występujących zwierząt oraz roślin. Z kolei w art. 1 ust. 1 u.o.z. znajduje się tzw. formuła dereifikacyjna, zgodnie z którą: Zwierze, jako istota żyjaca, zdolna do odczuwania cierpienia, nie jest rzecza ${ }^{12}$. Następnie w art. 5 u.o.z. ustawodawca zawarł bezwzględny nakaz humanitarnego traktowania każdego zwierzęcia, a z art. 33 ust. 1a tej ustawy wynika konieczność humanitarnego uśmiercania zwierząt, to jest zadając przy tym minimum cierpienia fizycznego i psychicznego. Wyjątek od reguły zakazującej zabijanie zwierząt znajduje się natomiast w art. 6 ust. 1 pkt 6 u.o.z., zezwalającym na wykonywanie polowań, odstrzałów i ograniczania populacji zwierząt łownych.

$\mathrm{Z}$ powyższego wynika, że wykonywanie łowiectwa musi być podporządkowane podstawowej zasadzie uwzględnienia interesów ochrony przyrody ${ }^{13}$. Należy także zauważyć, że myślistwo jako synonim polowania jest terminem węższym od łowiectwa i jest dziedziną polegającą na zgodnym z prawem i etyką pozyskiwaniu zwierzą ${ }^{14}$. Łowiectwo polega bowiem na gospodarowaniu zwierzyną i nie jest sportem w rozumieniu art. 2 ust. 1 ustawy z 25 czerwca 2010 r. o sporcie (t.j. Dz.U. 2017, poz. 1463 , ze zm. $)^{15}$.

W obecnym stanie prawnym na mocy art. 4 ust. 2 u.p.ł. polowanie oznacza tropienie, strzelanie z myśliwskiej broni palnej, łowienie sposobami dozwolonymi zwierzyny żywej oraz łowienie zwierzyny przy pomocy ptaków łowczych za zgodą ministra właściwego do spraw środowiska - zmierzające do wejścia w jej posiadanie.

Natomiast zgodnie z ust. 3 powyższego przepisu kłusownictwo oznacza działanie zmierzające do wejścia w posiadanie zwierzyny m.in. w sposób niebędący polowaniem. Konsekwentnie, skoro strzelanie $\mathrm{z}$ łuku nie jest strzelaniem z myśliwskiej broni palnej, to działanie zmierzające do wejścia za jego pomocą w posiadanie zwierzyny jest kwalifikowane jako kłusownictwo. Działanie takie stanowi czyn zabroniony (art. 42aa pkt 12 u.p.t.) pod groźbą kary pozbawienia wolności do lat 5 (art. 53 pkt 5 u.p.ł.). W literaturze przedmiotu wymienia się wprost łuki jako zakazaną broń inną niż myśliwskąa ${ }^{16}$ Tytułem przykładu można także wskazać na stanowisko izby wyższej niemieckiego parlamentu federalnego w odniesieniu do regulacji zawartej w niemieckiej ustawie łowieckiej (Bundesjagdgesetz $\left.{ }^{17}\right)$, która $\mathrm{w} \$ 19$ ust. 1 pkt 1 wprost formułuje zakaz strzelania do zwierzyny z broni miotającej: Skoro strzelanie za pomoca luku i strzaly zostało

12 Na mocy art. 2 u.o.z. ustawa ta reguluje postępowanie ze zwierzętami kręgowymi.

13 R. Stec, Łowiectwo w prawie polskim, op. cit., s. 38.

14 R. Stec, Prawo łowieckie. Historia i teraźniejszość, Warszawa 1998, s. 72.

15 E.J. Krześniak, Kluby i organizacje sportowe w prawie polskim. Na tle rozwiązań zagranicznych, 2016, LEX.

16 W. Radecki, Komentarz do art. 53 ustawy - Prawo łowieckie [w:] System prawa karnego, t. 11, Szczególne dziedziny prawa karnego. Prawo karne wojskowe, skarbowe i pozakodeksowe, red. M. Bojarski, Warszawa 2014, s. 823.

17 BGBl. I S. 2849. 
udoskonalone $w$ taki sposób, $w$ który można oddawać strzały ze znacznej odległości z duża dokładnościa, to polowanie za pomoca łuku powinno być zabronione $z$ uwagi na częsty nieodpowiedni skutek takiego strzału oraz związane z tym cierpienie $z$ wierzą $t^{18}$.

Autorzy propozycji dążą natomiast nie tylko do depenalizacji, ale także do zalegalizowania polowania z łukiem.

W piśmie z 7 maja 2018 r. argumentuje się, że badania przeprowadzone na populacji sarny przez 5 lat w Danii wykazały, że postrzelenia stanowią mniej niż 5\% przypadków ${ }^{19}$. Jednakże nie wskazano, przez jaki ośrodek badania zostały przeprowadzone i z jakiej przyczyny wybrano ten gatunek zwierzyny łownej. Wskazano, że impuls bólowy w przypadku celnego strzału zostaje ograniczony do minimum ${ }^{20}$, natomiast nie przytoczono konkretnych wyników badań przeprowadzonych przez niezależnych ekspertów.

W tym miejscu należy zaznaczyć, że z uwagi na prawny charakter opinii nie sposób szerzej odnieść się do argumentacji dotyczącej humanitaryzmu łucznictwa myśliwskiego lub jego braku. Wskazać natomiast trzeba, że z uwagi na wspomnianą już konstytucyjną zasadę zrównoważonego rozwoju dopuszczenie polowania za pomocą łuku może budzić wątpliwości. Zasada ta, jak wskazuje się w orzecznictwie sądowoadministracyjnym, pełni przede wszystkim role dyrektywy wykładni. A to wtedy, gdy pojawiaja się watpliwości co do zakresu obowiązków, rodzaju obowiązków i sposobu ich realizacji, należy posiłkować się zasada zrównoważonego rozwoju. Pełni ona zatem rolę podobna do zasad wspótżycia społecznego czy społeczno-gospodarczego przeznaczenia w prawie cywilnym. W pierwszej kolejności do uwzględniania zasady zrównoważonego rozwoju obowiązany jest ustawodawca $w$ procesie stanowienia prawa ${ }^{21}$. Konsekwencją niezgodności aktu prawnego z zasadą zrównoważonego rozwoju może być zaskarżenie tego aktu do Trybunału Konstytucyjnego ${ }^{22}$.

\section{Cel proponowanej regulacji}

W literaturze przedmiotu nie ulega wątpliwości, że: prawo nie jest celem samym $w$ sobie, jest narzędziem stosowanym do osiagnięcia zamierzonych celów (...). Przyjmuje się, że działalność prawodawcy jest zawsze działalnościa celową. Takim,

18 Drucksache 7/4285 vom 6. November 1975, Sachgebiet 792, Deutscher Bundestag 7. Wahlperiode, s. 19, http://dipbt.bundestag.de/doc/btd/07/042/0704285.pdf [dostęp: 20 czerwca 2018 r.], tłum. własne.

19 J. Kylmä, Rozwój myślistwa łuczniczego w Europie, załącznik do pisma z 7 maja 2018 r.

20 Pismo z 7 maja 2018 r., cz. II. Uzasadnienie do proponowanych zmian prawa łowieckiego, pkt 6 - Impuls bólowy ograniczony do minimum.

${ }^{21}$ Wyrok Wojewódzkiego Sądu Administracyjnego w Gorzowie Wielkopolskim z 25 marca 2009 r., sygn. akt II SA/Go 825/08, http://orzeczenia.nsa.gov.pl/cbo/query.

22 Z. Bukowski, Konstytucyjne podstawy obowiązków państwa w zakresie ochrony środowiska, „Prawo i Środowisko” 2002, nr 4, s. 63. 
generalnie nakreślonym, ale i pierwszoplanowym celem dla prawa administracyjnego jest ochrona dobra wspólnego zharmonizowanego $z$ dobrem jednostek ${ }^{23}$.

Jak wskazano w piśmie z 7 maja 2018 r. w założeniu legalizacja polowania z łukiem nie miałaby doprowadzić do zastąpienia stosowanej dotychczas legalnie broni palnej, ale spowodowałaby rozszerzenie arsenału dla wszystkich myśliwych ${ }^{24}$. Zauważyć należy, że obecnie do celów polowania używana może być jedynie: myśliwska broń palna długa centralnego zapłonu, o lufach gwintowanych lub gładkich, $z$ wyłączeniem broni czarnoprochowej, pistoletów i rewolwerów, $z$ której po maksymalnym załadowaniu można oddać najwyżej sześć pojedynczych strzałów, $z$ tym że do magazynka broni samopowtarzalnej można załadować jednorazowo najwyżej dwa naboje ${ }^{25}$.

Jak zaznaczono, celem proponowanego rozwiązania jest spełnianie potrzeb społecznych w zakresie uprawiania myślistwa, kultywowania tradycji oraz krzewienia etyki i kultury łowieckiej ${ }^{26}$. Odnotować należy, że powyższe przesłanki zaczerpnięte zostały z cytowanego wyżej art. 3 pkt 4 u.p.ł. Podkreślenia wymaga, że użycie wyrażenia „kultywowanie tradycji” w odniesieniu do strzelania z łuku może być potraktowane jako dyskusyjne, ponieważ nowoczesne prawo łowieckie traktuje taki sposób pozyskiwania zwierzyny jako kłusownictwo. Dodatkowo, spełnienie potrzeb społecznych zostało wskazane jako realizacja interesu prawnego. Należy wskazać, że treść pojęcia interes prawny stanowi: publiczne prawo podmiotowe, rozumiane jako przyznanie przez przepis prawa jednostce konkretnych korzyści, które można realizować w postępowaniu administracyjnym ${ }^{27}$. Należy wyjaśnić, że z normy prawnej zawartej w art. 3 pkt 4 u.p.ł. nie wynika żadne publiczne prawo podmiotowe, którego może się domagać jednostka - w szczególności poprzez modyfikację obowiązującego ustawodawstwa.

Ponadto, proponuje się zamknięcie drogi do łucznictwa myśliwskiego dla osób pozbawionych prawa do posiadania broni czy skazanych za przestępstwa kłusownicze ${ }^{28}$. Pomijając fakt, że obecnie strzelanie do zwierzyny z łuku jest kłusownictwem, należy także dostrzec, że łuk nie został wymieniony jako broń

23 Z. Duniewska [w:] System prawa administracyjnego, t. 1, Instytucje prawa administracyjnego, red. R. Hauser, Z. Niewiadomski, A. Wróbel, Warszawa 2015, s. 104.

24 J. Kylmä, Rozwój myślistwa, op. cit.

25 Rozporządzenie Ministra Środowiska z 23 marca 2005 r. w sprawie szczegółowych warunków wykonywania polowania i znakowania tusz, Dz.U. nr 61, poz. 548, ze zm.

26 Pismo z 7 maja 2018 r., cz. II. Uzasadnienie do proponowanych zmian prawa łowieckiego.

27 J. Borkowski, Komentarz do art. 28 ustawy z dnia 14 czerwca 1960 r. - Kodeks postępowania administracyjnego (t. j. Dz. U. z 2017 r., poz. 1257 ze zm.) [w:] B. Adamiak, J. Borkowski, Kodeks postępowania administracyjnego. Komentarz, Warszawa 2006, s. 225.

28 Pismo z 7 maja 2018 r., op. cit., pkt 2 - Wysoki poziom akceptacji społecznej szansa na odnowienie wizerunku łowiectwa. 
w ustawie o broni i amunicji. Jednakże, jako narzędzie lub urządzenie, którego używanie może zagrażać życiu i zdrowiu, została wymieniona w powołanej ustawie broń cięciwowa w postaci kusz (art. 4 ust. 1 pkt 4 lit. b u.b.a.) - czyli również broń tzw. neurobalistyczna.

W uzasadnieniu proponowanego rozwiązania wskazuje się również, że brak efektów akustycznych w postaci huku wystrzału znacznie ogranicza płoszenie zwierząt ${ }^{29}$. Z uwagi na domniemaną racjonalność ustawodawcy zauważenia w tym miejscu wymaga, że wprawdzie, jak wyżej wskazano, łuk nie jest bronią w rozumieniu ustawy o broni i amunicji, natomiast nie wydaje się pozwolenia na broń szczególnie niebezpieczną, do której należy broń palna wyposażona w tłumik huku lub przystosowana do strzelania z użyciem tłumika huku (art. 10 ust. 5 pkt 3 u.b.a.).

Propozycję wprowadzenia polowania z łuku uzasadnia się m.in. pośrednio także szczególnym charakterem więzi rodzącej się między rodzicami a dzieckiem, wspólnie pokonującymi trasę terenowych zawodów łuczniczych ${ }^{30}$. Dostrzec należy, że użyto sformułowania „zawody łucznicze”. W tym miejscu warto podkreślić, że argumentacja oparta na stwierdzeniu, iż zastosowanie łuku w myślistwie doprowadzi do zwiększenia zainteresowania młodzieży, wskazuje na aktywność zaliczaną do sportu - podczas gdy łowiectwo sportem nie jest ${ }^{31}$. Łowiectwo oznacza bowiem ochronę zwierząt łownych (zwierzyny) i gospodarowanie ich zasobami w zgodzie z zasadami ekologii oraz zasadami racjonalnej gospodarki rolnej, leśnej i rybackiej (art. 1 u.p.ł.). Co więcej, przypomnienia wymaga, że ustawodawca polski w ostatnim czasie zabronił wykonywania polowania w obecności lub przy udziale dzieci do 18. roku życia (art. 42aa pkt 15 u.p.ł.) pod groźbą grzywny, kary ograniczenia wolności albo pozbawienia wolności do roku (art. 52 pkt 7 u.p.ł.) ${ }^{32}$. Trudno zatem przypuszczać, aby uzasadnienie omawianej propozycji zainteresowaniem niepełnoletnich osób nowym rodzajem broni używanej do polowania pozostawało w spójności z powyższą zmianą legislacyjną. Powyższe uzasadnienie nie wydaje się także trafne $\mathrm{z}$ uwagi na ustawowy zakaz wydawania pozwolenia na broń osobom niemającym ukończonych 21 lat (art. 15 ust. 1 pkt 1 u.b.a.). Należy zauważyć, że ustawowego wyjątku, dozwalającego na wydanie takiego pozwolenia osobie mającej ukończone 18 lat na wniosek m.in. Polskiego Związku Łowieckiego (art. 15 ust. 2 u.b.a.) nie należy interpretować rozszerzająco.

Ponadto, w uzasadnieniu do propozycji argumentuje się, że myśliwi łucznicy w sposób istotny realizują działania odpowiadające na realne potrzeby społecz-

29 Ibidem, pkt 8 - Łuk w gospodarce łowieckiej.

$30 \quad$ Ibidem, pkt 2 - Wysoki poziom akceptacji społecznej szansa na odnowienie wizerunku towiectwa.

31 E.J. Krześniak, Kluby i organizacje, op. cit.

32 Art. 1 ustawy z 22 marca 2018 r. o zmianie ustawy - Prawo łowieckie oraz niektórych innych ustaw, Dz.U. poz. 651. 
ne - np. redukcję zwierzyny na terenach miejskich i ograniczenie jej migracji na tereny podmiejskie, redukcję zwierzyny przyczyniającej się do znacznych szkód leśnych oraz rolnych ${ }^{33}$. Wydaje się, że powyższa argumentacja wymagałaby szczegółowych badań mających na celu ustalenie, czy łucznictwo myśliwskie rzeczywiście spełnia wymogi gospodarki łowieckiej, o której mowa w art. 4 ust. 1 u.p.ł.

Podsumowując, należy stwierdzić, że odnalezienie dobra wspólnego w umożliwieniu polowania z łuku może być problematyczne. Jak powyżej wskazano, istnienie tego dobra jest warunkiem koniecznym do wprowadzenia nowej regulacji. W orzecznictwie Trybunału Konstytucyjnego wskazano bowiem w kontekście art. 1 Konstytucji RP, że z faktu, iż Rzeczypospolita Polska jest dobrem wspólnym wszystkich obywateli: wynika (...) dyrektywa przedłożenia $w$ razie potrzeby dobra ogólnego ponad dobro indywidualne czy partykularny interes grupowy ${ }^{34}$. W odniesieniu do proponowanej koncepcji wydaje się, że nie została ona uzasadniona istnieniem takiego wspólnego dobra prawnie relewantnego, które mogłoby zostać pozyskane jedynie poprzez legalizację polowania $\mathrm{z}$ łuku.

\section{Polowanie z łuku a konstytucyjny obowiązek zapewnienia bezpieczeństwa}

Analizując przedmiotową koncepcję legislacyjną, nie należy pomijać konstytucyjnego obowiązku zapewnienia bezpieczeństwa obywatelom (art. 5 Konstytucji $\mathrm{RP})$. Obowiązek taki ciąży na państwu również w odniesieniu do wzajemnych relacji pomiędzy obywatelami ${ }^{35}$.

W tym kontekście istotna może się okazać nie tylko wspomniana kwestia bezgłośnego polowania (i obowiązujący zakaz wydawania pozwolenia na broń palną wyposażoną w tłumik huku jako na broń szczególnie niebezpieczną), ale także ogólne bezpieczeństwo podczas polowania.

Z uwagi na prawny charakter opinii nie sposób odnieść się merytorycznie do przedstawianych w tym zakresie argumentów, jednak zauważyć trzeba, że z jednej strony powołano się na fakt kilkunastokrotnie mniejszej szansy łucznika na skuteczne polowanie niż klasycznego myśliwego $\mathrm{z}$ bronią palną ${ }^{36}, \mathrm{z}$ drugiej natomiast strony podkreślono, że doświadczony myśliwy posługujący się łukiem uzyskuje podobne wyniki w pozyskiwaniu grubej zwierzyny jak myśliwi uzbrojeni w broń palną ${ }^{37}$ oraz że odpowiednio przygotowany i skonfigurowany sprzęt

33 Pismo z 7 maja 2018 r., op. cit., pkt 2 - Wysoki poziom akceptacji społecznej szansa na odnowienie wizerunku łowiectwa.

34 Wyrok Trybunału Konstytucyjnego z 30 stycznia 2001 r., sygn. akt K 17/00, OTK ZU 2001, nr 1, poz. 4.

35 M. Florczak-Wątor, Komentarz do art. 5 [w:] Konstytucja RP, t. I, Komentarz. Art. 1-86, red. M. Safjan, L. Bosek, Warszawa 2016.

36 Pismo z 7 maja 2018 r., op. cit., pkt 2 - Wysoki poziom akceptacji społecznej szansa na odnowienie wizerunku łowiectwa.

37 Ibidem, pkt 8 - Łuk w gospodarce łowieckiej. 
charakteryzuje się najwyższym wskaźnikiem bezpieczeństwa ${ }^{38}$. Żadna z powyższych tez nie znalazła jednak potwierdzenia w dokumentacji, zawierającej wyniki niezależnych badań czy opinie niezależnych ekspertów. W kontekście bezpieczeństwa na tle skuteczności myślistwa łuczniczego wątpliwości budzi także polowanie na terenach zurbanizowanych oraz w bezpośrednim sąsiedztwie zabudowań ${ }^{39}$.

\section{Podsumowanie}

Powyższa analiza prowadzi do kilku wniosków.

Z uwagi na zasadę zrównoważonego rozwoju oraz umieszczenie ustawy Prawo łowieckie w systemie ochrony środowiska przyrodniczego dopuszczenie strzelania z łuku jako metody polowania na terenie Rzeczypospolitej Polskiej może budzić wątpliwości. Jednocześnie wprowadzenie łuku jako dopuszczalnej broni myśliwskiej może budzić wątpliwości z uwagi na konstytucyjny obowiązek zapewnienia bezpieczeństwa obywatelom. Jednakże konieczność ograniczenia się do analizy prawnej omawianego zagadnienia nie pozwala na udzielenie jednoznacznej odpowiedzi.

Wydaje się, że wprowadzenie regulacji dopuszczającej polowanie z łukiem znalazłoby racjonalne uzasadnienie dopiero w sytuacji, gdy na podstawie niezależnie przeprowadzonych badań naukowych znalazłaby potwierdzenie teza, że łuk jest co najmniej tak samo skuteczny dla celów gospodarki łowieckiej oraz jednocześnie stanowi broń co najmniej tak samo humanitarną i bezpieczną jak dotychczas stosowana broń palna myśliwska.

\section{Bibliografia}

Bartoszewicz M., Komentarz do art. 74 [w:] Konstytucja Rzeczypospolitej Polskiej. Komentarz, red. M. Haczkowska, Warszawa 2014.

Borkowski J., Komentarz do art. 28 ustawy z dnia 14 czerwca 1960 r. - Kodeks postępowania administracyjnego (t. j. Dz. U. z 2017 r., poz. 1257 ze zm.) [w:] B. Adamiak, J. Borkowski, Kodeks postępowania administracyjnego. Komentarz, Warszawa 2006.

Bukowski Z., Konstytucyjne podstawy obowiązków państwa w zakresie ochrony środowiska, „Prawo i Środowisko” 2002, nr 4.

Duniewska Z. [w:] System prawa administracyjnego, t. 1, Instytucje prawa administracyjnego, red. R. Hauser, Z. Niewiadomski, A. Wróbel, Warszawa 2010.

38 Ibidem, pkt 3 - Najwyższe wskaźniki bezpieczeństwa podczas polowania.

39 Ibidem, pkt 4 - Polowanie na terenach zurbanizowanych oraz $w$ bezpośrednim sąsiedztwie zabudowań. 
Florczak-Wątor M., Komentarz do art. 5 [w:] Konstytucja RP, t. I, Komentarz. Art. 1-86, red. M. Safjan, L. Bosek, Warszawa 2016.

Gardocka T., Czy w polskim prawie karnym potrzebny jest kontratyp sztuki?, „Palestra” 2015, nr 1-2.

Krześniak E.J., Kluby i organizacje sportowe w prawie polskim. Na tle rozwiązań zagranicznych, Warszawa 2016.

Radecki W., Komentarz do art. 53 Prawa łowieckiego [w:] System prawa karnego, t. 11, Szczególne dziedziny prawa karnego. Prawo karne wojskowe, skarbowe i pozakodeksowe, red. M. Bojarski, Warszawa 2014.

Sarnecki P., Komentarz do art. 5 [w:] Konstytucja Rzeczypospolitej Polskiej. Komentarz, t. I, red. L. Garlicki, M. Zubik, Warszawa 2016.

Stec R., Łowiectwo w prawie polskim i europejskim, Warszawa 2002.

Stec R., Uprawianie łowiectwa i prowadzenie gospodarki łowieckiej. Uwarunkowania administracyjnoprawne, cywilnoprawne i organizacyjne, Warszawa 2012. 


\section{Związek partnerski czy małżeństwo? Ocena prawna poselskich projektów: ustawy o związku partnerskim oraz ustawy - Przepisy wprowadzające ustawę o związku partnerskim ${ }^{1}$}

\footnotetext{
Partnership or marriage? Evaluation of Deputies' Bills - on Partnership and Introductory Provisions of the Act on Partnership (WAP-1448/18): In the author's opinion, the proposed provisions - contrary to their nomenclature - introduce an institution of samesex marriages. Therefore they may be considered incompatible with Article 18 of the Constitution of the Republic of Poland. The proposed regulations regarding the dissolution of the partnership provide less protection to the children of partners than the children of one of them adopted by the other, what is inconsistent with the constitutional principle of equality. Besides the bills contain many legal shortcomings.
}

Keywords: bill, partnership

Słowa kluczowe: projekt ustawy, związek partnerski

\section{Przedmiot opinii}

Opinia dotyczy poselskich projektów ustaw:

- o związku partnerskim, dalej: projekt o z.p.,

- Przepisy wprowadzające ustawę o związku partnerskim, dalej: projekt przep. wprow.u.z.p.,

W niniejszej opinii uwzględniono postanowienia następujących aktów prawnych:

- Konstytucja Rzeczypospolitej Polskiej z 2 kwietnia 1997 r., Dz.U. nr 78, poz. 483, ze zm.; dalej: Konstytucja lub Konstytucja RP,

Opinia prawna dotyczaca poselskiego projektu ustawy o zwiazku partnerskim oraz poselskiego projektu ustawy - Przepisy wprowadzajace ustawe o zwiąku partnerskim sporządzona 20 czerwca 2018 r. na zlecenie Szefa Kancelarii Sejmu; BAS-WAP $1448 / 18$. 
- ustawa z 25 lutego 1964 r. - Kodeks rodzinny i opiekuńczy, t.j. Dz.U. 2017, poz. 682 , ze zm.; dalej: k.r.o.,

- ustawa z 28 listopada 2014 r. - Prawo o aktach stanu cywilnego, t.j. Dz.U. 2016, poz. 2064, ze zm.; dalej: u.p.a.s.c.,

- ustawa z 23 kwietnia 1964 r. - Kodeks cywilny, t.j. Dz.U. 2018, poz. 1025; dalej: k.c.,

- ustawa z 4 lutego 2011 r. - Prawo prywatne międzynarodowe, t.j. Dz.U. 2015, poz. 1792,

- ustawa z 24 lipca 1998 r. o zmianie ustaw - Kodeks rodzinny i opiekuńczy, Kodeks postępowania cywilnego, prawo o aktach stanu cywilnego, ustawy o stosunku Państwa do Kościoła katolickiego w Rzeczypospolitej Polskiej oraz niektórych innych ustaw, Dz.U. nr 117, poz. 757,

- estoński kodeks prawa rodzinnego (Perekonnaseadus/Family Law Act) z 18 listopada $2009 \mathrm{r}$.,

- niemiecki kodeks cywilny z 1896 r. (Bürgerliches Gesetzbuch),

- portugalski kodeks cywilny (Código Civil) z 25 listopada 1966 r.,

- rumuński kodeks cywilny (Codul civil) z 17 lipca 2009 r.,

- chilijska ustawa nr 19947 o małżeństwie cywilnym (Ley núm. 19.947, Nueva Ley de matrimonio civil).

\section{Zakres proponowanych zmian}

W uzasadnieniu do projektu ustawy o związku partnerskim zadeklarowano, że: [c]elem głównym (...) ustawy jest realizacja art. 18 Konstytucji - zapewnienia opieki i ochrony Rzeczypospolitej Polskiej rodzinom, które do tej pory takiej ochrony były pozbawione ${ }^{2}$. W tym celu w projekcie określa się prawne ramy funkcjonowania związków nieformalnych, wprowadzając możliwość wstąpienia w związek partnerski zarówno przez pary różnej, jak i tej samej płci.

Natomiast celem projektu ustawy - Przepisy wprowadzające ustawę o związku partnerskim jest nowelizacja 148 ustaw, których zmiana jest - zdaniem projektodawcy - konieczna ze względu na wprowadzenie nieznanej prawu polskiemu instytucji związku partnerskiego ${ }^{3}$.

2 Pkt 1 uzasadnienia do poselskiego projektu ustawy o związku partnerskim.

3 Zob. pkt 1 uzasadnienia do poselskiego projektu ustawy - Przepisy wprowadzające ustawę o związku partnerskim. 


\section{Ocena proponowanych rozwiązań}

\section{Wstęp}

Fundamentalnym problemem, który powstaje na gruncie obu przedstawionych projektów, jest konstytucyjna dopuszczalność wprowadzenia do systemu prawa polskiego instytucji związku partnerskiego, dlatego w pierwszej kolejności projekty winny zostać ocenione w świetle postanowień ustawy zasadniczej. Dokonując takiej oceny, przede wszystkim należy wziąć pod uwagę art. 18 Konstytucji, który stanowi, że: [m]ałżeństwo jako związek kobiety i mężczyzny, rodzina, macierzyństwo i rodzicielstwo znajduja się pod ochrona i opieka Rzeczypospolitej Polskiej.

Przytoczony wyżej przepis Konstytucji, choć nie definiuje w pełni pojęcia „małżeństwa”, to jednak expressis verbis wskazuje, że od strony podmiotowej tworzą je mężczyzna i kobieta. A contrario wynika z niego, że za małżeństwo nie może być uznany związek osób tej samej płci, a tym samym regulacja dopuszczająca zawieranie małżeństw jednopłciowych byłaby niezgodna $\mathrm{z}$ art. 18 Konstytucji ${ }^{4}$.

Chociaż projekty dotyczą wprowadzenia instytucji związku partnerskiego, to jednak kwestia stosowanej nomenklatury nie może być w tym przypadku rozstrzygająca, bowiem o tym, czy zarejestrowany związek dwojga osób jest małżeństwem, nie może przesądzać nazewnictwo, lecz charakter prawny tworzonej instytucji. W związku z tym, aby stwierdzić, czy wprowadzenie projektowanych rozwiązań byłoby zgodne z Konstytucją, warto porównać je z obowiązującymi unormowaniami dotyczącymi małżeństwa i, diagnozując występujące między nimi podobieństwa oraz różnice, ocenić, czy pomimo zmiany nazewnictwa kreowana przez projekty instytucja może uchodzić za małżeństwo.

\section{Małżeństwo a związek partnerski}

\section{- Przesłanki zawarcia małżeństwa oraz związku partnerskiego}

Mając na uwadze postanowienia Kodeksu rodzinnego i opiekuńczego, należy wskazać następujące przesłanki zawarcia małżeństwa:

- odmienność płci nupturientów (art. $1 \$ 1$ k.r.o.),

- jednoczesna obecność przyszłych małżonków składających oświadczenia woli (art. $1 \S 1$ k.r.o.) $)^{5}$,

4 Por. L. Garlicki, Komentarz do art. 18 [w:] Konstytucja Rzeczypospolitej Polskiej. Komentarz, t. I, red. L. Garlicki, M. Zubik, Warszawa 2016, s. 491-491; W. Borysiak, Komentarz do art. 18 [w:] Konstytucja RP, t. I, Komentarz. Art. 1-86, red. M. Safjan, L. Bosek, Warszawa 2016, nb 112-119.

5 Wyjątek od tej zasady formułuje art. 6 k.r.o. określający warunki zawarcia małżeństwa przez pełnomocnika. 
- złożenie zgodnych oświadczeń woli przed podmiotem uprawnionym do ich odebrania, tj.

- kierownikiem urzędu stanu cywilnego (art. $1 \$ 1$ oraz art. $9 \$ 1$ k.r.o.),

- duchownym, jeżeli kierownik urzędu stanu cywilnego sporządzi następnie akt małżeństwa (art. $1 \$ 2$ i 3 , art. $9 \$ 2$ k.r.o.),

- polskim konsulem lub osobą wyznaczoną do wykonywania funkcji konsula, jeżeli nupturienci przebywają za granicą (art. $1 \S 4$ k.r.o.).

Zgodnie z art. 2 k.r.o., jeżeli mimo niezachowania wyżej wskazanych wymogów sporządzony został akt małżeństwa, każdy, kto ma w tym interes prawny, może wystąpić z powództwem o ustalenie nieistnienia małżeństwa. Poza tym powództwo o ustalenie istnienia lub nieistnienia małżeństwa może wytoczyć także prokurator (art. 22 k.r.o.).

Natomiast $\mathrm{w}$ świetle postanowień projektu o z.p przesłankami zawarcia związku partnerskiego są:

- jednoczesna obecność partnerów składających oświadczenie woli (art. 7 ust. 4),

- złożenie zgodnych oświadczeń woli przed podmiotem uprawnionych do ich odebrania, tj.

- kierownikiem urzędu stanu cywilnego (art. 7 ust. 4),

- polskim konsulem lub osobą wyznaczoną do wykonywania funkcji konsula, jeżeli nupturienci przebywają za granicą (art. 7 ust. 8).

Zgodnie $\mathrm{z}$ art. 9 ust. 2 projektu o z.p., jeżeli pomimo niezachowania tych wymogów został sporządzony akt związku partnerskiego, prokurator oraz każdy, kto ma w tym interes prawny, może wystąpić z powództwem o ustalenie nieistnienia takiego związku'

Porównanie przesłanek warunkujących zawarcie małżeństwa i związku partnerskiego pokazuje, że są one niemalże identyczne. Jednak, co należy podkreślić, występujące różnice są zupełnie nieistotne. Zrozumiałe jest to, że przesłanka odmienności płci partnerów nie może być uwzględniona w przypadku związku partnerskiego, mającego wszak nadawać ramy prawne pożyciu par jednopłciowych. Z kolei przewidziana przez art. 6 k.r.o. możliwość zawarcia małżeństwa przez pełnomocnika jest rozwiązaniem dopuszczalnym tylko w wyjątkowych sytuacjach i nie przekreśla zasady osobistego stawiennictwa nupturientów. Poza tym brak analogicznych unormowań w projekcie o z.p. powinien być postrzegany raczej nie jako odmienność, ale jako wada proponowanej regulacji. Również możliwość wstąpienia w związek małżeński przed duchownym jest rozwią-

${ }_{6}$ W art. 9 ust. 2 błędnie odwołano się do art. 6 ust. 4 i 8 projektu o z.p., bowiem art. 6 nie jest podzielony na ustępy. W związku z tym można przypuszczać, iż chodzi o art. 7 ust. 4 i 8 projektu o z.p. 
zaniem fakultatywnym wobec podstawowego sposobu zawierania małżeństwa przed kierownikiem urzędu stanu cywilnego, a co więcej przez dziesięciolecia był to sposób nieznanym prawu polskiemu7. W związku z powyższym trzeba stwierdzić, iż prawna konstrukcja przesłanek (nie)istnienia małżeństwa oraz związku partnerskiego jest - przynajmniej co do istoty - taka sama.

\section{- Warunki formalne zawarcia małżeństwa oraz związku partnerskiego}

Zgodnie z art. $3 \$ 1$ k.r.o. osoby zamierzające zawrzeć małżeństwo powinny złożyć lub przedstawić kierownikowi urzędu stanu cywilnego dokumenty niezbędne do zawarcia małżeństwa, określone w odrębnych przepisach. Mając na uwadze, że art. $3 \$ 1$ k.r.o. odsyła do art. 76 u.p.a.s.c., należy stwierdzić, że analogiczne rozwiązania zawiera art. 7 ust. 2 projektu o z.p., który przewiduje, że osoby zamierzające zawrzeć związek partnerski powinny złożyć kierownikowi urzędu stanu cywilnego dokumenty, o których mowa w art. 76 u.p.a.s.c. Jedynym elementem nieistotnie różnicującym oba przepisy jest to, iż ten pierwszy dopuszcza złożenie lub przedstawienie dokumentów, ten drugi zaś tylko złożenie.

Pomiędzy przepisami dotyczącymi zawarcia małżeństwa i związku partnerskiego występują także inne podobieństwa. Według art. 8 projektu o z.p. oświadczenia o wstąpieniu w związek partnerski powinny być złożone publicznie, w obecności dwóch pełnoletnich świadków, czyli tak samo jak oświadczenia składane przez nupturientów mających zamiar zawrzeć małżeństwo (zob. art. 7 $\$ 1$ k.r.o.).

Ponadto należy zauważyć, że art. $7 \$ 3$ k.r.o. stanowi: Każda $z$ osób zawierających małżństwo składa oświadczenie o wstąpieniu w związek małżeński, powtarzajac za kierownikiem urzędu stanu cywilnego treść oświadczenia lub odczytując je na głos: „Świadomy/Świadoma praw i obowiązków wynikających z zawarcia małżństwa uroczyście oświadczam, że wstępuję $w$ związek małżeński $z$ (imię $i$ nazwisko drugiej z osób wstępujących $w$ związek mał̇̇enski) i przyrzekam, że uczynię wszystko, aby nasze małżeństwo było zgodne, szczęśliwe i trwałe”. Osoba niemogąca mówić składa oświadczenie o wstapieniu $w$ związek małżeński, podpisując protokół przyjęcia oświadczeń o wstapieniu w związek małżeński. Niemalże identyczne rozwiązania zawierają również przepisy projektu o z.p. I tak art. 7 ust. 4 przewiduje, że: [d]wie osoby jednocześnie obecne składaja przed kierownikiem urzędu stanu cywilnego oświadczenia, że wstępuja ze sobą w związek partnerski, powtarzając za kierownikiem urzędu stanu cywilnego treść oświadczenia lub odczytując je na głos. Osoba niemogąca mówić składa oświadczenie o wstąpieniu w związek, podpisując protokót przyjęcia oświadczeń o wstąpieniu w związek

Możliwość zawarcia małżeństwa przed duchownym została wprowadzona ustawą o zmianie ustaw - Kodeks rodzinny i opiekuńczy, Kodeks postępowania cywilnego, prawo o aktach stanu cywilnego, ustawy o stosunku Państwa do Kościoła katolickiego w Rzeczypospolitej Polskiej oraz niektórych innych ustaw. 
partnerski. Z kolei zgodnie z art. 7 ust. 5 projektu o z.p. oświadczenie, o którym mowa w art. 7 ust. 4 tego projektu, brzmi w sposób następujący: Świadomy/ Świadoma praw i obowiązków wynikajacych z zawarcia związku partnerskiego uroczyście oświadczam, że wstępuję w zwiąek partnerski z (imię i nazwisko drugiej $z$ osób wstępujących $w$ związek) i przyrzekam, że uczynię wszystko, aby nasz związek był zgodny, szczęśliwy i trwaty.

Innym elementem wspólnym występującym przy zawarciu małżeństwa i związku partnerskiego jest ogłoszenie przez kierownika urzędu stanu cywilnego, iż związek partnerski/małżeństwo został(-o) zawarte (art. $7 \$ 4$ k.r.o. oraz art. 7 ust. 6 projektu o z.p.).

Reasumując, należy stwierdzić, że w zakresie warunków formalnych zawarcia małżeństwa oraz związku partnerskiego brak jest istotnych różnic.

\section{- Przesłanki unieważnienia małżeństwa oraz związku partnerskiego}

W świetle art. 13 ust. 1-2 projektu o z.p. związek partnerski może być unieważniony tylko w następujących przypadkach:

- jeżeli został zawarty przez osobę, która nie ukończyła lat osiemnastu albo która ukończyła lat szesnaście, lecz nie uzyskała zezwolenia na zawarcie związku,

- jeśli decyzja o zawarciu związku nie została podjęta w sposób świadomy i swobodny,

- jeśli związek partnerski został zawarty między przysposabiającym i przysposabianym,

- jeśli przynajmniej jeden z partnerów pozostaje w poprzednio zawartym małżeństwie albo związku partnerskim,

- jeśli został zawarty między krewnymi w linii prostej, rodzeństwem, powinowatymi w linii prostej albo jeśli został zawarty między powinowatymi bez zgody sądu,

- jeśli oświadczenie o zawarciu związku partnerskiego zostało złożone pod wpływem błędu co do tożsamości drugiej strony albo pod wpływem bezprawnej groźby drugiej strony lub osoby trzeciej, jeżeli z okoliczności wynika, że składający oświadczenie mógł się obawiać, iż jemu samu lub innej osobie grozi poważne niebezpieczeństwo osobiste.

Zgodnie z postanowieniami projektu o z.p. unieważnienia związku partnerskiego z przyczyn, o których mowa wyżej w pkt 1-3, może żądać każdy z partnerów (art. 13 ust. 3), zaś z przyczyn, o których mowa w pkt 4-5, każdy kto, ma w tym interes prawny (art. 13 ust. 4). Co istotne, związku partnerskiego nie można unieważnić z powodu braku przepisanego wieku, jeżeli partner przed wytoczeniem powództwa ten wiek osiągnął (art. 5 ust. 3 projektu o z.p.). Z kolei unieważnienia związku partnerskiego z przyczyny, o której mowa wyżej w pkt 6, może żądać partner, który złożył oświadczenie dotknięte wadą. Przy czym nie można żądać unieważnienia związku partnerskiego po upływie sześciu miesięcy 
od wykrycia błędu lub ustania obawy wywołanej groźbą - a w każdym przypadku po upływie trzech lat od zawarcia związku (art. 13 ust. 5 projektu o z.p.).

WIEK W zasadzie $\mathrm{z}$ analogicznych przyczyn można obecnie unieważnić małżeństwo. A mianowicie, zgodnie z art. $10 \$ 2$ k.r.o. unieważnienia małżeństwa zawartego przez mężczyznę, który nie ukończył lat osiemnastu, oraz przez kobietę, która nie ukończyła lat szesnastu, albo bez zezwolenia sądu zawarła małżeństwo po ukończeniu lat szesnastu, lecz przed ukończeniem lat osiemnastu, może żądać każdy z małżonków. Ponadto art. $10 \$ 3$ k.r.o. przewiduje, że nie można unieważnić małżeństwa $\mathrm{z}$ powodu braku przepisanego wieku, jeżeli małżonek przed wytoczeniem powództwa ten wiek osiągnął. Projektowane przepisy dotyczące związków partnerskich różnią się od obowiązujących regulacji Kodeksu rodzinnego i opiekuńczego odnoszących się do małżeństw tym, że dopuszczają, aby partner płci męskiej zawarł związek po ukończeniu szesnastego roku życia za zgodą sądu oraz tym, iż zezwalają, by partner będący mężczyzną żądał unieważnienia związku z powodu braku przepisanego wieku po tym, gdy partnerka płci żeńskiej zaszła w ciążę.

Na marginesie warto wskazać, że art. 4 ust. 2 projektu o z.p. określa również takie same przesłanki wyrażenia przez sąd opiekuńczy zgody na zawarcie związku partnerskiego przez osobę, która ukończyła lat szesnaście, jak art. $10 \$ 1$ k.r.o., który dotyczy sądowej zgody na wstąpienie w związek małżeński przez kobietę, która ukończyła lat szesnaście.

Przysposobienie Kontynuując analizę dotyczącą przyczyn unieważnienia małżeństwa oraz związku partnerskiego, należy zauważyć, że art. $15 \$ 1$ k.r.o. przewiduje, iż nie mogą zawrzeć ze sobą małżeństwa przysposabiający i przysposobiony. Taki sam zakaz w odniesieniu do związków partnerskich zawiera także art. 5 ust. 1 projektu o z.p. W przypadku małżeństwa unieważnienia z powodu stosunku przysposobienia może żądać każdy z małżonków, zaś w świetle projektu unieważnienia związku partnerskiego - jak już wyżej wskazano - mógłby żądać każdy z partnerów. Jedyną różnicą między projektowanymi rozwiązaniami dotyczącymi związków partnerskich a obowiązującymi regulacjami odnoszącymi się do małżeństw jest to, iż brak jest odpowiednika $15 \$ 3$ k.r.o., który stanowi, że nie można unieważnić małżeństwa $\mathrm{z}$ powodu stosunku przysposobienia między małżonkami, jeżeli stosunek ten ustał. Należy z tego wnosić, iż projekt o z.p. zakłada nieco mniej rygorystyczne warunki unieważnienia związku partnerskiego z powodu istnienia stosunku przysposobienia między partnerami niż te, które ustanawia Kodeks rodzinny i opiekuńczy dla małżeństw.

BigAmia Jak wskazano wcześniej, w świetle projektu o z.p. unieważnić związek partnerski można, jeśli przynajmniej jeden z partnerów pozostaje w poprzednio zawartym małżeństwie albo związku partnerskim, a żądać jego unieważnienia z tej

$8 \quad$ Por. art. $10 \$ 4$ k.r.o., który stanowi: Jeżeli kobieta zaszła $w$ ciążę, jej mąż nie może żądać unieważnienia matżeństwa z powodu braku przepisanego wieku. 
przyczyny może każdy kto, ma w tym interes prawny. W tym miejscu należy zauważyć, iż takie same rozwiązania zawiera art. $16 \$ 2$ k.r.o., który stanowi, że: [u] nieważnienia małżeństwa z powodu pozostawania przez jednego z małżonków w poprzednio zawartym związku mał̇̇eńskim może żądać każdy, kto ma w tym interes prawny. Jako różnicę między rozwiązaniami Kodeksu rodzinnego i opiekuńczego a przepisami projektu o z.p. można wskazać to, iż projekt zakłada mniej rygorystyczne warunki unieważnienia związku partnerskiego z tego powodu, że jeden z partnerów pozostaje w poprzednio zawartym małżeństwie albo związku partnerskim niż te, które ustanawia Kodeks rodzinny i opiekuńczy dla małżeństw w przypadku bigamii. A mianowicie, brak jest przepisu analogicznego do art. $13 \$ 3$ k.r.o., który przewidywałby, że nie można unieważnić związku partnerskiego z powodu pozostawania przez jednego z partnerów w poprzednio zawartym związku małżeńskim lub partnerskim, jeżeli poprzedni związek ustał lub został unieważniony.

Pokrewieństwo I POWinowactwo Przeszkody pokrewieństwa oraz powinowactwa zostały uregulowane w projekcie o z.p. analogicznie jak w Kodeksie rodzinnym i opiekuńczym. Zarówno art. 5 ust. 1 zdanie pierwsze projektu, jak i art. $14 \$ 1$ zdanie pierwsze k.r.o. zakazują zawierania odpowiednio związków partnerskich oraz małżeństw pomiędzy krewnymi w linii prostej, rodzeństwem oraz powinowatymi w linii prostej. Ponadto art. 5 ust. 1 zdanie drugie identycznie tak jak art. $14 \$ 1$ zdanie drugie k.r.o. wskazuje, iż związek może zostać zawarty pomiędzy powinowatymi za zezwoleniem sądu, jeśli przemawiają za tym ważne powody. Niemniej zgodnie z art. 13 ust. 4 projektu o z.p. unieważnienia związku partnerskiego z powodu pokrewieństwa lub powinowactwa pomiędzy partnerami może żądać każdy, kto ma w tym interes prawny, natomiast w świetle art. $14 \$ 2-3$ k.r.o. unieważnienia małżeństwa $z$ powodu powinowactwa może żądać każdy z małżonków, a z powodu pokrewieństwa - każdy, kto ma w tym interes prawny.

WADY ośWiadczeń WOLI Projektowany art. 13 ust. 2 pkt 6 przyjmuje dla związków partnerskich rozwiązania zawarte w art. $15^{1} \$ 1$ pkt 2 i 3 k.r.o., który przewiduje, iż małżeństwo może być unieważnione, jeżeli oświadczenie o wstąpieniu w związek małżeński zostało złożone pod wpływem błędu co do tożsamości drugiej strony lub pod wpływem bezprawnej groźby drugiej strony lub osoby trzeciej, jeżeli z okoliczności wynika, że składający oświadczenie mógł się obawiać, iż jemu samemu lub innej osobie grozi poważne niebezpieczeństwo osobiste. Również art. 13 ust. 5 zdanie pierwsze projektu o z.p., przyznający legitymację do wytoczenia powództwa partnerowi, który złożył oświadczenie pod wpływem błędu lub bezprawnej groźby, powiela postanowienia art. $15 \$ 2$ k.r.o. Ponadto zdanie drugie art. 13 ust. 5 projektu o z.p., mówiące, że: [n]ie można żadać unieważnienia związk partnerskiego po upływie sześciu miesięcy od wykrycia błędu lub ustania obawy wywołanej groźba - a w każdym wypadku po upływie lat trzech od zawarcia partnerskiego, jest odpowiednikiem unormowań zawartych $\mathrm{w}$ art. $15^{1} \S 3$ k.r.o. 
Prima facie różnicą między przepisami Kodeksu rodzinnego i opiekuńczego a postanowieniami projektu jest to, że brak jest w nim odpowiednika art. $15^{1} \$ 1$ pkt 1 k.r.o., który przewidywałby możliwości unieważnienia związku partnerskiego, jeżeli oświadczenie o wstąpieniu w związek partnerski zostało złożone przez osobę, która z jakichkolwiek powodów znajdowała się w stanie wyłączającym świadome wyrażenie woli9. Jest to jednak tylko odmienność pozorna, bowiem w istocie podobne rozwiązanie zawiera art. 13 ust. 2 pkt 2 projektu o z.p., który stanowi: Związek partnerski może zostać unieważniony, jeśli decyzja o zawarciu związku nie została podjęta w sposób świadomy i swobodny.

CHOROBA PSYCHICZNA I NIEDOROZWój UMYsŁOWY W projekcie o z.p. brak jest przepisu, który wprost zakazywałby zawarcia związku partnerskiego osobie dotkniętej chorobą psychiczną albo niedorozwojem umysłowym, tak jak czyni to w stosunku do małżeństw art. $12 \$ 1$ k.r.o. Pomimo tego wydaje się jednak, że również przytoczony wyżej art. 13 ust. 2 pkt 2 projektu mógłby stanowić w większości przypadków podstawę unieważnienia związku partnerskiego, jeśli zostałby on zawarty przez osobę cierpiącą na chorobę psychiczną lub dotkniętą niedorozwojem umysłowym.

UbezwŁasnowolnienie Chociaż projekt o z.p. - inaczej niż Kodeks rodzinny i opiekuńczy - pomija przeszkodę ubezwłasnowolnienia całkowitego, to jednak biorąc pod uwagę art. $13 \$ 1$ k.c., który przewiduje, że: [o]soba, która ukończyła lat trzynaście, może być ubezwłasnowolniona całkowicie, jeżeli wskutek choroby psychicznej, niedorozwoju umysłowego albo innego rodzaju zaburzeń psychicznych, w szczególności pijaństwa lub narkomanii, nie jest w stanie kierować swym postępowaniem, należy przyjąć, że w istotnym zakresie ten brak mógłby eliminować art. 13 ust. 2 pkt 2 projektu.

ZaKaZ unieWAŻNienia zWIĄZKu po Jego ustaniu Kolejne łatwo dostrzegalne podobieństwa zawiera art. 13 ust. 6 projektu o z.p. oraz art. 18 k.r.o. Ten pierwszy wskazuje, że: nie można unieważnić związku partnerskiego po jego ustaniu. Nie dotyczy to jednak unieważnienia z powodu pokrewieństwa między partnerami oraz z powodu pozostawania przez jednego z partnerów $w$ chwili zawarcia małżństwa $w$ zawartym poprzednio związku partnerskim. Z kolei art. 18 k.r.o. stanowi: Nie można unieważnić matżeństwa po jego ustaniu. Nie dotyczy to jednak unieważnienia $z$ powodu pokrewieństwa między małżonkami oraz z powodu pozostawania przez jednego $z$ małżonków $w$ chwili zawarcia małżeństwa $w$ zawartym poprzednio związku małżeńskim.

Reasumując tę część analizy, należy stwierdzić, że regulacje dotyczące przesłanek unieważnienia małżeństwa oraz związku partnerskiego są analogiczne, różnią się tylko w szczegółach, jednak ich istota pozostaje taka sama.

9 Por. art. $15^{1} \$ 1$ pkt 1 k.r.o., który stanowi: Małżeństwo może być unieważnione, jeżeli oświadczenie o wstąpieniu $w$ związek małżeński lub oświadczenie przewidziane $w$ art. $1 \$ 2$ zostało złożone przez osobę, która z jakichkolwiek powodów znajdowała się $w$ stanie wyłączającym świadome wyrażenie woli. 


\section{- Nazwiska małżonków i partnerów}

Artykuł 7 ust. 9 projektu o z.p. przewiduje, że wraz z oświadczeniami o wstąpieniu w związek partnerski każdy z partnerów może złożyć oświadczenie o nazwisku, które będzie nosił po zawarciu związku. Zgodnie z tym przepisem wspólne nazwisko, jakie będą nosić partnerzy, może być dotychczasowym nazwiskiem jednego z nich lub połączeniem dotychczasowych nazwisk partnerów, z tym że nazwisko utworzone w wyniku połączenia nie może składać się z więcej niż dwóch członów. Z kolei art. $25 \$ 1$ k.r.o. stanowi, że: [o] nazwisku, które każdy $z$ małżonków będzie nosił po zawarciu małżeństwa, decyduje jego oświadczenie złożone przed kierownikiem urzędu stanu cywilnego. Oświadczenie może być złożone bezpośrednio po zawarciu małżeństwa albo przed sporządzeniem przez kierownika urzędu stanu cywilnego zaświadczenia stwierdzającego brak okoliczności wyłaczajacych zawarcie małżeństwa. W art. $25 \$ 2$ k.r.o. precyzuje się i stwierdza: Małżonkowie moga nosić wspólne nazwisko będace dotychczasowym nazwiskiem jednego $z$ nich. Każdy z małżonków może również zachować swoje dotychczasowe nazwisko albo połaczyć z nim dotychczasowe nazwisko drugiego małżonka. Nazwisko utworzone w wyniku połaczenia nie może składać się $z$ więcej niż dwóch członów.

Różnica pomiędzy przepisami Kodeksu rodzinnego i opiekuńczego a projektowanymi rozwiązaniami dla związków partnerskich jest nieznaczna. A mianowicie, $\mathrm{z}$ art. 7 ust. 9 projektu o z.p. wynika, że partner może złożyć oświadczenie o tym, iż: 1) będzie nosił swoje dotychczasowe nazwisko; 2) będzie nosił wspólne nazwisko będące dotychczasowym nazwiskiem jednego $\mathrm{z}$ nich lub połączeniem dotychczasowych nazwisk partnerów. Jako że przepis mówi o „wspólnym nazwisku, jakie będą nosić partnerzy”, należy przyjąć, iż w przypadku, o którym mowa w pkt 2, tym samym nazwiskiem dwuczłonowym musieliby posługiwać się obaj partnerzy. A zatem w świetle art. 7 ust. 9 - inaczej niż na gruncie Kodeksu rodzinnego i opiekuńczego - nie jest dopuszczalne, aby tylko jeden z partnerów nosił nazwisko dwuczłonowe składające się z jego dotychczasowego nazwiska i nazwiska drugiego partnera.

Mając na uwadze przepisy Kodeksu rodzinnego i opiekuńczego oraz projektowane rozwiązania, trzeba więc stwierdzić, że w analizowanym zakresie są one nie tylko podobne, ale niemalże identyczne.

\section{- Stosunki majątkowe}

Artykuł 14 ust. 1 projektu o z.p. przewiduje, że: [p]artnerzy moga ustanowić wspólność majątkowa poprzez zawarcie umowy w formie aktu notarialnego. Z kolei ust. 2 tego artykułu nakazuje do stosunków majątkowych między partnerami stosować odpowiednio przepisy tytułu I działu III rozdziału II Kodeksu rodzinnego i opiekuńczego dotyczące małżeńskich umownych ustrojów majątkowych. Wskazane przepisy projektu mogą budzić jednak wątpliwości interpretacyjne, dlatego na wstępie należy je wyjaśnić. 
Warto zauważyć, że art. 14 ust. 1, mówiąc o możliwości ustanowienia wspólności majątkowej poprzez zawarcie umowy w formie aktu notarialnego, sugeruje, iż chodzi o umowną wspólność majątkową. Jednak wydaje się, że projektodawcy chodziło o to, aby partnerzy mogli poprzez zawarcie umowy w formie aktu notarialnego uregulować między sobą stosunki majątkowe tak samo jak stosunki majątkowe małżonków regulują przepisy Kodeksu rodzinnego i opiekuńczego dotyczące ustawowej wspólności majątkowej. Stąd też dopiero w ust. 2 art. 14 nakazuje się do związków partnerskich odpowiednio stosować przepisy dotyczące małżeńskich umownych ustrojów majątkowych.

Mając powyższe na uwadze, należy uznać, że przyjęte w projekcie rozwiązania dopuszczają, aby stosunki majątkowe między partnerami były unormowane w ten sam sposób, jak między małżonkami, z tą różnicą, że ustrój będący odpowiednikiem małżeńskiej ustawowej wspólności majątkowej nie powstawałby między partnerami z mocy ustawy, lecz na podstawie umowy. Przy czym warto zauważyć, że brak regulacji kreujących wspólność majątkową między partnerami oznacza, iż w razie niezawarcia żadnej umowy ich stosunki majątkowe kształtowałyby się prawie tak samo jak w przypadku małżeńskiego ustroju rozdzielności majątkowej ${ }^{10}$. A więc, w istocie ustrój majątkowy, który - w razie niezawarcia umowy - dla małżonków jest obligatoryjny, dla partnerów byłby fakultatywny, zaś ten, który dla małżeństw jest fakultatywnym rozwiązaniem, w przypadku związków partnerskich byłby - w razie braku umowy majątkowej - rozwiązaniem obligatoryjnym.

Trzeba również dodać, że brak ustawowego ustroju wspólności majątkowej nie jest rozwiązaniem, które dostatecznie różnicuje związek partnerski od małżeństwa. Warto bowiem zauważyć, że np. w Portugalii wówczas, gdy małżeństwo jest zawierane przez osobę, która ukończyła 60 lat, z mocy ustawy powstaje ustrój rozdzielności majątkowej ${ }^{11}$, co nie oznacza przecież, iż związek ten różni się od małżeństwa zawieranego przez osoby młodsze na tyle, że należałoby go nazywać związkiem partnerskim.

\section{- Rozwiązanie małżeństwa i związku partnerskiego}

Zgodnie z art. $56 \$ 1$ k.r.o. pozytywną przesłanką rozwodu jest zupełny i trwały rozkład pożycia między małżonkami. W tym wypadku każdy z małżonków

10 Prawie tak samo, ponieważ projektodawcy nie zmieniają na art. $680^{1} \S 1$ k.c., który stanowi: Małżonkowie sq najemcami lokalu bez względu na istniejące między nimi stosunki majątkowe, jeżeli nawiązanie stosunku najmu lokalu mającego służyć zaspokojeniu potrzeb mieszkaniowych założonej przez nich rodziny nastąiło w czasie trwania małżeństwa. Jeżeli między małżonkami istnieje rozdzielność majątkowa albo rozdzielność majątkowa $z$ wyrównaniem dorobków do wspólności najmu stosuje się odpowiednio przepisy o wspólności ustawowej.

11 Art. 1720 ust. 1 lit. b portugalskiego kodeksu cywilnego (Código Civil) z 25 listopada 1966 r., http://www.pgdlisboa.pt/leis/lei_mostra_articulado.php?ficha=1\&artigo_id= \&nid=775\&pagina $=1 \&$ tabela $=$ leis\&nversao $=\&$ so_miolo $=$ [dostęp 20 czerwca 2018 r.] 
może żądać, aby sąd rozwiązał małżeństwo przez rozwód. Negatywne przesłanki rozwodu formułuje art. $56 \$ 2$ i 3 k.r.o. W świetle pierwszego z tych przepisów pomimo zupełnego i trwałego rozkładu pożycia rozwód nie jest dopuszczalny, jeżeli wskutek niego miałoby ucierpieć dobro wspólnych małoletnich dzieci małżonków albo jeżeli z innych względów orzeczenie rozwodu byłoby sprzeczne z zasadami współżycia społecznego. Z kolei art. $56 \$ 3$ k.r.o. przewiduje, że rozwód nie jest też dopuszczalny, jeżeli żąda go małżonek wyłącznie winny rozkładu pożycia, chyba że drugi małżonek wyrazi zgodę na rozwód albo że odmowa jego zgody na rozwód jest w danych okolicznościach sprzeczna z zasadami współżycia społecznego.

Natomiast w świetle projektowanych rozwiązań związek partnerski zostaje rozwiązany na skutek złożenia przed kierownikiem urzędu stanu cywilnego zgodnych oświadczeń woli o rozwiązaniu związku (art. 10 pkt 1 oraz art. 11 ust. 1 projektu o z.p.). Fakultatywnie oświadczenia te mogą być złożone przed konsulem (art. 11 ust. 3 projektu o z.p.). Jeżeli zaś jeden z partnerów nie wyraża zgody na zakończenie związku, drugi może żądać jego rozwiązania na drodze sądowej (art. 11 ust. 4 projektu o z.p.). Mając na uwadze art. 4 pkt 4 projektu przep.wprow.u.z.p., który zakłada dodanie do Kodeksu rodzinnego i opiekuńczego art. 61a nakazującego stosować przepisy działu IV Kodeksu rodzinnego i opiekuńczego odpowiednio do ustania związku partnerskiego, należy przyjąć, iż w razie braku porozumienia partner mógłby domagać się rozwiązania związku na podstawie art. 56 k.r.o., który określa przesłanki rozwodu.

Ponadto, jak przewiduje art. 12 ust. 1 projektu o z.p., jeżeli w trakcie trwania związku jeden z partnerów przysposobił dziecko drugiego partnera, ustanie związku partnerskiego może nastąpić przez jednoczesne złożenie zgodnych oświadczeń przez partnerów wyłącznie wtedy, gdy partnerzy zawrą pisemne porozumienie o sposobie wykonywania władzy rodzicielskiej i utrzymywaniu kontaktów z dzieckiem po rozwiązaniu związku partnerskiego, a sąd je zaakceptuje. Natomiast - jak dodaje ten przepis - w przypadku braku możliwości zawarcia porozumienia, by rozwiązać związek partnerski, każdy z partnerów ma prawo żądać, aby związek został rozwiązany przez sąd ${ }^{12}$.

Przedstawione porównanie pokazuje, że proponowane przesłanki rozwiązania związku partnerskiego są mniej rygorystyczne niż występujące w Kodeksie rodzinnym i opiekuńczym przesłanki rozwodu małżonków. Niemniej nie oznacza to, że możliwość rozwiązania związku na podstawie zgodnych oświadczeń woli sprawia, iż związek ten nie może być już uważany za związek małżeński. Rozwód na podstawie porozumienia małżonków występuje np. w Estonii ${ }^{13}$, Por-

12 Zob. niżej również uwagi szczegółowe na temat art. 12 projektu o z.p.

13 Zob. $\$ 64$ oraz $\$ 64^{1}$ estońskiego kodeksu prawa rodzinnego z 18 listopada 2009 r. Aktualna wersja kodeksu w języku estońskim wraz z tłumaczeniem na język angielski dostępne są na stronie internetowej oficjalnego publikatora aktów praw- 
tugalii ${ }^{14}$ oraz Rumunii ${ }^{15}$. Ponadto zgodna wola rozwiązania małżeństwa, pod warunkiem że małżonkowie nie utrzymują pożycia przez okres prawem oznaczony, może uzasadniać rozwód np. w Niemczech ${ }^{16}$ oraz Chile ${ }^{17}$.

\section{- Adopcja dzieci przez osoby będące w związku partnerskim}

Artykuł 17 ust. 1 projektu o z.w. stanowi, że: [p] artner może przysposobić zstępnego drugiego partnera, w pierwszym stopniu pokrewieństwa, na zasadach określonych w Tytule II Dziale II ustawy z dnia 25 litego 1964 - Kodeks rodzinny i opiekuńczy. Ponadto art. 17 ust. 2 przewiduje, że w razie: wyrażenia zgody przez partnera, którego zstępnego przysposobienia dotyczy oraz drugiego rodzica osoby przysposabianej posiadajacego pełnię władzy rodzicielskiej, przy braku sprzeciwu ze strony przysposabianego, sąd może odmówić przysposobienia jedynie $z$ ważnych przyczyn dotyczacych dobra przysposabianego. Jak dodaje ust. 3 tego artykułu, płeć partnera przysposabiającego nie może stanowić podstawy odmowy przysposobienia.

Może wydawać się, że projekty przewidują tylko możliwość przysposobienia zstępnego partnera, w pierwszym stopniu pokrewieństwa. Jednak uważna lektura art. 4 pkt 16 projektu przep.wprow.u.z.p. prowadzi do innych wniosków. Przepis ten zakłada dodanie do Kodeksu rodzinnego i opiekuńczego art. $127^{1}$ w następującym brzmieniu: Przepisy niniejszego Działu stosuje się odpowiednio do przysposobienia dziecka przez partnerów lub partnera $w$ ramach związku partnerskiego, w rozumieniu przepisów ustawy o związku $z$ partnerskim, $z$ zastrzeżeniem przepisów art. 14 ustawy o związku partnerskim. W zakresie, w jakim przepisy niniejszego Działu przewiduja prawa lub obowiązki wobec małżonków, stosuje się je odpowiednio do partnerów związku partnerskiego [wyróżnienie - R.D.] ${ }^{18}$.

Po pierwsze, należy wyjaśnić, że dział, do którego odsyła projektowany art. $127^{1}$ k.r.o., to dział regulujący kwestie związane $\mathrm{z}$ adopcją dziecka. Po drugie,

nych Riigi Teataja: https://www.riigiteataja.ee/en/eli/ee/503042014005/consolide/ current\#659e8667-21b4-4357-940f-c379e23ff67d [dostęp 20 czerwca 2018 r.].

14 Zob. art. 1773 ust. 1-2 portugalskiego kodeksu cywilnego z 25 listopada 1966 r., http://www.pgdlisboa.pt/leis/lei_mostra_articulado.php?ficha=1\&artigo_id=\&nid=7 75\&pagina $=1 \&$ tabela $=$ leis\&nversao=\&so_miolo $=$ [dostęp 20 czerwca 2018 r.].

15 Zob. art. 373 ust. 1 rumuńskiego kodeksu cywilnego z 17 lipca 2009 r. Kodeks w języku rumuńskim dostępny na stronie portalu legislacyjnego Legislativ: http://legislatie. just.ro/Public/DetaliiDocument/109884\#id_crtA139_ttl [dostęp 20 czerwca 2018 r.].

16 Zob. $\$ 1566$ ust. 1 niemieckiego kodeksu cywilnego z 1896 r., http://www.gesetze-im-internet.de/bgb/index.html [dostęp 20 czerwca 2018 r.].

17 Zob. art. 55 ustawy nr 19947 o małżeństwie cywilnym (Ley núm. 19.947, Nueva Ley de matrimonio civil), https://www.leychile.cl/Navegar?idNorma=225128 [dostęp 20.06.2018 r.]; M. Tapia Rodríguez, El divorcio en el derecho chileno [w:] El divorcio en el derecho iberoamericano, red. Á. Acedo Penco, L.B. Pérez Gallardo, Bogota, Meksyk, Madryd, Buenos Aires 2009, s. 149-151.

18 Zob. niżej uwagi szczegółowe do art. 4 pkt 16 projektu przep.wprow.u.z.p. 
trzeba zauważyć, że art. $127^{1}$ nie tylko wskazuje, iż przepisy tego działu stosuje się odpowiednio do przysposobienia dziecka przez partnera, ale także przewiduje ich odpowiednie stosowanie w przypadku adopcji dziecka przez obu partnerów. Ponieważ projektowany art. $127^{1}$ posługuje się liczbą mnogą "partnerzy”, należy przyjąć, że nie odnosi się on tylko do dopuszczonej przez art. 17 projektu o z.w. możliwości przysposobienia dziecka jednego z partnerów przez drugiego partnera, lecz dopuszcza także, by adoptowali oni wspólnie dzieci, które nie są zstępnymi jednego $z$ nich.

W związku z powyższym w konkluzji trzeba stwierdzić, że projektowane regulacje $\mathrm{w}$ zakresie dotyczącym przysposobienia zrównują prawa i obowiązki partnerów oraz małżonków. Ponadto - mając na uwadze, że w świetle art. 2 projektu o z.w. związek partnerski mógłby być zawarty przez pary jednopłciowe - należy dodać, że wskazane jest, by projektowane regulacje dotyczące adopcji dzieci zostały zaopiniowane przez ekspertów z innych nauk społecznych, zwłaszcza przez specjalistów z dziedziny psychologii. W szczególności należałoby wyjaśnić, w jaki sposób wychowanie przez pary homoseksualne wpływa na rozwój dziecka. Odpowiedź udzielona przez osoby specjalizujące się w innych, nieprawniczych dziedzinach wiedzy nie może pozostać bez znaczenia dla oceny prawnej dopuszczalności wprowadzenia proponowanych regulacji. Ochrona dobra dziecka jest bowiem zasadą konstytucyjną ${ }^{19}$, która jest realizowana przez liczne postanowienia Kodeksu rodzinnego i opiekuńczego, a w szczególności przez te dotyczące przysposobienia ${ }^{20}$.

\section{Konkluzja}

Przedstawiona wyżej analiza porównawcza prowadzi do wniosku, że projektowane rozwiązania dotyczące związków partnerskich są analogiczne, w wysokim stopniu zbliżone do tych zawartych w obowiązujących przepisach odnoszących się do małżeństw. Co więcej, w wielu miejscach są one takie same albo prawie identyczne. Należy również dodać, iż projekt przep.wprow.u.z.p. modyfikuje obowiązujące przepisy w ten sposób, aby regulacje dotyczące małżonków miały zastosowanie także do partnerów tworzących związek partnerski. Prawie wszystkie zaproponowane tam zmiany polegają na dodaniu zwrotu „związek partnerski w rozumieniu ustawy o związku partnerskim", w formie adekwatnej do treści obowiązującego przepisu oraz wprowadzeniu regulacji, które nakazują odpowiednie stosowanie do związków partnerskich przepisów dotyczących małżeństwa. Ten obszerny projekt mógłby niemalże w całości zostać zastąpiony przez dodanie do projektu o z.p. takich rozwiązań, które przewidywałyby, że ilekroć w odrębnej ustawie jest mowa o małżeństwie lub małżonku należy przez to także

19 Zob. w szczególności art. 72 Konstytucji.

20 Zob. zwłaszcza art. 114 k.r.o., który przewiduje, że przysposobić można małoletniego tylko dla jego dobra. 
rozumieć odpowiednio związek partnerski lub partnera w rozumieniu ustawy o związku partnerskim.

Mając powyższe na uwadze, należy stwierdzić, że opiniowane projekty ustaw wbrew stosowanemu w nich nazewnictwu - nie wprowadzają instytucji związku partnerskiego, lecz ustanawiają instytucję małżeństwa jednopłciowego, a przez to mogą być uznane za niezgodne $\mathrm{z}$ art. 18 Konstytucji.

Bynajmniej konkluzji tej nie przeczą drobne różnice występujące między obowiązującymi przepisami prawa małżeńskiego a regulacją przeznaczoną dla związków partnerskich. Należy bowiem zauważyć, że jeśli nie we wszystkich, to przynajmniej w większości państw na świecie obowiązują inne niż w Polsce unormowania dotyczące małżeństwa, nie oznacza to jednak, iż związki zawarte według obcego prawa nie mogą być uznawane za małżeństwa. Dobitnie świadczą o tym regulacje ustawy z 4 lutego 2011 r. - Prawo prywatne międzynarodowe, które pozwalają stosować $\mathrm{w}$ sprawach małżeńskich powiązanych $\mathrm{z}$ systemami prawnymi innych państw - prawo obce ${ }^{21}$.

Jednocześnie należy wskazać, że nawet gdyby projektodawca zdecydował się wyeliminować z projektów przepisy pozwalające na zawieranie związków partnerskich przez osoby tej samej płci, to i tak ocena dotycząca (nie)konstytucyjności proponowanych regulacji pozostałaby taka sama, ponieważ związek mężczyzny i kobiety niebędący małżeństwem nie może pozostawać pod opieką i ochroną, która jest przewidziana dla małżeństw ${ }^{22}$.

\section{Uwagi szczegółowe}

SKUTKi UNIEWAŻNiENIA ZWIĄZKU PARTNERSKIEGo Mimo że projekt o z.p. określa przesłanki unieważnienia związku partnerskiego, to w żadnym z opiniowanych projektów nie ma rozwiązań, które pozwalałyby ustalić, jakie skutki powoduje unieważnienie w zakresie stosunku partnerów do wspólnych dzieci oraz w zakresie stosunków majątkowych między partnerami. Ponadto projekty nie rozstrzygają o tym, czy w przypadku unieważnienia związku partnerskiego sąd orzeka także, czy i który z partnerów zawarł związek w złej wierze (por. art. 20 k.r.o.).

Art. 1 Projektu o z.w. Przepis ten stanowi, że: [u] stawa określa zasady zawierania i ustania związk partnerskiego, wzajemne prawa i obowiązki partnerów oraz stosunki majątkowe pomiędzy partnerami. Należy jednak zauważyć, iż art. 17 tegoż projektu reguluje kwestie związane z przysposobieniem przez partnera zstępnych drugiego partnera. W związku z tym, że przysposobienie wywołuje

${ }^{21}$ Zob. w szczególności art. 48-54 tej ustawy. Wyjątek od stosowania prawa obcego wprowadza art. 7 ustawy - Prawo prywatne międzynarodowe, który stanowi, że: [p] rawa obcego nie stosuje sie, jeżeli jego stosowanie miałoby skutki sprzeczne z podstawowymi zasadami porzadku prawnego Rzeczypospolitej Polskiej.

22 Por. W. Borysiak, Komentarz do art. 18, op. cit., nb 129. 
przede wszystkim skutki prawne między przysposabiającym i przysposobionym, a nie między partnerami, należy stwierdzić, iż przedmiot ustawy został $\mathrm{w}$ art. 1 projektu błędnie określony.

ART. 3 UST. 1 PROJEKTU O z.w. Stanowi on, że: [p] rzez zawarcie zwiazku partnerskiego partnerzy zobowiązuja się do pozostawania we wspólnym pożyciu, obejmującym wzajemny szacunek $i$ wspieranie. Trzeba w tym miejscu zauważyć, że proponowane rozwiązanie sprowadza wspólne pożycie do wzajemnego szacunku i wspierania się. W świetle treści przepisu bynajmniej nie można uznać, że wzajemny szacunek i wspieranie się są tylko przykładami elementów konstytuujących wspólne pożycie, bowiem gdyby tak było, to art. 3 ust. 1 posługiwałby się zwrotem „w szczególności”.

Natomiast - jak wskazuje się w piśmiennictwie prawniczym oraz orzecznictwie - wspólne pożycie polega na duchowej, fizycznej i gospodarczej więzi i powinno ono bazować na uczuciu miłości, lojalności i szczerości, wzajemnych stosunkach intymnych i prowadzeniu wspólnego gospodarstwa domowego ${ }^{23} . \mathrm{Na}$ tle powyższego stanowiska trzeba stwierdzić, że art. 3 ust. $1 \mathrm{w}$ istotny sposób redukuje pojęcie „wspólnego pożycia” i dlatego należałoby go zmodyfikować.

Ponadto, mając na uwadze treść oświadczenia o wstąpieniu w związek partnerski, w którym partner przyrzeka, że uczyni wszystko, aby związek był zgodny, szczęśliwy i trwały (zob. art. 7 ust. 5 projektu o z.w.), wątpliwości budzi brak przepisu, który formułowałby prawny obowiązek wierności oraz współdziałania dla dobra zawartego związku. Chociaż naruszenie tych obowiązków nie wiązałoby się z żadną bezpośrednią sankcją, to jednak stanowiłoby wyznacznik pozwalający orzekać o winie rozkładu pożycia w przypadku rozwiązania związku partnerskiego na drodze sądowej (zob. art. 11 ust. 4 projektu o z.p. oraz art. 56 k.r.o. w związku z art. 4 pkt 4 projektu przep.wprow.u.z.p.).

ART. 9 UST. 2 PROJeKTU o z.P. Należy przypuszczać, że w przepisie tym błędnie odwołano się do art. 6 ust. 4 i 8 projektu o z.p., bowiem art. 6 nie jest podzielony na ustępy. Uwzględniając sens regulacji, można wnosić, że projektodawcy chodziło o art. 7 ust. 4 i 8 projektu o z.p.

ART. 12 PROjeKtu o Z.W. [Nierówne traktowanie WSPÓLNYCH DZieci PARTNERÓW I DZIECI PRZYSPOSOBIONYCH] W świetle art. 12 ust. 1, w przypadku

23 Zob. np. K. Gromek, Kodeks rodzinny i opiekuńczy. Komentarz, Warszawa 2018, komentarz do art. 23, nb 2; J. Gajda, Komentarz do art. 23 [w:] Kodeks rodzinny i opiekuńczy. Komentarz, red. K. Pietrzykowski, Warszawa 2018, nb 12; uchwała SN z 28 maja 1955 r., sygn. akt I CO 5/55, OSNCK 1955, nr 3, poz. 46, w której stwierdza się, że: pożycie małżeńskie wyraża się w szczególnego rodzaju wspólnocie duchowej, fizycznej i gospodarczej; wyrok SN z 22 października 1999 r., sygn. akt III CKN 386/98, Legalis $\mathrm{nr}$ 342590, gdzie stwierdza się: zgodnie $z$ utrwalonym $w$ orzecznictwie pogladem, nie kwestionowanym $w$ doktrynie, wspólne pożycie $w$ rozumieniu art. 23 k.r.o. polega na duchowej, fizycznej oraz gospodarczej więzi matżonków, stanowiącej cel matżeństwa i umożliwiajaccej realizacje jego podstawowych zadań. 
gdy w trakcie trwania związku jeden z partnerów przysposobił dziecko drugiego partnera, ustanie związku partnerskiego może nastąpić przez jednoczesne złożenie zgodnych oświadczeń przez partnerów wyłącznie wtedy, gdy partnerzy zawrą pisemne porozumienie o sposobie wykonywania władzy rodzicielskiej i utrzymywaniu kontaktów z dzieckiem po rozwiązaniu związku partnerskiego, a sąd je zaakceptuje. Natomiast - jak dodaje ten przepis - w razie braku możliwości zawarcia porozumienia, by rozwiązać związek partnerski, każdy z partnerów ma prawo żądać, aby związek został rozwiązany przez sąd.

Przedstawione rozwiązanie budzi istotne zastrzeżenia i wskazuje na brak spójności aksjologicznej projektowanych regulacji, ponieważ ogranicza dopuszczalność rozwiązania związku przez złożenie zgodnych oświadczeń tylko do takich sytuacji, gdy między partnerami brak jest porozumienia o sposobie wykonywania władzy rodzicielskiej z dzieckiem przysposobionym. Należy jednak zwrócić uwagę, iż związki partnerskie - zgodnie z art. 2 projektu o z.w. mogłyby być zawierane przez osoby różnej płci, a ponadto art. 4 pkt 6 projektu przep. wprow.u.z.p. - zmieniając art. 62 k.r.o. - wprowadzałby domniemanie pochodzenia dziecka od partnera matki. Dlatego dopuszczalność rozwiązania związku partnerskiego na podstawie zgodnego oświadczenia w razie braku porozumienia o sposobie wykonywania władzy rodzicielskiej i utrzymywaniu kontaktów ze wspólnym dzieckiem partnerów jest niezrozumiałe.

Zresztą, co należy też podkreślić, nawet w sytuacji, gdy partnerzy „rozwodzący się" na podstawie zgodnych oświadczeń woli przygotowaliby pisemne porozumienie dotyczące wykonywania władzy rodzicielskiej i utrzymywania kontaktów z ich wspólnym dzieckiem, to w świetle projektowanych rozwiązań nie musiałoby ono zostać zatwierdzone przez sąd ani innych organ, bowiem art. 12 ust. 2, który mówi o warunkach uwzględnienia tego rodzaju porozumienia, odnosi się do sądowego trybu rozwiązania związku partnerskiego, o czym świadczy to, że rozpoczyna się on od słów: „W wyroku orzekającym rozwiązanie związku partnerskiego...”.

Mając powyższe na uwadze, należy dojść do wniosku, że projektowane rozwiązania zapewniają słabszą ochronę wspólnym dzieciom partnerów niż dzieciom jednego $\mathrm{z}$ nich przysposobionym przez drugiego, co jest niezgodne $\mathrm{z}$ konstytucyjną zasadą równości.

ART. 13 UST. 6 PROJEKTU O Z.W. I ART. 4 PKT 2 PROJEKTU PRZEP.WPROW.U.Z.P. Warto zauważyć, że art. 13 ust. 6 projektu o z.w. omyłkowo mówi, iż zakaz unieważnienia związku po jego ustaniu nie dotyczy unieważnienia: $z$ powodu pozostawania przez jednego $z$ partnerów $w$ chwili zawarcia małżeństwa $w$ zawartym poprzednio związu partnerskim, jak zaś można przypuszczać powinno być: w chwili zawarcia związku partnerskiego.

Poza tym, skoro przepis ten przewiduje, że ustanawiany w nim zakaz nie dotyczy unieważnienia $\mathrm{z}$ powodu pozostawania przez jednego z partnerów w poprzednio zawartym związku partnerskim, to tym bardziej powinien wyłączać 
stosowanie zakazu unieważnienia związku po jego ustaniu wówczas, gdy jeden $\mathrm{z}$ partnerów pozostawał w uprzednio zawartym małżeństwie.

Wobec tego, że art. 13 ust. 6 zdanie pierwsze projektu o z.p. przewiduje, że: [n] ie można unieważnić zwiąku partnerskiego po jego ustaniu, zbędne jest powielanie tego zapisu w art. 18 zdanie pierwsze k.r.o., który - zgodnie z art. 4 pkt 2 projektu przep.wprow.u.z. - po nowelizacji miałby stanowić: Nie można unieważnić małżeństwa lub zwiąku partnerskim w rozumieniu przepisów ustawy o zwiąku partnerskim, po ich ustaniu ${ }^{24}$.

Na marginesie warto dodać, że w projekcie art. 18 zdanie pierwsze k.r.o. występuje błąd. Zamiast „Związku partnerskim” winno być „Związku partnerskiego”. $\mathrm{Z}$ kolei w art. 13 ust. 6 brak jest kropki na końcu zdania.

ART. 4 PKT 5 PROJEKTU PRZEP.WPROW.U.Z.P. [DOMNIEMANIE POCHODZENIA DZIECKA] Artykuł 4 pkt 6 projektu przep.wprow.u.z.p. zakłada zmianę art. $62 \$ 1$ i 2 k.r.o. W świetle projektu art. $62 \$ 1$ uzyskałby następujące brzmienie: Jeżeli dziecko urodziło się $w$ czasie trwania małżeństwa albo związu partnerskiego, albo przed uplywem trzystu dni od ich ustania lub unieważnienia, domniemywa się, że pochodzi ono od męża albo partnera matki. Domniemania tego nie stosuje się, jeżeli dziecko urodziło się po uplywie trzystu dni od orzeczenia separacji. Z kolei art. $62 \$ 2$ proponuje się nadać następującą treść: Jeżeli dziecko urodzito się przed uplywem trzystu dni od ustania lub unieważnienie matżeństwa albo związku partnerskiego, lecz po zawarciu przez matkę drugiego małżeństwa albo zwiazku partnerskiego, domniemywa się, że pochodzi ono od drugiego męża albo partnera. Domniemanie to nie dotyczy przypadku, gdy dziecko urodziło się $w$ następstwie procedury medycznie wspomaganej prokreacji, na która wyrazit zgodę pierwszy mąż matki albo partner.

Na tle tych przepisów warto zwrócić uwagę, że art. 2 pkt 2 projektu o z.p. przewiduje, iż partnerem jest osoba fizyczna pozostająca w związku partnerskim, niezależnie od jej płci. W związku z tym użycie w art. $62 \$ 1$ i 2 k.r.o. rzeczownika rodzaju męskiego „partner” nie wyklucza stosowania zawartych tam domniemań ojcostwa w stosunku do kobiety będącej w związku partnerskim z matką dziecka. Innymi słowy, należy stwierdzić, że projektowane przepisy stwarzają możliwość zafałszowania rzeczywistości biologicznej i uznania kobiety za ojca dziecka.

ART. 4 PKT 16 PROJeKTU PRZEP.WPROW.U.z.P. Przepis ten zakłada dodanie do Kodeksu rodzinnego i opiekuńczego art. $127^{1} \mathrm{w}$ następującym brzmieniu: Przepisy niniejszego Działu stosuje się odpowiednio do przysposobienia dziecka przez partnerów lub partnera $w$ ramach związku partnerskiego, $w$ rozumieniu przepisów ustawy o związku z partnerskim, z zastrzeżeniem przepisów art. 14 ustawy o zwiazku partnerskim. W zakresie, w jakim przepisy niniejszego Działu przewiduja prawa lub obowiązki wobec małżonków, stosuje się je odpowiednio do partnerów związku partnerskiego. Biorąc pod uwagę, że w art. 14 projektu o z.p. jest

${ }^{24}$ Zob. art. 4 pkt 2 projektu przep.wprow.u.z.p. 
mowa o ustrojach majątkowych, należy przypuszczać, iż projektodawcy chodziło $\mathrm{o}$ art. 17 projektu o z.p., który reguluje kwestie związane z przysposobieniem.

ART. 5 PKT 2 PROJEKTU PRZEP.WPROW.U.Z.P. W przepisie tym proponuje się zmianę art. $43^{8} \$ 1$ k.c., który po nowelizacji miałby otrzymać następujące brzmienie: W przypadku utraty członkostwa przez wspólnika, którego nazwisko było umieszczone w firmie, spółka może zachować w swej firmie nazwisko byłego wspólnika tylko za wyrażona na piśmie jego zgoda, a w razie jego śmierci - za zgoda jego małżonka albo partnera $w$ rozumieniu przepisów ustawy o związku partnerskim, a także zgody jego dzieci. Wydaje się, iż powinno być: a także po uzyskaniu zgody jego dzieci albo a także za zgoda jego dzieci.

ArT. 5 PKT 11 PROJEKTU PRZEP.WPROW.U.Z.P. Przepis ten nie przewiduje żadnej zmiany, lecz powtarza treść obowiązującego art. 936 k.c.

ART. 5 PKT 12 PROJEKTU PRZEP.WPROW.U.Z.P. Przepis ten stanowi, że: art. 937 otrzymuje brzmienie: „Art. 939 (...)”. Oznaczenie art. 937 k.c. numerem 939 jest w sposób oczywisty niezgodne z zasadami techniki prawodawczej.

ART. 5 PKT 13 PROJEKTU PRZEP.WPROW.U.Z.P. W przepisie tym proponuje się nowelizację art. 940 k.c. Paragraf 2 tego artykułu miałby stanowić, że: [w]yłączenie małżonka od dziedziczenia następuje na mocy orzeczenia sąu. Wyłaczenia może żadać każdy z pozostałych spadkobierców ustawowych powołanych do dziedziczenia $w$ zbiegu z małżonkiem albo partnerem; termin do wytoczenia powództwa wynosi sześć miesięcy od dnia, w którym spadkobierca dowiedział się o otwarciu spadku, nie więcej jednak niż jeden rok od otwarcia spadku.

Biorąc pod uwagę, że art. 5 pkt 12 projektu przep.wprow.u.z.p. zmienia także $\$ 1$ art. 940 k.c. i przewiduje wyłączenie partnera od dziedziczenia, jeżeli spadkodawca wystąpił o rozwiązanie związku partnerskiego, w toku ewentualnych prac legislacyjnych należałoby wyjaśnić, dlaczego w zdaniu pierwszym proponowanego art. $940 \$ 1$ k.c. jest mowa tylko o wyłączeniu małżonka.

ART. 6 PKT 10 PROJEKTU PRZEP.WPROW.U.Z.P. Przepis ten przewiduje, że: $w$ Tytule VII, Dział I dodaje się Rozdział 4 brzmieniu: „Sprawy z zakresu związków partnerskich $w$ rozumieniu przepisów ustawy o związku partnerskim”. Oprócz tego, że brak jest litery „w” pomiędzy cyfrą „4” a wyrazem „brzmieniu”, należy przede wszystkim zauważyć, że przepis ten ani żaden inny nie określa, jaka miałaby być treść tego rozdziału.

ArT. 106 PROJEKTU PRZEP.WPROw.U.Z.P. Ponieważ projektowana regulacja zakłada nowelizację ustawy z 27 lipca 2005 r. - Prawo o szkolnictwie wyższym (t.j. Dz.U. 2017, poz. 2183, ze zm.), warto mieć na uwadze to, że w parlamencie toczą się prace nad reformą systemu szkolnictwa wyższego ${ }^{25}$. Zgodnie $\mathrm{z}$ art. 165 pkt 3 rządowego projektu ustawy - Przepisy wprowadzające ustawę - Prawo

25 Zob. rządowy projekt ustawy - Prawo o szkolnictwie wyższym i nauce (druk sejmowy nr 2446) oraz rządowy projekt ustawy - Przepisy wprowadzające ustawę - Prawo o szkolnictwie wyższym i nauce (druk sejmowy nr 2447). 
o szkolnictwie wyższym i nauce z dniem wejścia w życie tej ustawy obowiązujące Prawo o szkolnictwie wyższym utraci moc z wyjątkiem: a) art. 112a, który utraci moc z dniem 1 czerwca 2018 r., b) oraz art. 98, art. 100, art. 101, art. 102, art. 103, art. 103a, art. 104 i art. 106, które utracą moc z dniem 31 grudnia 2018 r. W związku z powyższym w toku ewentualnych prac nad opiniowanym projektem należałoby uwzględnić wyniki procesu legislacyjnego w zakresie dotyczącym szkolnictwa wyższego.

\section{Podsumowanie}

- Projektowane przepisy - wbrew stosowanemu w nich nazewnictwu - wprowadzają instytucję małżeństwa jednopłciowego i dlatego mogą zostać uznane za niezgodne $\mathrm{z}$ art. 18 Konstytucji.

- Ponieważ projekty dopuszczają adopcję dzieci przez pary homoseksualne, wskazane jest, by rozwiązanie to zostało zaopiniowane również przez ekspertów z innych nauk społecznych, zwłaszcza przez specjalistów z dziedziny psychologii. W szczególności powinni oni wszechstronnie ocenić, czy proponowane rozwiązania nie zagrażają prawidłowemu rozwojowi adoptowanego dziecka i nie sprzeciwiają się jego dobru.

- Artykuł 4 pkt 5 projektu ustawy - Przepisy wprowadzające ustawę o związku partnerskim w związku z art. 2 pkt 2 projektu ustawy o związku partnerskim stwarza możliwość zafałszowania rzeczywistości biologicznej i dopuszcza uznanie kobiety za ojca dziecka.

- Projektowane regulacje dotyczące rozwiązania związku partnerskiego zapewniają słabszą ochronę wspólnym dzieciom partnerów niż dzieciom jednego $\mathrm{z}$ nich przysposobionym przez drugiego, co jest niezgodne $\mathrm{z}$ konstytucyjną zasadą równości.

- Projekty zawierają inne istotne - choć nie tak doniosłe jak te wskazane wyżej mankamenty. W szczególności zaś w projekcie ustawy o związku partnerskim błędnie określono jej przedmiot, istotnie zredukowano pojęcie wspólnego pożycia oraz nie uregulowano skutków unieważnienia związku partnerskiego. Z kolei w drugim z opiniowanych projektów występują błędy redakcyjne, które w razie jego uchwalenia w tej formie miałyby daleko idące negatywne skutki.

\section{Bibliografia}

Borysiak W., Komentarz do art. 18 [w:] Konstytucja RP, t. I, Komentarz. Art. 1-86, red. M. Safjan, L. Bosek, Warszawa 2016.

Gajda J., Komentarz do art. 23 [w:] Kodeks rodzinny i opiekuńczy. Komentarz, red. K. Pietrzykowski, Warszawa 2018. 
Garlicki L., Komentarz do art. 18 [w:] Konstytucja Rzeczypospolitej Polskiej. Komentarz, t. I, red. L. Garlicki, M. Zubik, Warszawa 2016.

K. Gromek, Kodeks rodzinny i opiekuńczy. Komentarz, Warszawa 2018.

Tapia Rodríguez M., El divorcio en el derecho chileno [w:] El divorcio en el derecho iberoamericano, red. Á. Acedo Penco, L.B. Pérez Gallardo, Bogota-Meksyk-MadrydBuenos Aires 2009. 


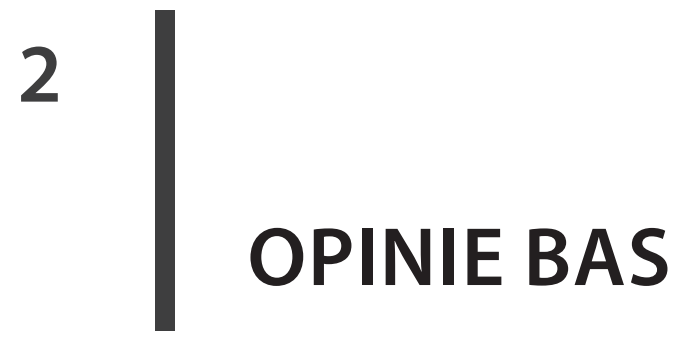

D

SPRAWY POSELSKIE 



\section{Termin przedawnienia prawa do odprawy emerytalnej przysługującej na podstawie art. 38 ustawy o wykonywaniu mandatu posła i senatora ${ }^{1}$}

Limitation period for the right to retirement gratuity mentioned in Article 38 of the Act on the Exercise of the Mandate of a Deputy or Senator (WAP-1036/18): Members of Parliament remain in a nonlabour the so-called systemic employment, which is not regulated by law in a precise manner. The nature of the retirement gratuity entitled under the aforementioned provision of the Act is not clear. There is a possible interpretation, according to which that this gratuity is not a subject to a limitation period of 3 years (pursuant to Article $291 \S 1$ of the Labour Code), but to a 10-year period specified in Article 118 of the Civil Code. However the author claims that the 3-year limitation period provided in labour law is applicable in the discussed situation.

Keywords: pensions and annuities, Deputy, limitation of claims

Słowa kluczowe: emerytury i renty, poseł, przedawnienie roszczeń

Ekspert ds. legislacji BAS; irena.galinska-raczy@sejm.gov.pl.

\section{Przedmiot opinii}

Opinia dotyczy kwestii związanej z zachowaniem uprawnienia do odprawy emerytalnej w następującym stanie faktycznym. W 2009 r. i 2010 r. dwaj posłowie zawodowi, przeszli na emeryturę i nie otrzymali odpraw emerytalnych przysługujących na podstawie art. 38 ustawy z 9 maja 1996 r. o wykonywaniu mandatu posła i senatora ( $\mathrm{z}$ informacji uzyskanych w Biurze Obsługi Posłów wynika, że mimo poinformowania ich o możliwości uzyskania odprawy nie ubiegali się o to świadczenie). Postawiono pytanie, czy w takiej sytuacji prawo do odprawy uległo

1 Opinia prawna na temat terminu przedawnienia prawa do odprawy emerytalnej przystugujacej na podstawie art. 38 ustawy z dnia 9 maja 1996 r. o wykonywaniu mandatu posła i senatora (we wskazanym stanie faktycznym) sporządzona 14 czerwca $2018 \mathrm{r}$. na zlecenie posłów Klubu Parlamentarnego Platforma Obywatelska; BAS-WAP 1036/18. 
przedawnieniu oraz czy mogą o nią wystąpić na koniec obecnej kadencji Sejmu (zwłaszcza z uwagi na art. 40 tej ustawy).

Jednocześnie zwrócono się o wyjaśnienie, jaki jest tryb wypłaty odprawy, w tym czy jest ona wypłacana automatycznie, czy też należy o nią wystąpić.

Opinia została sporządzona $\mathrm{z}$ uwzględnieniem następujących aktów prawnych:

- ustawa z 9 maja 1996 r. o wykonywaniu mandatu posła i senatora, t.j. Dz.U. 2016, poz. 1510, ze zm.; dalej: u.w.m.p.s.,

- ustawa z 17 grudnia 1998 r. o emeryturach i rentach z Funduszu Ubezpieczeń Społecznych, t.j. Dz.U. 2017, poz. 1383, ze zm.,

- ustawa z 26 czerwca 1974 r. - Kodeks pracy, t.j. Dz.U. 2018, poz. 917, ze zm.; dalej: k.p.,

- ustawa z 23 kwietnia 1964 r. - Kodeks cywilny, t.j. Dz.U. 2017, poz. 459, ze zm.; dalej: k.c.

\section{Uzasadnienie}

1. Zgodnie $\mathrm{z}$ art. 38 ust. 1 u.w.m.p.s.: Posłowi $i$ senatorowi, który $w$ trakcie sprawowania mandatu lub w ciagu dwunastu miesięcy po jego wygaśnięciu albo dwóch lat od zakończenia korzystania $z$ urlopu bezpłatnego, o którym mowa w art. 29 $i$ art. 30, przechodzi na emeryture albo rente, przysługuje jednorazowa odprawa $w$ wysokości trzech uposażeń - przy przejściu na emeryturę oraz jednego uposażenia - przy przejściu na rentę.

Ani ustawa o wykonywaniu mandatu posła i senatora, ani przepisy wykonawcze do tego aktu nie określają trybu wypłaty odprawy wskazanej w powołanym przepisie, nie ma też ustalonego wzoru wniosku o wypłatę, który precyzowałby datę i okoliczności przejścia na emeryturę lub rentę (w tym np. w postaci deklaracji co do tego, czy poseł nie otrzymał odprawy emerytalnej u pracodawcy, co ma znaczenie z punktu widzenia art. 38 ust. 2 u.w.m.p.s. ${ }^{2}$, bowiem w sytuacji, kiedy otrzymałby odprawę u pracodawcy, nie miałby prawa do odprawy w Sejmie ${ }^{3}$ ). Brak takich uregulowań jest pewnym mankamentem, ale podobna sytuacja ma miejsce w przypadku pracowników podlegających powszechnemu prawu pracy, którzy nabywają prawo do odprawy emerytalno-rentowej czy nagród jubileuszowych i nie muszą składać wniosków o ich wypłatę, ale są zobowiązani dostarczyć

2 Przepis ten stanowi, że: [w] razie zbiegu uprawnień, z różnych tytułów, do jednorazowej odprawy $w$ związku z przejściem na emeryturę lub rentę, przysługuje odprawa wybrana przez uprawnionego.

3 W ten sposób jest interpretowany ten przepis przez J. Stelinę w komentarzu do art. 38 u.w.m.p.s., [w:] K. Grajewski, J. Stelina, P. Uziębło, Komentarz do ustawy o wykonywaniu mandatu posła i senatora, Warszawa 2014, s. 456. 
informacje i dokumenty umożliwiające pracodawcy ustalenie, że danej osobie przysługuje takie świadczenie ${ }^{4}$.

Wniosek taki jest konieczny, ponieważ właściwa w tej mierze jednostka organizacyjna Kancelarii Sejmu musi zostać poinformowana o fakcie „przejścia” na emeryturę i dacie tego przejścia, co ma znaczenie zwłaszcza w przypadku tzw. posłów niezawodowych (czyli niepobierających uposażenia poselskiego), którzy nie informują Kancelarii Sejmu o swoim statusie zawodowym, ani jego zmianie, tak jak ma to miejsce w przypadku posłów zawodowych ${ }^{5}$. Wypłata odprawy emerytalnej na podstawie art. 38 ust. 1 u.w.m.p.s. nie może odbywać się zatem w sposób automatyczny, tak jak ma to miejsce w przypadku odprawy parlamentarnej, która jest wypłacana wszystkim posłom, pod warunkiem że nie zostali wybrani na następną kadencję Sejmu oraz nie otrzymali w danej kadencji odprawy emerytalnej lub rentowej. Kancelaria Sejmu ma pełną wiedzę o spełnieniu tych warunków i nie musi zwracać się do posłów o ich potwierdzenie.

2. W art. 38 ust. 1 u.w.m.p.s. zostały ustalone dwie przesłanki nabycia prawa do odprawy:

- fakt „przejścia” na emeryturę (rentę) oraz

- czas (moment), w którym to przejście następuje.

Przez określenie "przejście na emeryturę" należy rozumieć nie tylko nabycie uprawnień emerytalnych (w sensie spełnienia warunków określonych np. w ustawie z 17 grudnia 1998 r. o emeryturach i rentach z Funduszu Ubezpieczeń Społecznych ${ }^{6}$ ), ale również rozpoczęcie pobierania świadczenia emerytalnego,

4 A. Rycak w komentarzu do art. 38 ust. 1 ustawy o pracownikach samorządowych stwierdza: Ponieważ nie jest z góry pewne, czy wniosek ubezpieczonego o emeryturę lub rentę $z$ tytułu niezdolności do pracy złożony do organu rentowego zakończy się faktycznym uzyskaniem pozytywnej decyzji administracyjnej, pracodawca ma prawo wstrzymać się z wypłata odprawy do dnia uzyskania od ubezpieczonego kopii prawomocnej decyzji organu rentowego (ZUS, KRUS), A. Rycak, M. Rycak, J. Stelina, J. Stępień, Ustawa o pracownikach samorządowych. Komentarz, Warszawa 2016.

5 Zgodnie z uchwałą nr 26 Prezydium Sejmu z 25 września 2001 r. w sprawie szczegółowych zasad i trybu wypłacania uposażenia poselskiego oraz odprawy parlamentarnej poseł ubiegający się o wypłatę lub przyznanie uposażenia składa wniosek, w którym w sposób szczegółowy informuje o aktywności zawodowo-gospodarczej oraz prawie do świadczeń emerytalno-rentowych, a jednocześnie zobowiązuje się do powiadomienia o wszelkich zmianach w tym zakresie.

$6 \quad$ Zgodnie z art. 100 tej ustawy: 1. Prawo do świadczeń określonych $w$ ustawie powstaje $z$ dniem spetnienia wszystkich warunków wymaganych do nabycia tego prawa, $z$ zastrzeżeniem ust. 2.

2. Jeżeli ubezpieczony pobiera zasiłek chorobowy, świadczenie rehabilitacyjne lub wynagrodzenie za czas niezdolności do pracy wypłacane na podstawie przepisów Kodeksu pracy, prawo do emerytury, renty z tytułu niezdolności do pracy lub renty szkoleniowej powstaje z dniem zaprzestania pobierania tego zasiłku, świadczenia lub wynagrodzenia. 
które wiąże się z rozwiązaniem stosunku pracy. W literaturze wskazuje się, że w rozumieniu art. $92^{1}$ k.p. ${ }^{7}$ : Spetnienie przez pracownika warunków uprawniajacych do emerytury lub renty, czyli po prostu nabycie prawa do tych świadczeń, nie wystarcza do przejścia na emeryturę lub rentę. Przejście na emeryturę lub rente musi poprzedzać przyznanie przez organ rentowy jednego z tych świadczeń. Jednak także przyznanie świadczenia nie stanowi samo przez się o przejściu na emeryturę lub rentę. Przejście na emeryturę lub rentę nie jest wprawdzie możliwe bez spetnienia warunków uprawniających do tych świadczeń, ale ich spełnienie jest tylko jedna, pierwsza w kolejności z przesłanek koniecznych do przejścia na emeryture (rentę). Przejście na emeryturę lub rentę następuje bowiem zawsze i tylko przez rozwiązanie stosunku pracy.

W podobny sposób pojęcie „przejście na emeryturę” jest rozumiane również w orzecznictwie, np. w wyroku z 14 czerwca 2012 r. (sygn. akt I PK 229/11) ${ }^{9}$ oraz w wyroku z 2 października 2013 r. (sygn. akt II PK 14/13) ${ }^{10}$ Sąd Najwyższy stwierdził, że przejściem na emeryturę lub rentę w rozumieniu art. $92^{1} \$ 1$ k.p. i art. 38 ust. 3 ustawy o pracownikach samorządowych (który został sformułowany w sposób podobny jak art. 38 ust. 1 u.w.m.p.s. ${ }^{11}$ ) jest zmiana statusu pracownika lub pracownika emeryta (rencisty) na status wyłącznie emeryta (rencisty). W orzecznictwie przyjmuje się, że „przejście na emeryturę” następuje przez ustanie stosunku pracy ${ }^{12}$.

Uwzględniając powyższe, za każdym razem, kiedy poseł występuje o wypłatę odprawy, należałoby ustalić, czy i kiedy miało miejsce rozwiązanie stosunku pracy oraz czy i kiedy poseł rozpoczął pobieranie świadczenia emerytalnego (rentowego).

3. Przepis ust. 2 nie ma zastosowania do emerytury, o której mowa $w$ dziale II rozdział 1.

7 Art. 921. \$ 1. Pracownikowi spetniajacemu warunki uprawniajace do renty z tytułu niezdolności do pracy lub emerytury, którego stosunek pracy ustał w związku z przejściem na rentę lub emeryturę, przysługuje odprawa pieniężna w wysokości jednomiesięcznego wynagrodzenia.

$\$$ 2. Pracownik, który otrzymał odprawę, nie może ponownie nabyć do niej prawa.

8 B. Wagner [w:] Kodeks pracy. Komentarz, red. L. Florek, 2017, LEX.

9 LEX nr 1232231.

10 LEX nr 1388658. Zob. także wyrok z 1 kwietnia 2015 r., sygn. akt II PK 136/14, LEX nr 1666017.

11 3. W związku z przejściem na emeryturę lub rentę z tytułu niezdolności do pracy przystuguje jednorazowa odprawa w wysokości:

1) po 10 latach pracy - dwumiesięcznego wynagrodzenia;

2) po 15 latach pracy - trzymiesięcznego wynagrodzenia;

3) po 20 latach pracy - sześciomiesięcznego wynagrodzenia.

12 Przejście to następuje z reguły jednocześnie z rozwiązaniem stosunku pracy, ale może też nastąpić później ze względu na datę złożenia wniosku lub korzystanie z zasiłku chorobowego (wyrok SN z 14 czerwca 2012 r., sygn. akt I PK 229/11, oraz wyrok SN z 13 stycznia 2011 r., sygn. akt III PK 18/10, LEX nr 1120416). 
3. Co do czasu „przejścia” przepis art. 38 ust. 1 u.w.m.p.s. wskazuje trzy okresy: „W trakcie sprawowania mandatu”, 12 miesięcy po wygaśnięciu mandatu, dwa lata od zakończenia poselskiego urlopu bezpłatnego. Z wyjaśnień przekazanych przez posłów wynika, że przejście na emeryturę miało miejsce w 2009 r. i 2010 r., a zatem chodzi o przejście na emeryturę „w trakcie sprawowania mandatu”.

W związku z ogólną formułą zawartą w art. 38 ust. 1 u.w.m.p.s. „W trakcie sprawowania mandatu" można mieć wątpliwości, czy określenie to odnosi się do danej kadencji (czy chodzi o przejście na emeryturę w trakcie danej kadencji), czy też można je odnosić do kolejnych kadencji, w przypadku gdy poseł zostaje ponownie wybrany.

Za pierwszą interpretacją przemawia charakter odprawy jako jednorazowego świadczenia związanego ze zmianą statusu zawodowego danej osoby: $\mathrm{z}$ pracownika na status emeryta (rencisty) oraz art. 40 u.w.m.p.s. i przepisy wykonawcze do tego aktu. $Z$ literalnego brzmienia fragmentu art. 38 ust. 1 u.w.m.p.s.: „który przechodzi” (a nie np. przeszedł) wynika, że wypłata odprawy powinna mieć miejsce $\mathrm{w}$ okresie bliskim zdarzeniu, jakim jest przejście na emeryturę. Za zbiegiem czasowym realizacji prawa do odprawy z momentem przejścia na emeryturę przemawia również charakter świadczenia, jakim jest odprawa emerytalna. Jako powszechny należy przyjąć pogląd o socjalnym charakterze tego świadczenia, polegającym na rekompensowaniu pracownikowi utraty zatrudnienia w związku z zaistnieniem sytuacji życiowych objętych ryzykiem rentowym lub emerytalnym ${ }^{13}$. Interpretacja pozwalająca na „odkładanie” wypłaty takiego świadczenia w okresie znacznie odległym od nabycia statusu emeryta (np. po 5 latach od tego momentu) przeczyłaby charakterowi i celowi, dla którego ustanowiono omawianą odprawę.

$\mathrm{Z}$ treści art. 40 u.w.m.p.s. regulującego kwestię zbiegu prawa do odprawy emerytalnej i parlamentarnej wynika, że poseł nie ma prawa do pobrania obu odpraw w ramach jednej kadencji Sejmu ${ }^{14}$. Również w przepisach wykonawczych do ustawy o wykonywaniu mandatu posła i senatora jako regułę przyjęto uzależnienie wypłaty odprawy parlamentarnej od tego, czy w danej kadencji poseł otrzymał odprawę na podstawie art. 38 u.w.m.p.s. Na przykład w $\$ 11$ ust. 1 zarządzenia nr 4 Marszałka Sejmu z 19 maja 2011 r. w sprawie niektórych działań dotyczących posłów i ich biur poselskich, związanych z zakończeniem VI i roz-

13 W ten sposób np. M. Piankowski, Ochrona pracowniczych świadczeń majątkowych, Bydgoszcz 2001, s. 70, oraz Sąd Najwyższy np. w uzasadnieniu uchwały z 31 maja 1989 r., sygn. akt III PZP 52/88, OSNC 1989, nr 12, poz. 190.

14 W ten sposób J. Stelina, który podziela stanowisko autorki niniejszej opinii prezentowane m.in. w Zbieg uprawnień do odprawy emerytalno-rentowej i odprawy parlamentarnej [w:] Status posła, cz. II, Wybór ekspertyz prawnych do rozdziału 5 ustawy $z$ dnia 9 maja 1996 r. o wykonywaniu mandatu posła i senatora, red. I. Galińska-Rączy, Warszawa 2007, s. 418 i n. Szerzej na ten temat w komentarzu do art. 40 u.w.m.p.s. [w:] K. Grajewski, J. Stelina, P. Uziębło, Komentarz, op. cit., s. 461. 
poczęciem VII kadencji Sejmu ${ }^{15}$ uzależniono wypłatę odprawy parlamentarnej przysługującej na koniec VI kadencji m.in. od niewypłacenia odprawy emerytalnej (rentowej) w trakcie tej kadencji Sejmu.

Wśród przesłanek warunkujących prawo do odprawy emerytalno-rentowej przysługującej pracownikom, w orzecznictwie sądowym wskazuje się na związek czasowy między ustaniem stosunku pracy a przejściem na emeryturę (rentę) - tak: np. w wyroku Sądu Najwyższego z 20 września 2005 r. (sygn. akt II PK 20/05). W związku z tym, nie można przyjąć za prawidłową interpretacji według której, jeżeli poseł przechodzi na emeryturę np. w IV kadencji Sejmu i jest nadal posłem V i VI kadencji Sejmu, to uprawnienie do odprawy zachowuje przez cały okres sprawowania mandatu i może o nią wystąpić dopiero w VI kadencji. Ponadto z literalnego brzmienia fragmentu: „który przechodzi” (a nie np. przeszedł) wynika, że wypłata odprawy powinna mieć miejsce w okresie bliskim zdarzeniu, jakim jest przejście na emeryturę.

4. Odnosząc powyższe uwagi do podanego stanu faktycznego, należy przyjąć, że obaj posłowie nabyli prawo do odprawy emerytalnej w VI kadencji Sejmu (lata 2007-2011). Fakt, że nie wystąpili wówczas o wypłatę odprawy emerytalnej, skutkuje tym, że w obecnej VIII kadencji Sejmu mogliby oni ubiegać się o wypłatę tego świadczenia, pod warunkiem że roszczenie $\mathrm{z}$ tego tytułu nie uległo przedawnieniu. Ocena, czy nastąpiło przedawnienie, zależy od prawnej kwalifikacji odprawy jako świadczenia, do którego może mieć zastosowanie art. $291 \$ 1$ k.p. ${ }^{16}$ (przewidujący 3-letni termin przedawnienia) albo art. 118 k.c. ${ }^{17}$ (ustalający 10-letni termin przedawnienia).

5. Kwalifikacja omawianej odprawy emerytalnej w zakresie przedawnienia jest trudna, ponieważ przepisy odnoszące się do tego świadczenia nie są jednoznaczne, a w literaturze podkreśla się, że charakter tej odprawy jest sporny ${ }^{18}$.

15 Odprawe parlamentarna wypłaca się posłowi VI kadencji Sejmu, który nie został posłem lub senatorem nowej kadencji oraz któremu w trakcie VI kadencji Sejmu nie została wypłacona odprawa $w$ związku $z$ przejściem na emeryturę lub rentę, po złożeniu rozliczeń środków finansowych wypłaconych $w$ formie miesięcznych ryczałtów przeznaczonych na prowadzenie biura poselskiego w okresie trwania VI kadencji Sejmu oraz po rozliczeniu wszystkich innych zobowiązań wobec Kancelarii Sejmu ujętych w karcie rozliczeń, o której mowa $w \$ 10$. Analogiczny przepis byt zawarty we wcześniejszych i późniejszych zarządzeniach Marszałka wydawanych $w$ związu z zakończeniem kadencji.

16 Art. 291. \$1. Roszczenia ze stosunku pracy ulegaja przedawnieniu z uplywem 3 lat od dnia, w którym roszczenie stało się wymagalne.

17 Art. 118. Jeżeli przepis szczególny nie stanowi inaczej, termin przedawnienia wynosi lat dziesięć, a dla roszczeń o świadczenia okresowe oraz roszczeń związanych z prowadzeniem działalności gospodarczej - trzy lata.

18 Tak stwierdza J. Stelina w komentarzu do art. 38 u.w.m.p.s. [w:] K. Grajewski, J. Stelina, P. Uziębło, Komentarz, op. cit., s. 455. 
Wyrażono np. stanowisko, że świadczenie to należy w zakresie przywilejów egzekucyjnych kwalifikować tak, jak uposażenie poselskie na podstawie art. 27 u.w.m.p.s. ${ }^{19}$, czyli jako wynagrodzenie ze stosunku pracy chronione przed potrąceniami na podstawie art. 87 k.p. ${ }^{20}$. Jako uzasadnienie dla tego stanowiska przywołano ukształtowaną linię orzeczniczą, że odprawa emerytalno-rentowa przysługująca na podstawie przepisów prawa pracy jest wynagrodzeniem za pracę w rozumieniu przepisów o ochronie wynagrodzenia ${ }^{21}$. Jednocześnie stwierdzono, że: istnieje podstawa, by odprawę emerytalna $i$ odprawę rentowa, przysługujace

19 Art. 27. Uposażenie oraz dodatki, o których mowa w art. 26, sa traktowane jako wynagrodzenie ze stosunku pracy.

20 Art. 87. \$ 1. Z wynagrodzenia za prace - po odliczeniu składek na ubezpieczenia społeczne oraz zaliczki na podatek dochodowy od osób fizycznych - podlegaja potraceniu tylko następujące należności:

1) sumy egzekwowane na mocy tytułów wykonawczych na zaspokojenie świadczeń alimentacyjnych;

2) sumy egzekwowane na mocy tytułów wykonawczych na pokrycie należności innych niż świadczenia alimentacyjne;

3) zaliczki pieniężne udzielone pracownikowi;

4) kary pieniężne przewidziane $w$ art. 108.

$\$ 2$. Potrąceń dokonuje się $w$ kolejności podanej $w \$ 1$.

\$3. Potracenia moga być dokonywane w następujących granicach:

1) w razie egzekucji świadczeń alimentacyjnych - do wysokości trzech piątych wynagrodzenia;

2) w razie egzekucji innych należności lub potrącania zaliczek pieniężnych - do wysokości połowy wynagrodzenia.

$\$ 4$. Potracenia, o których mowa w\$ 1 pkt 2 i 3, nie moga w sumie przekraczać połowy wynagrodzenia, a łącznie z potraceniami, o których mowa $w \$ 1$ pkt 1 - trzech piątych wynagrodzenia. Niezależnie od tych potrąceń kary pieniężne potrąca się w granicach określonych $w$ art. 108.

\$5. Nagroda z zakładowego funduszu nagród, dodatkowe wynagrodzenie roczne oraz należności przysługujące pracownikom z tytułu udziału w zysku lub w nadwyżce bilansowej podlegaja egzekucji na zaspokojenie świadczeń alimentacyjnych do pełnej wysokości.

S6. (uchylony).

\$ 7. Z wynagrodzenia za pracę odlicza się, w pełnej wysokości, kwoty wypłacone w poprzednim terminie płatności za okres nieobecności w pracy, za który pracownik nie zachowuje prawa do wynagrodzenia.

$\$ 8$. Potraceń należności $z$ wynagrodzenia pracownika $w$ miesiącu, w którym sa wypłacane składniki wynagrodzenia za okresy dłuższe niż 1 miesiąc, dokonuje się od łącznej kwoty wynagrodzenia uwzględniajacej te składniki wynagrodzenia.

21 J. Stelina w komentarzu do art. 38, op. cit., s. 455, 456, powołuje wyrok SN z 17 lutego 2004 r., sygn. akt I PK 217/03, OSNP 2004, nr 24, poz. 419, w którym stwierdzono: Odprawa emerytalna (art. $92^{1}$ k.p.) oraz nagroda jubileuszowa (art. $77^{3} \$ 3$ pkt 3 k.p.) podlegają ochronie przed potraceniami (art. 87 k.p.) jak wynagrodzenie za pracę. 
na podstawie art. 38 ust. 1 komentowanej ustawy, traktować tak jak uposażenie $z$ wszelkim płynacymi stąd konsekwencjami w zakresie przywilejów egzekucyjnych. Poglad ten znajduje wsparcie $w$ tym, ze pobranie omawianej odprawy wyłacza prawo do analogicznej odprawy przysługujacej $z$ mocy przepisów prawa pracy ${ }^{22}$.

Przyjęcie stanowiska, że omawianą odprawę należy uwzględniać w zakresie przywilejów egzekucyjnych wynikających z prawa pracy (czyli że świadczenie to powinno podlegać ochronie, jak odprawa emerytalno-rentowa przysługująca pracownikom) skutkuje tym, że kwalifikację tę należy również w sposób konsekwentny odnosić do przepisów związanych z przedawnieniem roszczeń. Oznaczałoby to, że w omawianym stanie faktycznym ma zastosowanie art. $291 \$ 1$ k.p., czyli że nastąpiło przedawnienie roszczenia (odpowiednio w roku 2012 i 2013).

Inny pogląd został wyrażony w odniesieniu do odprawy parlamentarnej ${ }^{23}$, która tak jak odprawa emerytalna nie została uwzględniona w art. 27 u.w.m.p.s., stanowiącym, że: [u]posażenie oraz dodatki, o których mowa w art. 26, sa traktowane jako wynagrodzenie ze stosunku pracy. Z. Monkiewicz w opinii pt. Zajęcie odprawy parlamentarnej przez komornika ${ }^{24}$ uznaje, że w świetle powołanego przepisu tylko uposażenie i dodatki do niego są chronione na podstawie art. 87 k.p. Ze stanowiska tej autorki wynika, że odprawa parlamentarna jako świadczenie niemające charakteru uposażenia nie korzysta z ograniczeń egzekucji, jakim podlega wynagrodzenie za pracę. Odnosząc się do wyroku Sądu Najwyższego z 17 lutego 2004 r. (sygn. akt I PK 217/03), w którym uznano, że odprawa emerytalna podlega ochronie przed potrąceniami (art. 87 k.p.) tak, jak wynagrodzenie za pracę, Z. Monkiewicz stwierdza: Sąd Najwyższy wskazał również, iż także $w$ doktrynie prawa pracy przyjmuje się szerokie rozumienie pojęcia wynagrodzenie za prace dla celów ochrony przed potraceniami ze strony pracodawcy (por. J. Iwulski, W. Sanetra: „Kodeks pracy. Komentarz”, Warszawa 2003 tezy do art. 87; odmiennie jednak S. Płażek: „Problem dopuszczalności potrąceń z wierzytelnościami pracownika innymi niż wynagrodzenie", PiZS 1999 nr 12, s. 36). Być może oznaczałoby to możliwość dopuszczenia zastosowania analogicznej ochrony w stosunku do odprawy parlamentarnej, jednakże do możliwości takiej należy podejść z duża ostrożnością. Po pierwsze bowiem przepisy kodeksu pracy odnoszace się do wynagrodzenia za prace maja zastosowanie do posłów jedynie z mocy wyraźnego odesłania, które ograniczone jest do uposażenia i dodatków do niego (poseł nie pozostaje w stosunku pracy), a po drugie świadczenie to przysługuje wszystkim posłom, którzy nie zostali wybrani na następną kadencję, bez względu na to, czy w czasie

22 Ibidem, s. 456.

23 Przysługującej na podstawie art. 39 ust. 1 u.w.m.p.s., który stanowi: Posłowi i senatorowi $w$ zwiazku z zakończeniem kadencji przysługuje odprawa parlamentarna w wysokości trzech uposażeń. Odprawa nie przystuguje, jeżeli poseł lub senator został wybrany na następna kadencje.

24 Publikowanej w: Status posła, op. cit., s. 426-428. 
kadencji pozostawali oni $w$ stosunku pracy $w$ zakładzie pracy ( $i$ w czasie kadencji sejmu korzystali $z$ urlopu bezpłatnego), czy też nie i w zwiazku z tym, czy maja odpowiednie środki na zaspokojenie potrzeb po zakończeniu kadencji ${ }^{25}$.

Autorka powołuje również art. $833 \$ 2$ Kodeksu postępowania cywilnego, który stanowił, że uposażenia poselskie i senatorskie podlegają egzekucji w zakresie określonym w Kodeksie pracy ${ }^{26}$. Przyjęcie powyższej interpretacji będzie oznaczać, że zarówno w odniesieniu do odprawy parlamentarnej, jak i odprawy emerytalnej przysługującej posłom, należałoby stosować art. 118 k.c. ustalający 10-letni termin przedawnienia, nie zaś art. $291 \$ 1$ k.p.

6. Mając na względzie możliwość zastosowania odnośnie do terminu przedawnienia obu wskazanych interpretacji, należy dokonać szerszej analizy prawnego charakteru odprawy emerytalnej przysługującej na podstawie art. 38 u.w.m.p.s.

W literaturze podkreśla się, że dominujące znaczenie dla statusu parlamentarzystów ma pierwiastek publicznoprawny, a pozostawanie w zatrudnieniu o charakterze ustrojowym wyklucza: positkowe stosowanie przepisów regulujących stosunki zatrudnienia pracowniczego, cywilnoprawnego i służbowego, co oznacza, że wszelkie uprawnienia i obowiązki pozostające np. w związku $z$ wykonywaniem mandatu musza być uregulowane w przepisach ustrojowych ${ }^{27}$. Jednocześnie uznaje się, że pozostawanie parlamentarzystów w zatrudnieniu ustrojowym nie jest stosunkiem regulowanym przez prawo pracy, a uposażenie stanowi: rekompensate za specyficzna, niepracownicza prace parlamentarzysty i $w$ istocie petni role wynagrodzenia pracowniczego ${ }^{28}$.

Powyższe twierdzenia wskazują na znaczne trudności z definiowaniem charakteru świadczeń przysługujących parlamentarzystom, ponieważ z jednej strony mówi się o niemożności „posiłkowego stosowania” m.in. przepisów regulujących stosunki pracy (czyli, jak można przypuszczać, również przepisów odnoszących się do przedawnienia roszczeń), a z drugiej przypisuje uposażeniu poselskiemu (senatorskiemu) rolę wynagrodzenia pracowniczego.

Wskazane trudności interpretacyjne wynikają przede wszystkim $\mathrm{z}$ braku szczegółowych regulacji oraz nieprecyzyjności przepisów określających status prawny osób zajmujących kierownicze stanowiska państwowe, czyli osób pozo-

25 Ibidem.

26 W 2005 r. przepis ten obowiązywał w brzmieniu:

Art. 833. \$ 1. Wynagrodzenie ze stosunku pracy podlega egzekucji w zakresie określonym w przepisach Kodeksu pracy. (...)

$\$ 2$. Przepis $₫ 1$ stosuje się odpowiednio do uposażeń posłów i senatorów, należności członków rolniczych spółdzielni produkcyjnych i ich domowników z tytułu pracy w spółdzielni, wynagrodzeń członków spółdzielni pracy oraz wszystkich świadczeń powtarzających się, których celem jest zapewnienie utrzymania.

27 J. Stelina, Komentarz do art. 38, op. cit., s. 334.

28 J. Oniszczuk, w rozdziale Ustrojowo prawne zatrudnienie niepracownicze [w:] System prawa pracy, t. VII, Zatrudnienie niepracownicze, Warszawa 2015, s. 518. 
stających w tzw. stosunkach zatrudnienia konstytucyjnoprawnego ${ }^{29}$. W literaturze podkreśla się, że sytuacja prawna osób piastujących takie stanowiska jest niedookreślona ${ }^{30}$. Jest to zatrudnienie szczególne, zwane „ustrojowoprawnym” lub „konstytucyjnoprawnym” albo „ustrojowym (politycznym)”31, przy czym niektórzy autorzy uznają, że w zatrudnieniu takim pozostają wyłącznie posłowie i senatorowie zawodowi ${ }^{32}$, czyli parlamentarzyści pobierający uposażenie poselskie (senatorskie), a ich status wykazuje zasadnicze podobieństwa do stosunków pracy nawiązywanych na podstawie wyboru ${ }^{33}$.

W literaturze stwierdza się również, że wiele uregulowań ustawy o wykonywaniu mandatu posła i senatora nawiązuje do pojęć i instytucji prawa pracy, a te zapożyczenia mają służyć umożliwieniu i prawidłowej realizacji mandatu parlamentarnego ${ }^{34}$.

Wymienione okoliczności pozwalają na przyjęcie, że ustrojowoprawnemu zatrudnieniu, w jakim pozostają parlamentarzyści, należałoby przypisywać pewne cechy, które są zbliżone najbardziej do zatrudnienia pracowniczego, nie zaś cywilnoprawnego czy administracyjnoprawnego, a w związku z tym do świadczeń przysługujących posłom i senatorom o podobnym charakterze jak wynagrodzenie ze stosunku pracy (a takim jest odprawa emerytalna) należałoby stosować zasady przedawnienia obowiązujące w prawie pracy.

7. Nawet, jeżeli poselskiej odprawie emerytalnej nie przypisywać cech zbliżonych do wynagrodzenia ze stosunku pracy, można kwalifikować ją jako szczególne świadczenie socjalno-bytowe, co oznacza, że możliwe staje się posiłkowe

29 K. Grajewski i K. Stelina wskazują, że w ramach takiego zatrudnienia: osoba fizyczna wykonuje bądź bierze udział w wykonywaniu władzy publicznej w imieniu państwa. W sytuacji prawnej tej osoby dominują czynniki polityczne, zwłaszcza jeśli chodzi o obsadę i utratę danego stanowiska, nie występują natomiast typowe dla innych rodzajów zatrudnienia (głównie pracowniczego i służbowego) więzi o charakterze organizacyjnym (podporządkowanie $i$ dyspozycyjność). Poza parlamentarzystami w zatrudnieniu o charakterze ustrojowym pozostaja m.in. Prezydent RP, prezes Rady Ministrów oraz członkowie rządu, radni samorządowi, członkowie Rady Polityki Pieniężnej itp., K. Grajewski, J. Stelina, P. Uziębło, Komentarz, op. cit., s. 333.

30 Tak A. Dral, Sytuacja prawna osób zatrudnionych na kierowniczych stanowiskach państwowych - uwagi de lege lata $i$ de lege ferenda, http://www.wspia.eu/file/15644/05-Dral.pdf.

31 W ten sposób A. Dral, ibidem, który powołuje A. Kijowskiego, Konstytucyjnoprawne aspekty dopuszczalności pracy nieodpłatnej [w:] Konstytucyjne problemy prawa pracy i zabezpieczenia społecznego, red. H. Szurgacz, Wrocław 2005.

32 A. Dral, Sytuacja prawna, op. cit.

33 W ten sposób W. Sanetra, Uwagi w kwestii zakresu podmiotowego kodeksu pracy [w:] Prawo pracy a wyzwania XXI wieku. Księga jubileuszowa profesora Tadeusza Zielińskiego, Warszawa 2002, s. 310, przywołuję za A. Dralem.

34 Tak: J. Oniszczuk, Ustrojowo prawne zatrudnienie, op. cit., s. 510-512. Autor ten wskazuje art. 25, 27 i 28 u.w.m.p.s. 
odwołanie do orzecznictwa odnoszącego się np. do przedawnienia świadczeń z zakładowego funduszu świadczeń socjalnych. Sąd Najwyższy w wyroku z 4 lipca 2007 r. (sygn. akt II PK 25/07) ) $^{35}$ uznał, że sprawa o roszczenie pracownika z zakładowego funduszu świadczeń socjalnych jest sprawą z zakresu prawa pracy i roszczenie to podlega przedawnieniu, tak jak roszczenie ze stosunku pracy (czyli na podstawie art. 291 \$ 1 k.p.). Także w wyroku z 10 kwietnia 2013 r. (sygn. akt II PK 272/12 ${ }^{36}$ SN stwierdził, że przedawnieniu określonemu w art. $291 \S 1$ k.p. ulegają roszczenia związku zawodowego o zwrot zakładowemu funduszowi świadczeń socjalnych środków wydatkowanych niezgodnie z przepisami ustawy lub o przekazaniu należnych środków na fundusz (art. 8 ust. 3 ustawy z 4 marca 1994 r. o zakładowym funduszu świadczeń socjalnych).

Sąd Najwyższy w tym drugim wyroku przypomniał, że w piśmiennictwie poświęconym przedawnieniu roszczeń w prawie pracy jedynie wyjątkowo dopuszczane jest stosowanie przepisów Kodeksu cywilnego o przedawnieniu. Sąd Najwyższy odwołał się przy tym do poglądu, że przepisy Kodeksu cywilnego mają posiłkowe zastosowanie wtedy, gdy w prawie pracy nie ma ani przepisu, który by normował dane zagadnienie wprost, w ramach instytucji prawnej, w skład której to zagadnienie wchodzi, ani przepisu, który odnosiłby się do podobnego stanu faktycznego.

Odnosząc powyższe do rozważanej kwestii, można stwierdzić, że w związku z tym, że odprawa emerytalno-rentowa przysługująca posłom jest świadczeniem podobnym do odprawy przysługującej pracownikom na podstawie art. $92^{1} \$ 1$ k.p. ${ }^{37}$ albo co najmniej świadczeniem o charakterze socjalnym związanym z pełnieniem mandatu, przedawnienie roszczenia $\mathrm{z}$ tego tytułu per analogiam ulegnie przedawnieniu jak roszczenia ze stosunku pracy albo roszczenia związane ze stosunkiem pracy $^{38}$, czyli w terminie 3-letnim przewidzianym w art. $291 \S 1$ k.p.

\section{Podsumowanie}

- Parlamentarzyści pozostają w niepracowniczym tzw. zatrudnieniu ustrojowym, które, tak jak w przypadku osób zajmujących kierownicze stanowiska państwowe, nie zostało uregulowane w sposób precyzyjny. Jednocześnie nie

35 OSNP 2008, nr 17-18, poz. 251.

36 OSNP 2014, nr 1, poz. 7.

37 K. Grajewski, J. Stelina, Szczególne uprawnienie pracownicze posłów i senatorów, „Przegląd Sejmowy” 2005, nr 1, s. 32, stwierdzają, że prawo do odprawy z art. 38 ust. 1 u.w.m.p.s. jest uprawnieniem zbliżonym (podobnym) do uprawnień pracowniczych.

38 Znamiennym rozstrzygnięciem dla rozważanego problemu jest uchwała 7 sędziów Sądu Najwyższego z 21 listopada 2012 r. (sygn. akt I PZP 1/12, OSNP 2013, nr 11-12, poz. 123), w której uznano, że roszczenie o odszkodowanie od pracodawcy z tytułu utraty prawa do nieodpłatnego nabycia akcji ulega przedawnieniu na podstawie art. $291 \$ 1$ k.p. 
jest jasny charakter odprawy emerytalnej przysługującej na podstawie art. 38 ust. 1 u.w.m.p.s. W literaturze wskazuje się, że jest to świadczenie, które należy traktować jak uposażenie ze wszystkimi tego konsekwencjami np. w zakresie przywilejów egzekucyjnych, czyli że powinno ono podlegać ochronie jak odprawa emerytalno-rentowa przysługująca pracownikom. Stwierdzenie to można odnosić do przepisów związanych z przedawnieniem roszczeń. W związku z tym możliwa jest interpretacja, zgodnie z którą w przypadku pracowniczej odprawy emerytalnej do odprawy przysługującej posłom należy stosować 3-letni termin przedawnienia wynikający z art. $291 \$ 1$ k.p.

- Ponieważ odprawa przysługująca na podstawie art. 38 ust. 1 u.w.m.p.s. nie została uwzględniona w jej art. 27 (czyli m.in. nie podlega ochronie przed egzekucją wynikającą z art. 87 k.p.), możliwa jest również inna interpretacja, uznająca, że świadczenie to (jako świadczenie niebędące wynagrodzeniem ani świadczeniem zrównanym $\mathrm{z}$ wynagrodzeniem) nie podlega przedawnieniu w terminie 3-letnim (na podstawie art. $291 \S 1$ k.p.), ale w terminie 10-letnim określonym w art. 118 k.c.

- Mając na względzie możliwość przypisywania zatrudnieniu ustrojowemu, w jakim pozostają posłowie, pewnych cech, które są zbliżone najbardziej do zatrudnienia pracowniczego, nie zaś cywilnoprawnego, a poselskiej odprawie emerytalnej charakteru podobnego do pracowniczej odprawy emerytalnej (uznawanej przez doktrynę i orzecznictwo za wynagrodzenie ze stosunku pracy), należałoby opowiadać się za stosowaniem 3-letniego terminu przedawnienia obowiązującego w prawie pracy.

\section{Bibliografia}

Dral A., Sytuacja prawna osób zatrudnionych na kierowniczych stanowiskach państwowych - uwagi de lege lata $i$ de lege ferenda, http://www.wspia.eu/file/15644/05-Dral. pdf.

Grajewski K., Stelina J., Szczególne uprawnienie pracownicze posłów i senatorów, „Przegląd Sejmowy” 2005, nr 1.

Iwulski J., Sanetra W., Tezy do art. 87 [w:] J. Iwulski, W. Sanetra, Kodeks pracy. Komentarz, Warszawa 2003.

Kijowski A., Konstytucyjnoprawne aspekty dopuszczalności pracy nieodpłatnej [w:] Konstytucyjne problemy prawa pracy i zabezpieczenia społecznego, red. H. Szurgacz, Wroclaw 2005.

Oniszczuk J., Ustrojowo prawne zatrudnienie niepracownicze [w:] System prawa pracy, t. VII, Zatrudnienie niepracownicze, red. K.W. Baran, Warszawa 2015.

Piankowski M., Ochrona pracowniczych świadczeń majątkowych, Bydgoszcz 2001.

Płażek S., Problem dopuszczalności potrąceń z wierzytelnościami pracownika innymi niż wynagrodzenie, „Praca i Zabezpieczenie Społeczne” 1999, nr 12. 
Rycak A., Komentarz do art. 38 ust. 1 ustawy o pracownikach samorzadowych [w:] Ustawa o pracownikach samorzadowych. Komentarz, A. Rycak, M. Rycak, J. Stelina, J. Stępień, Warszawa 2016.

Sanetra W., Uwagi w kwestii zakresu podmiotowego kodeksu pracy [w:] Prawo pracy a wyzwania XXI wieku. Księga jubileuszowa profesora Tadeusza Zielińskiego, Warszawa 2002.

Stelina J., Komentarz do art. 38 [w:] Komentarz do ustawy o wykonywaniu mandatu posła i senatora, K. Grajewski, J. Stelina, P. Uziębło, Warszawa 2014.

Stelina J., Zbieg uprawnień do odprawy emerytalno-rentowej i odprawy parlamentarnej [w:] Status posła, cz. II, Wybór ekspertyz prawnych do rozdziału 5 ustawy z dnia 9 maja 1996 r. o wykonywaniu mandatu posła i senatora, red. I. Galińska-Rączy, Warszawa 2007.

Wagner B. [w:] Kodeks pracy. Komentarz, L. Florek (red.), 2017, LEX. 


\section{Uprawnienie posła pozbawionego wolności do otrzymywania diety i uposażenia poselskiego ${ }^{1}$}

\footnotetext{
The right of a Deputy who is deprived of liberty to receive a parliamentary per diem allowance and a Deputy's salary (WAKiU-911/18): According to Article 5a of the Act on the Exercise of the Mandate of a Deputy or Senator at the time of deprivation of liberty the Deputy is not entitled to receive parliamentary per diem allowance or a salary. The period of preliminary custody is calculated from the date of detention. An expiry of the period of preliminary custody or repealing of the decision by a court restores to the Deputy a full enjoyment of rights and obligations, and thus enables to receive a parliamentary per diem allowance and a Deputy's salary.
}

Keywords: parliamentary per diem allowance, mandate, Deputy, deprivation of liberty, remuneration

Słowa kluczowe: dieta, mandat, poseł, pozbawienie wolności, wynagrodzenie

Ekspert ds. legislacji BAS; wojciech.sypniewski@sejm.gov.pl.

\section{Przedmiot opinii}

Przedmiotem opinii jest analiza sytuacji prawnej posła pozbawionego wolności. W szczególności chodzi o ocenę skutków zasady określonej w art. 5a ustawy z 9 maja 1996 r. o wykonywaniu mandatu posła i senatora (t.j. Dz.U. 2016, poz. 1510, ze zm.; dalej: ustawa lub u.w.m.p.s.) w odniesieniu do uprawnienia do otrzymywania diety i uposażenia poselskiego. W związku z tym zostanie przedstawiona odpowiedź na następujące pytania:

- „czy treść art. 5a ustawy o wykonywaniu mandatu posła i senatora upoważnia Kancelarię Sejmu do wstrzymania wypłaty diety i uposażenia poselskiego na czas pozbawienia wolności?,

- jeśli tak, to w jakim trybie powinno nastąpić wstrzymanie świadczeń i ewentualne wznowienie wypłaty uposażenia poselskiego i diety poselskiej?,

1 Opinia prawna w sprawie uprawnienia posła pozbawionego wolności do otrzymywania diety i uposażenia poselskiego sporządzona 26 kwietnia 2018 r. na zlecenie dyrektora Biura Obsługi Posłów; BAS-WAKiU 911/18. 
- czy konieczne jest podjęcie w tej sprawie uchwały Prezydium Sejmu, czy też wystarczające jest potwierdzenie faktu pozbawienia wolności np. poprzez zawiadomienie Marszałka Sejmu o tymczasowym aresztowaniu posła za pośrednictwem właściwego sądu?”.

\section{Założenia ustawodawcze (ratio legis) art. 5a ustawy a prawo do uposażenia i diety poselskiej ${ }^{2}$}

1. Zgodnie $\mathrm{z}$ art. 5a u.w.m.p.s.: Poseł lub senator $w$ czasie pozbawienia wolności nie wykonuje praw i obowiązków wynikajacych z niniejszej ustawy. Przepis ten ustanowiony został nowelą ustawy o wykonywaniu mandatu posła i senatora z 6 stycznia 2005 r. (Dz.U. nr 448, poz. 46; dalej: nowela ze stycznia 2005 r.) i służył rozstrzygnięciu wątpliwości, które powstały na tle konkretnego przypadku zatrzymania i tymczasowego aresztowania posła na Sejm $\mathrm{RP}^{3}$. Zaistniała sytuacja zaktualizowała dylematy związane z zakresem praw i obowiązków poselskich, które może wykonywać osoba pozbawiona wolności. Jakkolwiek w piśmiennictwie powszechnie wyrażany był pogląd, że w przypadku kolizji przepisów prawa karnego procesowego oraz wykonawczego i uprawnień wynikających z mandatu poselskiego pierwszeństwo należy przyznać unormowaniom prawnokarnym ${ }^{4}$, to jednak w praktyce delimitacja grupy praw, których wykonywanie w warunkach pozbawienia wolności jest niemożliwe, i tych, które mogłyby być skutecznie realizowane, rodziła istotne trudności. Nowelizacja ustawy ze stycznia 2005 r. zgodnie $\mathrm{z}$ intencją wyrażoną $\mathrm{w}$ projekcie służyć miała "przecięciu” tych wątpliwości. W ocenie wnioskodawcy projektu (grupa posłów): pozbawienie wolności z istoty

2 W opinii wykorzystuję ustalenia przedstawione w opinii prawnej w sprawie statusu posła pełniącego funkcję przewodniczącego komisji sejmowej na tle art. 5a ustawy o wykonywaniu mandatu posła i senatora, 17 kwietnia 2018 r., BAS-WAKiU 844/18, niepubl.

3 Poseł IV kadencji Sejmu A.P. po wyrażeniu przez Sejm zgody - uchwała Sejmu z 19 listopada 2004 r., MP nr 49 poz. 835 - został tymczasowo aresztowany przez organy ściągania.

4 J. Repel, Warunki wykonywania mandatu przez posła (senatora) tymczasowo aresztowanego lub skazanego na karę pozbawienia wolności, s. 29; K. Grajewski, Warunki wykonywania mandatu parlamentarnego przez posła (senatora) tymczasowo aresztowanego lub skazanego na karę pozbawienia wolności, s. 39; W. Odrowąż-Sypniewski, P. Radziewicz, Propozycje zmian do ustawy o wykonywaniu mandatu posła i senatora, dotyczące statusu posła pozbawionego wolności, s. 49; J. Mordwiłko, Możliwość ustawowego uregulowania ograniczenia sprawowania mandatu przedstawiciela pozbawionego wolności, w świetle Konstytucji RP, s. 53 - wszystkie wymienione opinie publikowane [w:] Status posła, cz. I, Wybór ekspertyz prawnych do art. 1-24 ustawy z 9 maja 1996 r. o wykonywaniu mandatu posła i senatora, red. J. Mordwiłko i in., Warszawa 2007. 
swej uniemożliwia wykonywanie mandatu w zakresie obejmującym uczestnictwo parlamentarzysty $w$ pracach Izby i jej organów - co stanowi jedno z podstawowych praw i obowiązków parlamentarzysty wchodzacych $w$ zakres wykonywania mandatu. Status prawny parlamentarzysty pozbawionego wolności, a tym samym potencjalnej możliwości wykonywania mandatu może okazać się zróżnicowany w zależności od przyczyny pozbawienia wolności. Szczegółowe rozróżnienie elementów wykonywania mandatu, które mogłyby być realizowane przez parlamentarzyste pozbawionego wolności, musiałoby być rozstrzygane indywidualnie w każdym przypadku, co zdaniem wnioskodawców uniemożliwia precyzyjna regulacje ustawowa, także ze względu na otwarty katalog form działalności mogacych wchodzić w zakres sprawowania mandatu (art. 6 ust. 2 u.w.m.p.s.). Mając na względzie powyższe, jak również konieczność dbałości o precyzyjne uregulowanie statusu parlamentarzysty pozbawionego wolności i zagwarantowanie przejrzystych zasad funkcjonowania parlamentu, wnioskodawcy uznali za najbardziej racjonalne i odpowiadajace potrzebom rozwiazanie polegajace na wprowadzeniu do systemu prawnego instytucji zawieszenia wykonywania mandatu. Oznaczać to będzie, że poseł pozbawiony wolności nie będzie mógł korzystać z uprawnień wynikających $z$ mandatu (dotyczy to także uprawnień o charakterze finansowo-socjalnym) [podkreślenie W.O.-S.], zachowując jednocześnie status parlamentarzysty. Zawieszenie wykonywania mandatu nie oznacza bowiem jego wygaśnięcia. W szczególności parlamentarzyście nadal przysługiwać będzie immunitet, co oznacza, że np.: postawienie nowych zarzutów możliwe będzie jedynie po spełnieniu warunków określonych $w$ art. 105 Konstytucji i odpowiednich przepisach ustawy o wykonywaniu mandatu posła i senatora (uzasadnienie projektu, druk nr 3576/IV kad.).

Ustanowienie zasady ogólnej ocenione zostało w doktrynie prawa konstytucyjnego bardzo krytycznie. Wskazywano, że przyjęta konstrukcja stoi w sprzeczności z art. 104 ust. 1 Konstytucji, ponieważ pozbawia deputowanego większości praw i obowiązków wiążących się z jego statusem. Samo posiadanie mandatu (w kontekście zawieszenia wynikających z niego praw) staje się pojęciem pustym, pozbawionym treści i w praktyce oznacza faktyczne pozbawianie mandatu przedstawicielskiego. Wskazywano również, że brak jest podstaw normatywnych do dyferencjacji „praw i obowiązków wynikających z ustawy” na te, które zostały skutecznie zawieszone oraz te (immunitet - rozdział 2 u.w.m.p.s.), które w dalszym ciągu mogą być wykonywane przez parlamentarzystę pozbawionego wolności. Krytyka przyjętego przez ustawodawcę rozwiązania nie była powiązana z generalną negacją potrzeby ustawowego określenia statusu pozbawionego wolności deputowanego. Wskazywano jednak, że nowe unormowanie powinno przybrać formę bardziej szczegółowego rozwiązania, które dopuszczałoby wykonywanie tych uprawnień i obowiązków, które nie kolidują ze statusem parlamentarzysty ${ }^{5}$.

5 K. Grajewski, Komentarz do art. 5a [w:] K. Grajewski, J. Stelina, P. Uziębło, Komentarz do ustawy o wykonywaniu mandatu posła i senatora, Warszawa 2014, s. 55-63. 
2. Niezależnie od oceny trafności krytyki wyrażanej przez przedstawicieli doktryny, omawiany przepis obowiązuje i cieszy się domniemaniem zgodności z Konstytucją RP. W konsekwencji organy stosujące prawo zobowiązane są do respektowania wyrażonej w nim zasady, co w szczególności zakłada obowiązek nadawania jej sensu, który w największym stopniu dawałby się pogodzić z ustawą zasadniczą. W dotychczasowej działalności analitycznej BAS (BSiE) wyrażany był pogląd, że: posłowi pozbawionemu wolności nie przysługuje prawo do uprawnień wynikajacych z rozdziału 5 ustawy poselsko-senatorskiej' ${ }^{6}$ Uzasadnienie tej tezy odwoływało się zarówno do argumentów natury historycznej, jak i do wykładni systemowej. Przywołana autorka trafnie wskazywała, że treść art. 5a pozornie mogłaby sugerować, że wynikające $\mathrm{z}$ tego przepisu ograniczenia dotyczą wyłącznie „praw i obowiązków wynikających z (...) ustawy” nie zaś „warunków wykonywania mandatu”, jak, verba legis, określane są przywileje socjalno-bytowe parlamentarzystów (por. tytuł rozdziału 5 ustawy) ${ }^{7}$. Bez wątpienia natura prawna merytorycznych praw związanych z mandatem poselskim (senatorskim) oraz uprawnień finansowo-socjalnych nie jest tożsama. Pierwsze służą realizacji politycznej funkcji przedstawiciela narodu, drugie mają na celu stworzenie gwarancji służących skutecznemu wypełnianiu tego obowiązku. Stanowisko różnicujące - w kontekście art. 5a - kategorię praw mandatowych od uprawnień socjalno-bytowych stałoby jednak sprzeczności z ustaleniami wynikającymi z wykładni historycznej.

Analiza procesu legislacyjnego ustawy jednoznacznie wskazuje, że celem wnioskodawcy noweli ze stycznia 2005 r. było wyłączenie możliwości korzystania z „uprawnień wynikających z ustawy”, która to kategoria - jak poświadcza uzasadnienie projektu - obejmować miała wszelkie uprawnienia o charakterze finansowo-socjalnym. Nie bez znaczenia - w tym kontekście - jest również fakt, że poprawka Senatu zmierzająca do wyłączenia z zakresu „zawieszonych” praw i obowiązków - prawa do uposażenia i diety parlamentarnej ${ }^{8}$ została przez Sejm odrzucona. W konsekwencji należy przyjąć, że intencją ustawodawcy było ustanowienie rozwiązania, które prowadziłoby do wyłączenia możliwości pobierania uposażenia i diety przez parlamentarzystę w okresie pozbawienia wolności9.

Należy zaznaczyć, że w pracach analitycznych BAS (BSiE) towarzyszących noweli ustawy ze stycznia 2005 r. wskazywano możliwości odmiennej regulacji omawianego zagadnienia: W. Odrowąż-Sypniewski, P. Radziewicz, Propozycje zmian, op. cit.; J. Mordwiłko, Roboczy projekt uzasadnienia dla zmiany ustawy o wykonywaniu mandatu posła i senatora, dotyczącej posła (senatora) pozbawionego wolności, z 20 grudnia 2004 r., 2841/04, niepubl.

6 I. Galińska-Rączy, Prawo posła tymczasowo aresztowanego do odprawy parlamentarnej [w:] Status posła, cz. II, Wybór ekspertyz prawnych do rozdziału 5 ustawy z 9 maja 1996 r. o wykonywaniu mandatu posła i senatora, red. I. Galińska-Rączy, Warszawa 2007, s. 422.

7 Ibidem.

8 Zob. uchwała Senatu z 3 lutego 2005 r.; druk senacki nr 3704/IV kad.

9 Ibidem. 
Nawet jeśli uznać, że argument natury historycznej stanowi zbyt wątłą podstawę, by stwierdzić, że treść art. 5a ogranicza prawa socjalno-bytowe posła pozbawionego wolności, to trudno zarazem zignorować znaczenie art. 23 ust. 10a u.w.m.p.s. dla wykładni systemowej ${ }^{10}$. Przepis ten stanowi m.in, że: $w$ przypadku, o którym mowa $w$ art. 5a, prawa $i$ obowiązki posła i senatora wynikajace z funkcjonowania i znoszenia biura przechodza odpowiednio na Marszałka Sejmu lub Marszałka Senatu. Jego celem jest określenie konsekwencji prawnych zasady wyłączającej wykonywanie wynikających z ustawy praw i obowiązków dla kompleksu spraw związanych z prowadzeniem biura poselskiego. Trzeba podkreślić, że znaczenie normatywne art. 23 ust. 10a nie polega na wyłączeniu możliwości prowadzenia przez posła pozbawionego wolności biura poselskiego, lecz jedynie na określeniu następcy prawnego w sferze praw i obowiązków związanych z funkcjonowaniem biura. Źródłem zasady wyłączającej możliwość prowadzenia biura poselskiego jest - jak wynika z art. 23 ust. 10a u.w.m.p.s. - klauzula wyłączająca w sposób generalny możliwość wykonywania praw i obowiązków poselskich w okresie pozbawienia wolności. Treść art. 23 ust. 10a u.w.m.p.s. dotycząca uprawnień o charakterze organizacyjnym - wskazuje, że ustawodawca uznaje, że formuła zawarta w art. 5a ustawy dotyczy wszelkich praw i obowiązków wynikających z ustawy, czyli zarówno praw merytorycznych związanych $\mathrm{z}$ mandatem poselskim (senatorskim), jak i uprawnień organizacyjnych oraz finansowo-socjalnych.

W konsekwencji należy uznać, że wykładnia art. 5a u.w.m.p.s. - na tle jej innych postanowień - potwierdza tezę, że zawarte w tym przepisie wyłączenie możliwości wykonywania praw i obowiązków wynikających z ustawy dotyczy również prawa do pobierania diety i uposażenia.

3. W myśl art. $261 \S 3$ Kodeksu postępowania karnego (dalej: k.p.k.) sąd jest zobowiązany niezwłocznie powiadomić pracodawcę o zastosowaniu tymczasowego aresztowania. Przepis ten należy uznać za źródło ciążącego na sądzie obowiązku powiadomienia Marszałka Sejmu o zastosowaniu wobec posła izolacyjnego środka zapobiegawczego (tymczasowego aresztowania). Okres tymczasowego aresztowania liczy się od dnia zatrzymania (art. 265 k.p.k.). Przekazana Marszałkowi Sejmu przez sąd informacja o tymczasowym aresztowaniu aktualizuje ograniczenia wynikające $\mathrm{z}$ art. 5a u.w.m.p.s. Poseł pozbawiony wolności na skutek tymczasowego aresztowania i zatrzymania nie może wykonywać praw i obowiązków wynikających z ustawy, w tym również nie przysługują mu uprawnienia socjalno-bytowe. W szczególności w okresie pozbawienia wolności brak jest podstaw prawnych do wypłaty uposażenia i diety poselskiej czy też wypłaty odprawy parlamentarnej na podstawie art. 38 ust. 1 u.w.m.p.s. ${ }^{11}$.

\footnotetext{
10 Ibidem.

11 Ibidem.
} 


\section{Podsumowanie}

Podsumowaniem opinii jest pogląd, że zgodnie z art. 5a u.w.m.p.s. posłowi w czasie pozbawienia wolności nie przysługuje prawo do uposażenia i diety poselskiej. Przekazana Marszałkowi Sejmu przez sąd informacja o tymczasowym aresztowaniu aktualizuje ograniczenia wynikające $\mathrm{z}$ art. 5a u.w.m.p.s. Okres tymczasowego aresztowania liczy się od dnia zatrzymania (art. 265 k.p.k.). Upływ okresu tymczasowego aresztowania, uchylenie przez sąd postanowienia o zastosowaniu izolacyjnego środka zapobiegawczego względnie jego zmiana na środek łagodniejszy przywraca posłowi wcześniej pozbawionemu wolności możliwość pełnego korzystania z praw i obowiązków, a tym samym umożliwia pobieranie uposażenia i diety poselskiej. Obowiązujące przepisy nie przewidują żadnej podstawy prawnej dla podejmowania przez Prezydium Sejmu uchwały potwierdzającej fakt pozbawienia wolności.

\section{Bibliografia}

Galińska-Rączy I., Prawo posła tymczasowo aresztowanego do odprawy parlamentarnej [w:] Status posła, cz. II, Wybór ekspertyz prawnych do rozdziału 5 ustawy z 9 maja 1996 r. o wykonywaniu mandatu posła i senatora, red. I. Galińska-Rączy, Warszawa 2007.

Grajewski K., Komentarz do art. 5a [w:] Komentarz do ustawy o wykonywaniu mandatu posła i senatora, red. K. Grajewski, Warszawa 2014.

Grajewski K., Warunki wykonywania mandatu parlamentarnego przez posła (senatora) tymczasowo aresztowanego lub skazanego na karę pozbawienia wolności [w:] Status posła, cz. I, Wybór ekspertyz prawnych do art. 1-24 ustawy z 9 maja 1996 r. o wykonywaniu mandatu posła i senatora, red. J. Mordwiłko i in., Warszawa 2007.

Mordwiłko J., Możliwość ustawowego uregulowania ograniczenia sprawowania mandatu przedstawiciela pozbawionego wolności, w świetle Konstytucji RP [w:] Status posła, cz. I, Wybór ekspertyz prawnych do art. 1-24 ustawy z 9 maja 1996 r. o wykonywaniu mandatu posła i senatora, red. J. Mordwiłko i in., Warszawa 2007.

Odrowąż-Sypniewski W., Radziewicz P., Propozycje zmian do ustawy o wykonywaniu mandatu posła i senatora, dotyczące statusu posła pozbawionego wolności [w:] Status posła, cz. I, Wybór ekspertyz prawnych do art. 1-24 ustawy z 9 maja 1996 r. o wykonywaniu mandatu posła i senatora, red. J. Mordwiłko i in., Warszawa 2007.

Repel J., Warunki wykonywania mandatu przez posła (senatora) tymczasowo aresztowanego lub skazanego na karę pozbawienia wolności [w:] Status posła, cz. I, Wybór ekspertyz prawnych do art. 1-24 ustawy z 9 maja 1996 r. o wykonywaniu mandatu posła i senatora, red. J. Mordwiłko i in., Warszawa 2007. 

2

OPINIE BAS

E

VARIA 



\title{
Udostępnienie przez organ administracji rządowej - w trybie ustawy o dostępie do informacji publicznej - korespondencji w sprawie interwencji poselskiej organowi gminy, którego dotyczy ta interwencja ${ }^{1}$
}

\begin{abstract}
Submitting by a government administration body - under the Act on Access to Public Information - correspondence regarding a Deputy's intervention to a communal body being an addressee of the intervention (WAP-337/18): The purpose of the Act on Access to Public Information is to inform citizens about public matters, and not to obtain information from entities belonging to administration by other administrative authorities. A government administration body is not obliged to provide information to a local selfgovernment administration body, because, as an example, communal authorities cannot be qualified as entities specified in the Act.
\end{abstract}

Keywords: publicadministration, publicinformation,Deputy'sintervention,Deputy, local government

Słowa kluczowe: administracja publiczna, informacja publiczna, interwencje, poseł, samorząd terytorialny

\section{Przedmiot opinii}

Przedmiotem opinii jest odpowiedź na następujące pytanie: „czy organ administracji publicznej (urząd wojewódzki, ministerstwo) w trybie ustawy o dostępie do informacji publicznej jest zobowiązany do udostępnienia treści korespondencji poselskiej wraz z załącznikami, stanowiącymi podstawę do tej interwencji poselskiej, organowi gminy, którego dotyczy ta interwencja?”.

1 Opinia prawna na temat udostępnienia przez organ administracji rządowej $w$ trybie ustawy o dostępie do informacji publicznej korespondencji w sprawie interwencji poselskiej organowi gminy, którego dotyczy ta interwencja sporządzona 2 marca 2018 r. na zlecenie posła Klubu Parlamentarnego Prawo i Sprawiedliwość; BAS-WAP 337/18. 
Opinia uwzględnia stan prawny na dzień jej sporządzenia. W opinii wykorzystano postanowienia następujących aktów prawnych:

- Konstytucja Rzeczypospolitej Polskiej z 2 kwietnia 1997 r., Dz.U. nr 78, poz. 483, ze zm.,

- ustawa z 6 września 2001 r. o dostępie do informacji publicznej, t.j. Dz.U. 2016, poz. 1764, ze zm.; dalej: u.d.i.p.

- ustawa z 6 maja 1996 r. o wykonywaniu mandatu posła i senatora, t.j. Dz.U. 2016, poz. 1510, ze zm.

\section{Uzasadnienie prawne}

1. Kwestia, do której odnosi się sformułowane na wstępie pytanie, wymaga rozstrzygnięcia, czy organy administracji publicznej (w tym organy administracji rządowej, takie jak urząd wojewódzki czy ministerstwo, oraz organy samorządu terytorialnego, czyli np. organy gminy) mogą składać wnioski o udostępnienie informacji publicznych. Bez znaczenia dla tej kwestii pozostaje fakt, że informacje, o których mowa w pytaniu, dotyczą materiałów (w tym korespondencji poselskiej) związanych z interwencją poselską podjętą na podstawie art. 20 ust. 1 ustawy z 6 maja 1996 r. o wykonywaniu mandatu posła i senatora.

Zgodnie $\mathrm{z}$ art. 61 ust. 1 Konstytucji RP obywatel ma prawo uzyskiwania informacji o działalności organów władzy publicznej oraz osób pełniących funkcje publiczne. Prawo to obejmuje również uzyskiwanie informacji o działalności organów samorządu gospodarczego i zawodowego, a także innych osób oraz jednostek organizacyjnych w zakresie, w jakim wykonują one zadania władzy publicznej i gospodarują mieniem komunalnym lub majątkiem Skarbu Państwa. Regulacją będącą rozwinięciem powyższego prawa jest ustawa z 6 września 2001 r. o dostępie do informacji publicznej. Powołany przepis art. 61 ust. 1 Konstytucji RP kształtuje prawo do informacji publicznej jako prawo obywatelskie, natomiast ustawa o dostępie do informacji publicznej (w art. 2 ust. 1) dostęp do informacji publicznej przyznaje „każdemu”.

Kwestia ustalenia kręgu podmiotów uprawnionych do uzyskiwania informacji publicznej na podstawie ustawy o dostępie do informacji publicznej była wielokrotnie przedmiotem rozważań sądów administracyjnych oraz doktryny.

W orzecznictwie wskazuje się, że użyty w art. 2 ust. 1 u.d.i.p. zwrot „każdy” należy rozumieć jako każdy człowiek (osoba fizyczna) lub podmiot prawa prywatnego. Naczelny Sąd Administracyjny w Warszawie w wyroku z 30 stycznia 2014 r., wydanym w sprawie o sygn. I OSK 1982/13, ${ }^{2}$ stwierdził, że: [u]żywając $w$ art. 2 ust. 1 ustawy o dostępie do informacji publicznej pojęcia „każdemu”, ustawodawca precyzuje zastrzeżone $w$ Konstytucji obywatelskie uprawnienie, wskazu-

2 LEX nr 1463438. 
jąc, że każdy może z niego skorzystać na określonych w tej ustawie zasadach. Zwrot „każdy” należy rozumieć jako każdy człowiek lub podmiot prawa prywatnego. Termin „każdy” nie może być inaczej rozumiany, zważywszy na cel i sens ustawy o dostępie do informacji publicznej, przyjętej dla urzeczywistnienia idei transparentności władzy publicznej. Takie rozumienie pojęcia „każdemu” potwierdza stanowisko Trybunału Konstytucyjnego, zaprezentowane w wyroku $z$ dnia 25 maja 2009 r., o sygn. akt SK $54 / 08$.

Jednocześnie sądy uznają, że celem ustawy o dostępie do informacji publicznej jest informowanie obywateli o stanie „spraw publicznych”, a nie, jak to stwierdzono w postanowieniu Wojewódzkiego Sądu Administracyjnego w Warszawie z 18 lutego 2010 r., sygn. akt II SAB/Wa 197/09, ${ }^{3}$ zdobywanie przez organy administracji publicznej informacji od innych podmiotów.

Sądy administracyjne podkreślają również, że przy dokonywaniu wykładni użytego w art. 2 ust. 1 u.d.i.p. pojęcia „każdy” należy wziąć pod uwagę przede wszystkim intencje projektodawców, a z uzasadnienia do poselskiego projektu ustawy o dostępie do informacji publicznej wynika, że celem tym było zapewnienie swego rodzaju „społecznej kontroli” nad organami władzy publicznej, transparentności działania tych organów i zapewnienie aktualnej wiedzy o stanie państwa, samorządów i instytucji publicznych oraz ich majątku4.

Wojewódzki Sąd Administracyjny w Warszawie w wyroku z 13 grudnia 2012 r., sygn. akt II SAB/Wa 386/12, ${ }^{5}$ uznał, że ustawa o dostępie do informacji publicznej służy realizacji konstytucyjnego prawa dostępu do wiedzy na temat funkcjonowania organów władzy publicznej. Racjonalny ustawodawca, używając $w$ art. 2 ust. 1 ustawy pojęcia „każdemu”, precyzuje zastrzeżone $w$ Konstytucji obywatelskie uprawnienie, wskazując, że każdy może z niego skorzystać na określo-

3 WSA wyraził następujące stanowisko: (...) termin ten [każdy] nie może odnosić się do organów administracji publicznej, gdyż ustawa ta ma służyć do „bezpłatnego informowania obywateli w sposób i czasie zapewniający aktualna wiedzę o stanie państwa, samorządów i instytucji publicznych oraz ich majątku" (Uzasadnienie do poselskiego projektu ustawy o dostępie do informacji publicznej - druk sejmowy nr 2094 z 30.VI.2000 r., s. 18). Celem ustawy z 6.IX.2001 r. o dostępie do informacji publicznej jest informowanie obywateli o stanie „spraw publicznych", a nie zdobywanie przez organy administracji publicznej informacji od innych podmiotów (por. wypowiedź T. Górzyńskiej zamieszczona w Biuletynie nr 3614/III kad. Komisja Nadzwyczajna do rozpatrzenia projektów ustaw dotyczacych prawa obywateli do uzyskiwania informacji o działalności organów władzy publicznej oraz osób petniących funkcje publiczne, a także dotyczących jawności procedur decyzyjnych /nr 3/). Tak więc, biorąc pod uwage cel i sens ustawy o dostępie do informacji publicznej, przyjętej przecież dla urzeczywistnienia idei transparentności władzy publicznej, należy wskazać, iż sformułowanie „każdy” oznacza każdego człowieka lub podmiot prawa prywatnego, baza orzeczeń.nsa.gov.pl.

4 Zob. druk sejmowy nr 2094/II kad.

5 LEX nr 1246684. 
nych $w$ tej ustawie zasadach. Przy czym sformułowanie „każdy” należy rozumieć, jako każdy człowiek (osoba fizyczna) lub podmiot prawa prywatnego.

Poglądy powyższe podzielił Wojewódzki Sąd Administracyjny w Gdańsku w wyroku z 5 listopada 2014 r., sygn. akt II SA/Gd 589/14, ${ }^{6}$ przypominając jednocześnie, że przy interpretacji art. 2 u.d.i.p. nie chodzi o zawężenie dostępu do informacji publicznej wyłącznie do osób fizycznych posiadających obywatelstwo polskie, ale że omawiane uprawnienie przysługuje także obywatelom innych państw, bezpaństwowcom oraz osobom prawnym i jednostkom organizacyjnym nieposiadającym osobowości prawnej, takim np. jak stowarzyszenia ${ }^{7}$. WSA uznał, że zasadne jest przyznanie takich uprawnień wyłącznie podmiotom prawa prywatnego. Termin „każdy”, użyty w art. 2 ust. 1 ustawy, nie może odnosić się do organów administracji publicznej, gdyż celem ustawy jest zapewnienie dostępu do informacji o stanie spraw publicznych, a nie umożliwienie organom administracji pozyskiwania informacji od innych podmiotów publicznych lub podmiotów realizujacych zadania publiczne czy też dysponujacych majątkiem publicznym. Zgodzić się bowiem należy, że „przepisy ustawy o dostępie do informacji publicznej nie sa narzędziem prawnym, które ma służyć organom administracji publicznej do wzajemnego przekazywania informacji. Tutaj maja zastosowanie przepisy konstytucyjne oraz administracyjne przepisy ustrojowe. Natomiast ustawa o dostępie do informacji publicznej służy społecznej kontroli władzy publicznej przez społeczeństwo.”(vide P. Szustakiewicz, „Ius Novum” z 2010 r., nr 2, s. 197).

Mając na względzie powyższe argumenty w powołanym wyroku, WSA w Gdańsku uznał, że wójt gminy, będący organem administracji publicznej, nie był uprawniony do wystąpienia o udzielenie informacji publicznej w trybie ustawy o dostępie do informacji publicznej. Sąd ten podkreślił, że: [w]ykonywanie ustawowych zadań organów administracji nie może bowiem odbywać się przy wykorzystaniu ustawy, której celem jest zagwarantowanie obywatelom prawa do informacji publicznej.

2. Podobne stanowisko jest prezentowane w doktrynie. Dla przykładu B. Baran, K. Południak-Gierz w artykule Aspekt podmiotowy udostepniania informacji publicznej na przykładzie regulacji polskich i szwedzkich ${ }^{8}$ uznają, że pojęcie „każdy” z art. 2 ust. 1 u.d.i.p. należy rozumieć jako każdy człowiek lub podmiot prawa prywatnego. Ich zdaniem termin „każdy” nie może być inaczej rozumiany, zważywszy na cel i sens ustawy o dostępie do informacji publicznej, przyjętej dla urzeczywistnienia idei transparentności władzy publicznej.

W ten sam sposób pojęcie „każdy” interpretuje J. Taczkowska-Olszewska, stwierdzając, że celem ustawy o dostępie do informacji publicznej jest informo-

\footnotetext{
LEX nr 1603595.

Zob. wyrok Naczelnego Sądu Administracyjnego z 3 stycznia 2013 r., sygn. akt I OSK 2244/12.

8 „Przegląd Prawa Publicznego” 2017, nr 10, s. 34.
} 
wanie obywateli o stanie „spraw publicznych”, a nie zdobywanie przez organy administracji publicznej informacji od innych podmiotów ${ }^{9}$.

P. Szustakiewicz w komentarzu do art. 2 u.d.i.p. ${ }^{10}$ stwierdza, że organy administracji publicznej nie mogą skutecznie domagać się dostępu do informacji publicznej na podstawie ustawy o dostępie do informacji publicznej, ponieważ pojęcia „każdy” nie można utożsamiać z organem administracji publicznej. Autor ten, przywołując orzecznictwo i poglądy wyrażane w literaturze, uznaje, że ustawa o dostępie do informacji publicznej ustala reguły, według których to podmioty spoza administracji mają kontrolować administrację, a nie administracja ma kontrolować samą siebie. Jednocześnie w komentarzu tym znajdujemy odniesienie do poglądu wyrażonego przez M. Jaśkowską, która w glosie do postanowienia Wojewódzkiego Sądu Administracyjnego w Warszawie z 18 lutego 2010 r., sygn. akt II SAB/Wa 197/09, ${ }^{11}$ uznała, że niekiedy organ administracji występuje jako osoba prawna, a więc może w takiej sytuacji składać wniosek o udostępnienie informacji publicznej ${ }^{12}$. P. Szustakiewicz stwierdza, że takie stanowisko jest możliwe, gdy chodzi o organy społeczne (takie, jak organizacja społeczna lub organ samorządu zawodowego), które wykonując zadania zlecone, działają jako organ administracji, ale dotyczy to sytuacji, gdy taki podmiot wykonuje zadania niezwiązane bezpośrednio z wykonywaniem działań jako organ administracji publicznej. W związku z tym P. Szustakiewicz uznaje, że pogląd wyrażony przez

9 J. Taczkowska-Olszewska, Dostęp do informacji publicznej w polskim systemie prawnym, Warszawa 2014, s. 256.

10 M. Bidziński, M. Chmaj, P. Szustakiewicz, Ustawa o dostępie do informacji publicznej. Komentarz, Warszawa 2015, s. 25 i n.

11 OSP 2011, nr 9, poz. 94, s. 655.

12 Zdaniem M. Jaśkowskiej: podmiotami uprawnionymi do wnioskowania o informacje publiczne moga być także takie, które w innych sytuacjach moga być podmiotami zobowiąanymi. Generalnie rzecz biorac, nic nie stoi zatem na przeszkodzie korzystaniu przez podmioty administracji publicznej, nawet przybierające status organu, z uprawnienia, z jakiego moga one korzystać, będac jednocześnie podmiotem prawa prywatnego - podaję za P.M. Sitniewskim, Dostęp do informacji publicznej, 2014, LEX, pytanie 5. Autor ten stwierdza: M. Jaśkowska przywołuje jako przykład takiego rozumienia zakresu podmiotowego prawa do informacji publicznej postanowienie NSA z 2009 r., w którym skład orzekajacy uchylit postanowienie WSA odrzucajace skarge Prezesa NBP na bezczynność Ministra Finansów w zakresie dostępu do informacji publicznej (postanowienie NSA z dnia 28 października 2009 r., I OSK 508/09, CBOSA). W postanowieniu tym NSA wyraził opinie, iż „fakt, że NBP jako osoba prawna działa na szczególnych warunkach - nie wyklucza możliwości uzyskania przez NBP informacji o działaniu organów władzy publicznej $w$ trybie przepisów ustawy o dostępie do informacji publicznej, jeżeli zakres wniosku o udostępnienie informacji publicznej nie wynika z zakresu współdziałania NBP, jako banku centralnego z organami władzy publicznej”. 
M. Jaśkowską nie jest możliwy do przyjęcia w stosunku do organów administracji rządowej lub organów samorządu terytorialnego.

P.M. Sitniewski, odnosząc się do stanowiska M. Jaśkowskiej, stwierdza: Prawo do informacji publicznej, w moim przekonaniu, przysługuje podmiotom usytuowanym na zewnatrz wobec struktur szeroko rozumianej administracji publicznej. Nie jest to prawo konstytucyjne, z którego miałyby korzystać podmioty publiczne, chcace uzyskiwać informacje o innych podmiotach publicznych. Prawo do informacji publicznej należy traktować jako prawo do bycia poinformowanym, które zostało przewidziane jako instrument szeroko rozumianej kontroli społecznej, sprawowanej wobec organów władzy publicznej i innych podmiotów, którym przysługuje tzw. imperium publiczne $w$ celu wykonywania zadań publicznych. Dlatego te $\dot{z}$, moim zdaniem, przyjęcie bardzo szerokiego zakresu podmiotowego prawa do informacji nie zawsze będzie właściwe. Kontakty pomiędzy instytucjami publicznymi sa regulowane przepisami szczególnymi, określajacymi zarówno elementy proceduralne, jak i materialne oraz podstawy ustrojowe dla tego typu kontaktów. (...) konstytucyjne prawo do informacji publicznej zostało stworzone z myśla o „rządzonych”, nie zaś o „rządzacych”. Jest to prawo, z którego moga korzystać obywatele, ich grupy, stowarzyszenia, fundacje, parafie itd., właśnie dlatego, że chca się dowiedzieć, jak sprawuja władze „rzadzacy”. Nie jest to prawo właściwe dla kontaktów pomiędzy „rzadzacymi”, ale jako instrument kontroli sprawowanej przez „rządzonych” wobec "rzadzacych"13.

Reasumując, należy stwierdzić, że w świetle powyższych stanowisk judykatury i doktryny zasadna jest teza, że ustawa o dostępie do informacji publicznej nie przewiduje uprawnienia organu administracji publicznej do występowania do innego podmiotu zobowiązanego na podstawie art. 4 ust. $1^{14}$ tego aktu ${ }^{15}$.

13 P.M. Sitniewski, Dostęp do informacji publicznej, op. cit., pytanie 5.

14 Art. 4. 1. Obowiazane do udostepniania informacji publicznej sq władze publiczne oraz inne podmioty wykonujace zadania publiczne, w szczególności:

1) organy władzy publicznej;

2) organy samorządów gospodarczych $i$ zawodowych;

3) podmioty reprezentujace zgodnie z odrębnymi przepisami Skarb Państwa;

4) podmioty reprezentujace państwowe osoby prawne albo osoby prawne samorzadu terytorialnego oraz podmioty reprezentujace inne państwowe jednostki organizacyjne albo jednostki organizacyjne samorzadu terytorialnego;

5) podmioty reprezentujące inne osoby lub jednostki organizacyjne, które wykonują zadania publiczne lub dysponuja majątkiem publicznym, oraz osoby prawne, w których Skarb Państwa, jednostki samorządu terytorialnego lub samorzadu gospodarczego albo zawodowego mają pozycję dominująca w rozumieniu przepisów o ochronie konkurencji i konsumentów.

15 Tak: I. Kamińska, J. Matarewicz, M. Rozbicka-Ostrowska, Komentarz do spraw administracyjnych, 2015, LEX. 


\section{Podsumowanie}

- W świetle poglądów wyrażanych w judykaturze oraz doktrynie celem ustawy o dostępie do informacji publicznej jest informowanie obywateli o sprawach publicznych, a nie zdobywanie przez organy administracji publicznej informacji od podmiotów należących do tej administracji.

- Organ administracji rządowej nie ma obowiązku udostępnienia informacji organowi administracji samorządu terytorialnego na podstawie ustawy o dostępie do informacji publicznej, ponieważ np. organy gminy nie mogą być zakwalifikowane jako podmioty określone w art. 2 ust. 1 tej ustawy.

- Odnosząc powyższe rozważania do stanu faktycznego, należałoby uznać, że organ gminy nie jest uprawniony do ubiegania się o udostępnienie informacji publicznej (w tym np. udostępnienie korespondencji poselskiej związanej $\mathrm{z}$ interwencją poselską) $\mathrm{w}$ trybie ustawy o dostępie do informacji publicznej.

\section{Bibliografia}

Baran B., Południak-Gierz K., Aspekt podmiotowy udostępniania informacji publicznej na przykładzie regulacji polskich i szwedzkich, „Przegląd Prawa Publicznego” 2017, nr 10.

Bidziński M., Chmaj M., Szustakiewicz P., Ustawa o dostępie do informacji publicznej. Komentarz, Warszawa 2015.

Kamińska I., Matarewicz J., Rozbicka-Ostrowska M., Komentarz do spraw administracyjnych, 2015, LEX.

Sitniewski P.M., Dostęp do informacji publicznej, 2014, LEX.

Szustakiewicz P., Glosa do postanowienia Naczelnego Sądu Administracyjnego z dnia $28 X$ 2009, Sygn. akt I OSK 508/09, „Ius Novum” 2010, nr 2.

Taczkowska-Olszewska J., Dostęp do informacji publicznej w polskim systemie prawnym, Warszawa 2014. 


\section{Skutki prawne zaciągania przez samorządy terytorialne kredytów konsolidacyjnych w świetle obowiązujących regulacji ustawy o finansach publicznych wraz z oceną możliwości dokonania zmian w tym zakresie ${ }^{1}$}

Legal effects of contracting consolidation credits by local self-governments in the light of current provisions of the Act on Public Finances, along with an assessment of the possibility of future changes in this respect (WASiE 268/18): Within the current state of law, all activities related to contracting a consolidation credit must be included as a revenue and expenditure in the budgetary resolution of a local self-government unit, at the same time affecting the amount of an individual debt ratio. There is no legal basis for directing instructions to the Regional Audit Chambers to change an interpretation of the currently binding legal norms. An amendment to the Act on Public Finances is in the process of drafting, aiming at making possible for local self-government entities to restructure debt through, inter alia, repayment of the existing debt with a new, more favorable consolidation debt.

Keywords: public finance, credit, local self-government, debt

Słowa kluczowe: finanse publiczne, kredyt, samorząd terytorialny, zadłużenie

Doktor hab. nauk prawnych, profesor Uniwersytetu Łódzkiego, ekspert ds. legislacji BAS; hdzwonkowski@poltax.pl.

\section{Przedmiot opinii}

Celem niniejszej opinii jest dokonanie analizy problemów prawno-finansowych, o których mowa w piśmie Prezydenta Miasta Przemyśla z 17 stycznia 2018 r.

Opinia prawna w przedmiocie stanowiska zawartego w piśmie Prezydenta Miasta Przemyśla $z$ dnia 17 stycznia 2018 r. dotycząca skutków prawnych związanych $z$ zaciaganiem przez poszczególne samorządy terytorialne kredytów konsolidacyjnych $w$ świetle obowiązujących regulacji ustawy o finansach publicznych wraz z ocena możliwości dokonania zmian w tym zakresie sporządzona 6 marca 2018 r. na zlecenie p.o. dyrektora generalnego kierującego Gabinetem Marszałka Sejmu; BAS-WASiE 268/18. 
(znak: KPM.033.13.2018), skierowanym m.in. do Marszałka Sejmu RP oraz Ministra Finansów. W piśmie stwierdzono, że miasto Przemyśl, podobnie jak wiele innych ośrodków o porównywalnej wielkości i potencjale gospodarczym, jest żywotnie zainteresowane czynnym udziałem w projektach opracowywanych w ramach „Strategii odpowiedzialnego rozwoju”, w tym przede wszystkim w ogłoszonym w Przemyślu „Pakiecie dla średnich miast”, którego celem jest wyrównanie szans rozwojowych wszystkich obszarów miejskich, w szczególności tych z największymi problemami społeczno-gospodarczymi. Warunkiem uczestnictwa $\mathrm{w}$ tego typu inicjatywach jest jednak konieczność zagwarantowania odpowiedniej kondycji finansowej beneficjenta programu (m.in. zobowiązań i środków własnych). Istotną barierą w tym względzie staje się fakt, że istniejące zobowiązania jednostki samorządu terytorialnego ograniczają szanse na skorzystanie z dostępnych środków zewnętrznych, czyniąc ewentualny udział w programie „Pakietu dla średnich miast” praktycznie niemożliwym. Władze miasta Przemyśla dokonały zatem analizy możliwości zaciągnięcia kredytu konsolidacyjnego, który zmieniłby harmonogram spłaty istniejących zobowiązań. Okazało się jednak, że zgodnie ze stanowiskiem Regionalnej Izby Obrachunkowej w Rzeszowie oraz z orzecznictwem sądów administracyjnych, opartych na postanowieniach ustawy o finansach publicznych ${ }^{2}$, zaciągając tego typu kredyt, należy go uwzględniać (jako przychód i rozchód) w uchwale budżetowej. Prowadzi to do sytuacji, w której wyliczając indywidualny wskaźnik zadłużenia jednostki samorządu, po stronie rozchodów wymagane jest umieszczenie kwoty spłacanej kredytem konsolidacyjnym, co oznacza przekroczenie dopuszczalnego wskaźnika zadłużenia (w przypadku Przemyśla wskaźnik ten wzrasta z poziomu 4,68\% do 30,66\%), a tym samym konieczność stwierdzenia nieważności ewentualnej uchwały o zmianie uchwały budżetowej oraz uchwały o zaciągnięciu kredytu konsolidacyjnego.

W związku z powyższymi ustaleniami Prezydent Miasta Przemyśla zwraca się $\mathrm{z}$ wnioskiem o rozważenie:

- wydania wytycznych dla regionalnych izb rozrachunkowych w zakresie możliwości spłaty kredytów konsolidacyjnych, tak aby rozchód z tym związany nie wpływał negatywnie na ocenę przedsięwzięcia, a gdy nie będzie to możliwe w obecnym stanie prawnym,

- przeprowadzenie pilnej zmiany przepisów ustawy o finansach publicznych, aby uzyskanie kredytu konsolidacyjnego było w praktyce możliwe.

2 Ustawa z 27 sierpnia 2009 r. o finansach publicznych, t.j. Dz.U. 2017, poz. 2077, ze zm.; dalej: ustawa lub u.f.p. 


\section{Analiza zagadnienia}

Przystępując do oceny stanowiska wyrażonego w piśmie Prezydenta Miasta Przemyśla, w pierwszej kolejności należy zwrócić uwagę na uwarunkowania prawne związane z podnoszoną kwestią dotyczącą wpływu faktu zaciągnięcia kredytu konsolidacyjnego na sytuację dotyczącą stanu zadłużenia jednostki samorządu terytorialnego (w tym poziomu indywidualnego wskaźnika zadłużenia). Ustalenia w tym względzie determinują bowiem możliwość rozważenia na dalszym etapie opracowania propozycji wynikających z petycji Prezydenta Miasta Przemyśla.

Przede wszystkim należy sięgnąć do treści obowiązujących przepisów ustawy z 27 sierpnia 2009 r. o finansach publicznych. Ustawa ta w art. 5, dotyczącym środków publicznych, dokonuje wyliczenia poszczególnych rodzajów przychodów i rozchodów gromadzonych w budżecie państwa i budżetach jednostek samorządu terytorialnego oraz ujmowanych w planach finansowych jednostek sektora finansów publicznych. Klasyfikacja przyjęta w tym przepisie dzieli środki publiczne na podstawowe kategorie. Są nimi: dochody publiczne, przychody publiczne oraz środki pochodzące $\mathrm{z}$ budżetu UE i inne bezzwrotne środki ze źródeł zagranicznych, a także środki, o których mowa w ustawie o zasadach prowadzenia polityki rozwoju. Każda z tych kategorii środków publicznych została uszczegółowiona w kolejnych ustępach art. 5 u.f.p. I tak według ust. 1 pkt 4 lit. d środkami publicznymi są przychody budżetu państwa i budżetów jednostek samorządu terytorialnego oraz innych jednostek sektora finansów publicznych pochodzące z otrzymanych pożyczek i kredytów. W art. 5 ustawy posłużono się pojęciami „dochody” i „przychody”, podobnie jak w art. 6 użyto terminów „wydatki” i „rozchody”. Należy przy tym zaznaczyć, że przychody i rozchody są odrębnymi elementami funkcjonowania budżetu w stosunku do dochodów i wydatków. Dochody i wydatki mają charakter podstawowy, a przychody i rozchody uzupełniający, o cechach bankowo-kredytowych. W systemie przychodów budżetowych dominujące znaczenie mają przychody o charakterze zwrotnym³ ${ }^{3}$.

Warto również podkreślić, że w ust. 1 art. 6 określono przeznaczenie środków publicznych, wymienionych w art. 5, dzieląc je na wydatki publiczne i rozchody publiczne, w tym na rozchody budżetu państwa i budżetów jednostek samorządu terytorialnego, natomiast w ust. 2 wskazano rodzaje rozchodów publicznych, wymieniając, że rozchodami publicznymi są m.in.: spłaty otrzymanych pożyczek i kredytów (pkt 1), a także udzielone pożyczki i kredyty (pkt 3).

Mając na uwadze powyższe, należy również stwierdzić, że rozróżnienie wydatków od rozchodów opiera się na kryterium ekonomicznym. Wydatki wiązać należy z redystrybucją definitywną (np. zapłata za towary lub usługi, wypłata wynagrodzeń). Rozchody są związane z czasowym transferem środków. Rozchody

3 Zob. L. Lipiec-Warzecha, Komentarz do art. 5 ustawy o finansach publicznych, LEX. 
publiczne wynikają z konieczności realizacji zobowiązań zaciągniętych uprzednio przez jednostkę sektora finansów publicznych (np. spłata pożyczki lub kredytu) albo wykonania obowiązków umownych polegających na udostępnieniu publicznych zasobów finansowych innym podmiotom (np. udzielenie pożyczki). Wydatki publiczne mają zatem charakter ostateczny, czyli bezzwrotny, a rozchody publiczne cechuje zwrotny charakter płatności. Wyodrębnienie rozchodów umożliwia zachowanie przejrzystości budżetu. Spłata zobowiązań nie stanowi wydatku publicznego. Wydatkiem jest natomiast spłata odsetek i obsługa długu. Ujęte w budżecie państwa, budżetach samorządu terytorialnego oraz w planach finansowych jednostek sektora finansów publicznych wydatki oraz rozchody stanowią nieprzekraczalny limit zwrotny ${ }^{4}$.

Rozwinięcie przedstawionych reguł związanych z przychodami i rozchodami następuje $\mathrm{w}$ art. 89 u.f.p. określającym cele, które mogą być sfinansowane środkami pochodzącymi z kredytu lub pożyczki albo ze sprzedaży papierów wartościowych wyemitowanych przez jednostkę samorządu terytorialnego (ust. 1), m.in. na spłatę wcześniej zaciągniętych zobowiązań z tytułu emisji papierów wartościowych oraz zaciągniętych pożyczek i kredytów (pkt 3). W dalszej kolejności należy wymienić kluczowy dla analizowanej sprawy przepis art. 91 u.f.p. Zgodnie z nim suma zaciągniętych kredytów i pożyczek oraz zobowiązań z wyemitowanych papierów wartościowych, o których mowa w art. 89 ust. 1 ustawy (w tym na spłatę wcześniej zaciągniętych zobowiązań z tytułu zaciągniętych pożyczek i kredytów), nie może przekroczyć kwoty określonej w uchwale budżetowej jednostki samorządu terytorialnego (ust. 1). W przypadku ubiegania się przez jednostkę samorządu terytorialnego o kredyt lub pożyczkę na cel, o którym mowa w art. 89 ust. 1 pkt $2-4$, a także w przypadku zamiaru emisji przez jednostkę samorządu terytorialnego papierów wartościowych na cel, o którym mowa w tym samym przepisie, zarząd tej jednostki jest obowiązany uzyskać opinię regionalnej izby obrachunkowej o możliwości spłaty kredytu lub pożyczki albo wykupu papierów wartościowych (ust. 2).

Jak wynika $\mathrm{z}$ dotychczasowych ustaleń, wymieniony przepis art. 91 u.f.p. w ust. 1 dopuszcza zaciąganie zobowiązań z tytułu kredytów, pożyczek lub wyemitowanych papierów wartościowych do wysokości limitu określonego w uchwale budżetowej. Ograniczenie w korzystaniu ze środków zwrotnych, polegające na obligatoryjnym ustaleniu ich limitu kwotowego w uchwale budżetowej, obejmuje m.in. spłatę wcześniej zaciągniętych zobowiązań z tytułu pożyczek i kredytów. Limit zobowiązań jest obligatoryjnym elementem uchwały budżetowej jednostki samorządu. Oznacza to, że jeśli uchwała budżetowa danej jednostki na dany rok budżetowy nie zawiera - mimo ustawowego wymogu - tego limitu, to gmina nie może zaciągać kredytów lub pożyczek ${ }^{5}$. Zatem ujęcie w uchwale budżetowej

4 Zob. L. Lipiec-Warzecha. Komentarz do art. 6 ustawy o finansach publicznych, LEX.

5 Zob. L. Lipiec-Warzecha. Komentarz do art. 91 ustawy o finansach publicznych, LEX. 
stosownych przychodów determinuje możliwość zaciągania kredytu długoterminowego na spłatę wcześniej zaciągniętych zobowiązań.

Legalną definicję budżetu jednostki samorządu terytorialnego zawiera z kolei norma $\mathrm{z}$ art. 211 u.f.p. Zgodnie $\mathrm{z}$ nią: Budżet jednostki samorządu terytorialnego jest rocznym planem dochodów $i$ wydatków oraz przychodów i rozchodów tej jednostki (ust. 1). Budżet jednostki samorzadu terytorialnego jest uchwalany na rok budżetowy (ust. 2). Rokiem budżetowym jest rok kalendarzowy (ust. 3). Podstawa gospodarki finansowej jednostki samorzadu terytorialnego w danym roku budżetowym jest uchwała budżetowa (ust. 4). Z tak sformułowanej definicji wynikają następujące cechy budżetu jednostki samorządu terytorialnego:

- jest on planem dochodów i wydatków,

- ma charakter roczny,

- jest uchwalany w formie uchwały budżetowej na okres roku budżetowego,

- uchwała budżetowa (której najistotniejszym elementem jest budżet) stanowi podstawę gospodarki finansowej jednostki samorządu terytorialnego w roku budżetowym.

Jednocześnie warto wskazać, że z kolei przepis art. 212 ust. 1 pkt 6 u.f.p. stanowi, że uchwała budżetowa określa: limit zobowiązań z tytułu zaciaganych kredytów i pożyczek oraz emitowanych papierów wartościowych, o których mowa $w$ art. 89 ust. 1 i art. 90 ustawy (w tym również kredytów zaciągniętych na spłatę wcześniej zaciągniętych zobowiązań z tytułu zaciągniętych pożyczek i kredytów). Zatem wskazany limit zobowiązań, w tym dotyczących kredytów konsolidacyjnych, określony tym przepisem jest obligatoryjnym elementem uchwały budżetowej.

Podsumowując powyższe, należy jednoznacznie stwierdzić, że kwotowy przychód z tytułu zaciągniętego kredytu konsolidacyjnego oraz limit zobowiązań z tytułu kredytów zaciągniętych na spłatę wcześniej zaciągniętych zobowiązań (tzw. rolowanie kredytu) musi zostać określony w treści uchwały budżetowej. W konsekwencji podjęcie przez organ stanowiący jednostki samorządu terytorialnego uchwały o zaciągnięciu kredytu konsolidacyjnego na spłatę wcześniej zaciągniętych zobowiązań w postaci kredytów, których wysokość nie została określona w uchwale budżetowej, stanowi istotne naruszenie prawa ${ }^{6}$.

Analizując zagadnienie dotyczące oceny skutków prawnych związanych z zaciąganiem kredytów konsolidacyjnych w świetle wymogów ustawy o finansach publicznych, należy również skierować uwagę na postanowienia art. 243 u.f.p. W obecnym stanie prawnym norma ta wyznacza limit zadłużenia liczony indywidualnie dla każdej jednostki samorządu terytorialnego ustalony według algorytmu przewidzianego tym przepisem. Jej celem jest zapobieżenie sytuacji

6 Por. wyroki Wojewódzkiego Sądu Administracyjnego: w Gdańsku z 11 lutego 2015 r., sygn. akt I SA/Gd 1389/14, oraz w Rzeszowie z 12 czerwca 2007 r., sygn. akt I SA/Rz 400/07, http://orzeczenia.nsa.gov.pl. 
niewypłacalności samorządu i utraty długookresowej płynności, a także przeciwdziałanie zjawisku finansowania działalności bieżącej (operacyjnej) środkami obcymi. W art. 243 ust. 1 ustawy przewidziano, że: [o] rgan stanowiacy jednostki samorzadu terytorialnego nie może uchwalić budżetu, którego realizacja spowoduje, że $w$ roku budżetowym oraz $w$ każdym roku następujacym po roku budżetowym relacja łącznej kwoty przypadajacych $w$ danym roku budżetowym:

1) spłat rat kredytów $i$ pożyczek, o których mowa $w$ (cytowanym powyżej) art. 89 ust. 1 pkt 2-4 oraz art. 90, wraz z należnymi $w$ danym roku odsetkami od kredytów i pożyczek, o których mowa wart. 89 ust. 1 i art. 90,

2) wykupów papierów wartościowych emitowanych na cele określone w art. 89 ust. 1 pkt 2-4 oraz art. 90 wraz z należnymi odsetkami i dyskontem od papierów wartościowych emitowanych na cele określone w art. 89 ust. 1 i art. 90,

3) potencjalnych spłat kwot wynikajacych z udzielonych poręczeń oraz gwarancji

do planowanych dochodów ogółem budżetu przekroczy średnią arytmetyczna z obliczonych dla ostatnich trzech lat relacji jej dochodów bieżacych powiększonych o dochody ze sprzedaży majątku oraz pomniejszonych o wydatki bieżace, do dochodów ogółem budżetu, obliczonq według wzoru (...).

Wszystkie wskazane wyżej i obowiązujące obecnie unormowania ustawy o finansach publicznych prowadzą do kategorycznego wniosku, że zaciągnięcie przez jednostkę samorządu terytorialnego kredytu konsolidacyjnego (w tym również takiego, który nie wydłużając terminu zakończenia spłat, zmieniłby ich harmonogram) musi znaleźć odzwierciedlenie w uchwale budżetowej, poprzez jego właściwe ujęcie. Zaciągnięcie kredytu długoterminowego na spłatę wcześniejszych zobowiązań stanowi nowy tytuł dłużny, gdyż kreuje nowy stosunek zobowiązaniowy między jednostką samorządu terytorialnego a kredytodawcą, dlatego musi znajdować oparcie w wielkościach zaplanowanych w uchwale budżetowej, w postaci ujęcia zarówno przychodów, jak i rozchodów z tytułu nowego kredytu. W rezultacie zaciągnięcie kredytu konsolidacyjnego jest przychodem w rozumieniu art. 5 ust. 1 pkt 4 u.f.p., a jego spłata stanowi rozchód, o którym mowa w art. 6 ust. 2 pkt 1 u.f.p. Powoduje to następstwo w takiej postaci, że fakt wzięcia omawianego kredytu musi wpływać w sposób bezpośredni na indywidualny limit zadłużenia (wskaźnik zadłużenia) wynikający z art. 243 ust. 1 u.f.p.

Powyższego stanowiska nie zmienia treść powołanej przez Prezydenta Miasta Przemyśla w piśmie z 17 stycznia 2018 r. uchwały nr 6 Krajowej Rady Regionalnych Izb Obrachunkowych z 10 czerwca 2011 r. w sprawie kredytów konsolidacyjnych, zgodnie z którą: Krajowa Rada Regionalnych Izb Obrachunkowych stoi na stanowisku, że zaciagnięcie kredytu konsolidacyjnego na spłatę zobowiązań zaciagniętych przez jednostkę samorządu jest możliwe przy spełnieniu warunków określonych w ustawie o finansach publicznych.

1. Konsolidacja długu gminnego (j.s.t.) jest możliwa przy zachowaniu progów dopuszczalnego zadtużenia. 
2. Konsolidacja - umowa o kredyt konsolidacyjny - może być oparta o różne konstrukcje prawne, takie jak np. odnowienie (506-507 kc [Kodeksu cywilnego dopisek H.D.]), wstapienie w prawa zaspokojonego wierzyciela ( $518 \$ 1$ pkt $3 \mathrm{kc}$ ), podstawienie w prawa wierzyciela, zwalniające przejęcie dtugu (519 kc), umowa o zwolnienie z długu (392 kc), spełnienie świadczenia za dłużnika (356 kc), a także inne umowy mieszane lub nienazwane.

3. Konsolidacja długu gminnego jest możliwa, jeżeli wymienione wyżej umowy nie znajduja odzwierciedlenia w obrotach na rachunku bankowym gminy - dłuznika (tzw. pozabilansowa operacja na długu), a także wtedy, gdy takie odzwierciedlenie nastapi, lecz nie doprowadzi to do naruszenia progów dopuszczalnego zadtużenia.

Wymieniona uchwała formułuje jedynie stanowisko Krajowej Rady Regionalnych Izb Obrachunkowych, niemające mocy powszechnie obowiązującej, i w swej preambule oraz treści uzależnia możliwość zaciągnięcie kredytu konsolidacyjnego od spełnienia warunków określonych w ustawie o finansach publicznych. W pkt 1 i 3 uchwała sygnalizuje wyraźne obowiązek zachowania progów dopuszczalnego zadłużenia przy konsolidacji długu jednostki samorządu terytorialnego ${ }^{7}$.

W konsekwencji również Krajowa Rada Regionalnych Izb Obrachunkowych dostrzega, że przy wskazaniu skutków zawierania kredytu konsolidacyjnego nie można pomijać bezwzględnie obowiązujących regulacji zawartych w ustawie o finansach publicznych, które wymagają tego, aby uwzględnić takie zobowiązanie w uchwale budżetowej (jako przychód i rozchód). Zaznaczenia wymaga też to, że przepisy ustawy o finansach publicznych nie czynią w tym względzie jakichkolwiek wyjątków dla spłat dokonywanych w ramach konsolidacji zadłużenia. Także w orzecznictwie sądów administracyjnych podkreśla się, że zagadnienie dotyczące uzyskiwania przez jednostki samorządu wszelkich kredytów: jest bowiem uwarunkowane regulacjami ustawy o finansach publicznych, która określając zasady planowania i dysponowania środkami publicznymi, normuje zasady zaciagania zobowiązań przez jednostki samorządu terytorialnego ${ }^{8}$.

Biorąc pod uwagę wszystkie przedstawione wyżej uwarunkowania, należy dojść do wniosku, że w obecnym stanie prawnym wszelkie czynności związane z zaciąganiem kredytu konsolidacyjnego muszą być uwzględnione (jako przychód i rozchód) w uchwale budżetowej, wpływając tym samym na wysokość indywidualnego wskaźnika zadłużenia. Brak stosowania wobec tego typu operacji uchwały budżetowej i nieuwzględnianie kredytu konsolidacyjnego w toku ustalania wskaźnika zadłużenia oznaczałoby, iż omawiane zobowiązanie de facto

7 Cyt. za: wyrok WSA w Gliwicach z 14 października 2015 r., sygn. akt I SA/Gl 949/15, http://orzeczenia.nsa.gov.pl.

8 Zob. wyrok NSA z 17 października 2017 r., sygn. akt II GSK 227/16, http://orzeczenia. nsa.gov.pl. 
nie byłoby objęte ustawą o finansach publicznych, która w swych założeniach reguluje wszelkie operacje finansowe wnikające $\mathrm{z}$ funkcjonowania jednostki samorządu. W konsekwencji taki stan rzeczy stanowiłby swoistą formę obejścia postanowień obowiązującej ustawy.

Powyższe realia prawne wskazują wyraźnie, że nie zasługuje na uwzględnienie proponowana przez Prezydenta Miasta Przemyśla możliwość skierowania „wytycznych” dla regionalnych izb obrachunkowych celem spowodowania, aby rozchód związany ze spłatą kredytów konsolidacyjnych nie wpływał negatywnie na ocenę stanu zadłużenia, bowiem skutkowałoby to swoistym wyłączeniem stosowania postanowień ustawy o finansach publicznych. Co więcej, ustawa z 7 października 1992 r. o regionalnych izbach rozrachunkowych (t.j. Dz.U. 2016, poz. 561, ze zm.) w art. 2 ust. 1 wyraźnie wskazuje, że nadzór nad działalnością regionalnych izb obrachunkowych sprawuje minister właściwy do spraw administracji publicznej wyłącznie na podstawie kryterium zgodności z prawem (legalności). Również same izby kontrolują gospodarkę finansową, w tym realizację zobowiązań podatkowych oraz zamówienia publiczne jednostek samorządu terytorialnego przede wszystkim na podstawie kryterium zgodności z prawem (art. 5 ust. 1 ustawy o regionalnych izbach rozrachunkowych). Skoro zatem w świetle funkcjonujących obecnie regulacji ustawy o finansach publicznych odpowiadające obowiązującemu prawu (legalne) jest stanowisko - znajdujące swe oparcie także w orzecznictwie wojewódzkich sądów administracyjnych oraz Naczelnego Sądu Administracyjnego - zgodnie z którym kredyt konsolidacyjny wpływa na stan przychodów i rozchodów danej jednostki samorządu, to uznać należy, że nie istnieje pole do działań zmierzających do kierowania wytycznych dla regionalnych izb obrachunkowych celem zmiany istniejącego stanu rzeczy. Wytyczne takie (swoją drogą nieprzewidziane w samej ustawie o izbach rozrachunkowych) nie mogłyby bowiem prowadzić do dokonania interpretacji obowiązujących norm wbrew ich jednoznacznej i precyzyjnej treści.

Wszystkie przedstawione wyżej czynniki dowodzą jednoznacznie, że na gruncie obowiązujących regulacji ustawy o finansach publicznych nie istnieje możliwość, aby zaciągnięty kredyt konsolidacyjny nie mógł być nieuwzględniony jako przychód i rozchód w uchwale budżetowej danej jednostki samorządu oraz nie wpływał na indywidualny wskaźnik zadłużenia.

Aktualna staje się zatem w tym miejscu druga kwestia poruszona przez Prezydenta Miasta Przemyśla, dotycząca celowości dokonania zmiany obowiązujących przepisów ustawy o finansach publicznych, zmierzających do tego, aby uzyskanie przez jednostki samorządu terytorialnego kredytu konsolidacyjnego było w praktyce możliwe.

Za nowelizacją obecnych unormowań może przemawiać argument, że zaciągnięcie kredytu konsolidacyjnego nie powinno być przychodem (a jego spłata rozchodem w rozumieniu ustawy o finansach publicznych), ponieważ kwota uzyskanego świadczenia podlega bezpośredniemu przekazaniu przez bank, któ- 
ry go udziela, dotychczasowym kredytodawcom. Istotą tej operacji jest zatem jedynie konwersja długu, a jej pozabilansowy charakter sprawia, że nie powinna ona znaleźć odzwierciedlenia w uchwale budżetowej i wieloletniej prognozie finansowej. Innymi słowy, zaciągnięcie kredytu konsolidacyjnego jest operacją pozabilansową na istniejącym już długu, polegającą na zamianie wcześniej zaciągniętych kredytów na jeden, dogodniej rozłożony w czasie lub niżej oprocentowany. W rzeczywistości jednostka samorządu przychody nim objęte uzyskała już wcześniej, a konsolidacja doprowadza tylko do scalenia długów w jeden, korzystniejszy. Pod względem ekonomicznym nie zwiększają się też rozchody budżetu z tytułu spłaty takiego kredytu, bo nie zwiększy się ogólne zadłużenie jednostki. Wskazuje się również, że konsolidacja zadłużenia ma głównie na celu refinansowanie długu i zastąpienie wysoko oprocentowanych kredytów i pożyczek nowym, zaciągniętym na atrakcyjniejszych warunkach, co może się przełożyć korzystnie na strukturę zadłużenia jednostki samorządu terytorialnego, co z kolei skutkuje zazwyczaj zmniejszeniem rocznych obciążeń budżetu lub zamianą na instrument o niższym oprocentowaniu9. Z drugiej jednak strony pamiętać należy, iż działania restrukturyzacyjne mogą skutkować też negatywnymi konsekwencjami w postaci wzrostu kosztów obsługi zadłużenia jednostek samorządu terytorialnego ${ }^{10}$. Konsolidacja wiąże się często $\mathrm{z}$ wydłużeniem okresu spłat, a to pociąga za sobą spłaty dodatkowych odsetek, które nalicza także bank konsolidujący. W ostateczności może to prowadzić do zwiększenia ostatecznych kosztów spłaty całości zadłużenia.

Mając na względzie m.in. wskazane wyżej realia o charakterze ekonomicznym, w Ministerstwie Rozwoju i Finansów opracowano projekt nowelizacji ustawy o finansach publicznych ${ }^{11}$, znajdujący się obecnie na etapie uzgodnień. Projekt ten wychodzi naprzeciw oczekiwaniom wynikającym $\mathrm{z}$ analizowanego pisma Prezydenta Miasta Przemyśla, bowiem przewiduje możliwość dokonywania przez jednostki samorządu terytorialnego restrukturyzacji długu poprzez m.in. spłatę istniejącego zadłużenia nowym, korzystniejszym długiem konsolidacyjnym. Inicjatywa ustawodawcza Ministra Rozwoju i Finansów ma w swych zamierzeniach pozwolić na racjonalizację gospodarki finansowej i jednocześnie na zmniejszenie długu publicznego i kosztów jego obsługi. Proponowany nowy przepis art. 243 ust. 3 a pkt 2 u.f.p. przewiduje niestosowanie ograniczenia w spłacie zobowiązań w przypadku restrukturyzacji zadłużenia jednostki samorządu terytorialnego w formie wcześniejszej spłaty istniejącego zadłużenia poprzez za-

\footnotetext{
9 Zob. wyrok WSA w Rzeszowie z 8 maja 2014 r., sygn. akt I SA/Rz 221/14.

10 Zob. D. Jurewicz, Wybrane zagadnienia związane z restrukturyzacja zadtużenia jednostek samorządu terytorialnego na przykładzie samorządów województwa kujawsko-pomorskiego, „Prawo Budżetowe Państwa i Samorządu” 2013, nr 1, s. 77 i n.

11 Projekt z 11 kwietnia 2017 r., numer UD 229, https://legislacja.rcl.gov.pl/docs//2/122 97351/12426490/12426491/dokument284119.pdf.
} 
ciągnięcie nowego długu o niższych kosztach obsługi, przy czym ustalenie kosztów obsługi następować będzie w całym okresie spłaty ${ }^{12}$.

Biorąc pod uwage przedstawione okoliczności związane z wdrożonym przez Ministra Rozwoju i Finansów procesem legislacyjnym, przyjąć należy, że istnieje duże prawdopodobieństwo, iż inicjatywa ta doprowadzi do uchwalenia zmian w ustawie o finansach publicznych, które przyczynią się do zaistnienia stanu prawnego obejmującego uwzględnianie kredytów konsolidacyjnych, zgodnego z oczekiwaniami Prezydenta Miasta Przemyśla. Nowelizacja ta będzie miała w konsekwencji również pozytywny wpływ na możliwość skorzystania przez miasto Przemyśl i inne podobne ośrodki miejskie z programu „Pakiet dla średnich miast".

\section{Bibliografia}

Jurewicz D., Wybrane zagadnienia zwiąane z restrukturyzacja zadłużenia jednostek samorządu terytorialnego na przykładzie samorządów województwa kujawsko-pomorskiego; „Prawo Budżetowe Państwa i Samorządu” 2013, nr 1, https://doi.org/10.12775/ pbps.2013.005.

Lipiec-Warzecha L., Komentarz do ustawy o finansach publicznych, LEX.

12 Uzasadnienie projektu, https://legislacja.rcl.gov.pl/docs//2/12297351/12426490/1242 6491/dokument284123.pdf. 
Irena Galińska-Rączy

\title{
Ocena petycji Andrzeja Halickiego w sprawie nowelizacji ustawy o petycjach w zakresie zamieszczania odpowiedzi na petycję na stronie internetowej podmiotu rozpatrującego petycję oraz zmiany terminu przekazania petycji podmiotowi właściwemu do jej rozpatrzenia'
}

\begin{abstract}
Assessment of Andrzej Halicki's petition concerning amendment of the Act on Petitions as regards publishing a reply to a petition on a website of a respective entity and modifying deadline for transferring petition to a competent entity (WAP-936/18): In the author's opinion the proposed amendments are reasonable and admissible as concerns a legislator's discretion. Such amendment would lead to making proceedings with petitions more transparent and may eliminate an inconsistency between an obligation to publish a scan of a petition and the lack of such obligation regarding a reply to the petition. Moreover, the author supports reducing the deadline for transferring a petition to a competent entity, e.g. to 14 days.
\end{abstract}

Keywords: petition, administrative proceedings

Słowa kluczowe: petycja, postępowanie administracyjne

Ekspert ds. legislacji BAS; irena.galinska-raczy@sejm.gov.pl.

\section{Treść i cel petycji}

Petycja nr BKSP-145-343/18 (dalej: petycja) została wniesiona przez Andrzeja Halickiego (wnoszący petycję złożył oświadczenie o wyrażeniu zgody na publikację petycji z podaniem jego imienia i nazwiska). Petycja zawiera wniosek do-

Opinia prawna dotyczaca petycji Andrzeja Halickiego w sprawie nowelizacji ustawy z dnia 11 lipca 2014 r. o petycjach w zakresie zamieszczania odpowiedzi na petycję na stronie internetowej podmiotu rozpatrującego petycję oraz zmiany terminu przekazania petycji podmiotowi właściwemu do jej rozpatrzenia sporządzona 15 maja 2018 r. na zlecenie przewodniczącego Komisji do Spraw Petycji; BAS-WAP-936/18. 
tyczący zmiany ustawy z 11 lipca 2014 r. o petycjach (Dz.U. 2017, poz. 1123, ze zm.; dalej: ustawa) w zakresie:

- zamieszczania na stronie internetowej podmiotu rozpatrującego petycję skanu odpowiedzi na petycję wniesioną w interesie publicznym (zmiana art. 8 lub art. 13),

- skrócenia terminu przekazania petycji przez adresata petycji niewłaściwego do jej rozpatrzenia do podmiotu właściwego z 30 dni do 14 dni (zmiana art. 6 ust. 1).

Wnoszący petycję proponuje konkretne rozwiązania legislacyjne, przedstawiając nową treść art. 8 ust. 3 (lub art. 13 ust. 3) ustawy oraz art. 6 ust. 1 tego aktu. W petycji zaproponowano:

- dodanie do art. 8 (lub art. 13) ust. 3 w brzmieniu: Na stronie internetowej podmiotu rozpatrujacego petycję lub urzędu go obsługujacego niezwłocznie zamieszcza się informację zawierająca odwzorowanie cyfrowe (skan) odpowiedzi na petycje wniesionej $w$ interesie publicznym,

- zmianę ust. $1 \mathrm{w}$ art. 6 ustawy $^{2}$ poprzez zastąpienie określenia „30 dni” określeniem „14 dni”.

\section{Czy petycja mieści się w zakresie zadań i kompetencji adresata petycji (art. 2 ust. 3 ustawy o petycjach)?}

Petycja będąca przedmiotem niniejszej opinii obejmuje żądanie zmiany przepisów prawa o randze ustawy. Zgodnie z art. 95 ust. 1 Konstytucji RP władzę ustawodawczą w Rzeczypospolitej Polskiej sprawują Sejm i Senat. Natomiast stosownie do art. 118 ust. 1 Konstytucji RP inicjatywa ustawodawcza przysługuje m.in. posłom. Artykuł 32 ust. 2 regulaminu Sejmu, w związku z art. 112 Konstytucji $\mathrm{RP}$, precyzuje, że poselskie projekty ustaw mogą być wnoszone przez komisje sejmowe lub grupę co najmniej 15 posłów podpisujących projekt.

Uwzględniając powyższe, należy uznać, że petycja mieści się w zakresie zadań i kompetencji Sejmu.

\section{Wymogi formalne (art. 4 ust. 1 i ust. 2 oraz art. 12 ustawy o petycjach)}

Petycja spełnia wymogi formalne określone w art. 4 ust. 1 i ust. 2 ustawy o petycjach (zawiera prawidłowe oznaczenie podmiotu wnoszącego petycję oraz wskazanie przedmiotu petycji).

$2 \quad$ Art. 6. 1. Adresat petycji, który jest niewłaściwy do jej rozpatrzenia, przesyła ją niezwłocznie, nie później jednak niż w terminie 30 dni od dnia jej złożenia, do podmiotu właściwego do rozpatrzenia petycji, zawiadamiając o tym równocześnie podmiot wnoszacy petycję. 
Przystępując do merytorycznej oceny propozycji zawartych w petycji, należy zauważyć, że w zakresie nowelizacji art. 8 ustawy autor wniósł wcześniej do Sejmu (28 grudnia 2016 r.) petycję o dokonanie takiej zmiany (petycja nr BKSP145-171/16). Petycja ta została rozpatrzona negatywnie przez Komisję do Spraw Petycji Sejmu RP na posiedzeniu w dniu 20 kwietnia 2017 r. Proponowana obecnie przez A. Halickiego nowelizacja art. 8 (lub 13) różni się od poprzedniej tym, że obowiązek zamieszczania skanu odpowiedzi na petycję odnosiłby się tylko do petycji wnoszonych w interesie publicznym. W petycji zawarto również propozycję dotyczącą zmiany art. 6 ustawy o petycjach.

Nie jest to zatem petycja identyczna z petycją poprzednią, a w związku z tym wątpliwe byłoby zastosowanie do niej art. 12 ust. 1 ustawy ${ }^{3}$ (czyli pozostawienie petycji bez rozpatrzenia), zwłaszcza że Komisja do Spraw Petycji nie uwzględniając żądania będącego przedmiotem petycji z 28 grudnia 2016 r., kierowała się m.in. tym, że „ustawa działa stosunkowo krótko”" a jednocześnie rozważała w przyszłości (np. pod koniec 2017 r.) ponowną analizę zagadnienia zgłoszonego w petycji ${ }^{5}$.

\section{Kwestie, które ekspert uznaje za istotne w związku z petycją}

1. Uzasadniając konieczność nowelizacji art. 8 ust. 3 (lub art. 13 ust. 3) ustawy autor powtarza argumentację zawartą w petycji z 28 grudnia 2016 r. Odnosząc się do tej argumentacji oraz proponowanej treści przepisu (art. 8 ust. 3 lub 13 ust. 3 ustawy), należy przypomnieć, że w opinii Biura Analiz Sejmowych ${ }^{6}$ sporządzonej 15 marca 2017 r. przez prof. dr. hab. A. Szmyta rekomendowano pozytywne załatwienie petycji, wyrażając przekonanie, że wnoszący petycję słusznie wskazuje na: „niesymetryczność, pewna nielogiczność rozwiązania, skoro ustawodawca zdecydował o obowiązku zamieszczania skanu "petycji”, a pominą obowiązek zamieszczania skanu „odpowiedzi na petycję". Jednocześnie w opinii tej za słuszny uznano pogląd, że przyjęcie rozwiązania proponowanego w petycji

3 Art. 12. 1. Podmiot właściwy do rozpatrzenia petycji może pozostawić bez rozpatrzenia petycję złożona $w$ sprawie, która była przedmiotem petycji już rozpatrzonej przez ten podmiot, jeżeli w petycji nie powołano się na nowe fakty lub dowody nieznane podmiotowi właściwemu do rozpatrzenia petycji.

2. W przypadku, o którym mowa $w$ ust. 1, podmiot właściwy do rozpatrzenia petycji niezwłocznie informuje podmiot wnoszacy petycje o pozostawieniu petycji bez rozpatrzenia i poprzednim sposobie załatwienia petycji.

4 Wypowiedź poseł U. Augustyn na 74. posiedzeniu Komisji do spraw Petycji w dniu 20 kwietnia 2017 r., http://www.sejm.gov.pl/Sejm8.nsf/biuletyn.xsp?skrnr=PET-74.

Wypowiedzi posłów S.J. Piechoty i U. Augustyn - ibidem.

6 Opinia prawna dotyczaca petycji A.H. $z$ dnia 28 grudnia 2016 r. do Marszałka Sejmu w sprawie podjęcia działań w celu zmiany ustawy o petycjach, BAS-WAUiP 364/17. 
służyłoby transparentności procesu rozpatrywania petycji, zwłaszcza że obowiązujące przepisy pozwalają osobie postronnej na uzyskanie odpowiedzi na petycję w trybie ustawy z 6 września 2001 r. o dostępie do informacji publicznej (t.j. Dz.U. 2016, poz. 1764, ze zm.). W opinii zwrócono również uwagę na kontekst obywatelskiego prawa do informacji (gwarantowanego w art. 61 Konstytucji $\mathrm{RP}$ ), odnosząc to prawo do umożliwienia obywatelom zapoznania się ze stanowiskiem podmiotu, do którego wniesiono petycję (a nie tylko podmiotowi, który wniósł petycję).

2. Podzielając powyższą ocenę, należałoby wskazać na poglądy wyrażane w literaturze przedmiotu na temat konieczności zachowania jawności i przejrzystości procedury rozpatrywania petycji. Przepisy ustawy o petycjach powinny zapewniać jawność zarówno treści samej petycji, jak i transparentność przebiegu postępowania w sprawach dotyczących petycji, w tym sposobu jej załatwienia. W literaturze podkreśla się, że art. 8 budzi z tego punktu widzenia zastrzeżenia i ustawodawca powinien sprecyzować, że podmioty prowadzące strony podmiotowe Biuletynu Informacji Publicznej (czyli podlegające ustawie o dostępie do informacji publicznej): niezwłocznie udostęniaja na BIP kopie petycji w postaci elektronicznej oraz dane dotyczace przebiegu postępowania, a w szczególności dotyczace zasieganych opinii, przewidywanego terminu oraz sposobu załatwienia petycji ${ }^{7}$.

Z tego względu propozycja zawarta w petycji jest słuszna, bowiem doprecyzowuje zakres informacji, jakie powinny podlegać upublicznieniu. W doktrynie wskazuje się, że obowiązek aktualizacji informacji w zakresie określonym w art. 8 ust. 2 ustawy: to minimum oczekiwane przez ustawodawce, lecz nie ma przeszkód, aby zakres informacji publikowanych elektronicznie był szerszy ${ }^{8}$. Problem polega na tym, jak wykazał to autor w petycji z 28 grudnia 2016 r. (pokazując przykłady stron internetowych dwóch ministerstw, w tym Ministerstwa Sprawiedliwości, na których posłużono się ogólnikową formułą „Odpowiedź na petycję została udzielona wnoszącemu w dniu...” oraz „W dniu ... udzielono odpowiedzi podmiotowi wnoszącemu"9), że podmioty rozpatrujące petycje zazwyczaj ograniczają się do tego minimum.

7 D. Sybilski, Zagadnienie jawności i dostęp do akt w postępowaniach uproszczonych w sprawach skarg, wniosków i petycji [w:] Skargi, wnioski i petycje - powszechne środki ochrony prawnej, red. M. Błachucki, G. Sibiga, Wrocław 2017, s. 95.

8 M. Ożóg, Uregulowanie instytucji petycji w ustawie $z$ dnia 11 lipca 2014 r. o petycjach, „Przegląd Sejmowy” 2015, nr 5(130), s. 135.

9 Ten sposób jest nadal stosowany w Ministerstwie Sprawiedliwości (zob. np. Petycja została załatwiona poprzez odniesienie się do postulatów $w$ niej zawartych i przesłanie jej autorowi odpowiedzi wraz z uzasadnieniem droga elektroniczna $w$ dniu 17 listopada 2017 r. oraz $w$ formie pisemnej, https://bip.ms.gov.pl/pl/kontakt/petycje/zlozone-petycje/news,9918,petycja-w-sprawie-skladania-dokumentow-do.html). 
Należy również odnotować, że w przypadku niektórych podmiotów przyjęto stałą praktykę zamieszczania skanów lub elektronicznych wersji odpowiedzi udzielanych autorom petycji ${ }^{10}$, a nawet wprowadzono przepisy wewnętrzne nakazujące zamieszczanie skanu odpowiedzi na petycję ${ }^{11}$.

W związku z tym ostatnim stwierdzeniem, można uznać, że propozycja zmiany ustawy, o którą wnosi A. Halicki, stanowiłaby dla niektórych podmiotów potwierdzenie dla stosowanej przez nie praktyki, a jednocześnie byłaby wypełnieniem wskazywanego w doktrynie ratio legis art. 8 ust. 2 ustawy (również w kontekście art. 61 Konstytucji RP) oraz art. 63 Konstytucji RP.

3. Istotnym elementem propozycji nowelizacji art. 8 lub art. 13 ustawy zawartym w petycji jest ograniczenie obowiązku zamieszczania skanów odpowiedzi na petycję tylko do petycji podejmowanych w interesie publicznym. Zgodnie $\mathrm{z}$ art. 2 ust. 2 ustawy petycja może być złożona w interesie:

- publicznym,

- podmiotu wnoszącego petycję,

- podmiotu trzeciego, za jego zgodą.

W literaturze zwrócono uwagę zarówno na niejednoznaczność pojęć „interes publiczny”, „interes podmiotu wnoszącego petycję” oraz „interes podmiotu trzeciego", jak i na fakt, że interes publiczny może przeplatać się z interesem własnym $^{12}$.

10 Wśród pozytywnych przykładów podmiotów, które zamieszczają skany odpowiedzi na petycje, wskazać należy Ministerstwo Kultury i Dziedzictwa Narodowego, Rzecznika Praw Obywatelskich i Wojewódzki Sąd Administracyjny w Warszawie. Zob. http:// bip.mkidn.gov.pl/media/docs/petycje/2016/20161018_odpowiedz_na_petycje_p-Cislo.pdf; http://bip.mkidn.gov.pl/media/docs/petycje/2018/20180110;odpowiedź_ na_petycje_w_sprawie_bezpieczenstwa_internetowego.pdf; http://www.bip.brpo. gov.pl/pl/petycja/bdg-wpso05322017 (nota bene przedmiotem tej petycji była kwestia związana z publikacją na stronie BIP RPO odpowiedzi na petycje wnoszone do RPO); http://bip.warszawa.wsa.gov.pl/264/850/petycje-jednostkowe.html.

11 Zarządzenie nr 17/2018/DSS Prezesa Narodowego Funduszu Zdrowia w sprawie przyjmowania i rozpatrywania petycji w Narodowym Funduszu Zdrowia z dnia 1 marca 2018 r., Biuletyn Informacyjny NFZ z 2018 r. poz. 17, zał. nr 2.

12 A. Preisner, P. Kuczma, Zakres przedmiotowy prawa petycji i jego ograniczenia [w:] Teoretyczne i praktyczne aspekty realizacji prawa petycji, red. R. Balicki, M. Jabłoński, Wrocław 2015, s. 419-420. Autor przypomina, że kategoria „interesu” była podważana w toku prac legislacyjnych nad art. 63 Konstytucji, ponieważ: $z$ prawnego punktu widzenia nie jest możliwe precyzyjne ustalenie, $w$ czyim interesie wystapił autor (autorzy) - publicznym lub społecznym czy jak najbardziej egoistycznym własnym, grupowym czy indywidualnym. Czy np. petycja okolicznych mieszkańców przeciwko przeprowadzeniu w pobliżu ich mieszkań drogi szybkiego ruchu, hałaśliwej z natury rzeczy, ale potrzebnej danej społeczności jako całości, miastu jako takiemu, jest wywo- 
Uznaje się, że interes publiczny jest pojęciem niedookreślonym, które nie poddaje się jednoznacznej i uniwersalnej definicji, a jego znaczenie (...) powinno być ustalane każdorazowo w świetle okoliczności faktycznych, do których oceny ma ono zostać zastosowane (...). Nie oznacza to jednak, że nie jest możliwe ustalenie $w$ sposób ogólny pewnych zasadniczych elementów jego znaczenia. Można bowiem przyjąć, że pojęcie interesu publicznego odwotuje się zawsze do pewnych uznanych powszechnie $w$ społeczeństwie wartości, istotnych $z$ punktu widzenia jego prawidłowego funkcjonowania jako całości. Z tego też powodu przy ustalaniu jego treści w odniesieniu do konkretnego przypadku użyteczne będzie odwołanie się do celów $i$ wartości chronionych obowiązującym prawem, $w$ tym $w$ szczególności postanowieniami ustawy zasadniczej (...). Adresat petycji powinien więc każdorazowo badać relacje między żąaniami przedstawionymi w petycji a wartościami, których realizacja optymalizuje funkcjonowanie społeczeństwa jako całości. W przypadku stwierdzenia przynajmniej czesściowej ich zgodności należy przyjać, $\dot{z}$ e petycja wniesiona została $w$ interesie publicznym. Warto jednak zaznaczyć, że interes publiczny nie musi się odnosić do całego społeczeństwa, lecz może dotyczyć pewnej, nawet małej, grupy wyodrębnionej z uwagi na określona cechę relewantna (np. mieszkańców danego osiedla, studentów określonej szkoły wyższej, osób zagrożonych dana inicjatywa $)^{13}$.

Interpretując pojęcie „interes publiczny”, uznaje się, że: interes ten nie jest zbieżny z pojęciem interesu państwowego, choć krzyżuje się z tym pojęciem. Interes publiczny to też nie interes ogólnospołeczny (wynikający z ochrony dobra wspólnego), gdyż znaczeniowo jest szerszy: każdy interes ogólnospołeczny jest interesem publicznym, ale nie każdy interes publiczny będzie interesem ogólnospołecznym ${ }^{14}$.

W literaturze wskazuje się również, że użyte np. w art. $221 \$ 3$ Kodeksu postępowania administracyjnego (dalej: k.p.a.) (Skargi $i$ wnioski można składać w interesie publicznym, własnym lub innej osoby za jej zgoda) pojęcie „interes publiczny” jest tożsame z pojęciem „interes społeczny”.

łana interesem publicznym, czy też jej motywację musimy definiować w zupełnie inny sposób?

13 S. Gajewski, A. Jakubowski, Petycje, skargi i wnioski, Dział VIII Kodeksu postępowania administracyjnego. Ustawa o petycjach. Komentarz, Warszawa 2015, Legalis, komentarz do art. 2 ustawy.

14 R. Galicki, Wykorzystanie instytucji petycji, wniosków i skarg przez zwiazki zawodowe - analiza dogmatyczna [w:] Skargi, wnioski i petycje - powszechne środki ochrony prawnej, red. M. Błachucki, G. Sibiga, Wrocław 2017, s. 141-142. Autor ten uznaje, że np. zbiorowy interes pracowników jako pewnej grupy społecznej staje się interesem publicznym.

15 W ten sposób: P.M. Przybysz, Kodeks postępowania administracyjnego. Komentarz, 2018, LEX, oraz J. Borkowski [w:] B. Adamiak, J. Borkowski, Kodeks postępowania administracyjnego, Warszawa 2006, s. 831, który przypomniał, że w art. $221 \$ 3$ k.p.a. zastąpiono dawne określenie „interes społeczny” określeniem „interes publiczny” 
Pewne aspekty definicji interesu publicznego (społecznego) zawarte w literaturze prawniczej przedstawiono w uzasadnieniu wyroku Wojewódzkiego Sądu Administracyjnego w Bydgoszczy z 18 czerwca 2008 r. (sygn. akt II SA/ Bd 111/08 ${ }^{16}$. Sąd ten stwierdził: Kategoria interesu społecznego jest pojęciem dynamicznym, stopniowalnym i zmiennym $w$ czasie. Pojęcie to należy każdorazowo rozpatrywać na tle konkretnej sprawy.

Rozważając wprowadzenie proponowanego w petycji ograniczenia upubliczniania skanu odpowiedzi tylko w odniesieniu do petycji wnoszonych w interesie publicznym, należałoby mieć na uwadze potencjalną trudność z ustaleniem w czyim interesie jest wnoszona dana petycja.

Istotny wydaje się przy tym fakt, że wprowadzając w art. 8 ustawy obowiązek zamieszczania skanu petycji nadano publiczny charakter każdej z petycji, nie różnicując go w zależności od tego, czy petycja jest wnoszona w interesie publicznym czy indywidualnym. Ponadto trzeba mieć na względzie, że upublicznieniu (jak mówi art. 11 ust. 4 ustawy: „ogłoszeniu na stronie internetowej”) podlega „sposób załatwienia petycji wielokrotnej” - niezależnie od tego, w czyim interesie są wnoszone dalsze petycje odnoszące się do tej samej sprawy.

Rozpatrzenie petycji - nawet tej wnoszonej w interesie własnym lub w interesie podmiotu trzeciego - stanowiąc realizację ustawowo określonego zadania, będzie dotyczyć sprawy publicznej, a więc może być kwalifikowane jako informacja publiczna ${ }^{17}$. W literaturze stwierdzono, że przepisy ustawy z 6 września 2001 r. o dostępie do informacji publicznej: staną się podstawa do formułowania

i że w doktrynie uznawano, że są to pojęcia ze sobą zamienne. A. Gomułowicz, A.P. Skoczylas, Zakres znaczeniowy - sposób rozumienia „interesu społecznego” (w kontekście innych pojęć niedookreślonych stosowanych przez sądy administracyjne) [w:]

A. Choduń, A. Gomułowicz, A.P. Skoczylas, Klauzule generalne i zwroty niedookreślone w prawie podatkowym i administracyjnym, 2013, LEX, odwołując się do teorii prawa (wedle której kategoria interesu publicznego ma charakter klauzuli generalnej) oraz orzecznictwa stwierdzają, że dokonując interpretacji pojęcia „interes społeczny”, należy mieć na względzie, że: zastosowanie pojęcia nieostrego wymaga wskazania nie tylko jego uwarunkowań zewnętrznych wynikajacych $z$ chronionych wartości zawartych $w$ calym systemie prawa, ale i jego uwarunkowań wynikających $z$ wartości i zasad leżących u podstaw aktu normatywnego, w którym zastosowano dane pojęcie nieostre. Dopiero wtedy dokonana ocena szczegółowo ustalonych okoliczności sprawy nie nosi cech dowolności i mieści się w ramach dopuszczalnego stosowania pojęcia nieostrego.

16 LEX nr 510786.

17 W ten sposób: D. Sybilski, Zagadnienie jawności i dostęp do akt w postępowaniach uproszczonych w sprawach skarg, wniosków i petycji [w:] Skargi, wnioski i petycje - powszechne środki ochrony prawnej, red. M. Błachucki, G. Sibiga, Wrocław 2017, s. 90. Autor ten powołuje się na poglądy wyrażane w doktrynie, jak również w orzecznictwie (wyrok Wojewódzkiego Sądu Administracyjnego w Lublinie z 18 grudnia 2012 r., sygn. akt II SA/Lu 821/12, LEX nr 1351692) co do identyfikacji treści skarg i „efektów” ich rozpatrzenia przez organy publiczne jako informacji publicznej. 
następczych wystąpień ( $w$ zakresie dostępu do informacji publicznych) stużących weryfikacji zapewnień (obietnic, ale również przedstawionych faktów) poczynionych przez adresata petycji ${ }^{18}$.

Mając na względzie powyższe, korzystniejsze wydaje się rozwiązanie, zgodnie z którym upublicznianiu podlegałyby odpowiedzi na wszystkie petycje (po stosownej anonimizacji danych) - a nie tylko te wnoszone w interesie publicznym. Takie rozwiązanie jest również uzasadnione ekonomiką postępowania (w przypadku publikowania skanów odpowiedzi na petycje - brak konieczności przekazywania zainteresowanym tych odpowiedzi w trybie wnioskowym ${ }^{19}$ ).

4. Właściwszym miejscem dla omawianej zmiany wydaje się art. 13 ustawy, który odnosi się do ostatniej fazy postępowania z petycjami, jaką jest zawiadomienie (w formie pisemnej lub elektronicznej) podmiotu wnoszącego petycję „o sposobie jej załatwienia wraz z uzasadnieniem”. Zawiadomienie to należy per analogiam uznać za czynność materialno-techniczną, która kończy postępowanie, tak jak za taką czynność uznaje się zawiadomienie o sposobie załatwienia skargi ${ }^{20}$.

Artykuł 8 odnosi się w sposób wyraźny do etapów poprzedzających tę fazę ${ }^{21}$, a więc do złożenia petycji (zamieszczenia jej skanu na stronie internetowej pod-

W myśl art. 6 ust. 1 pkt 4 ustawy o dostępie do informacji publicznej: Udostępnieniu podlega informacja publiczna, w szczególności o: (...) 4) danych publicznych, w tym:

a) treść i postać dokumentów urzędowych, w szczególności:

- treść aktów administracyjnych i innych rozstrzygnięć,

- dokumentacja przebiegu i efektów kontroli oraz wystapienia, stanowiska, wnioski i opinie podmiotów ja przeprowadzających,

- treść orzeczeń sądów powszechnych, Sądu Najwyższego, sądów administracyjnych, sadów wojskowych, Trybunału Konstytucyjnego i Trybunału Stanu,

b) stanowiska $w$ sprawach publicznych zajęte przez organy władzy publicznej i przez funkcjonariuszy publicznych $w$ rozumieniu przepisów Kodeksu karnego,

c) treść innych wystąień i ocen dokonywanych przez organy władzy publicznej,

d) informacja o stanie państwa, samorządów i ich jednostek organizacyjnych; (...).

18 M. Jabłoński, Prawo dostępu do informacji publicznej a prawo petycji [w:] Teoretyczne i praktyczne aspekty realizacji prawa petycji, red. R. Balicki, M. Jabłoński, Wrocław 2015, s. 336.

19 Czyli na podstawie art. 10 ust. 1 ustawy o dostępie do informacji publicznej, który stanowi: Informacja publiczna, która nie została udostępniona w Biuletynie Informacji Publicznej lub centralnym repozytorium, jest udostęniana na wniosek.

20 Z. Kmieciak, Zarys teorii postępowania administracyjnego, 2014, LEX, oraz wyrok Wojewódzkiego Sądu Administracyjnego w Gorzowie Wielkopolskim z 29 grudnia 2010 r. (sygn. akt II SA/Go 824/10, LEX nr 753182), w którym stwierdzono: Tryb „ogólnoskargowy” (art. 221-240 k.p.a.) jest samodzielnym, jednoinstancyjnym postępowaniem o charakterze uproszczonym, które kończy się czynnościq materialno-techniczna (zawiadomieniem o sposobie załatwienia skargi).

${ }^{21}$ Art. 8. 1. Na stronie internetowej podmiotu rozpatrujacego petycję lub urzędu go obstugujacego niezwłocznie zamieszcza się informację zawierająca odwzorowanie cyfrowe 
miotu rozpatrującego petycję wraz z informacją o dacie jej złożenia i danych podmiotu, który petycję złożył), przebiegu postępowania (polegającego m.in. na zasięganiu opinii) oraz przewidywań co do terminu i sposobu załatwienia petycji.

5. W petycji proponuje się użycie zwrotu „odwzorowanie cyfrowe (skan) odpowiedzi na petycję". Ani w art. 8, ani w art. 13 ustawy nie posłużono się określeniem "odpowiedź na petycję" (pojęcia takiego nie znajdujemy również w pozostałych przepisach ustawy), natomiast w art. 8, 11, 12, 13 i 14 użyto określenia „sposób załatwienia petycji”. Analizując proponowaną w petycji nowelizację art. 8 lub 13 ustawy, należałoby ewentualnie rozważyć ujednolicenie tych pojęć.

Z drugiej jednak strony w doktrynie wskazano, że w klauzuli odsyłającej do ustawy zawartej w art. 63 zdanie drugie Konstytucji RP („Tryb rozpatrywania petycji, wniosków i skarg określa ustawa”) na adresatów m.in. petycji zostały nałożone dwa szczególne obowiązki: rozpatrzenia i udzielenia odpowiedzi autorowi (autorom) petycji ${ }^{22}$. Interpretując na gruncie ustawy pojęcie „sposób rozpatrzenia petycji” uznaje się, że chodzi o: obowiązek sporządzenia uzasadnionej, pisemnej odpowiedzi ustosunkowującej się do żądań, twierdzeń, ocen przedstawionych $w$ petycji $i^{23}$. Jednocześnie stwierdza się, że w świetle art. 63 zdanie drugie Konstytucji RP do obowiązków rozpatrującego petycję należy m.in. „udzielenie odpowiedzi na petycję ze wskazaniem sposobu jej załatwienia"24.

W omawianej kwestii można się również odwołać do interpretacji art. $239 \$ 1$ k.p.a. ${ }^{25}$ (będącego odpowiednikiem art. 12 ustawy): Przez odpowiedź na skargę, o której mowa w początkowej części art. 239 \$1, należy rozumieć zawiadomienie

(skan) petycji, datę jej złożenia oraz - w przypadku wyrażenia zgody, o której mowa w art. 4 ust. 3 - imię i nazwisko albo nazwę podmiotu wnoszacego petycję lub podmiotu, $w$ interesie którego petycja jest składana.

2. Informacja, o której mowa w ust. 1, jest niezwłocznie aktualizowana o dane dotyczace przebiegu postępowania, w szczególności dotyczące zasięganych opinii, przewidywanego terminu oraz sposobu załatwienia petycji.

22 M. Pisz, Gwarancje realizacji konstytucyjnego prawa do petycji w kontekście ustawy $z$ dnia 11 lipca 2014 r. o petycjach, „Przegląd Legislacyjny” 2016, nr 2, s. 54-55. Autor powołuje W. Sokolewicza oraz P. Winczorka.

23 M. Bernaczyk, Postępowanie w przedmiocie rozpatrzenia petycji [w:] Teoretyczne i praktyczne aspekty realizacji prawa petycji, red. R. Balicki, M. Jabłoński, Wrocław 2015, s. 465.

24 M. Jackowski, Prawo petycji a actio popularis [w:] Teoretyczne i praktyczne aspekty realizacji prawa petycji, red. R. Balicki, M. Jabłoński, Wrocław 2015, s. 361.

25 Art. 239. \$1. W przypadku gdy skarga, w wyniku jej rozpatrzenia, została uznana za bezzasadna i jej bezzasadność wykazano w odpowiedzi na skargę, a skarżacy ponowit skarge bez wskazania nowych okoliczności - organ właściwy do jej rozpatrzenia może podtrzymać swoje poprzednie stanowisko $z$ odpowiednia adnotacja w aktach sprawy bez zawiadamiania skarżącego. 
o sposobie rozpatrzenia skargi przedstawiajace stanowisko $w$ sprawie skargi, spetniajace wymagania określone $w$ art. $238^{26}$.

Mając na uwadze powyższe, wydaje się, że w przypadku proponowanej w petycji zmiany nie jest konieczne ujednolicenie pojęć „odpowiedź na petycję” i „sposób załatwienia petycji”.

6. Postulat zmiany art. 6 ust. 1 ustawy został uzasadniony przez wnoszącego petycję tym, że obecny 30-dniowy termin na przesłanie przez adresata petycji podmiotowi właściwemu wydaje się zbyt długi, ponieważ adresat posiada najlepsza wiedzę o swoich zadaniach $i$ kompetencjach $i$ jest $w$ stanie dokonać stosownej oceny petycji w tym obszarze w przeciagu znacznie krótszego czasu. Autor petycji wskazał przy tym art. 231 k.p.a. ${ }^{27}$, który wyznacza adresatowi skargi termin 7-dniowy na przekazanie jej organowi właściwemu, uznając jednocześnie, że brak jest logicznych argumentów, które uzasadniałyby pozostawienie tak długiego terminu w przypadku petycji.

Popierając ten postulat wnoszącego petycję, można przywołać stanowisko, że zadaniem art. 231 k.p.a. jest spowodowanie szybkiego rozstrzygnięcia kwestii właściwości organu do rozpatrzenia skargi ${ }^{28}$. Taki sam 7-dniowy termin został ustalony w art. 243 k.p.a. w odniesieniu do wniosku ${ }^{29}$.

W literaturze wskazuje się, że zróżnicowanie terminów na przekazanie pisma organowi właściwemu w przypadku skargi, wniosku i petycji jest przejawem braku skorelowania przepisów ustawy o petycjach z Kodeksem postępowania administracyjnego ${ }^{30}$. Jednocześnie stwierdza się: Brak (...) racjonalnych argumentów przemawiajacych za 30-dniowym terminem na przekazanie petycji or-

26 P.M. Przybysz, Kodeks postępowania administracyjnego. Komentarz, 2018, LEX. W związku $\mathrm{z}$ nieokreśleniem w ustawie wymogów co do elementów treściowych zawiadomienia o sposobie załatwienia petycji oraz art. 15 ustawy do postępowania z petycjami, należy stosować odpowiednio m.in. art. $238 \$ 1$ k.p.a. [1. Zawiadomienie o sposobie załatwienia skargi powinno zawierać: oznaczenie organu, od którego pochodzi, wskazanie, $w$ jaki sposób skarga została załatwiona, oraz podpis z podaniem imienia, nazwiska i stanowiska służbowego osoby upoważnionej do załatwienia skargi lub, jeżeli zawiadomienie sporzadzone zostało $w$ formie dokumentu elektronicznego, powinno być opatrzone kwalifikowanym podpisem elektronicznym.(...)].

27 Art. 231. Jeżeli organ, który otrzymał skargę, nie jest właściwy do jej rozpatrzenia, obowiązany jest niezwłocznie, nie później jednak niż w terminie siedmiu dni, przekazać ja właściwemu organowi, zawiadamiając równocześnie o tym skarżacego, albo wskazać mu właściwy organ.

28 P.M. Przybysz, Kodeks postępowania administracyjnego. Komentarz aktualizowany, 2018, LEX, komentarz do art. 231 k.p.a.

29 Jeżeli organ, który otrzymat wniosek, nie jest właściwy do jego rozpatrzenia, obowiązany jest w ciagu siedmiu dni przekazać go właściwemu organowi. O przekazaniu wniosku zawiadamia się równocześnie wnioskodawcę.

30 M. Ożóg, Uregulowanie instytucji, op. cit., s. 133. 
ganowi właściwemu, zwłaszcza że $w$ dziale VIII k.p.a., który również wykonuje art. 63 Konstytucji, termin przekazania skargi lub wniosku organowi właściwemu następuje nie później niż w ciagu 7 dni (por. art. 231 i 243 k.p.a.).

Takich argumentów nie wskazano w uzasadnieniu senackiego projektu ustawy o petycjach (druk sejmowy nr 2135/VII kad.) ${ }^{32}$, a jednocześnie w trakcie prac legislacyjnych nad tym przedłożeniem w opiniach na jego temat zgłaszano zastrzeżenia co do omawianego terminu ${ }^{33}$.

Wobec powyższego postulat zmiany art. 6 ust. 1 ustawy zgłoszony w petycji jest w pełni zasadny.

\section{Podsumowanie}

Obie zmiany ustawy z 11 lipca 2014 r. o petycjach w zakresie proponowanym w petycji wydają się uzasadnione i są dopuszczalne z punktu widzenia swobody ustawodawcy. Za ich pozytywną oceną przemawia m.in. dotychczasowa praktyka i poglądy wyrażane w doktrynie.

Proponowana zmiana art. 8 ustawy uzyskała wcześniej rekomendację Biura Analiz Sejmowych ${ }^{34} \mathrm{z}$ uwagi na to, że taka nowelizacja służyłaby transparentności procesu postępowania z petycjami (m.in. w kontekście obywatelskiego prawa do informacji gwarantowanego w art. 61 Konstytucji RP) oraz likwidowałaby „nie-

31 E. Wójcicka, Ustawa z dnia 11 lipca 2014 r. o petycjach - uwagi krytyczne, „Ruch Prawniczy, Ekonomiczny i Socjologiczny” 2017, nr 1, s. 167.

32 Art. 7 projektu (czyli art. 6 ustawy) zawiera następujący fragment: Projekt ustawy przewiduje zasadę działania adresatów petycji w ramach ich właściwości, która powinna być ustalana stosownie do materii, której petycja dotyczy i zakresu kompetencji podmiotu niezbędnego do jej rozpatrzenia. Podmiot, do którego błędnie wniesiono petycję, jest obowiązany do przekazania jej właściwemu podmiotowi (art. 7).

33 M. Florczak-Wątor w Opinii prawnej na temat senackiego projektu ustawy o petycjach (druk nr 2135) z 7 kwietnia 2014 r. stwierdza: Poważne wątpliwości rodza również wskazane w projekcie terminy rozpatrzenia petycji. Wynikajacy $z$ art. 7 projektu termin maksymalny 30 dni na przekazanie petycji przez jej adresata do podmiotu właściwego do jej rozpatrzenia jest zbyt długi, zważywszy na to, że poza stwierdzeniem swej niewłaściwości adresat petycji na tym etapie postępowania nie podejmuje żadnych innych działań, zaś samo przekazanie petycji jest czynnością techniczną. Moim zdaniem wystarczajacy byłby termin maksymalny 7 dni, czyli taki sam jaki art. 231 i art. 243 k.p.a. ustanawiają dla czynności przekazywania organom właściwym skarg i wniosków do rozpatrzenia, http://orka.sejm.gov.pl/rexdomk7.nsf/Opdodr?OpenPage\&nr=2135. Podobna uwaga została zgłoszona w „Uwagach woj. opolskiego do senackiego projektu ustawy o petycjach” z dnia 30 stycznia 2014 r., http://orka.sejm.gov.pl/Druki7ka.ns f/0/468173F83ED010BFC1257C7D0044FEB7/\%24File/2135.pdf.

34 Opinia prawna dotyczaca petycji A.H. $z$ dnia 28 grudnia 2016 r. do Marszałka Sejmu w sprawie podjęcia działań w celu zmiany ustawy o petycjach, BAS-WAUiP 364/17. 
symetryczność" polegającą na obowiązku publikowania skanu petycji i braku takiego obowiązku w odniesieniu do odpowiedzi udzielonej wnoszącemu petycję.

Ponieważ w przypadku skarg i wniosków (rozpatrywanych na podstawie działu VIII k.p.a.) termin na przekazanie skargi (wniosku) według właściwości wynosi 7 dni, zasadne byłoby skrócenie takiego terminu również przy rozpatrywaniu petycji, np. do $14 \mathrm{dni}$ (czyli tak, jak to zaproponowano w petycji w ramach nowelizacji art. 6 ustawy).

$\mathrm{W}$ analizowanej petycji przedstawiono koncepcję legislacyjną, a w związku $\mathrm{z}$ tym postulaty zgłaszane przez jej autora mogą stanowić podstawę do podjęcia konkretnych prac nad zmianą prawa.

\section{Bibliografia}

Bernaczyk M., Postępowanie w przedmiocie rozpatrzenia petycji [w:] Teoretyczne i praktyczne aspekty realizacji prawa petycji, red. R. Balicki, M. Jabłoński, Wrocław 2015.

Borkowski J. [w:] B. Adamiak, J. Borkowski, Kodeks postępowania administracyjnego, Warszawa 2006.

Gajewski S., Jakubowski A., Petycje, skargi i wnioski, Dział VIII Kodeksu postępowania administracyjnego. Ustawa o petycjach. Komentarz, Warszawa 2015.

Galicki R., Wykorzystanie instytucji petycji, wniosków i skarg przez związki zawodowe analiza dogmatyczna [w:] Skargi, wnioski i petycje - powszechne środki ochrony prawnej, red. M. Błachucki, G. Sibiga, Wrocław 2017.

Gomułowicz A., Skoczylas A.P., Zakres znaczeniowy - sposób rozumienia „interesu społecznego" ( $w$ kontekście innych pojęć niedookreślonych stosowanych przez sądy administracyjne) [w:] Klauzule generalne $i$ zwroty niedookreślone w prawie podatkowym i administracyjnym, A. Choduń, A. Gomułowicz, A.P. Skoczylas, 2013, LEX.

Jabłoński M., Prawo dostępu do informacji publicznej a prawo petycji [w:] Teoretyczne i praktyczne aspekty realizacji prawa petycji, red. R. Balicki, M. Jabłoński, Wrocław 2015.

Kmieciak Z., Zarys teorii postępowania administracyjnego, 2014, LEX.

Ożóg M., Uregulowanie instytucji petycji w ustawie $z$ dnia 11 lipca 2014 r. o petycjach, „Przegląd Sejmowy” 2015, nr 5(130).

Pisz M., Gwarancje realizacji konstytucyjnego prawa do petycji w kontekście ustawy z dnia 11 lipca 2014 r. o petycjach, „Przegląd Legislacyjny” 2016, nr 2.

Preisner A., Kuczma P., Zakres przedmiotowy prawa petycji i jego ograniczenia [w:] Teoretyczne i praktyczne aspekty realizacji prawa petycji, red. R. Balicki, M. Jabłoński, Wrocław 2015.

Przybysz P.M., Kodeks postępowania administracyjnego. Komentarz, 2018, LEX.

Sybilski D., Zagadnienie jawności i dostęp do akt w postępowaniach uproszczonych $w$ sprawach skarg, wniosków i petycji [w:] Skargi, wnioski i petycje - powszechne środki ochrony prawnej, red. M. Błachucki, G. Sibiga, Wrocław 2017.

Wójcicka E., Ustawa z dnia 11 lipca 2014 r. o petycjach - uwagi krytyczne, „Ruch Prawniczy, Ekonomiczny i Socjologiczny" 2017, nr 1, https://doi.org/10.14746/rpeis.2017.79.1.12. 


\title{
Niepołączalność stanowisk członków organów jednostek pomocniczych w gminach ${ }^{1}$
}

\begin{abstract}
Incompatibility of positions in auxiliary units of communes (WAKiU-752/18): A danger of conflict of interests in case of election to a legislative or an executive body of an auxiliary unit exists both with regard to executive positions and all local self-government employees (including councillors). A prohibition of standing for a position in the legislative (or executive) body of the auxiliary unit by a local self-government officer is not admissible, because regulating human rights may be exclusively regulated by statutes. Introducing statutory provisions concerning a formal incompatibility may prevent such conflict of interests. Such problem (conflict of interests) does not exist in case when the local government officer resides and works in different communes.
\end{abstract}

Keywords: commune, auxiliaryunit, body of subsidiaryunits, councillor, incompatibility of post, local self-government

Słowa kluczowe: gmina, jednostka pomocnicza, organy jednostki pomocniczej, radny, niepołączalność stanowisk, samorząd terytorialny

\section{Przedmiot opinii}

Przedmiotem opinii jest propozycja ustanowienia zabezpieczenia prawnego przed powstawaniem konfliktu interesów w następstwie wyboru urzędnika samorządowego mieszkającego w gminie, w której pracuje, do organu uchwałodawczego (ale i wykonawczego) jednostki pomocniczej.

Opinia prawna na temat niepołązalności stanowisk członków organów jednostek pomocniczych w gminach sporządzona 20 kwietnia 2018 r. na zlecenie posła Klubu Parlamentarnego Prawo i Sprawiedliwość; BAS-WAKiU 752/18. 


\section{Uzasadnienie}

Uważam, że podniesiony problem odnośnie do możliwości ustanawiania zakazu zasiadania przez urzędników samorządowych w radach dzielnic dotyczy generalnie organów uchwałodawczych wszystkich jednostek pomocniczych (oczywiście również do organów wykonawczych) i dlatego w opinii odnoszę się do tego zagadnienia niezależnie od nazwy jednostki pomocniczej.

Opinię rozpocząć należy od przypomnienia, że podstawę prawną istnienia i działania jednostek pomocniczych $\mathrm{w}$ gminie formułuje art. 5 ust. 1 ustawy z 8 marca 1990 r. o samorządzie gminnym (t.j. Dz.U. 2016, poz. 446, ze zm.; dalej: u.s.gm.). Stanowi on, że gmina może tworzyć jednostki pomocnicze: solectwa oraz dzielnice, osiedla i inne (zdanie pierwsze); przewiduje ponadto, że jednostką pomocniczą może być również położone na terenie gminy miasto. Obowiązek tworzenia dzielnic jako jednostek pomocniczych przewiduje jedynie art. 5 ust. 1 ustawy z 15 marca 2002 r. o ustroju miasta stołecznego Warszawy (t.j. 2015, poz. 1438, ze zm.). Pokazuje to olbrzymią różnorodność jednostek pomocniczych, samo bowiem wyliczenie ich nazw jest jedynie przykładowe. Dlatego też w praktyce stosowane są również takie nazwy jak: kolonia, przysiółek, sioła, okręgi, obwody, rewiry czy kwartał, a nawet miejscowość 2 .

Jednostki pomocnicze są tym samym bardzo zróżnicowane nie tylko pod względem nazwy, ale przede wszystkim wielkości, tak z uwagi na liczbę mieszkańców, jak i na obszar. Nie może to jednak zaskakiwać, skoro niezwykle zróżnicowane są same gminy - od małych, wiejskich, co najwyżej kilkutysięcznych, $\mathrm{w}$ których siedziba nie ma nawet statusu miasta, poprzez miejsko-wiejskie, których „miejskość" przejawia się w tym, że siedziba ich władz położona jest w miejscowości posiadającej prawa miejskie, jednak z dominującymi obszarami o klasycznym wiejskim charakterze, po gminy obejmujące obszar wyłącznie miejscowości posiadającej prawa miejskie, a także wielkie kilkusettysięczne miasta, a w przypadku Warszawy nawet metropolię zamieszkałą przez ponad 1,7 mln mieszkańców.

Sołectwa czy przysiółki to jednostki pomocnicze tworzone tradycyjnie na terenach wiejskich, często uwzględniające ich historyczną przeszłość czy wręcz odrębność, w czym widoczne są również względy sentymentalne, natomiast rzadziej względy natury praktycznej. Już same te nazwy podkreślają, że są to jednostki niewielkie zwłaszcza pod względem liczby mieszkańców. Dla miast właściwsze jest nazywanie jednostek pomocniczych osiedlami czy nawet dzielnicami, co

2 Zob. D. Tyrawa [w:] Samorząd gminny w III Rzeczypospolitej. Doświadczenia i perspektywy, red. M. Klimek, J. Czerw, B. Więckiewicz, Lublin 2013, s. 121; B. Jaworska-Dębska, Uwaga 2 do art. 5 [w:] Ustawa o samorzadzie gminnym. Komentarz, red. P. Chmielnicki, Warszawa 2013, s. 130-131; Komentarz do art. 5 ustawy $z$ dnia 8 marca 1990 r. o samorządzie gminnym (Dz.U.01.142.1591) [w:] G. Jyż, Z. Pławecki, A. Szewc, Samorząd gminny. Komentarz, Warszawa 2005. 
w szczególności w tym drugim przypadku podkreśla, że są to jednostki większe tak pod względem obszaru, jak i liczby mieszkańców. Konsekwencją obowiązującej ustawowej regulacji jednostek pomocniczych jest zatem to, że będące nimi osiedla czy dzielnice w dużych miastach na prawach powiatu (jak np. Kraków czy Łódź) są większe od niejednej ledwie kilkutysięcznej gminy wiejskiej.

Ustawa o samorządzie gminnym przesądza, że jednostki pomocnicze mają swoje organy uchwałodawcze (stanowiące i kontrolne) oraz wykonawcze. Zgodnie z tymi postanowieniami organami tymi są: w sołectwie - zebranie wiejskie jako organ uchwałodawczy i sołtys (wspomagany przez radę sołecką) jako organ wykonawczy (art. 36 ust. 1 i 2 u.s.gm.), natomiast w dzielnicy czy osiedlu - rada osiedla jako organ uchwałodawczy oraz zarząd na czele z przewodniczącym jako organ wykonawczy (art. 37 ust. 1 i 2 u.s.gm.), przy czym w statucie osiedla nadawanym przez radę gminy może być ustalone, że w osiedlu organem uchwałodawczym jest ogólne zebranie mieszkańców (art. 37 ust. 4 u.s.gm.).

W opinii pomijam kwestie odnoszące się do liczebności rady dzielnicy (osiedla), jak i organizacji nienazwanych w ustawie o samorządzie gminnym jednostek pomocniczych. Zastrzegam jednak, że dalsze rozważania odnoszące się do organów jednostek pomocniczych nazwanych w ustawie dotyczą również organów jednostek pomocniczych w ustawie nienazwanych.

Pojawiało się podejrzenie, że w przypadku - jak rozumiem - wszystkich pracowników samorządowych może pojawić się kolizja interesów, jeżeli zostaną wybrani w skład organu uchwałodawczego jednostki pomocniczej. Uważam, że jest to obawa w pełni zasadna, przy czym w szczególności możliwe jest wywieranie nacisku na pracownika ze strony wójta (burmistrza, prezydenta miasta). Problem konfliktu interesów jeszcze wyraźniej występuje w przypadku radnego, który zostaje przewodniczącym jednostki pomocniczej. Jest oczywiście zrozumiałe, że podniesiony problem nie dotyczy sytuacji, w której urzędnik samorządowy mieszka w innej gminie a pracuje w innej, gdyż wówczas konflikt interesów nie wystąpi. W niektórych statutach jednostek pomocniczych ustanawiany jest zakaz kandydowania do tych organów przez osoby zajmujące kierownicze stanowiska w urzędzie gminy (miasta). Czy ograniczenia takiego nie można rozszerzyć na wszystkich pracowników samorządowych oraz czy można uczynić to jedynie w statutach jednostek pomocniczych, czy niezbędna jest nowelizacja ustawy o pracownikach samorządowych bądź innej ustawy?

Odnosząc się do tego pytania i postulatu, przede wszystkim chciałbym wskazać na zdecydowanie zbyt lakoniczne, a przy tym również niezrozumiałe bardzo odmienne uregulowania dotyczące z jednej strony wyboru sołtysa i rady sołeckiej, a z drugiej strony wyboru organów innych jednostek pomocniczych. Przypomnę, że zgodnie z art. 36 ust. 2 u.s.gm.: [s] ołtys oraz członkowie rady sołeckiej wybierani sa $w$ głosowaniu tajnym, bezpośrednim, spośród nieograniczonej liczby kandydatów, przez stałych mieszkańców sołectwa uprawnionych do głosowania. Z kolei w przypadku wyboru organów innych jednostek art. 35 ust. 3 pkt. 2 
tej ustawy, nakładając na radę gminy obowiązek uchwalenia statutu jednostki pomocniczej, nakazuje jednocześnie w szczególności zamieścić w nim „zasady i tryb wyborów organów jednostek pomocniczych”. Nie jest dla mnie zrozumiałe, dlaczego w przypadku sołtysa i rady sołeckiej zasady ich wyboru określone są wprost $\mathrm{w}$ ustawie, natomiast w przypadku wyboru organów innych jednostek pomocniczych istnieje odesłanie do regulacji w statucie jednostki pomocniczej. Za niedopuszczalne uważam przy tym regulowanie zasad wyboru organów jednostki pomocniczej w statucie.

W literaturze przedmiotu od lat podnosi się, że w praktyce określanie w statutach zasad i trybu wyboru organów jednostki pomocniczej budzi wątpliwości. Barbara Jaworska-Dębska bardzo trafnie podnosi przy tym: Niewątpliwie punktem wyjścia dla ustaleń tego, co jest $w$ tej materii $w$ statucie prawnie dopuszczalne, jest przyjęcie tezy, że określenie w statucie jednostki pomocniczej zasad i trybu wyborów organów jednostki pomocniczej musi się mieścić w ramach wyznaczonych przepisami ustawy o samorzadzie gminnym oraz Kodeksu wyborczego i musi te unormowania respektować bez możliwości jakiejkolwiek modyfikacji. Ustawy określaja podstawowy katalog zasad prawa wyborczego organów jednostek pomocniczych, natomiast w statucie jednostki pomocniczej powinny się znaleźć wszystkie zasady szczegółowe. Z tego powodu statut jednostki pomocniczej nie może zawierać nowych, dodatkowych zasad prawa wyborczego, a jedynie uszczegółowienie istniejących. W związku z powyższym należy uznać, że w statucie sołectwa - w ramach określania zasad i trybu wyborów organów sołectwa - jest miejsce na ustalenie form $i$ trybu, w jakim powinny być zgłoszone kandydatury sołtysa i członków rady sołeckiej (...). W statucie jednostki pomocniczej jest też miejsce na określenie długości kadencji wybieranych organów oraz wskazanie, że po upływie kadencji działaja one do dnia ogłoszenia wyników wyborów nowych organów ${ }^{3}$.

Przede wszystkim uważam, że niedopuszczalne jest pozbawianie w statucie jednostki pomocniczej możliwości kandydowania przez radnych (bądź kogokolwiek innego) w wyborach do organów jednostek pomocniczych. Prawa człowieka należą do wyłącznej materii ustawowej, stąd statut absolutnie nie jest aktem prawnym - i to nawet w sytuacji, gdy jest prawem miejscowym powszechnie obowiązującym - do ustanawiania takiego ograniczenia. Gdyby miało być ono ustanowione, to aktami prawnymi, w których byłoby możliwe dokonanie tego, wydają się być Kodeks wyborczy lub ustawa o samorządzie gminnym. Drugi z tych aktów wydaje się nawet bardziej właściwy, gdyż to w nim uregulowana jest kwestia istnienia jednostek pomocniczych, określone są ich organy uchwałodawcze i wykonawcze, tam wreszcie zawarte jest sygnalizowane niezbyt szczęśliwe przesądzenie o regulowaniu przez statut jednostki pomocniczej zasad i trybu wyboru jej organów.

3 B. Jaworska-Dębska, Uwaga 3a do art. 35 [w:] Ustawa o samorządzie gminnym. Komentarz, red. P. Chmielnicki, Warszawa 2013, s. 546. 
Jestem jednak zdania, że w celu uniknięcia konfliktu interesów, które legły u podłoża powstania tej opinii, zamiast pozbawienia prawa kandydowania zdecydowanie właściwszym rozwiązaniem jest ustawowe wprowadzenie niepołączalności formalnej, a więc zakazu łączenia mandatu z określonymi funkcjami bądź stanowiskami. Nie dojdzie tym samym do pozbawienia osoby prawa kandydowania, lecz zostanie pozostawienie jej możliwości wyboru, czy chce nadal pracować jako urzędnik samorządowy, czy też być członkiem organu uchwałodawczego bądź wykonawczego jednostki pomocniczej. Jest to możliwe przykładowo poprzez uzupełnienie art. 25b u.s.gm. o pkt 4, zgodnie z którym mandatu radnego nie będzie można łączyć z członkostwem w organie jednostki pomocniczej gminy. Jednak przede wszystkim powinny zostać w stosowny sposób rozbudowane przepisy ustawy o samorządzie gminnym odnoszące się do wyborów organów uchwałodawczych i wykonawczych jednostek pomocniczych.

Z uwagi na treść pytania pragnę również stwierdzić, że, moim zdaniem, miejscem na ustanowienie wskazanej zasady niepołączalności stanowisk nie powinna być ustawa z 21 listopada 2008 r. o pracownikach samorządowych (t.j. Dz.U. 2016, poz. 902, ze zm.), gdyż dotyczy ona kwestii stricte związanych z zatrudnieniem. Gdyby jednak stosowny przepis miał się w niej znaleźć, to uważam, że powinno zostać to umieszczone w rozdziale 3 o obowiązkach pracownikach samorządowych, po art. 32 ustanawiającym wymóg złożenia oświadczenia majątkowego.

\section{Podsumowanie}

- Nie tylko w odniesieniu do osób na stanowiskach kierowniczych, lecz do wszystkich pracowników samorządowych (jak i radnych gminy) istnieje niebezpieczeństwo występowania konfliktu interesów w przypadku ich wyboru do organu uchwałodawczego lub wykonawczego jednostki pomocniczej.

- Konflikt interesów będzie mieć miejsce również w przypadku wyboru radnego gminy do organu uchwałodawczego lub wykonawczego jednostki pomocniczej.

- Niedopuszczalne jest ustanawianie zakazu kandydowania urzędnika samorządowego do organu uchwałodawczego (bądź wykonawczego) jednostki pomocniczej w statucie jednostki pomocniczej, gdyż prawa człowieka należą do wyłącznej materii ustawowej.

- Zakaz kandydowania pracowników samorządowych w wyborach do organów jednostki pomocniczej nie jest właściwym sposobem zapobieżenia wystąpienia konfliktu interesów w przypadku zdobycia przez nich mandatu.

- Zapobiec wystąpieniu konfliktu interesów w przypadku zdobycia przez urzędnika samorządowego mandatu w organie uchwałodawczym lub wykonawczym jednostki pomocniczej może ustawowe wprowadzenie niepołączal- 
ności formalnej. Rozwiązanie takie powinno zostać uregulowane w ustawie o samorządzie gminnym, nie wydaje się natomiast właściwe, aby zostało zawarte w ustawie o pracownikach samorządowych.

- Jest zrozumiałe, że podniesiony problem nie dotyczy sytuacji, w której urzędnik samorządowy mieszka w innej gminie niż ta, w której pracuje, gdyż wówczas konflikt interesów nie wystąpi.

\section{Bibliografia}

Jaworska-Dębska B., Uwaga 2 do art. 5; uwaga 3a do art. 35 [w:] Ustawa o samorządzie gminnym. Komentarz, red. P. Chmielnicki, Warszawa 2013.

Jyż G., Pławecki Z., Szewc A., Samorząd gminny. Komentarz, Warszawa 2005.

Tyrawa D., Jednostki pomocnicze gminy [w:] Samorzad gminny w III Rzeczypospolitej. Doświadczenia i perspektywy, red. M. Klimek, J. Czerw, B. Więckiewicz, Lublin 2013. 



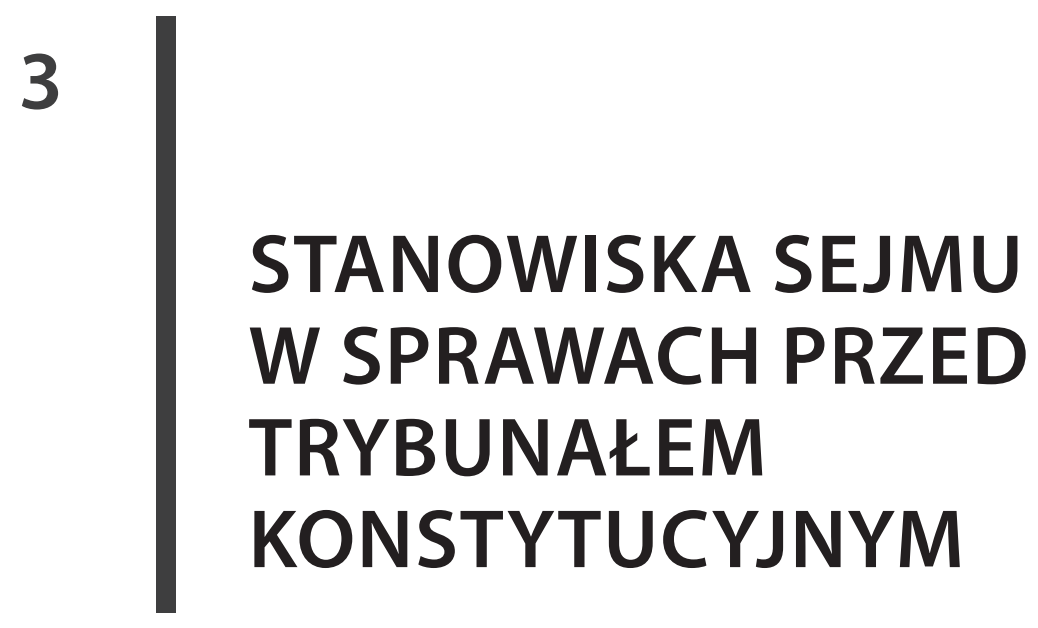





\section{Ocena zgodności z Konstytucją art. 7673a Kodeksu postępowania cywilnego w zakresie, w jakim nie przewiduje skargi na orzeczenie referendarza w przedmiocie skargi na czynności komornika sądowego ${ }^{1}$}

Assessment of conformity to the Constitution of Article $767^{3 \mathrm{a}}$ of the Code of Civil Procedure as regards the lack of possibility to appeal against a court referendary's decision regarding complaint regarding bailiff's activities (WPTK-2642/17): According to the author of the proposed Sejm's draft position the indicated provision, being the subject of the Warsaw District Court's question of law, conforms to the Constitution. Court referendaries perform tasks related to legal protection, other than in administration of justice. In case of filling a complaint against a court referendary's decision in enforcement proceedings, the court shall hear the case as a court of second instance, in accordance with the provisions on appeals. The complaint against the decision may be appealed only in cases, in which a court decision may be appealed. Proceeding complaints against bailiff's activities does not constitute "a case" with the meaning of Article 45 para. 1 of the Constitution. The legal norm, pursuant to which it is not possible to appeal against the court referendary's decision on the complaint regarding bailiff's activities, does not infringe the constitutional principle of procedural /justice.

Keywords: enforcement proceedings, Code of Civil Procedure, Constitutional Tribunal

Słowa kluczowe: egzekucja, Kodeks postępowania cywilnego, Trybunał Konstytucyjny

Doktor hab. nauk prawnych, adiunkt w Katedrze Prawa Gospodarczego Uniwersytetu Jagiellońskiego, radca prawny, ekspert ds. legislacji BAS; marcin.spyra@uj.edu.pl.

Na podstawie art. 69 ust. 2 w związku z art. 42 pkt 3 ustawy z dnia 30 listopada 2016 r. o organizacji i trybie postępowania przed Trybunałem Konstytucyjnym (Dz. U. poz. 2072), w imieniu Sejmu Rzeczypospolitej Polskiej przedkładam wyjaśnienia w sprawie pytania prawnego Sądu Rejonowego dla Warszawy-Pragi

1 Projekt stanowiska sporządzony 14 czerwca 2018 r., sygn. akt P 21/17; BAS-WPTK 2642/17. 
Południe w Warszawie, I Wydział Cywilny z 3 października 2017 r. (sygn. akt P 21/17), jednocześnie wnosząc o stwierdzenie, że art. $767^{3 a}$ zdanie pierwsze ustawy z dnia 17 listopada 1964 r. - Kodeks postępowania cywilnego (t.j. Dz. U. 2018, poz. 155, ze zm.) w zakresie, w jakim nie przewiduje skargi na orzeczenie referendarza w przedmiocie skargi na czynności komornika sądowego, jest zgodny $\mathrm{z}$ art. 45 ust. 1 Konstytucji.

Ponadto wnoszę o umorzenie postępowania w pozostałym zakresie na podstawie art. 59 ust. 1 pkt 2 ustawy o organizacji i trybie postępowania przed Trybunałem Konstytucyjnym ze względu na niedopuszczalność wydania wyroku.

\section{Uzasadnienie}

\section{Przedmiot kontroli i zarzuty pytającego sądu}

1. Przedmiotem kontroli jest art. $767^{3 \mathrm{a}}$ zdanie pierwsze ustawy z dnia 17 listopada 1964 r. - Kodeks postępowania cywilnego (t.j. Dz. U. 2018, poz. 155, ze zm.; dalej: k.p.c.) w brzmieniu następującym: „Skarga na postanowienie referendarza sądowego przysługuje w przypadkach, w których na postanowienie sądu przysługuje zażalenie. Wniesienie skargi nie powoduje utraty mocy przez zaskarżone postanowienie referendarza sądowego. Sąd rozpoznaje skargę w składzie jednego sędziego, jako sąd drugiej instancji, stosując odpowiednio przepisy o zażaleniu. Rozpoznając skargę, sąd wydaje postanowienie, w którym zaskarżone postanowienie referendarza sądowego utrzymuje w mocy albo je zmienia”.

2. Pytanie prawne leżące u podstaw analizowanej sprawy zostało sformułowane w związku z postępowaniem toczącym się przed Sądem Rejonowym dla Warszawy-Pragi Południe w Warszawie, I Wydział Cywilny (dalej: sąd pytający) w sprawie o sygn. akt I Co 970/17. Postępowanie to dotyczy postanowienia referendarza sądowego przy Sądzie Rejonowym dla Warszawy-Pragi Południe, który rozstrzygając skargę dłużnika W.M. na czynności komornika sądowego przy Sądzie Rejonowym w Piotrkowie Trybunalskim podjęte w postępowaniu egzekucyjnym prowadzonym na wniosek wierzycieli T.P., J.P. oraz M.Ś. uchylił zaskarżone czynności. Skargę na to postanowienie wnieśli wierzyciele. Zgodnie $\mathrm{z}$ obowiązującym stanem prawnym sąd pytający, działając na podstawie art. $398^{22} \S 5 \mathrm{w}$ związku $\mathrm{z}$ art. $767^{3 \mathrm{a}}$ zdanie pierwsze, art. $767^{4} \S 1$ oraz art. $13 \$ 2$ k.p.c., powinien odrzucić skargę wierzycieli jako niedopuszczalną. Sąd pytający powziął jednak wątpliwości co do zgodności art. $767^{3 \mathrm{a}}$ zdanie pierwsze k.p.c. „W zakresie, w jakim na orzeczenie referendarza sądowego nie przysługuje skarga” z art. 45 ust. 1 oraz 78 Konstytucji i wobec tego skierował na podstawie art. 193 Konstytucji pytanie prawne do Trybunału Konstytucyjnego, które rozpoczęło postępowanie w niniejszej sprawie.

3. Zdaniem sądu pytającego regulacja ustawowa, zgodnie z którą referendarz sądowy wydaje ostateczną decyzję w sprawie inicjowanej skargą na czynności 
komornika, jest nie do pogodzenia $\mathrm{z}$ art. 45 ust. 1 Konstytucji, gwarantującym każdemu prawo do sprawiedliwego i jawnego rozpatrzenia sprawy bez nieuzasadnionej zwłoki przez właściwy, niezależny, bezstronny i niezawisły sąd. Sąd pytający stoi na uznanym w orzecznictwie Trybunału Konstytucyjnego stanowisku, że referendarz sądowy ani nie jest sądem w rozumieniu art. 45 ust. 1 Konstytucji $\mathrm{RP}$, ani nie sprawuje wymiaru sprawiedliwości. Powierzenie referendarzowi rozstrzygania określonej sprawy nie realizuje $\mathrm{w}$ związku z tym podmiotowego prawa do sądu wynikającego $\mathrm{z}$ art. 45 ust. 1 Konstytucji. Prawo to może być zrealizowane dopiero przez umożliwienie poddania orzeczenia referendarza kontroli ze strony sądu. Brak możliwości takiej kontroli ze swej istoty narusza art. 45 ust. 1 Konstytucji. Zdaniem sądu pytającego art. $767^{3 a}$ zdanie pierwsze k.p.c. „w zakresie, w jakim na orzeczenie referendarza sądowego nie przysługuje skarga" stoi także w sprzeczności z art. 78 Konstytucji, który gwarantuje każdej ze stron możliwość zaskarżenia orzeczeń i decyzji wydanych w pierwszej instancji. W tym kontekście sąd pytający wskazuje, że istotą pytania prawnego nie jest zarzut naruszenia zasady dwuinstancyjności postępowania, ale ocena dopuszczalności sprawowania przez referendarzy sądowych nadzoru nad organami egzekucyjnymi bez możliwości kontroli rozstrzygnięć referendarzy przez sąd, co narusza istotę prawa podmiotowego wskazanego w art. 78 Konstytucji. Prawa wynikające $\mathrm{z}$ art. 45 ust. 1 oraz art. 78 Konstytucji nie mają charakteru absolutnego i mogą doznawać ograniczeń. Dostatecznym uzasadnieniem dla takich ograniczeń nie mogą być jednak, zdaniem sądu pytającego, korzyści, jakie płyną z przyspieszenia postępowania dotyczącego nadzoru nad organami egzekucyjnymi.

\section{Analiza formalnoprawna}

1. Przedstawione pytanie spełnia jedynie częściowo wynikające z art. 193 Konstytucji przesłanki formalne dopuszczalności związane ze specyfiką instytucji pytania prawnego jako jednego ze sposobów inicjowania postępowania przed Trybunałem Konstytucyjnym. Z art. 193 Konstytucji wynika, że:

- pytanie prawne może być zadane wyłącznie przez sąd w rozumieniu art. 175 Konstytucji (zob. postanowienie TK z 4 października 2010 r., sygn. akt P 12/08,), czyli państwowy organ władzy sądowniczej, oddzielony i niezależny od władzy ustawodawczej i wykonawczej (zob. postanowienie TK z 27 kwietnia 2004 r., sygn. akt P 16/03) - tzw. przesłanka podmiotowa,

- przedmiotem pytania prawnego może być zgodność każdego aktu normatywnego (a więc aktu zawierającego normy prawne o charakterze generalnym i abstrakcyjnym; zob. postanowienie TK z 29 marca 2000 r., sygn. akt P 13/99) $\mathrm{z}$ przepisami, które mają wyższą rangę $\mathrm{w}$ hierarchicznym systemie prawa niż akt normatywny poddawany kontroli ( $w$ zależności od sytuacji, mogą to być przepisy Konstytucji, ratyfikowanej umowy międzynarodowej lub ustawy; zob. np. postanowienie TK z 6 października 2009 r., sygn. akt P 77/08) - tzw. przesłanka przedmiotowa, 
- od odpowiedzi na pytanie prawne musi zależeć rozstrzygnięcie konkretnej sprawy toczącej się przed sądem pytającym (zob. np. postanowienia TK z: 22 października 2007 r., sygn. akt P 24/07, oraz z 15 kwietnia 2008 r., sygn. akt P 26/07); w orzecznictwie TK wskazywano przy tym, że przedmiotem sprawy może być wyłącznie przepis (proceduralny, materialnoprawny lub kompetencyjny), który powinien być zastosowany przez sąd w toczącym się postępowaniu i na podstawie którego sąd jest zobowiązany wydać stosowne orzeczenie, a więc przepis, który będzie stanowił podstawę rozstrzygnięcia (zob. przywołane wyżej postanowienie TK w sprawie o sygn. akt P 12/08 i postanowienia TK z: 27 lutego 2008 r., sygn. akt P 31/06, oraz 19 października 2011 r., sygn. akt P 42/10) - tzw. przesłanka funkcjonalna.

Istota związku między postępowaniem prowadzonym przez sąd pytający a postępowaniem zainicjowanym pytaniem prawnym powinna polegać zatem na tym, że sąd pytający nie mógłby rozstrzygnąć sprawy bez uzyskania odpowiedzi dotyczącej konstytucyjności przepisu będącego przedmiotem postępowania (zob. m.in. postanowienia TK z: 14 grudnia 2004 r., sygn. akt P 32/02; 26 maja 2008 r., sygn. akt P 14/05; 5 kwietnia 2017 r., sygn. akt P 17/16; 25 maja 2017 r., sygn. akt P 43/13). Znaczenie przesłanki funkcjonalnej jest podkreślone w art. 52 ust. 2 pkt 5 ustawy z dnia 30 listopada 2016 r. o organizacji i trybie postępowania przed Trybunałem Konstytucyjnym (Dz. U. poz. 2072; dalej: ustawa o organizacji i trybie postępowania przed TK), zgodnie z którym pytanie prawne powinno wyjaśniać, „w jakim zakresie odpowiedź na pytanie może mieć wpływ na rozstrzygnięcie sprawy, w związku z którą (...) zostało przedstawione”.

2. Spełnienie przesłanki podmiotowej i przedmiotowej w niniejszej sprawie jest bezsporne. Spełnienie przesłanki funkcjonalnej budzi natomiast istotne wątpliwości ze względu na zakres, w jakim sąd pytający wnosi o zbadanie konstytucyjności art. $767^{3 a}$ zdanie pierwsze k.p.c. Sąd pytający wniósł o zbadanie, czy przepis ten jest zgody z art. 45 ust. 1 oraz z art. 78 Konstytucji „w zakresie, w jakim na orzeczenie referendarza sądowego nie przysługuje skarga”. Tak sformułowane pytanie prawne implikuje konieczność zbadania zgodności z powołanymi przez sąd pytający wzorcami konstytucyjnymi wszystkich przypadków, w których w postępowaniu egzekucyjnym na orzeczenie referendarza sądowego nie przysługuje skarga. Jest to ponad dwadzieścia przypadków, o różnym charakterze prawnym, różnej materii rozstrzygnięcia oraz różnym schemacie proceduralnym. W niektórych $\mathrm{z}$ nich rozstrzygnięcie referendarza dotyczy praw i obowiązków dłużnika, wierzyciela lub innych osób (np. wyznaczenie kuratora dla dłużnika nieznanego z miejsca pobytu - art. 802 k.p.c., zgody na wydzierżawienie zajętej nieruchomości - art. 936 k.p.c., utrzymania w mocy służebności gruntowej na sprzedawanej nieruchomości - art. 1001 k.p.c.). W innych orzeczenia referendarza mają niewątpliwie charakter wpadkowy i akcesoryjny w stosunku do głównego toku postępowania, odnosząc się do czysto procedu- 
ralnych i technicznych aspektów egzekucji (np. określenie trybu wyszukania nabywcy $\mathrm{z}$ wolnej ręki nieruchomości - art. $1013^{3} \$ 1$ in fine k.p.c., skierowanie egzekucji z nieruchomości do trybu zwykłego w razie stwierdzenia braku przesłanek dla egzekucji uproszczonej - art. $1013^{5} \$ 4$ k.p.c.). Zbadanie zgodności art. $767^{3 \mathrm{a}}$ zdanie pierwsze k.p.c. w takim zakresie, w jakim wniósł o to sąd pytający, wymagałoby odrębnej analizy każdego z przypadków orzeczenia wydawanego przez referendarza, od którego na podstawie badanego przepisu nie przysługuje skarga do sądu. Każdy z tych przypadków jest bowiem inny, zarówno jeżeli chodzi o materię rozstrzygnięcia, jak też jego proceduralne usytuowania $\mathrm{w}$ toku postępowania egzekucyjnego. Badanie takie musiałoby ustalić m.in., czy dane rozstrzygnięcie referendarza dotyczy „sprawy” w rozumieniu art. 45 ust. 1 Konstytucji, czy orzeczenie to ma charakter pierwszoinstancyjny w rozumieniu art. 78 Konstytucji, czy materia rozstrzygnięcia może być poddana kontroli sądu $\mathrm{w}$ ramach innego postępowania niż skarga na postanowienie referendarza, czy poddanie danego rozstrzygnięcia kontroli sądu jest niezbędną przesłanką sprawiedliwości proceduralnej postępowania egzekucyjnego jako całości itd. Nie da się bowiem a limine wykluczyć, że wyłączenie możliwości sądowej weryfikacji orzeczeń referendarza jest sprzeczne z powołanymi wzorcami konstytucyjnymi jedynie w niektórych przypadkach, w pozostałych zaś np. ze względu na charakter sprawy, której dotyczy rozstrzygnięcie, jest z nimi zgodne. Co jednak kluczowe w perspektywie oceny dopuszczalności pytania prawnego, to tak wskazany zakres kontroli zbliżałby niniejsze postępowanie do kontroli abstrakcyjnej, oderwanej od okoliczności konkretnego przypadku i kontekstu, w jakim sąd stosuje (będzie stosował) zakwestionowany przepis.

Tak szerokie badanie konstytucyjności art. $767^{3 \mathrm{a}}$ zdanie pierwsze k.p.c. nie jest konieczne z punktu widzenia rozstrzygnięcia sprawy toczącej się przed sądem pytającym. Sprawa tocząca się przed sądem pytającym dotyczy wyłącznie problemu dopuszczalności wniesienia skargi na postanowienie referendarza w przedmiocie rozstrzygnięcia skargi na czynności komornika (art. 767 k.p.c.). Tylko w tym zakresie realizacja przesłanki funkcjonalnej z art. 193 Konstytucji została wystarczająco wykazana przez sąd pytający. Rozstrzygnięcie o dopuszczalności wniesienia skargi na postanowienie referendarza rozstrzygające skargę na czynności komornika wymaga zastosowania art. $767^{3 a}$ k.p.c. jako przepisu, który pośrednio określa zakres dopuszczalności wniesienia skargi inicjującej postępowanie przed sądem pytającym. Dopuszczalność zastosowania środka zaskarżenia w postępowaniu cywilnym zależy od istnienia przepisu, który stanowi, że od danego rodzaju orzeczenia przysługuje środek zaskarżenia (zob. np. K. Markiewicz [w:] Kodeks postępowania cywilnego. Komentarz, t. II, red. A. Marciniak, K. Piasecki, Warszawa 2016, komentarz do art. 398 22 , nb 4). W zakresie, w jakim art. $767^{3 a}$ k.p.c. nie dopuszcza wniesienia skargi na orzeczenie referendarza w postępowaniu egzekucyjnym, sąd jest zobowiązany taką skargę odrzucić (art. $398^{22}$ $\$ 5$ k.p.c. w związku z art. $13 \$ 2$ k.p.c.). Ewentualne uznanie, że art. $767^{3 a}$ k.p.c. 
jest niezgodny z art. 45 ust. 1 lub art. 78 Konstytucji „W zakresie, w jakim nie przewiduje skargi na orzeczenie referendarza w przedmiocie skargi na czynności komornika sądowego" wpłynęłoby na rozstrzygnięcie sądu w ten sposób, że skarga złożona przez wierzycieli nie zostałaby odrzucona, ale rozpoznana merytorycznie (art. $767^{3 a}$ zdanie trzecie k.p.c.). Tylko w takim zakresie istnieje zależność między wynikiem kontroli konstytucyjności art. $767^{3 \mathrm{a}} \mathrm{zdanie}$ pierwsze k.p.c. a rozstrzygnięciem toczącej się przed sądem pytającym sprawy o sygn. akt I Co 970/17. W zakresie, w jakim pytanie sformułowane w niniejszej sprawie dotyczy zastosowania art. $767^{3 a}$ zdanie pierwsze k.p.c. do wszystkich innych sytuacji, w których referendarz sądowy jest upoważniony do wydania postanowienia lub zarządzenia, na które nie przysługuje skarga, odpowiedź na pytanie prawne nie jest konieczna do wydania rozstrzygnięcia w rozpoznawanej przez sąd pytający sprawie. Przesądza to o niespełnieniu w tym zakresie przesłanki funkcjonalnej wynikającej z art. 193 Konstytucji.

Wydanie wyroku przez Trybunał Konstytucyjny jest zatem dopuszczalne jedynie w zakresie, w jakim zastosowanie art. $767^{3 a}$ zdanie pierwsze k.p.c. dotyczy braku możliwości wniesienia skargi na postanowienie referendarza dotyczące skargi na czynności komornika. W pozostałym zakresie merytoryczne rozpoznanie pytania prawnego jest niedopuszczalne, co implikuje konieczność umorzenia postępowania na podstawie art. 59 ust. 1 pkt 2 ustawy o organizacji i trybie postępowania przed TK.

3. Dopuszczalność wydania orzeczenia w postępowaniu zainicjowanym pytaniem prawnym zależy także od spełnienia przez postanowienie sądu pytającego wymogów wskazanych w art. 52 ust. 2 ustawy o organizacji i trybie postępowania przed TK. Zdaniem Sejmu sąd pytający nie spełnił wymogu uzasadnienia zarzutu sprzeczności art. $767^{\text {3a }}$ k.p.c. - w zakresie wskazanym wyżej - z art. 78 Konstytucji i nie powołał argumentów lub dowodów na poparcie sformułowanego zarzutu.

Wymóg uzasadnienia przez inicjatora postępowania zarzutu niekonstytucyjności wynika de lege lata $\mathrm{z}$ art. 52 ust. 2 pkt 4 ustawy o organizacji i trybie postępowania przed TK. Treść tego wymogu oraz jego znaczenie proceduralne zostały szczegółowo wyjaśnione w orzecznictwie TK. W tym zakresie aktualność zachowują m.in. poglądy Trybunału zawarte w uzasadnieniach orzeczeń dotyczących art. 32 ust. 1 pkt 4 ustawy z 1 sierpnia 1997 r. o Trybunale Konstytucyjnym (Dz. U. Nr 102, poz. 643, ze zm.); art. 63 ust. 2 pkt 3 ustawy z 22 lipca 2015 r. o Trybunale Konstytucyjnym (Dz. U. poz. 1157, ze zm.). Trybunał niejednokrotnie wskazywał, że „pytanie prawne powinno spełniać podstawowe wymagania formalne pism procesowych, do których należy m.in. uzasadnienie postawionego zarzutu niezgodności zakwestionowanego aktu normatywnego z Konstytucją, wraz z powołaniem dowodów na jego poparcie. Wynika to z obowiązującej zasady domniemania konstytucyjności aktu prawnego. W związku z obowiązywaniem tego domniemania podmiot inicjujący postępowanie przed 
Trybunałem Konstytucyjnym jest zobligowany dostarczyć argumentów pozwalających obalić to domniemanie. Dopóki sąd nie przedstawi przekonywujących motywów mających świadczyć o niezgodności kwestionowanego przepisu ze wskazanymi wzorcami kontroli, należy je uznawać za zgodne z wzorcem kontroli. Pytanie prawne, w którym sąd ograniczyłby się do wyrażenia przekonania o niezgodności przepisu z Konstytucją bądź wskazania istniejących w tej kwestii wątpliwości, nie może podlegać rozpoznaniu przez TK. Wskazanie wzorca kontroli bez szczegółowego odniesienia się do niego w uzasadnieniu lub zdawkowa redakcja zarzutu niekonstytucyjności nie może zostać uznana za „uzasadnienie postawionego zarzutu, z powołaniem dowodów na jego poparcie”. Odnosząc się do charakteru uzasadnienia pisma inicjującego postępowanie zainicjowane pytaniem prawnym sądu Trybunał zauważył, że „uzasadnienie zarzutu nie może mieć charakteru deskryptywnego i ocennego, ale analityczny i argumentacyjny. Uzasadnienie zarzutu powinno polegać na skonfrontowaniu treści zakwestionowanej normy hierarchicznie niższej (tj. przedmiotu kontroli) z normą hierarchicznie wyższą (tj. wzorcem kontroli). Wymogu uzasadnienia zarzutu nie spełnia istnienie wyrażanych w doktrynie czy judykaturze wątpliwości konstytucyjnych pod adresem określonych rozwiązań legislacyjnych. To na podmiocie inicjującym postępowanie przed Trybunałem ciąży obowiązek wykazania niezgodności norm hierarchicznie niższych z normami hierarchicznie wyższymi” (wyrok TK z 8 września 2005 r., sygn. P 17/04, cz. III, pkt 1 uzasadnienia, zob. także postanowienia TK z: 24 marca 2015 r., sygn. akt P 72/14; 13 maja 2015 r., sygn. akt P 58/15; 16 kwietnia 2014 r., sygn. akt P 37/13; 9 września 2013 r., sygn. akt P 21/13; 16 stycznia 2001 r., sygn. akt P 5/00). Niedopełnienie przez sąd pytający obowiązku uzasadnienia zarzutu, z powołaniem argumentów lub dowodów na jego poparcie, stoi na przeszkodzie uznaniu, że spełnione zostały ustawowe warunki dopuszczalności pytania prawnego. Jest to przesłanka umorzenia postępowania w tym zakresie na podstawie art. 59 ust. 1 pkt 2 ustawy o organizacji i trybie postępowania przed TK, ze względu na niedopuszczalność wydania wyroku (zob. np. postanowienia TK z: 18 kwietnia 2018 r., sygn. akt P 15/16; 13 grudnia 2017 r., sygn. akt P 5/17; 23 września 2015 r., sygn. akt P 80/15; 21 września 2015 r., sygn. akt P 109/15).

4. Sąd pytający ograniczył się wyłącznie do sformułowania ogólnego zarzutu niezgodności art. $767^{3 \mathrm{a} a}$ k.p.c. „W zakresie, w jakim na orzeczenie referendarza sądowego nie przysługuje skarga” z art. 78 Konstytucji. W uzasadnieniu postanowienia z 3 października 2017 r. sąd pytający zauważył wyłącznie w sposób ogólny, że art. $767^{3 a}$ k.p.c. pozostaje sprzeczny $z$ art. 78 Konstytucji ze względu na to, że ostateczna weryfikacja decyzji referendarza zgodnie z tym przepisem oraz art. 45 ust. 1 Konstytucji powinna należeć do sądu. Sąd pytający wskazał jeszcze, że istotą zarzutu niezgodności art. $767^{3 a}$ k.p.c. „w zakresie, w jakim na orzeczenie referendarza sądowego nie przysługuje skarga” z art. 78 Konstytucji nie jest uchybienie zasadzie dwuinstancyjności postępowania, ale pozostawienie rozstrzygnięcia 
referendarza bez kontroli sądowej i pozostawienie strony bez środka zaskarżenia wobec tego rozstrzygnięcia.

Tak sformułowane uzasadnienie zarzutu nie spełnia wskazanych wyżej wymogów stawianych uzasadnieniu zarzutów sprzeczności kwestionowanego przepisu z art. 78 Konstytucji. Przepisy art. 45 ust. 1 oraz art. 78 Konstytucji stanowią dwa odrębne wzorce konstytucyjne. Każdy z tych przepisów konstytuuje odmienne normy, przyznające obywatelom prawa podmiotowe o różnej treści. Przepis art. 45 ust. 1 Konstytucji przyznaje prawo do rozpatrzenia sprawy przez niezawisły sąd, z art. 78 Konstytucji wynika natomiast prawo do poddania rozstrzygnięcia dotyczącego obywatela weryfikacji przez kompetentny organ. Postanowienie art. 78 Konstytucji dotyczy zarówno postępowań o charakterze ściśle sądowym, jak i postępowań o charakterze mieszanym, w których rozstrzygnięcie organu niesądowego weryfikuje sąd, ale także postępowań o charakterze niesądowym, w których rozstrzygnięcie organu niesądowego jest weryfikowane przez inny organ nie mający statusu sądu (zob. L. Garlicki, K. Wojtyczek [w:] Konstytucja Rzeczypospolitej Polskiej. Komentarz, t. II, red. L. Garlicki, M. Zubik, Warszawa 2016, s. 878). Można w związku z tym wskazać klarowne różnice w konstrukcji praw podmiotowych wynikających z przepisów Konstytucji powołanych przez sąd pytający. Prawo wynikające z art. 45 Konstytucji odnosi się do sądu jako podmiotu kompetentnego do rozpatrzenia „sprawy”, prawo wynikające $\mathrm{z}$ art. 78 Konstytucji odnosi się natomiast do aspektów proceduralnych, gwarantując możliwość weryfikacji rozstrzygnięcia w „sprawie”, nie przesądzając natomiast, czy taka weryfikacja ma zostać dokonana przez sąd czy przez organ niesądowy. Różny jest także zakres przedmiotowy norm wynikających z art. 45 ust. 1 oraz z art. 78 Konstytucji. Pojęcie „sprawy” wyznaczające zakres prawa do sądu jest inne od pojęć „orzeczenia” i „decyzji” wskazanych w art. 78 Konstytucji. Sąd pytający nie odniósł się do tych różnic. Nie wyjaśnił także, w jaki sposób rozumie treść normy wynikającej z art. 78 Konstytucji. Sąd pytający nie odniósł się też do zróżnicowanej struktury postępowań, w których zapadają orzeczenia referendarzy sądowych. Tylko w niektórych przypadkach zapadają one jako pierwsze rozstrzygnięcia dotyczące określonych elementów postępowania egzekucyjnego [np. rozstrzygnięcie wniosku o obniżenie opłat na podstawie - art. 49 ust. 10 ustawy z 29 sierpnia 1997 r. o komornikach sądowych i egzekucji (t.j. Dz.U. 2017, poz. 1277, ze zm.), lub umorzenie utraconej książeczki oszczędnościowej - art. $893^{2} \$ 1$ k.p.c.]. W innych mają one charakter rozstrzygnięć nadzorczych, których istotą jest weryfikacja poprawności decyzji innego organu egzekucyjnego (komornika) co do sposobu prowadzenia postępowania egzekucyjnego, w tym także praw i obowiązków jego uczestników (np. rozstrzygnięcie skargi na czynność komornika na podstawie art. 767 k.p.c.). Z kontekstu, w jakim sąd pytający odwołał się do art. 78 Konstytucji, wynika, że wszystkie rozstrzygnięcia referendarza traktuje jako rozstrzygnięcia wydane w pierwszej instancji w rozumieniu art. 78 Konstytucji. Sąd pytający nie uzasadnił jednak w jakikolwiek 
sposób takiej kwalifikacji. Sąd pytający nie odniósł się także do dopuszczalnego zakresu ustanawiania $\mathrm{w}$ ustawie wyjątków ograniczających zakres prawa podmiotowego wynikającego z art. 78 Konstytucji.

Wobec powyższego nie można przyjąć, że sąd pytający spełnił wymóg uzasadnienia zarzutu sprzeczności art. $767^{3 a}$ k.p.c. $z$ art. 78 Konstytucji wraz z powołaniem argumentów lub dowodów na poparcie sformułowanego zarzutu. Trybunał kontroluje na każdym etapie postępowania, czy nie zachodzi któraś z ujemnych przesłanek wydania wyroku, skutkujących obligatoryjnym umorzeniem postępowania (zob. np. postanowienia TK z: 18 marca 2009 r., sygn. akt P 13/08; 15 października 2009 r., sygn. akt P 120/08; 6 lipca 2010 r., sygn. akt P 34/09; 29 lutego 2012 r., sygn. akt P 3/10; 26 listopada 2015 r., sygn. akt P 32/13). Wobec niespełnienia wymogów pytania prawnego $\mathrm{z}$ art. 52 ust. 2 pkt 4 ustawy o organizacji i trybie postępowania przed TK, wydanie wyroku w zakresie badania zgodności art. $767^{3 \mathrm{a}} \mathrm{zdanie}$ pierwsze k.p.c. „w zakresie, w jakim na orzeczenie referendarza sądowego nie przysługuje skarga" $z$ art. 78 Konstytucji jest niedopuszczalne, a postępowanie $\mathrm{w}$ tym zakresie powinno zostać umorzone na podstawie art. 59 ust. 1 pkt 2 ustawy o organizacji i trybie postępowania przed TK.

5. W konsekwencji, zdaniem Sejmu, art. $767^{\text {3a }}$ zdanie pierwsze k.p.c. może być przedmiotem kontroli Trybunału Konstytucyjnego jedynie w zakresie, w jakim nie przewiduje skargi na orzeczenie referendarza w przedmiocie skargi na czynności komornika sądowego i wyłącznie w aspekcie jego zgodności z art. 45 ust. 1 Konstytucji.

\section{Zarzut naruszenia art. 45 ust. 1 Konstytucji}

\section{- 1. Stan prawny}

1. Zgodnie $z$ art. $2 \$ 2$ zdanie pierwsze ustawy z dnia 27 lipca $2001 \mathrm{r}$. - Prawo o ustroju sądów powszechnych (t.j. Dz.U. 2018, poz. 23, ze zm.; dalej: p.u.s.p.) referendarze sądowi wykonują w sądach zadania z zakresu ochrony prawnej, inne niż wymiar sprawiedliwości. Zgodnie z art. $2 \$ 2$ a p.u.s.p. czynności, których wykonywanie powierzone zostało referendarzom sądowym, mogą wykonywać również asesorzy sądowi, a także sędziowie, jeżeli wykonywanie tych zadań przez referendarzy sądowych lub asesorów sądowych nie jest możliwe. Wynika stąd, że sprawy tego samego rodzaju mogą być rozpatrywane przez referendarza sądowego, asesora sądowego lub sędziego, w zależności od możliwości kadrowych i organizacyjnych w danym sądzie (A. Górski [w:] Prawo o ustroju sądów powszechnych. Komentarz, red. A. Górski, 2013, LEX, komentarz do art. 2, teza 3).

2. Artykuł $759 \$ 1^{1}$ k.p.c. upoważnia referendarzy do wykonywania w postępowaniu egzekucyjnym wszystkich czynności zastrzeżonych dla sądu, z wyłączeniem sześciu wyjątków wskazanych w tym przepisie. Na jego podstawie referendarze są kompetentni m.in. do rozpoznawania skarg na czynności komornika sądowego. Skarga na czynności komornika jest szczególnym środkiem 
zaskarżenia w postępowaniu egzekucyjnym (zob. np. A. Cudak [w:] Kodeks postępowania cywilnego. Komentarz, t. III, red. A. Marciniak, K. Piasecki, Warszawa 2015, komentarz do art. 767, nb. 2; Z. Świeboda, Komentarz do kodeksu postępowania cywilnego. Część druga. Postępowanie zabezpieczajace i egzekucyjne, Warszawa 2004, komentarz do art. 767, teza 1; O. Marcewicz [w: ]Kodeks postępowania cywilnego. Komentarz aktualizowany, t. II, art. 730-1217, red. A. Jakubecki, 2013, LEX, komentarz do art. 767, teza 2). Skargę na czynności komornika można wnieść na wszelkie czynności egzekucyjne tego organu, a także na zaniechanie dokonania czynności (art. $767 \$ 1$ zdanie pierwsze i drugie k.p.c.). Podmiotem legitymowanym do wniesienia skargi jest strona postępowania egzekucyjnego lub inna osoba, której prawa zostały przez czynności lub zaniechanie komornika naruszone bądź zagrożone (art. $767 \S 2$ k.p.c.). Skarga może zatem służyć zarówno wierzycielowi dążącemu do wykonania orzeczenia sądu wydanego w postępowaniu rozpoznawczym, dłużnikowi przeciwdziałającemu nadmiernej ingerencji organów egzekucyjnych, jak i osobom trzecim nieuczestniczącym wcześniej w postępowaniu rozpoznawczym w razie naruszenia ich praw przez komornika sądowego. Celem skargi na czynności komornika jest wyeliminowanie czynności lub zaniechań komornika, które naruszają przepisy proceduralne. Ani dopuszczalność wniesienia skargi, ani sposób jej rozpoznania nie zależą od wykazania, że proceduralne wadliwości działania lub zaniechania komornika mają lub mogą mieć wpływ na rezultat postępowania egzekucyjnego. Podstawą skargi na czynności komornika nie są naruszenia prawa materialnego. Zakres zastosowania skargi na czynności komornika nie pokrywa się w związku $\mathrm{z}$ tym $\mathrm{z}$ innymi środkami ochrony praw w postępowaniu egzekucyjnym, takimi jak np. powództwa przeciwegzekucyjne (art. 840-842 k.p.c.), których podstawą jest naruszenie prawa materialnego (zob. A. Cudak [w:] Kodeks postępowania cywilnego, op. cit., oraz wyrok SN z 5 października 2016 r., sygn. akt III CZP 41/16).

3. Środkiem zaskarżenia wobec orzeczeń referendarza sądowego jest skarga rozpoznawana przez sąd, w którym wydano orzeczenie (art. $398^{22} \$ 1$ k.p.c.). $\mathrm{W}$ razie wniesienia skargi na orzeczenie referendarza $\mathrm{w}$ postępowaniu egzekucyjnym sąd rozpoznaje sprawę jako sąd drugiej instancji, na podstawie przepisów o zażaleniu (art. $767^{3 \mathrm{a}}$ zdanie trzecie k.p.c.). W postępowaniu egzekucyjnym skarga na orzeczenie referendarza ma charakter niesuspensywny; jej wniesienie nie powoduje utraty mocy przez zaskarżone orzeczenie (art. $767^{3 \mathrm{a}}$ zdanie drugie k.p.c.). Możliwość zaskarżenia rozstrzygnięcia referendarza w postępowaniu egzekucyjnym została jednak ograniczona. Zgodnie $\mathrm{z}$ art. $767^{3 \mathrm{a}} \mathrm{zdanie}$ pierwsze k.p.c. skarga przysługuje jedynie w przypadkach, w których na postanowienie sądu przysługuje zażalenie. Zgodnie z art. $767^{4}$ k.p.c. w postępowaniu egzekucyjnym zażalenie na postanowienie sądu przysługuje w wypadkach wskazanych w ustawie, przy czym w odniesieniu do postanowienia w przedmiocie skargi na czynności komornika zażalenie takie nie zostało przewidziane. W konsekwencji 
postanowienie referendarza, który rozpoznał skargę na czynności komornika, nie może być zaskarżone w trybie art. $398^{22}$ k.p.c.

4. Błędy proceduralne komornika sądowego wskazane w rozpoznanej przez referendarza skardze na czynności komornika, a także proceduralne i merytoryczne błędy popełnione przez referendarza przy rozpoznawaniu tej skargi mogą być jednak w pewnym zakresie przedmiotem kontroli sądowej na podstawie art. 380 k.p.c. Zgodnie z tym przepisem sąd drugiej instancji, na wniosek strony, rozpoznaje również te postanowienia sądu pierwszej instancji, które nie podlegały zaskarżeniu $\mathrm{w}$ drodze zażalenia, a miały wpływ na rozstrzygnięcie sprawy. Jest to przepis dotyczący wprost rozpoznawania apelacji, jednak znajduje on także zastosowanie w postępowaniu zażaleniowym na podstawie art. $397 \$ 2$ k.p.c. (zob. postanowienie SN z 17 maja 2002 r., sygn. akt I CZ 31/02; M. Michalska-Marciniak [w:] Kodeks postępowania cywilnego. Komentarz, t. II, red. A. Marciniak, K. Piasecki, Warszawa 2016, komentarz do art. 397, nb. 2; A. Góra-Błaszczykowska, Środki zaskarżenia w postępowaniu cywilnym. Komentarz do art. 367-424(12) k.p.c., Warszawa 2014, s. 208-209, pkt 7; M. Manowska [w:] Kodeks postępowania cywilnego. Komentarz, t. I, red. M. Manowska, Warszawa 2015, komentarz do art. 397, teza 7). Na podstawie art. $362^{1}$ k.p.c. dyspozycja art. 380 k.p.c. znajduje zastosowanie także do postanowień referendarza sądowego. Przepisy art. $362^{1}$, art. 380 oraz art. $397 \$ 2$ k.p.c. znajdują zaś zastosowanie do postępowania egzekucyjnego na podstawie art. $13 \$ 2$ k.p.c. Postanowienie referendarza w przedmiocie rozpoznania skargi na czynności komornika może być zweryfikowane przez sąd rozpoznający zażalenia na postanowienie w tym zakresie, $\mathrm{w}$ jakim rozstrzygnięcie skargi na czynności komornika miało wpływ na wydanie postanowienia będącego przedmiotem zażalenia. Dotyczy to zarówno postanowień wydawanych przez sąd i postanowień wydawanych przez referendarza sądowego weryfikowanych merytorycznie zgodnie $\mathrm{z}$ art. $767^{3 \mathrm{a}} \mathrm{zda}-$ nie trzecie k.p.c. na skutek wniesienia skarg na postanowienie referendarza. Tak więc m.in. wadliwe uchylenie przez referendarza zajęcia ruchomości mogłoby być przedmiotem kontroli $\mathrm{w}$ ramach zażalenia na postanowienie o umorzeniu postępowania egzekucyjnego na podstawie art. $824 \$ 1$ pkt 3 k.p.c.

W orzecznictwie sądów powszechnych kontrowersyjne pozostają niektóre proceduralne aspekty zastosowania art. 380 k.p.c. Chodzi tu przede wszystkim o kwestię dopuszczalności orzekania w sentencji postanowienia wydanego przez sąd rozpatrujący zażalenie $\mathrm{w}$ granicach wynikających $\mathrm{z}$ art. 380 k.p.c. o uchyleniu wadliwego niezaskarżalnego postanowienia. Najdalej idące stanowisko SN zajął w postanowieniu z 17 maja 2002 r. (sygn. akt I CZ 31/02), w którym przyjął, że sąd, który na podstawie art. 380 k.p.c. stwierdzi wadliwość niezaskarżalnego postanowienia wpadkowego, uchyla $\mathrm{w}$ sentencji orzeczenia to postanowienie. W innych orzeczeniach (zob. np. postanowienia SN z: 21 listopada 2001 r., sygn. akt I CZ 165/01; 12 marca 2003 r., sygn. akt III CZ 16/03; 28 kwietnia 2004 r., sygn. akt III CZ 22/04; 16 listopada 2004 r., sygn. akt III CZP 62/04) SN przy- 
jął, że orzeczenie o uchyleniu niezaskarżalnego postanowienia jest w takim wypadku niedopuszczalne. Na gruncie tego drugiego stanowiska SN uznał jednak, że uchylenie postanowienia, którego wadliwość wynika z wadliwości wydanego wcześniej niezaskarżalnego postanowienia wpadkowego badanego w trybie art. 380 k.p.c. powoduje jednocześnie upadek tego postanowienia wpadkowego bez konieczności odrębnego orzekania o tej okoliczności (postanowienie SN z 12 marca 2003 r., sygn. akt III CZ 16/03). Bez względu na sposób rozstrzygnięcia wskazanej wyżej kontrowersji nie budzi zatem wątpliwości, że zastosowanie art. 380 k.p.c. rodzi dwojakie konsekwencje proceduralne. Po pierwsze, przepis ten pozwala na usunięcie skutków, jakie wadliwość wydanych wcześniej niezaskarżalnych postanowień wywołuje w stosunku do późniejszych, zaskarżalnych orzeczeń. Po drugie, jego zastosowanie prowadzi do upadku mocy wiążącej niezaskarżalnego postanowienia. W konsekwencji można zatem przyjąć, że art. 380 k.p.c. w związku z art. $13 \$ 2$ k.p.c. oraz art. $362^{1}$ i art. $397 \$ 2$ k.p.c. pozwalają na kontrolę sądową niezaskarżalnych postanowień referendarza wydanych w postępowaniu egzekucyjnym w zakresie, w jakim wadliwość tych postanowień wpłynęła na treść późniejszych, zaskarżalnych orzeczeń.

\section{- 2. Wzorzec kontroli}

1. Zgodnie z art. 45 ust. 1 Konstytucji: „Każdy ma prawo do sprawiedliwego i jawnego rozpatrzenia sprawy bez nieuzasadnionej zwłoki przez właściwy, niezależny, bezstronny i niezawisły sąd".

Powołany przepis Konstytucji formułuje przysługujące każdemu prawo podmiotowe do rozpatrzenia jego „sprawy” przez sąd. Elementami tego prawa jest prawo dostępu do sądu, prawo do właściwej procedury przed sądem (tzw. sprawiedliwość proceduralna), prawo uzyskania wyroku sądowego oraz zapewnienie możliwości wykonania prawomocnego orzeczenia, jeżeli charakter tego rozstrzygnięcia powoduje, że nadaje się ono do wykonania (zob. wyroki TK z: 4 lutego 2002 r., sygn. akt K 28/02; 19 lutego 2003 r., sygn. akt P 11/02; 27 maja 2008 r., sygn. akt P 59/07; 4 listopada 2010 r., sygn. akt K 19/06, a także P. Sarnecki [w:] Konstytucja Rzeczpospolitej Polskiej, Komentarz, t. II, red. L. Garlicki, M. Zubik, Warszawa 2016, s. 238; J.P. Tarno [w:] System prawa administracyjnego, t. 10, Sadowa kontrola administracji publicznej, red. R. Hauser, Z. Niewiadomski, A. Wróbel, Warszawa 2016, s. 218; P. Grzegorczyk, K. Weitz [w:] Konstytucja RP, t. I, Komentarz. Art. 1-86, red. M. Safjan, L. Bosek, Warszawa 2016, komentarz do art. 45, nb. 26). W ujęciu orzecznictwa TK prawo do sądu to autonomiczne prawo podmiotowe, mające samoistny byt i podlegające ochronie niezależnie od naruszenia innych praw podmiotowych (zob. m.in. postanowienie TK z 14 kwietnia 2004 r., sygn. akt SK 32/01). Zakres tego prawa wyznaczają w pierwszej kolejności pojęcie „sprawy”, będącej przedmiotem rozpatrzenia, oraz pojęcie „sądu”.

2. Trybunał Konstytucyjny w swoich orzeczeniach wskazał, że pojęcie „sprawy" w rozumieniu art. 45 ust. 1 Konstytucji jest pojęciem autonomicznym, a z za- 
sady demokratycznego państwa prawnego płynie dyrektywa interpretacyjna zakazująca zawężającej wykładni prawa do sądu (zob. orzeczenia TK z: 16 marca 1999 r., sygn. akt SK 19/98; 2 września 2008 r., sygn. akt K 35/06; 8 listopada 2001 r., sygn. akt $\mathrm{P}$ 6/01; 8 października 2002 r., sygn. akt K 36/00; 18 października 2011 r., sygn. akt SK 39/09; 29 czerwca 2010 r., sygn. akt P 28/09). Pojęcie sprawy obejmuje nie tylko rozstrzygnięcie sporów ze stosunków prawnych, ale także przyznawanie szczególnej ochrony sądu w sytuacjach, w których nie toczy się spór między stronami stosunku prawnego (wyrok TK z 6 listopada 2012 r., sygn. akt K 21/11; P. Sarnecki [w:] Konstytucja Rzeczpospolitej Polskiej, op. cit., s. 235). Prawem do sądu objęte są sytuacje, w których rozstrzyga się o prawach podmiotu w relacji do podmiotów równorzędnych lub do władzy publicznej, przy czym ze względu na charakter danych stosunków wykluczone jest arbitralne rozstrzyganie o sytuacji prawnej podmiotu przez drugą stronę tego stosunku (wyrok TK z 10 maja 2000 r., sygn. akt K 21/99). Przez pojęcie „sprawy” rozumiane są także wszystkie przypadki rozstrzygania o prawach konkretnej osoby (zob. m.in. wyroki TK z: 25 lutego 2002 r., sygn. akt SK 29/01; 19 lutego 2003 r., sygn. akt P 11/02; 5 lipca 2005 r., sygn. akt SK 26/04; 22 września 2009 r., sygn. akt SK 3/08; 13 marca 2012 r., sygn. akt P 39/10; 22 stycznia 2013 r., sygn. akt SK 18/11). W wyroku z 31 marca 2009 r. (sygn. akt SK 19/08) Trybunał wskazał jednak, że charakteru "sprawy” w rozumieniu art. 45 ust. 1 Konstytucji nie mają rozstrzygnięcia, które nie dotyczą bezpośrednio uprawnień o charakterze materialnoprawnym, chociażby rzutowały na możliwość korzystania z jednej z konstytucyjnych gwarancji tych praw, a mianowicie prawa do sądu. Trybunał wskazał też, że jeżeli określone rozstrzygnięcie ma charakter „służebny” wobec postępowania merytorycznego, mając na celu umożliwienie jego prowadzenia i uzyskania rozstrzygnięcia sprawy głównej, to rozstrzygnięcie takie nie jest samo w sobie sprawą, do której stosuje się gwarancje $\mathrm{z}$ art. 45 ust. 1, art. 78 i art. 176 Konstytucji, ale jest jedynie jedną z czynności podejmowanych $w$ ramach rozpoznawania takiej sprawy. Stanowisko Trybunału wyrażone w przywołanym wyroku z 31 marca 2009 r. jest elementem całej linii orzeczniczej, konsekwentnie odmawiającej przymiotu sprawy rozstrzygnięciom o charakterze wyłącznie służebnym lub akcesoryjnym wobec głównego przedmiotu postępowania (zob. np. postanowienia TK z: 11 kwietnia 2011 r., sygn. akt Ts 21/09; 21 kwietnia 2016 r., sygn. akt Ts 109/05; 24 marca 2017 r., sygn. akt Ts 186/16, oraz wyrok TK z 22 października 2015 r., sygn. akt SK 28/14). Jednocześnie Trybunał dostrzegł, że odmowa zakwalifikowania określonego incydentalnego rozstrzygnięcia jako „sprawy” w rozumieniu art. 45 ust. 1 Konstytucji „nie wyklucza zupełnie uznania, że istnieje jednak konieczność przyznania $w$ takich przypadkach ochrony sądowej. Obowiązek taki może wynikać z ogólnego wymogu ukształtowania procedury sądowej zgodnie z zasadami sprawiedliwości proceduralnej" (wyrok TK z 31 marca 2009 r., sygn. akt SK 19/08).

3. Sądem w rozumieniu art. 45 ust. 1 Konstytucji są jedynie sądy i trybunały wskazane w rozdziale VIII Konstytucji (P. Sarnecki [w:] Konstytucja Rzeczpospo- 
litej Polskiej, op. cit., s. 238; W. Santera, Sąd właściwy w rozumieniu Konstytucji RP, „Przegląd Sądowy” 2011, nr 9, s. 9; B. Banaszak, Konstytucja Rzeczpospolitej Polskiej. Komentarz, Warszawa 2012, komentarz do art. 45, nb. 7; P. Grzegorczyk, K. Weitz [w:] Konstytucja RP, op. cit., komentarz do art. 45, nb. 66). Sądem w znaczeniu art. 45 ust. 1 Konstytucji nie jest natomiast referendarz sądowy (zob. np. wyroki TK z: 1 grudnia 2008 r., sygn. akt P 54/07, oraz 12 maja 2011 r., sygn. akt P 38/08). W sprawach rozstrzyganych przez referendarzy sądowych prawo do sądu realizowane jest przez objęcie rozstrzygnięć referendarzy nadzorem judykacyjnym właściwego sądu. Niezbędne jest zatem ustanowienie regulacji, które zagwarantują prawo do sądowej kontroli rozstrzygnięć wydawanych w sprawach przez referendarzy jako niesądowe organy administracji publicznej (wyroki TK z: 14 czerwca 2006 r., sygn. akt K 53/05; 12 maja 2011 r., sygn. akt P 38/08, a także B. Banaszak, Konstytucja, op. cit., komentarz do art. 45, nb. 9). Kontrola taka może zostać zapewniona w ten sposób, że jednostce, której prawa zostały naruszone przez rozstrzygnięcie organu niesądowego, zostanie przyznane prawo zaskarżenia tego rozstrzygnięcia w odrębnym postępowaniu sądowym, którego przedmiotem jest wyłącznie kwestionowane rozstrzygnięcie. Artykuł 45 ust. 1 Konstytucji nie wymaga jednak zastosowania tego właśnie trybu sądowej kontroli rozstrzygnięć referendarza. Dopuszczalne jest także zapewnienie prawa do sądu w ten sposób, że rozstrzygnięcie organu niesądowego nie jest przedmiotem odrębnego postępowania, ale weryfikowane jest w ramach weryfikacji innego rozstrzygnięcia (np. na analogicznych zasadach jak art. 380 k.p.c. pozwala na kontrole postanowień, od których nie przysługuje zażalenie).

4. Podmiotowe prawo do rozstrzygnięcia sprawy przez sąd nie ma charakteru absolutnego. Dopuszczalne jest ograniczenie tego prawa pod warunkiem realizacji przesłanek wskazanych w art. 31 ust. 3 Konstytucji. Ograniczenia prawa do sądu, ustanawiane w drodze ustawy, muszą uwzględniać kategoryczny zakaz zamykania drogi do sądu wyrażony w art. 77 ust. 2 ustawy zasadniczej w zakresie dochodzenia konstytucyjnych wolności i praw. W literaturze wskazuje się, że kryteriów wynikających z art. 31 ust. 3 Konstytucji nie może spełniać wyłączenie możliwości korzystania z prawa do sądu w określonym sektorze sporów (P. Sarnecki [w:] Konstytucja Rzeczpospolitej Polskiej, op. cit., s. 236).

\section{- 3. Ocena zgodności}

1. Zdaniem Sejmu postępowanie ze skargi na czynności komornika nie jest samodzielną „sprawą” w rozumieniu art. 45 ust. 1 Konstytucji. Sprawą w tym kontekście jest całe postępowanie egzekucyjne, mające na celu realizację materialnych praw wierzyciela, zmierzające do wykonania orzeczenia zapadłego w postępowaniu rozpoznawczym. Bardziej precyzyjnie sprawę egzekucyjną można zdefiniować jako sprawę wynikająca ze stosunków z zakresu prawa cywilnego, rodzinnego i opiekuńczego oraz prawa pracy (sprawa egzekucyjna w znaczeniu materialnym), a także sprawę, która nie wynika z zakresu wspomnianych stosun- 
ków, ale na podstawie przepisów szczególnych podlega załatwieniu według przepisów Kodeksu postępowania cywilnego. Załatwienie sprawy egzekucyjnej polega na przymusowej (tj. za pomocą środków przymusu określonych w przepisach części trzeciej Kodeksu postępowania cywilnego) realizacji praw i obowiązków stron postępowania egzekucyjnego ściśle określonych w tytułach egzekucyjnych, jeżeli ich wykonanie zostało powierzone sądom lub komornikom sądowym. Tak rozumiana sprawa egzekucyjna niewątpliwie mieści się w pojęciu „sprawy” zawartym w art. 45 ust. 1 Konstytucji. Postępowanie zainicjowane skargą na czynności komornika spełnia natomiast wskazane w wyroku TK z 31 marca 2009 r. (sygn. akt SK 19/08) przesłanki postępowania wpadkowego odgrywającego wyłącznie służebną rolę wobec sprawy głównej. Postanowienie w przedmiocie skargi na czynności komornika nie rozstrzyga o uprawnieniach stron (uczestników) postępowania egzekucyjnego z zakresu prawa materialnego, ale odnosi się wyłącznie do uprawnień wynikających z prawa procesowego. Nie kończy ono postępowania egzekucyjnego, jak również nie zamyka jego samodzielnej części, lecz dotyczy kwestii incydentalnej, powstałej w toku postępowania. Złożenie skargi na czynności komornika służy jedynie skorygowaniu nieprawidłowości o charakterze proceduralnym, które dotknęły właściwą sprawę egzekucyjną. Nie następuje tu merytoryczne rozstrzygnięcie sporu wynikłego ze stosunku prawnego prawa materialnego.

Również orzecznictwo SN akcentuje różnicę między skargą na czynności komornika a postępowaniami służącymi ochronie praw podmiotowych wynikających z prawa materialnego (m.in. powództwami przeciwegzekucyjnymi). Te dwie grupy środków prawnych funkcjonują w postępowaniu egzekucyjnym w sposób autonomiczny; osoba uprawniona może z nich swobodnie korzystać, a ich wybór zależy od rodzaju zarzutów, które są podstawą wniesienia środka zaskarżenia (zob. m.in. wyroki SN z: 27 marca 2003 r., sygn. akt V CKN 18/01; 5 października 2016 r., sygn. akt III CZP 41/16, oraz 11 maja 2017 r., sygn. akt II CSK 590/16). Ochrona prawidłowości rozstrzygnięć proceduralnych jest aksjologicznie i funkcjonalnie podporząadkowana ochronie uprawnień o charakterze materialnoprawnym. Jest to konsekwencja miejsca, jakie normom proceduralnym przypisuje się w porządku prawnym. Zarówno na gruncie prawa prywatnego, jak i prawa administracyjnego oraz karnego przyjmuje się, że normy procesowe określają tryb (sposób) dochodzenia praw i urzeczywistniania obowiązków wynikających z norm materialnoprawnych wymagających konkretyzacji. Prawo formalne ma zatem charakter służebny w stosunku do unormowań prawa materialnego (zob. W. Federczyk, M. Klimaszewski, B. Majchrzak, Postępowanie administracyjne, Warszawa 2018, s. 2; J. Skorupka [w:] System prawa karnego procesowego, t. I, cz. 1, red. P. Hofmański, Warszawa 2013, s. 144-145; A. Zieliński, Postępowanie cywilne. Kompendium, Warszawa 2016, s. 3; A. Sikorski [w:] Postępowanie cywilne, red. I. Gil, Warszawa 2017, s. 4; J. Studzińska, P. Cioch, Postępowanie cywilne, Warszawa 2016, s. 2). Uprawnienia o charakterze proceduralnym nie mają 
w związku z tym wartości autonomicznej, ale służą ochronie uprawnień o charakterze materialnoprawnym. Pojęcia sprawy w rozumieniu art. 45 ust. 1 Konstytucji nie można interpretować w oderwaniu od interesów materialnoprawnych, których ochronie ma służyć prawo do rozpatrzenia sprawy przez niezawisły sąd w prawidłowo prowadzonym postępowaniu. Postępowanie w przedmiocie skargi na czynności komornika ogranicza się do rozpoznawania proceduralnej poprawności czynności komornika bez konieczności odniesienia się do wpływu uchybień proceduralnych na materialne uprawnienia strony postępowania lub osób trzecich ani na wynik sprawy egzekucyjnej jako całości. Są to okoliczności, które przemawiają przeciwko uznaniu, że to postępowanie jest odrębną sprawą w rozumieniu art. 45 ust. 1 Konstytucji.

2. Istnieje możliwość, że uchybienia proceduralne komornika sądowego wpłyną na wynik postępowania egzekucyjnego, prowadząc w ten sposób pośrednio do naruszenia materialnoprawnych uprawnień stron. Związek między naruszeniem norm proceduralnych i materialnych nie jest jednak konieczny. Jak podkreślono wyżej, nie jest on badany w postępowaniu, którego przedmiotem jest rozpoznanie skargi na czynności komornika, ponieważ nie jest on przesłanką tego rozstrzygnięcia. Ewentualna ochrona materialnoprawnych interesów stron jest więc możliwą, choć niekonieczną konsekwencją prawidłowego rozpoznania sprawy. Taki pośredni związek między przedmiotem rozstrzygnięcia a ochroną uprawnień materialnoprawnych nie wystarczy, aby postępowaniu wpadkowemu nadać walor odrębnej sprawy. Należy zatem przyjąć, że rozstrzygnięcie w przedmiocie skargi na czynności komornika nie ma charakteru „służebnego” wobec postępowania merytorycznego, mając na celu umożliwienie jego prawidłowego prowadzenia i jako takie nie jest samo w sobie sprawą, do której stosuje się gwarancje $z$ art. 45 ust. 1 Konstytucji.

3. Uznanie, że postępowanie w przedmiocie rozpoznania skargi na czynności komornika nie ma charakteru odrębnej sprawy w rozumieniu art. 45 ust. 1 Konstytucji nie zamyka rozważań dotyczących sprzeczności art. $767^{3 \mathrm{a}}$ zdanie pierwsze k.p.c. „w zakresie, w jakim na orzeczenie referendarza w przedmiocie skargi na czynności komornika sądowego nie przysługuje skarga” z tym wzorcem konstytucyjnym. Brak przyznania ochrony sądowej w stosunku do rozstrzygnięcia wpadkowego, które nie ma charakteru odrębnej sprawy, może prowadzić do naruszania art. 45 ust. 1 Konstytucji, jeżeli takie ukształtowanie procedury pozbawia jednostkę gwarancji procesowych w sprawie głównej do tego stopnia, że naruszone zostaje prawo do sprawiedliwego rozpatrzenia tej sprawy (wyrok TK z 31 marca 2009 r., sygn. akt SK 19/08). Zdaniem Sejmu norma wynikająca $\mathrm{z}$ art. $767^{3 \mathrm{a}} \mathrm{zdanie}$ pierwsze k.p.c., zgodnie z którą na postanowienie referendarza sądowego w przedmiocie rozpoznania skargi na czynności komornika nie przysługuje skarga, nie narusza konstytucyjnego wymogu sprawiedliwości proceduralnej. Wymóg ten w odniesieniu do postępowania egzekucyjnego należy rozumieć w ten sposób, że ustawodawca stworzy warunki sprzyjające szybkiej 
realizacji tytułu egzekucyjnego oraz zapewni możliwość ochrony praw uczestników postępowania, które mogą naruszyć organy egzekucyjne (zob. wyroki TK z: 19 lutego 2008 r., sygn. akt P 49/06; 27 maja 2008 r., sygn. akt P 59/07). W tym kontekście należy wskazać, że wyłączenie możliwości złożenia skargi na rozstrzygnięcie referendarza sądowego w przedmiocie skargi na czynności komornika sądowego nie może przesądzać o niezrealizowaniu postulatu sprawiedliwości proceduralnej oraz zapewnienia drogi sądowej w odniesieniu do postępowania egzekucyjnego jako całości.

Rozpoznanie skargi na czynności komornika jest jednym z wielu elementów postępowania egzekucyjnego. Nadzór sądu nad prawidłowością tego postępowania w najważniejszych obszarach jest zapewniony przez obowiązujące prawo. Po pierwsze, zgodnie $z$ art. $759 \$ 1^{1}$ k.p.c. rozstrzygnięcia dotyczące obszarów postępowania egzekucyjnego, w przypadku których istnieje największe ryzyko naruszenia praw i wolności uczestników postępowania, zostały wyłączone z zakresu kompetencji referendarzy sądowych. Po drugie, w istotnych kwestiach dotyczących przebiegu postępowania egzekucyjnego, które objęte zostały kompetencją referendarzy sądowych, przepisy Kodeksu postępowania cywilnego zapewniają możliwość złożenia skargi na postanowienie referendarza. Dotyczy to ponad dwudziestu przypadków uregulowanych w trzeciej części Kodeksu (zob. zestawienie: A. Cudak [w:] Kodeks postępowania cywilnego, op. cit., komentarz do art. 7674, nb. 2), a także na podstawie art. $394 \$ 1$ k.p.c. w związku z art. $13 \$ 2$ k.p.c. postanowień kończących postępowanie oraz postanowień wskazanych w pkt 1-12 art. $394 \$ 1$ k.p.c. (zob. A. Zieliński, K. Flaga-Gieruszyńska, Kodeks postępowania cywilnego. Komentarz, Warszawa 2015, komentarz do art. $767^{4}$, nb. 2; P. Cieślak [w:] Kodeks postępowania cywilnego. Komentarz, t. II, red. J. Jankowski, Warszawa 2015, komentarz do art. $767^{4}$, nb. 4; A. Cudak [w:] Kodeks postępowania cywilnego, $o p$. cit.). Jest to na tyle szerokie umożliwienie sądowej kontroli przebiegu postępowania egzekucyjnego, że należy przyjąć, iż przypadek wykluczenia dopuszczalności skargi na postanowienie referendarza w przedmiocie rozstrzygnięcia skargi na czynności komornika nie może przesądzać o naruszeniu wymogu sprawiedliwości proceduralnej w odniesieniu do całego postępowania egzekucyjnego. Po trzecie, orzeczenia referendarzy sądowych, wobec których nie przysługuje skarga, poddane są kontroli sądowej w trybie art. 380 k.p.c. w związku z art. 13 \$ 2 k.p.c. oraz art. $362^{1}$ i $397 \$ 2$ k.p.c. Pozwala to na ich weryfikację przez sąd w takim zakresie, w jakim wpływają one na istotne rozstrzygnięcia dotyczące postępowania egzekucyjnego w stosunku, do których ustawa przewiduje środki zaskarżenia. To wyliczenie pokazuje, że zakres kontroli sądowej nad postępowaniem egzekucyjnym jest szeroki. Tak więc należy przyjąć, że sposób ukształtowania tego postępowania spełnia standardy sprawiedliwości proceduralnej. Wprowadzenie możliwości wniesienia skargi na każde wpadkowe rozstrzygnięcie referendarza sądowego w postępowaniu egzekucyjnym nie może być wobec tego uznane za konieczny wymóg sprawiedliwego ukształtowania procedury egzekucyjnej. 
4. Wobec możliwość weryfikacji w trybie art. 380 k.p.c. niezaskarżalnych postanowień i zarządzeń referendarza sądowego wydanych w postępowaniu egzekucyjnym nietrafne są zarzuty, że takie rozstrzygnięcia referendarza nie podlegają jakiejkolwiek kontroli sądowej. Nawet gdyby przyjąć, że rozstrzygnięcie w przedmiocie skargi na czynności komornika jest odrębną sprawą w rozumieniu art. 45 ust. 1 Konstytucji, to w świetle możliwości sądowej kontroli rozstrzygnięcia referendarza w trybie art. 380 k.p.c. należałoby uznać, że prawo do sądu uczestników postępowania nie zostało tutaj wyłączone, a jedynie ograniczone. Ograniczenie to polega na tym, że rozstrzygnięcie referendarza, na które nie przysługuje skarga, może być przedmiotem kontroli sądowej w tym zakresie, w jakim miały one wpływ na zaskarżalne rozstrzygnięcie wydane przez sąd lub referendarza w postępowaniu egzekucyjnym. Jest to ograniczenie istotne, ale spełniające kryteria sformułowanie w art. 31 ust. 3 Konstytucji. Szybkość postępowania jest jedną z wartości wskazanych na gruncie art. 45 ust. 1 Konstytucji. Na etapie postępowania egzekucyjnego „prawo do rozpatrzenia sprawy bez zbędnej zwłoki” oznacza obowiązek ukształtowania norm proceduralnych w sposób sprzyjający sprawnemu podejmowaniu czynności egzekucyjnych oraz szybkości uzyskania wiążących rozstrzygnięć. Z tego punktu widzenia ograniczenia kontroli sądowej nad rozstrzygnięciami niesądowych organów egzekucyjnych dotyczących procesowych aspektów postępowania wyłącznie do przypadków, w których te rozstrzygnięcia mają wpływ na treść innych zaskarżalnych rozstrzygnięć, można uznać za uzasadnione. Nie jest to rozwiązanie specyficzne dla postępowania egzekucyjnego. Analogiczne instytucje obowiązują także w obszarze nadzoru sądów administracyjnych nad działalnością administracji. Z art. $145 \$ 1$ pkt 1 lit. c w związku z art. $3 \$ 2$ pkt 2 ustawy z 30 sierpnia 2002 r. - Prawo o postępowaniu przed sądami administracyjnymi (t.j. Dz.U. 2017, poz. 1369, ze zm.) wynika, że wadliwe rozstrzygnięcia proceduralne podjęte w toku postępowania, na które nie przysługuje zażalenie, podlegają kontroli sądu administracyjnego wyłącznie w tym zakresie, w jakim wadliwość tych rozstrzygnięć proceduralnych ma wpływ na wynik sprawy dotyczącej decyzji lub postanowienia podlegających zaskarżeniu do sądu administracyjnego. W świetle powyższych okoliczności można uznać, że wynikające $\mathrm{z}$ art. $767^{3 \mathrm{a}}$ zdanie pierwsze k.p.c. w związku $\mathrm{z}$ art. 380 , art. $13 \$ 2$, art. $362^{1}$ i $397 \$ 2$ k.p.c. ograniczenie kontroli sądowej rozstrzygnięcia referendarza w przedmiocie skargi na czynności komornika wyłącznie do tych przypadków, w których to rozstrzygnięcie ma wpływ na treść innego zaskarżalnego postanowienia wydanego przez sąd w postępowaniu egzekucyjnym, jest zgodne z art. 45 ust. 1 Konstytucji.

\section{Zarzut naruszenia art. 78 Konstytucji}

\section{- 1. Uwaga wstępna}

Zdaniem Sejmu postępowanie w zakresie zgodności art. $767^{3 \mathrm{a}}$ zdanie pierwsze k.p.c. „W zakresie, w jakim na orzeczenie referendarza w przedmiocie skargi na 
czynności komornika sądowego nie przysługuje skarga" z art. 78 Konstytucji powinno zostać umorzone ze względu na niedopuszczalność wydania wyroku (zob. wyżej pkt II 3-4 stanowiska). Na wypadek, gdyby Trybunał nie podzielił stanowiska Sejmu w tej sprawie, Sejm przedstawia jednak stanowisko dotyczące zgodności art. $767^{\text {3a }}$ zdanie pierwsze k.p.c. „w zakresie, w jakim na orzeczenie referendarza w przedmiocie skargi na czynności komornika sądowego nie przysługuje skarga" z tym konstytucyjnym wzorcem kontroli.

\section{- 2. Wzorzec kontroli}

1. Zgodnie z art. 78 Konstytucji każda ze stron ma prawo do zaskarżenia orzeczeń i decyzji wydanych w pierwszej instancji. Jest to przepis, który kreuje prawo podmiotowe jednostki do zaskarżenia orzeczeń i decyzji wydanych w pierwszej instancji (L. Garlicki, K. Wojtyczek [w:] Konstytucja Rzeczypospolitej, op. cit., s. 876, P. Grzegorczyk, K. Weitz [w:] Konstytucja RP, op. cit., komentarz do art. 78, nb. 7, B. Banaszak, Konstytucja, op. cit., komentarz do art. 78, nb. 3). Gwarancja ustanowiona w art. 78 Konstytucji ma służyć eliminowaniu pomyłek i arbitralności w pierwszej instancji (zob. np. wyroki TK z: 11 maja 2004 r., sygn. akt K 4/03; 20 maja 2008 r., sygn. akt P 18/07; 8 kwietnia 2014 r., sygn. akt SK 22/11; 8 czerwca 2016 r., sygn. akt P 62/14).

Wzorzec wynikający z art. 78 Konstytucji dotyczy zarówno orzeczeń organów sądowych, jak i decyzji oraz orzeczeń organów pozasądowych. Jest to norma o odmiennym zakresie i treści niż prawo do sądu wyrażone w art. 45 ust. 1 Konstytucji oraz zasada dwuinstancyjnego postępowania sądowego wyrażona w art. 176 ust. 1 Konstytucji. Prawo do weryfikacji orzeczenia lub decyzji pierwszej instancji wynikające $\mathrm{z}$ art. 78 Konstytucji może być zrealizowane zarówno $\mathrm{w}$ procedurze sądowej, jak i pozasądowej. Wynika to z charakteru art. 78 Konstytucji, który nie jest kolejnym przepisem ustanawiającym prawo do sądu, ale gwarancją sprawiedliwości proceduralnej w każdym z postępowań (L. Garlicki, K. Wojtyczek [w:] Konstytucja Rzeczypospolitej, op. cit., s. 876; P. Grzegorczyk, K. Weitz [w:] Konstytucja RP, op. cit., komentarz do art. 78, nb. 7; B. Banaszak, Konstytucja, op. cit., komentarz do art. 78, nb. 3; A. Zieliński, Konstytucyjny standard instancyjności postępowania sądowego, „Państwo i Prawo” 2005, z. 11, s. 8).

2. Gwarancja zaskarżalności dotyczy wyłącznie orzeczeń i decyzji rozumianych w sposób autonomiczny jako wszystkie rozstrzygnięcia $\mathrm{w}$ sprawach indywidualnych bez względu na ich nazwę przyjętą na gruncie danej procedury (L. Garlicki, K. Wojtyczek [w:] Konstytucja Rzeczypospolitej, op. cit., s. 880). Gwarancja zaskarżalności dotyczy zarówno rozstrzygnięć merytorycznych, jak i rozstrzygnięć wpadkowych dotyczących ubocznych kwestii postępowania (P. Grzegorczyk, K. Weitz [w:] Konstytucja RP, op. cit., komentarz do art. 78, nb. 14). Zakresem art. 78 Konstytucji nie są objęte czynności materialno-techniczne, które nie mają waloru orzeczenia ani decyzji, ale wyłącznie orzeczenia i decyzje wydane w pierwszej instancji. Artykuł 78 Konstytucji nie daje natomiast prawa 
do zaskarżenia orzeczenia organu lub sądu wydanego w rezultacie wniesienia środka zaskarżenia wobec orzeczenia lub decyzji organu lub sądu pierwszej instancji. Organem lub sądem pierwszej instancji jest ten, przed którym rozpoczyna się postępowanie mające doprowadzić do określonego rozstrzygnięcia (wyrok TK z 1 lutego 2005 r., sygn. akt SK 62/03). Artykuł 78 dopuszcza wprost ustawowe ograniczenie prawa do kontroli instancyjnej. Nie oznacza to jednak całkowitej swobody ustawodawcy w tym zakresie. Dopuszczalność wprowadzenia wyjątku od zaskarżalności pierwszoinstancyjnego orzeczenia lub decyzji zależy od spełnienia przesłanek wskazanych w art. 31 ust. 3 Konstytucji (zob. wyroki TK z: 17 lutego 2004 r., sygn. akt SK 39/02; 14 października 2010 r., sygn. akt K 17/07; 12 kwietnia 2012 r., sygn. akt SK 21/11; 22 października 2013 r., sygn. akt SK 14/13; 26 listopada 2013 r., sygn. akt SK 33/12, a także L. Garlicki, K. Wojtyczek [w:] Konstytucja Rzeczypospolitej, op. cit., s. 890; P. Grzegorczyk, K. Weitz [w:] Konstytucja RP, op. cit., komentarz do art. 78, nb. 77).

\section{- 3. Ocena zgodności}

1. Zdaniem Sejmu art. 78 Konstytucji nie jest właściwym wzorcem kontroli art. $767^{3 \mathrm{a}}$ zdanie pierwsze k.p.c. „W zakresie, w jakim na orzeczenie referendarza w przedmiocie skargi na czynności komornika sądowego nie przysługuje skarga”. Postanowienie referendarza w przedmiocie rozstrzygnięcia skargi na czynności komornika nie może być kwalifikowane jako orzeczenie wydane w pierwszej instancji w rozumieniu art. 78 Konstytucji. Jak już wskazano, skarga na czynności komornika jest kwalifikowana jako szczególny środek zaskarżenia w postępowaniu egzekucyjnym, skierowany w stosunku do czynności i zaniechań innego organu egzekucyjnego, jakim jest komornik. Skarga na czynności komornika ma bardzo szeroki zakres dopuszczalności przedmiotowej. Zasadą jest, że wszystkie czynności komornika mogą być przedmiotem skargi. Dotyczy to zarówno czynności wykonawczych, jak i decyzyjnych (A. Cudak [w:] Kodeks postępowania cywilnego, op. cit.; A. Zieliński, K. Flaga-Gieruszyńska, Kodeks postępowania cywilnego, op. cit., komentarz do art. 767, nb. 1 i 3; P. Cieślak [w:] Kodeks postępowania cywilnego, op. cit., komentarz do art. 767, nb. 1). W zakresie, w jakim skarga odnosi się do prawidłowości czynności decyzyjnych komornika, nie ma wątpliwości, że jest to rozstrzygnięcie drugoinstancyjne, służące weryfikacji decyzji wydanej przez komornika jako organ egzekucyjny pierwszej instancji w rozumieniu art. 78 Konstytucji. Możliwość zaskarżenia czynności decyzyjnej komornika należy w związku z tym uznać za realizację dyspozycji art. 78 Konstytucji. Przepis ten nie gwarantuje natomiast możliwości weryfikacji orzeczeń i decyzji weryfikujących rozstrzygnięcia pierwszoinstancyjne. Artykuł $767^{3 \mathrm{a}}$ zdanie pierwsze k.p.c. w zakresie, w jakim wyklucza on dopuszczalność skargi na orzeczenie referendarza w przedmiocie skargi na decyzyjne czynności komornika sądowego, nie może być zatem rozpatrywany przez pryzmat zgodności z art. 78 Konstytucji. 
2. Skarga na czynności komornika kwalifikowana jest jako szczególny środek zaskarżenia bez względu na to, czy dotyczy czynności komornika o charakterze decyzyjnym, czy wykonawczym (zob. literatura cytowana w pkt III 1.2 stanowiska). Należy jednak zwrócić uwagę, że zaniechania oraz czynności wykonawcze komornika nie są orzeczeniami ani decyzjami w rozumieniu art. 78 Konstytucji (L. Garlicki, K. Wojtyczek [w:] Konstytucja Rzeczypospolitej, op. cit., s. 890). Artykuł 78 Konstytucji nie daje stronom gwarancji zaskarżenia takich czynności. Jednocześnie Konstytucja nie wyklucza wprowadzenia przez ustawodawcę postępowań weryfikujących legalność czynności technicznych oraz terminowość działań organów państwa. Możliwość wykorzystania szczególnego środka zaskarżenia, jakim jest skarga na czynności komornika, jako narzędzia weryfikacji czynności wykonawczych lub bierności organu egzekucyjnego, nie czyni orzeczeń wydanych $\mathrm{w}$ rezultacie wniesienia takiego środka zaskarżenia rozstrzygnięciami pierwszej instancji w rozumieniu art. 78 Konstytucji. Jest to nadal orzeczenie wydane w wyniku wniesienia przez uprawnionego środka, którego celem jest weryfikacja legalności działań lub zaniechań niesądowego organu władzy publicznej. Fakt, że zachowanie niesądowego organu władzy publicznej podlegające zaskarżeniu w trybie skargi na czynności komornika nie ma w danym przypadku przymiotu orzeczenia lub decyzji i nie podlega w związku z tym zakresowi art. 78 Konstytucji, nie uzasadnia przyznania stronie prawa podmiotowego do zaskarżenia rozstrzygnięcia w przedmiocie skargi do kolejnej instancji. Prowadziłoby to do aksjologicznie wadliwego wniosku o konieczności przyznania stronie większych praw w odniesieniu do skarg na czynności komornika dotyczące czynności wykonawczych i zaniechań organu egzekucyjnego niż w odniesieniu do skarg na czynności organu egzekucyjnego o charakterze decyzyjnym.

W rezultacie Sejm stoi na stanowisku, że postanowienie referendarza w przedmiocie rozpoznania skargi na czynności komornika w żadnym przypadku nie powinno być kwalifikowane jako orzeczenie pierwszej instancji w rozumieniu art. 78 Konstytucji, a w związku z tym przepisy wykluczające zaskarżenie takiego postanowienie nie powinny podlegać ocenie zgodności z tym przepisem Konstytucji.

3. Reasumując, na wypadek uznania dopuszczalności kontroli zakwestionowanego przepisu we wskazanym wyżej zakresie, należy stwierdzić, że art. $767^{3 \mathrm{a}}$ zdanie pierwsze k.p.c. $w$ zakresie, $w$ jakim nie przewiduje skargi na orzeczenie referendarza w przedmiocie skargi na czynności komornika sądowego, nie jest niezgodny $z$ art. 78 Konstytucji.

\section{- Bibliografia}

Banaszak B., Konstytucja Rzeczpospolitej Polskiej. Komentarz, Warszawa 2012.

Cieślak P. [w:] Kodeks postępowania cywilnego. Komentarz, t. II, red. J. Jankowski, Warszawa 2015.

Cudak A. [w:] Kodeks postępowania cywilnego. Komentarz, t. III, red. A. Marciniak, K. Piasecki, Warszawa 2015. 
Federczyk W., Klimaszewski M., Majchrzak B., Postępowanie administracyjne, Warszawa 2018.

Garlicki L., Wojtyczek K. [w:] Konstytucja Rzeczpospolitej Polskiej. Komentarz, t. II, red. L. Garlicki, M. Zubik, Warszawa 2016.

Góra-Błaszczykowska A., Środki zaskarżenia w postępowaniu cywilnym. Komentarz do art. 367-424(12) k.p.c., Warszawa 2014.

Górski A. [w:] Prawo o ustroju sq̨dów powszechnych. Komentarz, red. A. Górski, 2013, LEX.

Grzegorczyk P., Weitz K. [w:] Konstytucja RP, t. I, Komentarz. Art. 1-86, red. M. Safjan, L. Bosek, Warszawa 2016.

Manowska M. [w:] Kodeks postępowania cywilnego. Komentarz, t. I, red. M. Manowska, Warszawa 2015.

Marcewicz O. [w:] Kodeks postępowania cywilnego. Komentarz aktualizowany, red. A. Jakubecki, t. II, Art. 730-1217, 2013, LEX.

Markiewicz K. [w:] Kodeks postępowania cywilnego. Komentarz, t. II, red. A. Marciniak, K. Piasecki, Warszawa 2016.

Santera W., Sąd właściwy w rozumieniu Konstytucji RP, „Przegląd Sądowy” 2011, nr 9.

Sarnecki P. [w:] Konstytucja Rzeczpospolitej Polskiej, Komentarz, t. II, red. L. Garlicki, M. Zubik, Warszawa 2016.

Sikorski A. [w:] Postępowanie cywilne, red. I. Gil, Warszawa 2017.

Skorupka J. [w:] System prawa karnego procesowego, t. I, cz. 1, red. P. Hofmański, Warszawa 2013.

Studzińska J., Cioch P., Postępowanie cywilne, Warszawa 2016.

Świeboda Z., Komentarz do kodeksu postępowania cywilnego. Część druga. Postępowanie zabezpieczające i egzekucyjne, Warszawa 2004.

Tarno J.P. [w:] System prawa administracyjnego, t. 10, Sąowa kontrola administracji publicznej, red. R. Hauser, Z. Niewiadomski, A. Wróbel, Warszawa 2016.

Zieliński A., Flaga-Gieruszyńska K., Kodeks postępowania cywilnego. Komentarz, Warszawa 2015.

Zieliński A., Konstytucyjny standard instancyjności postępowania sądowego, „Państwo i Prawo" 2005, z. 11.

Zieliński A., Postępowanie cywilne. Kompendium, Warszawa 2016. 


\section{Ocena zgodności z Konstytucją art. $173 \S 1$ ustawy - Prawo o postępowaniu przed sądami administracyjnymi w zakresie braku możliwości zaskarżenia skargą kasacyjną postanowienia Naczelnego Sądu Administracyjnego odrzucającego skargę o wznowienie postępowania przed Naczelnym Sądem Administracyjnym ${ }^{1}$}

Assessment of conformity to the Constitution of Article 173 para. 1 of the Law on Proceedings Before Administrative Courts as regards the lack of possibility to lodge a cassation appeal against the Supreme Administrative Court's order on rejection of the claim for reopening of the proceedings before the Supreme Administrative Court (SAC) (WAPU-1855/17): The constitutional complaint concerns regulations of the Law on Proceedings Before Administrative Courts. The complainant moves for a statement that Article 173 para 1 of that act does not provide a possibility to lodge a cassation appeal against the Supreme Administrative Court's order on rejection of the claim on for reopening of the proceedings before the SAC. After analysis, it has been assessed that the contested provision conforms to the Constitution of the Republic of Poland. Moreover, there is no real and direct interest of the complaining company which would be protected by the constitutional complaint directed at stating the unconstitutionality of the indicated provision.

Keywords: administrative proceedings, Constitutional Tribunal

Słowa kluczowe: postępowanie administracyjne, Trybunał Konstytucyjny

Doktor hab. nauk prawnych, profesor Katolickiego Uniwersytetu Lubelskiego Jana Pawła II, radca prawny, ekspert ds. legislacji BAS; andrzej.herbet@sejm.gov.pl.

Na podstawie art. 69 ust. $2 \mathrm{w}$ związku z art. 42 pkt 3 ustawy z dnia 30 listopada 2016 r. o organizacji i trybie postępowania przed Trybunałem Konstytucyjnym (Dz. U. poz. 2072), w imieniu Sejmu Rzeczypospolitej Polskiej przedkładam wyjaśnienia w sprawie skargi konstytucyjnej spółki Towarzystwo Zakładów Che-

Projekt stanowiska sporządzony 8 czerwca 2018 r., sygn. akt SK 26/17; BAS-WAPU $1855 / 17$. 
micznych „STREM” Spółka Akcyjna z siedzibą w Konstancinie-Jeziornie z dnia 29 kwietnia 2016 r. (sygn. akt SK 26/17), jednocześnie wnosząc o stwierdzenie, że art. $173 \$ 1$ ustawy z dnia 30 sierpnia 2002 r. - Prawo o postępowaniu przed sądami administracyjnymi (t.j. Dz. U. 2017, poz. 1369, ze zm.) w zakresie, w jakim nie przewiduje możliwości zaskarżenia skargą kasacyjną postanowienia Naczelnego Sądu Administracyjnego odrzucającego skargę o wznowienie postępowania przed Naczelnym Sądem Administracyjnym, jest zgodny z art. 45 ust. $1 \mathrm{w}$ związku z art. 32 ust. 1 oraz art. 78 i art. 176 ust. 1 Konstytucji i nie jest niezgodny $z$ art. 77 ust. 2 Konstytucji.

\section{Uzasadnienie}

\section{Przedmiot kontroli}

1. Przedmiotem kontroli konstytucyjności zainicjowanej skargą konstytucyjną inkorporowanej jeszcze przed II wojną światową spółki pod firmą Towarzystwo Zakładów Chemicznych „STREM” Spółka Akcyjna (dalej: skarżąca albo TZC „STREM” S.A.) jest art. $173 \$ 1$ ustawy z dnia 30 sierpnia 2002 r. - Prawo o postępowaniu przed sądami administracyjnymi (t.j. Dz. U. 2017, poz. 1369, ze zm.; dalej: p.p.s.a.). Aktualnie przepis ten stanowi: „Od wydanego przez wojewódzki sąd administracyjny wyroku lub postanowienia kończącego postępowanie w sprawie, z wyłączeniem przypadków, o których mowa w art. $58 \$ 1$ pkt 2-4, art. $161 \$ 1$ oraz art. $220 \$ 3$, przysługuje skarga kasacyjna do Naczelnego Sądu Administracyjnego".

Przepisy, do których odsyła art. $173 \$ 1$ p.p.s.a. w aktualnym brzmieniu, wymieniają kategorie rozstrzygnięć kończących postępowanie, od których skarga kasacyjna nie przysługuje. Są to: postanowienie o odrzuceniu skargi wniesionej po upływie terminu do jej wniesienia, w razie nieuzupełnienia jej braków formalnych w wyznaczonym terminie albo w sytuacji, w której sprawa objęta skargą pomiędzy tymi samymi stronami jest w toku lub została już prawomocnie osądzona (art. $58 \$ 1$ pkt 2-4 p.p.s.a.), postanowienie o umorzeniu postępowania $\mathrm{w}$ razie skutecznego cofnięcia skargi, śmierci strony (jeżeli przedmiot postępowania odnosi się wyłącznie do praw i obowiązków ściśle związanych z osobą zmarłego, chyba że udział w sprawie zgłasza osoba, której interesu prawnego dotyczy wynik tego postępowania) lub bezprzedmiotowości postępowania $z$ innych przyczyn (art. $161 \$ 1$ p.p.s.a.) oraz postanowienie o odrzuceniu skargi, skargi kasacyjnej, zażalenie lub skargi o wznowienie postępowania, od których pomimo wezwania nie został uiszczony należny wpis (art. $220 \$ 3$ p.p.s.a.).

2. W dacie wydawania ostatecznego rozstrzygnięcia $w$ sprawie skarżącej (tj. 20 stycznia 2016 r.) przepis art. $173 \$ 1$ p.p.s.a. miał brzmienie następujące: „Od wydanego przez wojewódzki sąd administracyjny wyroku lub postanowienia kończącego postępowanie w sprawie przysługuje skarga kasacyjna do Naczelnego 
Sądu Administracyjnego, chyba że przepis szczególny stanowi inaczej”. Treść zakwestionowanego przepisu uległa zmianie, w kierunku wskazanym powyżej, na podstawie art. 1 pkt 48 ustawy z dnia 9 kwietnia 2015 r. o zmianie ustawy - Prawo o postępowaniu przed sądami administracyjnymi (Dz. U. poz. 658; dalej: ustawa zmieniająca z 2015 r.) z dniem 15 sierpnia 2015 r. Skarżąca - nawiązując do art. 2 ustawy zmieniającej z 2015 r. - podkreśla wprawdzie, że żąda kontroli konstytucyjności art. $173 \$ 1$ p.p.s.a. w brzmieniu pierwotnym, obowiązującym przed 15 sierpnia 2015 r. Jednak w związku z tym, że wprowadzenie przywołanego wyżej katalogu przypadków, w których skarga kasacyjna do Naczelnego Sądu Administracyjnego nie przysługuje, nie ma znaczenia dla istoty problemu stawianego przez inicjatorkę postępowania w niniejszej sprawie, czynienie takiego zastrzeżenia wydaje się bezzasadne. Przedmiotem kontroli powinienem być zatem art. 173 $\$ 1$ p.p.s.a. w brzmieniu obowiązującym, w zakresie wskazanym przez skarżącą.

3. Skarżąca żąda kontroli konstytucyjności art. $173 \$ 1$ p.p.s.a. „W zakresie, w jakim przepis ten nie przewiduje możliwości zaskarżenia skargą kasacyjną postanowienia Naczelnego Sądu Administracyjnego odrzucającego skargę o wznowienie postępowania przed Naczelnym Sądem Administracyjnym, orzekającego po raz pierwszy w tym przedmiocie". Innymi słowy, nie kwestionuje ona konstytucyjności normy wyraźnie w tym przepisie wysłowionej, ale brak tego, co - jej zdaniem - ustawodawca powinien w nim unormować, działając zgodnie z przywołanymi uregulowaniami konstytucyjnymi. Tak ujęta istota problemu ma swoje oczywiste konsekwencje na tle analizy formalnoprawnej (zob. niżej, pkt III.5 stanowiska).

\section{Stan faktyczny}

1. Stan faktyczny, na tle którego została wniesiona niniejsza skarga konstytucyjna, jest relatywnie skomplikowany i wielowątkowy. U jej podstaw leży skarga TZC „STREM” S.A. na decyzję Ministra Gospodarki z 18 grudnia 2002 r. (znak OL-0241/44/00/R/ZS/1436/02/Z), odmawiającą stwierdzenia nieważności orzeczenia nr 22 Ministra Przemysłu i Handlu z dnia 12 lutego 1948 r. o przejęciu przedsiębiorstw na własność Państwa (M. P. Nr 44, poz. 222), wydanego na podstawie art. 3 ust. 6 ustawy z dnia 3 stycznia 1946 r. o przejęciu na własność Państwa podstawowych gałęzi gospodarki narodowej (Dz. U. Nr 3, poz. 17, ze zm.) w części dotyczącej przedsiębiorstwa Towarzystwo Zakładów Chemicznych „STREM”, Warszawa, ul. Mazowiecka 7. W uzasadnieniu decyzji Minister Gospodarki stwierdził, że całość zgromadzonego w sprawie materiału dowodowego nakazała uznać, że w dniu 5 lutego 1946 r. TZC „STREM” S.A. spełniało ustawową przesłankę stanowiącą podstawę do objęcia zakładu procesem upaństwowienia. Po złożeniu przez skarżącą wniosku o ponowne rozpatrzenie sprawy powyższa decyzja Ministra Gospodarki została utrzymana w mocy decyzją Ministra Gospodarki, Pracy i Polityki Społecznej z 3 lipca 2003 r. (znak BOL-0241/44/00/R/ZS/784/03). W następstwie skargi skarżącej Wojewódzki Sąd Administracyjny w Warszawie, 
wyrokiem z 30 września 2004 r. (sygn. akt IV SA 2963/03), uchylił zaskarżoną decyzję, jak i poprzedzającą ją decyzję Ministra Gospodarki z 18 grudnia 2002 r. Uwzględnienie skargi kasacyjnej od wyroku złożonej przez uczestnika postępowania - Tarchomińskie Zakłady Farmaceutyczne „Polfa” S.A. - spowodowało jednak, że orzeczenie to zostało uchylone wyrokiem Naczelnego Sądu Administracyjnego z 23 marca 2007 r. (sygn. akt I OSK 1920/06), a sprawa została przekazana do ponownego rozpoznania Wojewódzkiemu Sądowi Administracyjnemu w Warszawie. Po ponownym rozpoznaniu sprawy, wyrokiem z 29 czerwca 2007 r. (sygn. akt IV SA/Wa 877/07), Wojewódzki Sąd Administracyjny w Warszawie powtórnie uchylił decyzje administracyjne z 3 lipca 2003 r. oraz z 18 grudnia 2002 r. W następstwie kolejnej skargi kasacyjnej uczestnika postępowania Naczelny Sąd Administracyjny - wyrokiem z 17 listopada 2008 r. (sygn. akt I OSK 1664/07) - uchylił zaskarżony wyrok z 29 czerwca 2007 r. oraz oddalił skargę skarżącej na decyzję Ministra Gospodarki z 3 lipca 2003 r. W uzasadnieniu tego orzeczenia NSA wskazał, że nie można podzielić zarzutu wystąpienia rażącego naruszenia prawa wywołanego wszczęciem postępowania nacjonalizacyjnego po dacie wskazanej w rozporządzeniu. W ocenie sądu postępowanie to składało się bowiem w pierwszej kolejności z postępowania przygotowawczego (unormowanego w $\$ 16-23$ rozporządzenia), które wszczynane było w dacie złożenia wniosku. Za takim rozumieniem terminu „wszczęcie postępowania” miała przemawiać także - zdaniem NSA - późniejsza nowelizacja przepisów rozporządzenia, nadająca $\$ 17$ ust. 1 tego aktu brzmienie: „Wszczęcie postępowania następuje z chwilą przedłożenia wniosków określonych w $\$ 19$ ”. Naczelny Sąd Administracyjny negatywnie ocenił też odwołanie się przez sąd administracyjny I instancji do poglądu Sądu Najwyższego wyrażonego w wyroku z 8 marca 2001 r. (sygn. akt III RN 176/00), podkreślając, że orzeczenie to wydane zostało w zupełnie innych okolicznościach faktycznych sprawy. Niezależnie od tego, NSA wskazał, że nawet przyjmując, iż datą pewną wszczęcia postępowania nacjonalizacyjnego była w przypadku skarżącej data ogłoszenia wykazu przedsiębiorstw przechodzących na własność Państwa, to i tak nie można stwierdzić naruszenia terminu określonego w art. 3 ust. 6 ustawy nacjonalizacyjnej. W ocenie sądu „określenie bowiem, że postępowanie nacjonalizacyjne mogło nastąpić przed dniem 31 marca $1947 \mathrm{r}$. oznacza, że nie mogło ono nastąpić po tym dniu, czyli po zakończeniu miesiąca marca tego roku”. W konkluzji Naczelny Sąd Administracyjny stwierdził, że zarzut naruszenia prawa materialnego postawiony w skardze kasacyjnej był uzasadniony i w związku z tym, na podstawie art. 188 w związku z art. 151 p.p.s.a., uchylił zaskarżony wyrok i skargę skarżącej oddalił.

2. W dniu 21 lipca 2015 r. skarżąca złożyła do Naczelnego Sądu Administracyjnego skargę o wznowienie postępowania zakończonego wyrokiem tego sądu z 17 listopada 2008 r. (sygn. akt I OSK 1664/17). Jako podstawę wznowienia wskazano art. 271 pkt 2 p.p.s.a. w związku z zarzucanym brakiem należytej reprezentacji w postępowaniu przed NSA (według twierdzeń skarżącej, nie miała 
ona w tym okresie organu uprawnionego do reprezentacji, tj. prawidłowo powołanego zarządu). Naczelny Sąd Administracyjny postanowieniem z 10 listopada 2015 r. (sygn. akt I OSK 2229/15) odrzucił skargę stwierdziwszy, że wniesiono ją po upływie terminu wynikającego z art. 277 p.p.s.a. Sąd, opierając się na treści wpisów w rejestrze przedsiębiorców KRS, nie podzielił argumentacji skarżącej o braku organów uprawnionych do reprezentacji TZC „STREM” S.A. w niemal siedmioletnim okresie pomiędzy prawomocnym zakończeniem postępowania sądowoadministracyjnego a wniesieniem skargi o wznowienie. Skarżąca wniosła od tego orzeczenia skargę kasacyjną, która została odrzucona przez Naczelny Sąd Administracyjny postanowieniem z 20 stycznia 2016 r. (sygn. akt I OSK 2229/15), z powołaniem się na art. $173 \$ 1$ i art. $180 \mathrm{w}$ związku z art. 178 p.p.s.a.

\section{Analiza formalnoprawna}

1. Zgodnie z art. 79 Konstytucji, każdy, czyje prawo lub wolność konstytucyjna zostały naruszone, może wnieść skargę konstytucyjną w sprawie zgodności z Konstytucją ustawy lub innego aktu normatywnego, na podstawie którego sąd lub organ administracji publicznej orzekł ostatecznie o jego wolnościach lub prawach albo o jego obowiązkach określonych w Konstytucji. Skarga konstytucyjna może zostać złożona po wyczerpaniu drogi prawnej, o ile droga ta jest przewidziana, w ciągu 3 miesięcy od doręczenia skarżącemu prawomocnego wyroku, ostatecznej decyzji lub innego ostatecznego rozstrzygnięcia (art. 77 ust. 1 ustawy z dnia 30 listopada 2016 r. o organizacji i trybie postępowania przed Trybunałem Konstytucyjnym; Dz. U. poz. 2072; dalej: u.o.t.p.TK)

2. Akcentowana w art. 79 ust. 1 Konstytucji zależność między przedmiotem skargi konstytucyjnej a jednostkowym orzeczeniem podjętym wobec skarżącego przesądza o jego legitymacji do wystąpienia $\mathrm{z}$ tym środkiem ochrony praw i wolności, a jednocześnie nadaje skardze konstytucyjnej niezbędny - w świetle założeń wyrażonych przywołanym przepisie - charakter środka inicjowania tzw. konkretnej kontroli prawa przed Trybunałem Konstytucyjnym. Analizując problem podstawy prawnej ostatecznego orzeczenia wydanego wobec skarżącego, należy zwrócić uwagę, że za taką podstawę mogą być uznane tylko te przepisy, które wyrażają normy prawne bezpośrednio określające sytuację prawną skarżącego w chwili wydania ostatecznego orzeczenia. Konieczną przesłanką skargi jest więc wykazanie związku między kwestionowanym unormowaniem a ostatecznym orzeczeniem, z którego wydaniem skarżący wiąże zarzut naruszenia jego praw (zob. przykładowo postanowienia TK z: 19 października 2004 r., sygn. akt SK 13/03; 15 lipca 2002 r., sygn. akt Ts 5/02). Ponadto przepisy wskazane przez inicjatora postępowania, będąc podstawą ostatecznego orzeczenia sądu, powinny jednocześnie stanowić bezpośrednie źródło naruszenia jego konstytucyjnych wolności lub praw (dotyczyć go osobiście). Naruszenie musi mieć charakter osobisty i aktualny (rzeczywisty), a nie potencjalny, czyli możliwy do wyobrażenia w realiach innych niż sytuacja faktyczna i prawna skarżącego (zob. przykładowo 
postanowienia TK z: 17 marca 1998 r., sygn. akt Ts 11/97; 19 października 2004 r., sygn. akt SK 13/03; 9 lipca 2012 r., sygn. akt SK 19/10).

Powyższy związek bywa wyjaśniany w nieco bardziej rozwiniętej formule w ten sposób, iż: „[p]o pierwsze, przepisy kwestionowane za pomocą skargi konstytucyjnej stanowić winny normatywną podstawę ostatecznego orzeczenia wydanego wobec skarżącego w sprawie, w związku z którą wniesiona została skarga konstytucyjna do Trybunału. Po drugie, to w treści tych przepisów tkwić winna bezpośrednia przyczyna zaistniałego naruszenia konstytucyjnych praw lub wolności skarżącego. Po trzecie wreszcie, naruszenie to wywołane być winno wydaniem przez sąd lub organ administracji publicznej orzeczenia opartego na przepisach stanowiących przedmiot skargi konstytucyjnej" (zob. postanowienie TK z 12 stycznia 2012 r., sygn. akt Ts 84/09; zob. także wyrok TK z 18 października 2011 r., sygn. akt SK 39/09). Innymi słowy, dopuszczalność skargi konstytucyjnej zależy - co do zasady - także od tego, czy w wyniku zastosowania aktu normatywnego pogorszyła się sytuacja prawna skarżącego w kontekście jego konstytucyjnych praw i wolności (zob. Z. Czeszejko-Sochacki, Formy naruszenia konstytucyjnych wolności lub praw [w:] Skarga konstytucyjna, red. J. Trzciński, Warszawa 2000, s. 75; L. Jamróz, Skarga konstytucyjna. Wstępne rozpoznanie, Białystok 2011, s. 192). Powinien on to wykazać w ramach spełnienia wymogu „uprawdopodobnienia naruszenia”, które uzasadnia udzielenie ochrony w trybie skargi konstytucyjnej.

Przepisy ustawy o organizacji i trybie postępowania przed Trybunałem Konstytucyjnym nakładają ponadto na podmioty uprawnione do złożenia wniosku (pytania, skargi) do sądu konstytucyjnego konkretne obowiązki, w tym wymóg uzasadnienia postawionego zarzutu, z powołaniem dowodów na jego poparcie (art. 53 ust. 1 pkt 3 u.o.t.p.TK). W swoim wcześniejszym orzecznictwie, które zachowuje pełną aktualność na tle obowiązującego stanu prawnego, Trybunał Konstytucyjny podkreślał, że: „(...) uzasadnienie zarzutów powinno opierać się na przedstawieniu we wniosku takiej argumentacji, która uprawdopodobni ewentualną niekonstytucyjność kwestionowanych przepisów. W szczególności argumentacja taka nie może opierać się jedynie na odczuciach czy wyobrażeniach wnioskodawcy, ale powinna być poparta merytorycznym uzasadnieniem, mogącym uwzględniać m.in. wcześniejsze orzecznictwo TK, praktykę stosowania prawa czy dorobek doktryny" (postanowienie TK z 6 listopada 2007 r., sygn. akt Tw 41/05; zob. także postanowienia TK z: 12 sierpnia 2005 r., sygn. akt Tw 23/05 i 29 sierpnia 2006 r., sygn. akt Tw 14/06). Samo werbalne sformułowanie zarzutu, czy też wskazanie, że kwestionowany przepis jest sprzeczny z innym przepisem aktu hierarchicznie wyższego nie może więc zostać uznane za uzasadnienie zarzutu w sensie procesowym. Zgodnie z art. 67 u.o.t.p.TK Trybunał Konstytucyjny jest bowiem związany treścią oraz granicami rozpatrywanego wniosku, pytania prawnego lub skargi. Tym samym nie może on - wychodząc poza granice określone w piśmie inicjującym postępowanie - wyręczać inicjatora tego postępowania w doborze argumentacji adekwatnej do podnoszonych wątpliwości. Brak odpowiedniego 
uzasadnienia zarzutu niezgodności danego przepisu z przywołanymi wzorcami kontroli stanowi o uchybieniu przez wnioskodawcę ustawowej powinności określonej w art. 53 ust. 1 pkt 3 u.o.t.p.TK (na tle poprzednio obowiązującego art. 32 ust. 1 pkt 4 ustawy z dnia 17 października 1997 r. o Trybunale Konstytucyjnym; Dz. U. Nr 102, poz. 643; dalej: u.TK z 1997 r., por. przykładowo postanowienie TK z 15 października 2009 r., sygn. akt P 120/08) powoduje brak możliwości jego rozpatrzenia przez sąd konstytucyjny i konieczność umorzenia postępowania ze względu na niedopuszczalność wydania wyroku (art. 59 ust. 1 pkt 2 u.o.t.p.TK).

4. W stanie faktycznym, na tle którego została wniesiona niniejsza skarga konstytucyjna, powstają pewne wątpliwości co do spełnienia przesłanki bezpośredniego i realnego (rzeczywistego) naruszenia konstytucyjnych praw skarżącej. W gruncie rzeczy - zwłaszcza z perspektywy możliwości skutecznego wznowienia postępowania sądowoadministracyjnego - sytuacja skarżącej nie uległa bowiem pogorszeniu wskutek zastosowania przez Naczelny Sąd Administracyjny zakwestionowanego przez nią przepisu.

Jak wskazano wcześniej (zob. pkt II.2 stanowiska), skarżąca upatruje podstawy dla wznowienia postępowania sądowoadministracyjnego zakończonego wyrokiem Naczelnego Sądu Administracyjnego z 17 listopada 2008 r. (sygn. akt I OSK 1664/17) w braku właściwej reprezentacji i możliwości działania, ze względu na podnoszony przez nią brak organu uprawnionego do reprezentacji (tj. zarządu) w okresie od 13 września 2006 r. do 2 kwietnia 2015 r. Uzasadnieniem dla tej tezy ma być zmiana $\$ 19$ ust. 3 statutu TZC „STREM” S.A. uchwalona na nadzwyczajnym walnym zgromadzeniu spółki w dniu 7 kwietnia 2004 r., zgodnie z którą: „Tak długo, jak wszystkie akcje w kapitale zakładowym Spółki należą do: Andrzeja Bonarskiego lub Barbary Kabala-Bonarskiej lub - łącznie - do Andrzej Bonarskiego i Barbary Kabala-Bonarskiej albo też co najmniej jednej z wymienionych osób i do Spółki, członków Zarządu, w tym także Prezesa Zarządu, powołuje Andrzej Bonarski lub Barbara Kabala-Bonarska działający łącznie, w zależności od tego, która z wyżej wymienionych osób jest akcjonariuszem Spółki. Powoływanie i odwoływanie członków Zarządu w tym także Prezesa Zarządu odbywa się poprzez złożenie pisemnego oświadczenia na ręce Przewodniczącego Rady Nadzorczej, a gdy nie jest to możliwe na ręce innego członka Rady Nadzorczej”. W rezultacie, powoływanie zarządu skarżącej zostało przekazane do kompetencji wyłącznych akcjonariuszy spółki jako tzw. uprawnienie osobiste, w miejsce dotychczasowego rozwiązania, zgodnie z którym uprawnienie to wykonywało walne zgromadzenie akcjonariuszy. Na tej podstawie skarżąca wywodzi, że mandaty członków zarządu powołanych na trzyletnią kadencję w dniu 27 listopada 2002 r. (również w osobach Andrzeja Bonarskiego i Barbary Kabala-Bonarskiej) wygasły na zwyczajnym walnym zgromadzeniu w dniu 13 września 2006 r., zaś najpóźniej na zwyczajnym walnym zgromadzeniu w dniu 24 września 2008 r.

Należy jednak wskazać, że prezentowany przez skarżącą sposób oceny jest co najmniej dyskusyjny. Zarówno w toku postępowania administracyjnego, są- 
dowoadministracyjnego, jak i wznowieniowego jedynymi akcjonariuszami skarżącej spółki, dysponującymi wszystkimi 500000 akcji w kapitale zakładowym spółki, byli Andrzej Bonarski i Barbara Kabala-Bonarska. Z udziałem tych osób regularnie odbywały się coroczne (w tym w latach rzekomego braku zarządu, tj. w latach 2006-2015) zwyczajne walne zgromadzenia akcjonariuszy, na których jednym z obligatoryjnych punktów jest udzielenie absolutorium (skwitowania) członkom zarządu, w którym to charakterze również występowali Andrzej Bonarski i Barbara Kabala-Bonarska. Te same osoby są również nieprzerwanie wpisane jako członkowie zarządu w rejestrze przedsiębiorców KRS. W tej sytuacji podnoszenie zarzutu, że mandaty tych osób wygasły w związku z brakiem wskazania „samych siebie” na funkcje członków zarządu w trybie określonym w zmienionym $\$ 19$ ust. 3 statutu spółki, trzeba uznać za niezasadne. Oznaczałoby to bowiem zakwestionowanie ważności i skuteczności decyzji podejmowanych (a przynajmniej aprobowanych) jednomyślnie przez akcjonariuszy będących równocześnie członkami zarządu tylko z tego powodu, że zostały one zaprotokołowane formalnie jako decyzje walnego zgromadzenia, a nie osób fizycznych będących wyłącznymi uczestnikami tego zgromadzenia. Ryzyko, jakie tego typu interpretacja niesie dla stabilności wszelkiego typu postępowań oraz rozstrzygnięć administracyjnych i sądowych - nie tylko przed Naczelnym Sądem Administracyjnym - nie wymaga, jak się zdaje, szerszego komentarza. Wniosek ten należy tym bardziej odnieść do tezy, że te same osoby fizyczne, tym razem już jako prawidłowo ukonstytuowany zarząd skarżącej spółki, „powzięły wiedzę" o podstawie wznowienia postępowania sądowoadministracyjnego przed Naczelnym Sądem Administracyjnym - w znaczeniu, w jakim posługuje się tą przesłanką art. 277 p.p.s.a. - dopiero 28 kwietnia 2015 r., co miało „otworzyć” skarżącej termin na wniesienie skargi o wznowienie postępowania.

Jedynie na marginesie można wskazać, że przepisy ustawy z dnia 15 września 2000 r. - Kodeks spółek handlowych (t.j. Dz. U. 2017, poz. 1577, ze zm.; dalej: k.s.h.) nie przewidują sankcji bezwzględnej nieważności uchwał walnego zgromadzenia akcjonariuszy sprzecznych ze statutem spółki (zob. art. $422 \$ 1$ k.s.h.), zaś orzecznictwo sądowe restryktywnie podchodzi nawet do upadku ze skutkiem ex tunc skuteczności uchwał walnego zgromadzenia akcjonariuszy sprzecznych z ustawą (zob. art. $425 \$ 1$ k.s.h. oraz uchwałę składu 7 sędziów SN z 18 września 2013 r., sygn. akt III CZP 13/13). W aktach sprawy brak zresztą jakichkolwiek informacji na temat tego, aby takie postępowanie kiedykolwiek się toczyło (a jedynie prawomocny wyrok sądu uchylający uchwałę lub stwierdzający jej nieważność mógłby w sposób prejudycjalny i wiążący NSA rozstrzygnąć problem braku właściwej reprezentacji strony w postępowaniu sądowoadministracyjnym).

W związku z powyższym Sejm poddaje pod rozwagę Trybunału Konstytucyjnego ewentualność umorzenia postępowania na podstawie art. 59 ust. 1 pkt 2 u.o.t.p.TK. Uzasadnione wydaje się bowiem twierdzenie, że w stanie faktycznym, stanowiącym podstawę zarówno niniejszego postępowania, jak i postępowania 
wznowieniowego przed Naczelnym Sądem Administracyjnym, nie zachodziła żadna $\mathrm{z}$ ustawowych podstaw wznowienia. Innymi słowy, brak realnego i bezpośredniego interesu skarżącej spółki, którego ochronie miałaby służyć skarga konstytucyjna nakierowana na stwierdzenie niekonstytucyjności art. $173 \$ 1$ p.p.s.a.

5. Za okoliczności uniemożliwiające merytoryczne rozpoznanie skargi nie można natomiast uznać tego, że: (a) ma ona charakter skargi na brak określonej regulacji prawnej (a więc tzw. pominięcie ustawodawcze), jak również (b) odnosi się do normy niewynikającej bezpośrednio z treści przepisu, ale dekodowanej zeń przez orzecznictwo sądowe.

W punkcie pierwszym trzeba przywołać bogate orzecznictwo polskiego sądu konstytucyjnego dotyczące rozróżnienia na podlegające jego kognicji przypadki tzw. pominięcia ustawodawczego oraz wykraczające poza tę kognicję przypadki tzw. zaniechania legislacyjnego. Możliwość kontroli konstytucyjności pominięcia legislacyjnego ( $\mathrm{tj}$. elementu kontrolowanej normy prawnej niezbędnego dla zapewnienia jej zgodności ze standardami konstytucyjnymi) jest dzisiaj bezsporna i nie wymaga szerszego komentarza (tak już TK w orzeczeniu z 3 grudnia 1996 r., sygn. akt K 25/95, i wyroku z 6 maja 1998 r., sygn. akt K 37/97; zob. także wyroki TK z: 9 października 2001 r., sygn. akt SK 8/00; 16 listopada 2004 r., sygn. akt P 19/03; 14 marca 2006 r., sygn. akt SK 4/05; 13 listopada 2007 r., sygn. akt P 42/06; 16 listopada 2012 r., sygn. akt K 2/10).

$\mathrm{W}$ drugim punkcie należy natomiast wskazać, że zgodnie z ustabilizowanym orzecznictwem Trybunału Konstytucyjnego, jakkolwiek przedmiotem kontroli konstytucyjności nie może być konkretny akt stosowania prawa, to organ ten może badać taką treść przepisu, jaką uzyskał on w wyniku jednolitej, powszechnej i stałej wykładni sądowej (zob. postanowienie TK z 16 października 2007 r., sygn. akt SK 13/07). Możliwa jest bowiem sytuacja: „gdy prawo jest sformułowane w taki sposób, że choć nie jest jednoznacznie niekonstytucyjne i mogłoby być właściwie (czyli bez uszczerbku dla praw i wolności) stosowane, to jednak powszechne stosowanie jest niewłaściwe. Wówczas przedmiotem kontroli Trybunału Konstytucyjnego jest norma prawna dekodowana zgodnie z ustaloną praktyką)" (wyrok TK z 24 czerwca 2008 r., sygn. akt SK 16/06; zob. także wyrok TK z 1 września 2006 r., sygn. akt SK 14/05), zwłaszcza w orzecznictwie Sądu Najwyższego. „[S]tałość, powtarzalność i powszechność praktyki sądowej może nadawać kwestionowanemu unormowaniu (...) określone znaczenie, podlegające następnie kontroli konstytucyjności. Stałość i powszechność praktyki, wynikającej z odczytywania przepisów w sposób niekonstytucyjny, powoduje bowiem nadanie samym przepisom trwałego i niekonstytucyjnego znaczenia. (...) Ujawnienie (...) zależności pomiędzy sferą stanowienia i stosowania prawa wymaga jednakże każdorazowo stwierdzenia, czy w istocie rzeczy mamy do czynienia z taką właśnie powtarzalną i powszechną metodą wykładni określonego przepisu (unormowania)" (postanowienie TK z 21 września 2005 r., sygn. SK 32/04). 


\section{Analiza merytoryczna}

\section{- 1. Zarzuty skarżącej}

Skarżąca zarzuca przepisowi art. $173 \$ 1$ p.p.s.a. naruszenie niektórych gwarancji proceduralnych określonych przez ustawę zasadniczą, tj. art. 32 ust. 1, art. 45 ust. 1, art. 77 ust. 2, art. 78 i art. 176 ust. 1 Konstytucji. Zakwestionowany przepis nie przewiduje bowiem możliwości zaskarżenia skargą kasacyjną postanowienia Naczelnego Sądu Administracyjnego odrzucającego postanowienie o odrzuceniu skargi o wznowienie postępowania przed Naczelnym Sądem Administracyjnym, orzekającego po raz pierwszy w tym postępowaniu. W takim wypadku strona powinna mieć bowiem zapewnioną możliwość skontrolowania przez inny sąd lub przynajmniej inny skład tego sądu prawidłowości wydania orzeczenia zamykającego jej drogę do merytorycznego rozpoznania skargi o wznowienie postępowania. Możliwość taka jest szczególnie istotna tam, gdzie o wznowieniu orzeka sąd, którego działanie lub zaniechanie ma związek z podstawą wznowienia, a w szczególności tam, gdzie do wznowienia dochodzi z powodu nieważności postępowania toczącego się przed tym sądem (skarga, s. 10). Tymczasem brak możliwości złożenia środka odwoławczego na postanowienie Naczelnego Sądu Administracyjnego odrzucające skargę o wznowienie postępowania przed Naczelnym Sądem Administracyjnym zamyka drogę do rozpoznania sprawy i nadmiernie ogranicza dostęp do wymiaru sprawiedliwości - bez wystarczającego uzasadnienia. Kwestionowana regulacja bezzasadnie różnicuje również sytuację stron wnoszących skargę o wznowienie postępowania zakończonego orzeczeniem wojewódzkiego sądu administracyjnego i Naczelnego Sądu Administracyjnego: $w$ tym pierwszym wypadku nie ulega bowiem wątpliwości, że na postanowienie WSA o odrzuceniu skargi o wznowienie przysługuje skarga kasacyjna do NSA (skarga, s. 13). Wreszcie, art. $173 \$ 1$ p.p.s.a., w zakresie wskazanym na wstępie, godzi w prawo do kwestionowania orzeczeń sądowych wydanych w pierwszej instancji „W ogóle” powiązane z zasadą dwuinstancyjności postępowania sądowego (skarga, s. 14).

\section{Wzorce kontroli}

- a) Zasada równości

1. Zgodnie z art. 32 ust. 1 Konstytucji: „Wszyscy są wobec prawa równi. Wszyscy mają prawo do równego traktowania przez władze publiczne".

2. Zasada równości, według ustabilizowanego orzecznictwa Trybunału Konstytucyjnego: „polega na tym, że wszystkie podmioty prawa (adresaci norm prawnych), charakteryzujący się daną cechą istotną (relewantną) w równym stopniu, mają być traktowani równo, a więc według jednakowej miary, bez zróżnicowań zarówno dyskryminujących, jak i faworyzujących" (tak fundamentalne w tej mierze orzeczenie TK z 9 marca 1988 r., sygn. akt U 7/87; zob. również 
późniejsze wyroki TK z: 6 maja 1998 r., sygn. akt K 37/97; 24 października 2001 r., sygn. akt SK 22/01; 2 kwietnia 2003 r., sygn. akt K 13/02; 3 marca 2004 r., sygn. akt K 29/03; 19 grudnia 2007 r., sygn. akt K 52/05). Punktem wyjścia powinno więc być ustalenie, czy istnieje wspólność cechy relewantnej pomiędzy porównywanymi sytuacjami, a więc, innymi słowy, czy zachodzi „podobieństwo” tych sytuacji. Jeżeli zostaje stwierdzone, że sytuacje „podobne” zostały przez prawo potraktowane odmiennie, to wskazuje to na możliwość naruszenia zasady równości.

3. Trybunał Konstytucyjny uznaje, że odmienność potraktowania sytuacji podobnych nie zawsze jest konstytucyjnie niedopuszczalna; mogą bowiem zachodzić wypadki, gdy jest ona usprawiedliwiona. Wszelkie odstępstwa od nakazu równego traktowania podmiotów podobnych muszą jednak zawsze znajdować uzasadnienie w odpowiednio przekonujących argumentach, nawiązujących do sposobu ujęcia zasady proporcjonalności. Argumenty te muszą mieć charakter: 1) relewantny, a więc pozostawać w bezpośrednim związku z celem i zasadniczą treścią przepisów, w których zawarta jest kontrolowana norma, oraz służyć realizacji tego celu i treści (innymi słowy, wprowadzane zróżnicowania muszą mieć charakter racjonalnie uzasadniony); 2) proporcjonalny, a więc waga interesu, któremu ma służyć różnicowanie sytuacji adresatów normy, musi pozostawać w odpowiedniej proporcji do wagi interesów, które zostaną naruszone w wyniku nierównego potraktowania podmiotów podobnych; 3) pozostawać w jakimś związku z innymi wartościami, zasadami czy normami konstytucyjnymi, uzasadniającymi odmienne potraktowanie podmiotów podobnych (zob. orzeczenie TK z 3 września 1996 r., sygn. akt K 10/96). Dopiero brak przekonujących argumentów powoduje, że regulacja różnicująca reżim prawny podmiotów czy sytuacji „podobnych” nabiera charakteru niekonstytucyjnej dyskryminacji bądź uprzywilejowania (zob. przykładowo wyrok TK z 3 kwietnia 2008 r., sygn. akt K 6/05).

\section{- b) Prawo do sądu}

1. Zgodnie z art. 45 ust. 1 Konstytucji: „Każdy ma prawo do sprawiedliwego i jawnego rozpatrzenia sprawy bez nieuzasadnionej zwłoki przez właściwy, niezależny, bezstronny i niezawisły sąd."

2. Prawo do sądu, stanowiące jedno z podstawowych praw jednostki i jedną z fundamentalnych gwarancji praworządności, było już wielokrotnie przedmiotem wypowiedzi Trybunału Konstytucyjnego (zob. m.in. wyroki TK z: 9 czerwca 1998 r., sygn. akt K 28/97; 16 marca 1999 r., sygn. akt SK 19/98; 14 grudnia 1999 r., sygn. akt SK 14/98; 10 maja 2000 r., sygn. akt K 21/99; 10 lipca 2000 r., sygn. akt SK 12/99; 19 lutego 2003 r., sygn. akt P 11/02; 24 października 2007 r., sygn. akt SK 7/06). Według ustabilizowanego orzecznictwa Trybunału na konstytucyjne prawo do sądu składa się w szczególności: 1) prawo dostępu do sądu, tj. prawo uruchomienia procedury przed sądem;2) prawo do odpowiednio ukształtowanej procedury sądowej, zgodnej z wymogami sprawiedliwości i jawności; 3) prawo do wyroku sądowego, tj. prawo do uzyskania wiążącego rozstrzygnięcia sprawy 
przez sąd; 4) prawo do odpowiedniego ukształtowania ustroju i pozycji organów rozpoznających sprawy. Trybunał wyjaśnia ponadto w swoim orzecznictwie, że konstytucyjne prawo do sądu ma dwa aspekty: 1) pozytywny, bo zawiera dyrektywy zobowiązujące ustawodawcę do należytego ukształtowania systemu wymiaru sprawiedliwości w wymiarze instytucjonalnym i proceduralnym oraz zobowiązujące do zapewnienia jego efektywnego funkcjonowania; 2) negatywny, wyrażający się w zakazie zamykania lub nadmiernego ograniczania dostępu do wymiaru sprawiedliwości (art. 45 ust. 1 w związku z art. 77 ust. 2 Konstytucji).

Zarówno w orzecznictwie Trybunału Konstytucyjnego, jak i w doktrynie prawa jest przy tym bezsporne, że prawo do sądu nie ma charakteru absolutnego. Tytułem przykładu można przywołać wyrok Trybunału z 10 maja 2000 r. (sygn. akt SK 21/99), w którym podkreślono, że: „(...) nie istnieje w żadnym systemie prawnym bezwzględne i absolutne prawo do sądu - które nie podlegałoby jakimkolwiek ograniczeniom i które w konsekwencji stwarzałoby uprawnionemu nieograniczoną możliwość ochrony swych praw na drodze sądowej. To stwierdzenie należy odnieść do wszystkich kategorii praw, bowiem samo ukształtowanie postępowania przed sądem w sposób respektujący określone procedury (...) stanowi istotne i rzeczywiste ograniczenie prawa do sądu, konieczne jednak ze względu na inne wartości powszechnie szanowane w państwie prawnym, jak w szczególności bezpieczeństwo prawne, zasada legalizmu czy zaufanie do prawa" (zob. także wyroki TK z: 7 września 2004 r., sygn. akt P 4/04 i 16 grudnia 2008 r., sygn. akt P 17/07). W opinii Trybunału Konstytucja nie wyklucza ustanawiania w ustawie ograniczeń prawa do sądu, jeżeli nie prowadzą do zamknięcia sądowej drogi dochodzenia konstytucyjnych wolności i praw oraz mieszczą się w ramach określonych przez art. 31 ust. 3 Konstytucji, wyznaczający granice ingerencji organów władzy publicznej w tej sferze (zob. wyrok TK z 12 września 2006 r., sygn. akt SK 21/05).

3. W kontekście podnoszonych przez skarżącą zarzutów istotne mogą okazać się dwa tradycyjnie wyodrębniane aspekty prawa do sądu, tj. prawo dostępu do sądu oraz zasada tzw. sprawiedliwości proceduralnej.

Prawo dostępu do sądu było przedmiotem licznych wypowiedzi Trybunału Konstytucyjnego (zob. m.in. wyroki TK z: 8 grudnia 1998 r., sygn. akt K 41/97; 16 marca 1999 r., sygn. akt SK 19/98; 14 września 1999 r., sygn. akt K 14/98; 16 listopada 1999 r., sygn. akt SK 11/99; 27 lutego 2001 r., sygn. akt K 22/00; 11 września 2001 r., sygn. akt SK 17/00; 8 października 2002 r., sygn. akt K 36/00; 10 maja 2004 r., sygn. akt SK 39/03; 4 marca 2008 r., sygn. akt SK 3/07; 2 września 2008 r., sygn. akt K 35/06; 17 listopada 2009 r., sygn. akt SK 64/08). Obszernego podsumowania swojego dotychczasowego orzecznictwa w tej mierze dokonał zaś Trybunał w wyroku z 29 czerwca 2010 r. (sygn. akt P 28/09), wskazując m.in., że: „[z] art. 45 Konstytucji wynika jednoznacznie wola prawodawcy, aby prawem do sądu objąć możliwie najszerszy zakres spraw”. Brak możliwości wprowadzania wyłączeń od zasady sądowego wymiaru sprawiedliwości Trybunał potwierdził zresztą już w wyroku z 14 września 1999 r. (sygn. akt K 14/98), wskazując, że: 
„(...) jedynymi instytucjami powołanymi do ostatecznego rozstrzygania o obowiązkach, prawach i wolnościach obywateli są niezawisłe sądy, które z mocy Konstytucji mają gwarantować tym obywatelom, że ich prawa nie będą naruszane zarówno przed organami państwa, jak i przed organami organizacji społecznych".

Prawo do sądu musi być przy tym rozumiane zarówno formalnie - jako dostępność drogi sądowej w ogóle, jak i materialnie - jako możliwość prawnie skutecznej ochrony praw na drodze sądowej. Ochronę taką gwarantuje ukształtowanie warunków realizacji tego prawa w taki sposób, który nie prowadzi do ograniczenia możliwości merytorycznego zbadania przez sąd zarzutów formułowanych przez skarżącego (zob. np. wyrok TK z 31 stycznia 2005 r., sygn. akt SK 27/03).

4. Znaczenie nakazu rzetelności postępowania, ujmowanego niekiedy także $\mathrm{w}$ postaci tzw. zasady sprawiedliwości proceduralnej, było kilkukrotnie podkreślane przez polski sąd konstytucyjny (zob. m.in. wyrok TK z 16 stycznia 2006 r., sygn. akt SK 30/05). Różne koncepcje sprawiedliwości proceduralnej mają wspólny rdzeń, który sprowadza się do: (1) możności bycia wysłuchanym; (2) ujawniania w czytelny sposób motywów rozstrzygnięcia, w stopniu umożliwiającym weryfikację sposobu myślenia sądu (i to nawet jeśli samo rozstrzygnięcie jest niezaskarżalne - legitymizacja przez przejrzystość), a więc unikania dowolności czy wręcz arbitralności w działaniu sądu; (3) zapewnienia przewidywalności dla uczestnika postępowania, przez odpowiednią spójność i wewnętrzną logikę mechanizmów, którym jest poddany.

Trybunał Konstytucyjny sprecyzował treść zasady sprawiedliwości proceduralnej (rzetelności proceduralnej) przede wszystkim przy okazji badania konstytucyjności przepisów normujących środki zaskarżenia w postępowaniu cywilnym. Istotne znaczenie mają tutaj w szczególności wyroki z: 20 maja 2008 r. (sygn. akt P 18/07) i 1 lipca 2008 r. (sygn. akt SK 40/07), w których Trybunał stwierdził niekonstytucyjność przepisów procedury cywilnej przewidujących odrzucenie przez sąd, odpowiednio, apelacji i skargi kasacyjnej sporządzonej przez profesjonalnego pełnomocnika, niespełniającej określonych wymagań prawnych, bez wzywania do usunięcia braków (art. $370^{1}$ i art. $398^{6} \$ 2$ i $\$ 3$ Kodeksu postępowania cywilnego; zob. także wyroki TK z: 12 marca 2002 r., sygn. akt P 9/01, i 16 stycznia 2006 r., sygn. akt SK 30/05). W przywołanych orzeczeniach Trybunał dyskwalifikował, najogólniej rzecz biorąc, regulacje wprowadzające określone rygory formalne, przekraczające "górną granicę formalizmu procesowego", a w efekcie uniemożliwiające merytoryczne rozpatrzenie sprawy.

- c) Zakaz zamykania drogi sądowej

1. Zgodnie z art. 77 ust. 2 Konstytucji: „Ustawa nie może nikomu zamykać drogi sądowej dochodzenia naruszonych wolności lub praw".

2. Zarówno w orzecznictwie Trybunału Konstytucyjnego, jak i piśmiennictwie podkreśla się, że art. 45 ust. 1 i art. 77 ust. 2 Konstytucji ustanawiają kon- 
stytucyjne gwarancje prawa do sądu; powinny one przy tym być odczytywane łącznie, istnieje bowiem między nimi ścisły związek („organiczna więź”). Przyjęty przez ustrojodawcę sposób regulacji podkreśla dwoisty charakter prawa do sądu: jako środka ochrony innych wolności i praw oraz jako odrębnego, samodzielnego prawa podmiotowego (zob. m.in. wyroki TK z: 9 czerwca 1998 r., sygn. akt K 28/97; 14 czerwca 1999 r., sygn. akt K 11/98; 16 marca 1999 r., sygn. akt SK 19/98; a także: Z. Czeszejko-Sochacki, Prawo do sadu w świetle Konstytucji Rzeczypospolitej Polskiej, „Państwo i Prawo” 1997, z. 11-12; H. Pietrzykowski, Prawo do sądu, „Przegląd Sądowy” 1999, nr 11-12; P. Tuleja [w:] Prawo konstytucyjne RP, red. P. Sarnecki, Warszawa 1999).

W podstawowym w tej mierze wyroku z 10 maja 2000 r. (sygn. akt K 21/99). Trybunał stwierdził m.in.: „O ile art. 45 ust. 1 pozytywnie formułuje prawo do sądu, o tyle art. 77 ust. 2 zawiera zakaz zamykania drogi sądowej dla dochodzenia naruszonych wolności i praw, stanowi zatem dopełnienie (uzupełnienie, rozwinięcie) prawa do sądu. (...) Z ustaleń powyższych nie wynika jeszcze tożsamość ujęcia przedmiotowego obu przepisów zawierających gwarancję prawa do sądu od strony pozytywnej i negatywnej. (...) Jeśli więc art. 45 ust. 1 Konstytucji dotyczy dochodzenia przed sądem wszelkich praw (także ustanowionych w innych aktach normatywnych niż Konstytucja), to art. 77 ust. 2 Konstytucji obejmuje swym zakresem jedynie prawa i wolności gwarantowane konstytucyjnie. W tym znaczeniu art. 77 ust. 2, stanowiąc uzupełnienie i rozwinięcie ogólniejszego ujęcia $\mathrm{z}$ art. 45 ust. 1, zawiera zarazem swoistą regulację szczególną w stosunku do art. 45 ust. 1 Konstytucji. Płynie stąd istotny wniosek co do zakresu dopuszczalnych ograniczeń prawa do sądu. Ograniczenia prawa do sądu ustanawiane normą ustawową, stosownie do art. 31 ust. 3 Konstytucji, muszą uwzględniać kategoryczny zakaz zamykania drogi do sądu zawarty w art. 77 ust. 2 w zakresie dochodzenia konstytucyjnych wolności i praw, ergo wyłączenie drogi sądowej w sprawach związanych z naruszeniem wolności i praw może być ustanowione jedynie wprost przepisami konstytucyjnymi. (...) W tym sensie art. 77 ust. 2 Konstytucji wyznacza, obok art. 31 ust. 3, zakres dopuszczalnych ograniczeń prawa do sądu. (...) W konsekwencji, należy więc stwierdzić, że konieczność ochrony w demokratycznym państwie takich wartości jak: bezpieczeństwo państwa, porządek publiczny, ochrona środowiska, zdrowia i moralności publicznej, wolności i praw innych osób nie może uzasadniać zamknięcia drogi sądowej w odniesieniu do praw objętych zakresem zastosowania art. 77 ust. 2 Konstytucji, może natomiast co najwyżej uzasadniać pewne ograniczenia ochrony sądowej, przejawiające się w odmiennym ukształtowaniu zasad postępowania sądowego w stosunku do ogólnych reguł proceduralnych".

- d) Prawo do zaskarżania orzeczeń i decyzji wydanych w pierwszej instancji 1. Artykuł 78 Konstytucji stanowi: „Każda ze stron ma prawo do zaskarżenia orzeczeń i decyzji wydanych w pierwszej instancji. Wyjątki od tej zasady oraz 
tryb zaskarżania określa ustawa”. Norma ta w pewnym sensie uzupełnia konstytucyjne gwarancje prawa do sądu (art. 45 ust. 1 Konstytucji) oraz zasadę dwuinstancyjności postępowania sądowego (ar. 176 ust. 1 Konstytucji).

2. W doktrynie podkreśla się, że termin „zaskarżenie” nie został zdefiniowany w przywołanym postanowieniu Konstytucji. Pozwala to na jego szerokie rozumienie, a tym samym objęcie jego zakresem różnych, specyficznych dla danej procedury, środków prawnych, których cechą wspólną jest umożliwienie stronie weryfikacji podjętego w pierwszej instancji orzeczenia bądź decyzji (zob. B. Banaszak, Konstytucja RP. Komentarz, Warszawa 2009, s. 393). Z kolei Trybunał Konstytucyjny przyjął, że: „(...) chodzi tu o środki prawne, uruchamiające tzw. kontrolę instancyjną (tok instancji), a więc zwyczajne środki prawne (środki odwoławcze) o charakterze w zasadzie dewolutywnym. Przepis ten, literalnie rzecz ujmując, nie odnosi się do nadzwyczajnych środków prawnych, choć obejmuje naturalnie także postępowania, toczące się $\mathrm{w}$ wyniku złożenia wniosku o stwierdzenie nieważności czy wznowienie postępowania" (wyrok TK z 15 maja 2000 r., sygn. akt SK 29/99; zob. także wyrok TK z 12 stycznia 2010 r., sygn. akt SK 2/09). Konstytucyjny standard $\mathrm{w}$ tym zakresie wyczerpuje się $\mathrm{w}$ możliwości poddania weryfikacji jedynie niekontrolowanego uprzednio rozstrzygnięcia $w$ ramach rozpoczętej już sprawy.

Instancyjność, związana z oceną procesu decyzyjnego, który legł u podstaw pierwszego rozstrzygnięcia w sprawie, a nie jedynie z oceną faktów lub rozstrzyganiem kwestii incydentalnych (zob. postanowienie TK z 12 września 2007 r., sygn. akt Ts 168/06; a także T. Zembrzuski, Zaskarżanie orzeczeń incydentalnych wydanych po raz pierwszy w toku instancji (uwagi na tle wyroku Trybunatu Konstytucyjnego), „Przegląd Sądowy” 2007, nr 9, s. 23), ma ograniczać ryzyko rozstrzygnięć błędnych lub arbitralnych. W tym też sensie prawo do zaskarżania rozstrzygnięć zapadłych w pierwszej instancji wzmacnia konstytucyjne gwarancje prawa do sądu, zwłaszcza w aspekcie tzw. sprawiedliwości proceduralnej.

- e) Zasada dwuinstancyjności postępowania sądowego

1. Zgodnie z art. 176 ust. 1 Konstytucji: „Postępowanie sądowe jest co najmniej dwuinstancyjne".

2. Wyrażona $\mathrm{w}$ cytowanym przepisie zasada dwuinstancyjności postępowania sądowego ma charakter bezwzględny. Artykuł 176 ust. 1 Konstytucji dotyczy jednak tylko spraw przekazanych ustawami do wyłącznej właściwości sądów, tzn. rozpoznawanych przez nie „od początku do końca” (zob. wyroki TK z: 8 grudnia 1998 r., sygn. akt K 41/97; 11 czerwca 2002 r., sygn. akt SK 5/02; 12 maja 2003 r., sygn. akt SK 38/02; 13 czerwca 2006 r., sygn. akt SK 54/04). Z tego względu jest on - w pewnym sensie - „dopełnieniem” art. 78 Konstytucji (zob. wyrok TK z 12 czerwca 2002 r., sygn. akt P 13/01). Podkreśla się ponadto, że art. 176 ust. 1 Konstytucji ma dwojaki charakter. Z jednej strony jest on przepisem ustrojowym, ponieważ określa sposób zorganizowania procedur sądowych, a w kon- 
sekwencji sposób zorganizowania systemu sądów. Z drugiej strony jest też przepisem gwarancyjnym, bo konkretyzuje i dopełnia ogólną zasadę zawartą w art. 78 Konstytucji, posiadając również „samoistne znaczenie prawne”. Wyrażana bywa też opinia, że z treści art. 176 ust. 1 Konstytucji wynika prawo „każdego” do drugiej instancji; może być on więc rozpatrywany w kategoriach przepisów regulujących prawa jednostki (zob. L. Garlicki, Komentarz do art. 176 [w:] Konstytucja Rzeczypospolitej Polskiej. Komentarz, red. L. Garlicki, t. IV, Warszawa 2005, s. 1-2; zob. także wyrok TK z 13 lipca 2009 r., sygn. akt SK 46/08, oraz postanowienia TK z: 8 czerwca 2009 r., sygn. akt SK 26/07, i 21 lipca 2009 r., sygn. akt SK 61/08).

3. Konstytucyjna zasada dwuinstancyjności postępowania nie jest natomiast jak wskazuje się we wcześniejszym orzecznictwie Trybunału - elementem prawa do sądu (zob. wyroki TK z: 8 grudnia 1998 r., sygn. akt K 41/97; 10 lipca 2000 r., sygn. akt SK 12/99; zob. także A. Jakubecki, Kilka uwag o instancyjności postępowania cywilnego na tle orzecznictwa Trybunału Konstytucyjnego [w:] Orzecznictwo Trybunału Konstytucyjnego a Kodeks postępowania cywilnego, red. T. Ereciński, K. Weitz, Warszawa 2010, s. 81 i n., oraz M. Pilich, Wpływ orzeczeń Trybunału Konstytucyjnego na Kodeks postępowania cywilnego [w:] Orzecznictwo Trybunału Konstytucyjnego a Kodeks postępowania cywilnego, red. T. Ereciński, K. Weitz, Warszawa 2010, s. 375-396). Zasada dwuinstancyjności wzmacnia jednak to prawo, umożliwiając proceduralną kontrolę postępowania sądowego. Trybunał wielokrotnie podkreślał, że „celem reguły instancyjności jest zapobieganie pomyłkom i arbitralności w pierwszej instancji” (wyrok TK z 12 czerwca 2002 r., sygn. akt P 13/01), „konstytucyjne prawo zaskarżania orzeczeń i decyzji wydanych w pierwszej instancji stanowi bardzo istotny czynnik urzeczywistniania tzw. sprawiedliwości proceduralnej” (wyrok TK z 16 listopada 1999 r., sygn. akt SK 11/99), a „ustawy regulujące postępowanie sądowe muszą w szczególności w sposób precyzyjny normować prawa stron oraz zaskarżanie orzeczeń sądowych" (wyrok TK z 19 lutego 2003 r., sygn. akt P 11/02; zob. także wyrok TK z 27 marca 2007 r., sygn. akt 3/05).

\section{Analiza zgodności}

1. Instytucja wznowienia postępowania sądowoadministracyjnego, uregulowana w dziale VII p.p.s.a., a ściślej - inicjująca to szczególne postępowanie skarga, ma charakter nadzwyczajnego środka prawnego. Wyjątkowy charakter wznowienia postępowania sądowoadministracyjnego wynika z faktu, że skarga o wznowienie przysługuje wyłącznie od prawomocnych orzeczeń kończących postępowanie i musi być oparta na podstawach określonych w ustawie. W literaturze przedmiotu wskazuje się, że instytucja ta polega na ponownym rozpoznaniu i rozstrzygnięciu sprawy zakończonej prawomocnym orzeczeniem w przypadku zajścia ustawowych przyczyn wznowienia (zob. J.P. Tarno, Prawo o postępowaniu przed sadami administracyjnymi. Komentarz, Warszawa 2011, s. 617), stanowiąc podstawowy środek obalania prawomocnych orzeczeń NSA i WSA, umożliwiający ponowne 
rozpoznanie i rozstrzygnięcie sprawy co do jej istoty w celu zagwarantowania prawidłowości (tj. zgodności z prawem) wydanego w sprawie rozstrzygnięcia (zob. B. Adamiak [w:] B. Adamiak, J. Borkowski, Postępowanie administracyjne i sądowoadministracyjne, Warszawa 2015, s. 476) oraz zapewnienia racjonalnej stabilności merytorycznego orzeczenia i autorytetu sądu, który je wydał (zob. K. Sobieralski, Wznowienie postępowania sądowoadministracyjnego, Warszawa 2013, s. 49-50).

Skargę o wznowienie postępowania sądowoadministracyjnego może wnieść strona, uczestnik postępowania, prokurator, Rzecznik Praw Obywatelskich lub Rzecznik Praw Dziecka. Zastosowanie instytucji wznowienia postępowania jest możliwe wyłącznie w odniesieniu do orzeczeń prawomocnych, kończących postępowanie, od których nie przysługuje środek odwoławczy (art. 270 p.p.s.a.; zob. postanowienia NSA z: 16 listopada 2005 r., sygn. akt I OZ 299/05; 25 listopada 2011 r., sygn. akt I OSK 887/11, oraz 13 lutego 2008 r., sygn. akt I OSK 112/07). Na tle przepisów ustawy - Prawo o postępowaniu przed sądami administracyjnymi można żądać wznowienia postępowania, co do zasady, zarówno wtedy, gdy sąd prawomocnie orzekł w sprawie wyrokiem, jak również, gdy zakończył postępowanie wydaniem postanowienia (np. postanowienie NSA o odrzuceniu skargi kasacyjnej; zob. A. Kabat [w:] B. Dauter, B. Gruszczyński, A. Kabat, M. Niezgódka-Medek, Prawo o postępowaniu przed sądami administracyjnymi. Komentarz, 2013, LEX, s. 781; W. Maciejko, Wznowienie postępowania sadowoadministracyjnego na skutek wyroku Trybunału Konstytucyjnego, „Casus. Kwartalnik Krajowej Reprezentacji Samorządowych Kolegiów Odwoławczych” 2006, nr 39, s. 7; J.P. Tarno, Prawo o postępowaniu, op. cit., s. 618). Przepisy o wznowieniu postępowania nie mają zastosowania do postanowień o charakterze procesowym, które nie kończą sprawy (incydentalnych, wpadkowych), takich jak np. postanowienie o wyłączeniu bądź o odmowie wyłączenia sędziów (sędziego; zob. postanowienia NSA z: 14 lutego 1997 r., sygn. akt I SA 1468/96; 26 czerwca 2006 r., sygn. akt I GSK 240/06; 29 listopada 2006 r., sygn. akt I OZ 1560/06; 28 marca 2006 r., sygn. akt II OZ 1456/05), postanowienie w przedmiocie rozstrzygnięcia wątpliwości co do treści wyroku (postanowienie NSA z 16 marca 2006 r., sygn. akt I OSK 264/06), czy też w przedmiocie przywrócenia uchybionego terminu (postanowienie NSA z 16 listopada 2005 r., sygn. akt I OZ 299/05).

2. Przesłanki (podstawy) wznowienia postępowania przed sądami administracyjnymi systematyzuje się na cztery grupy: 1) nieważność postępowania (art. 271 p.p.s.a.), 2) tzw. właściwe przyczyny restytucyjne (art. 273 p.p.s.a.), 3) niekonstytucyjność podstawy orzeczenia (art. $272 \$ 1$ p.p.s.a.) oraz 4 ) niezgodność podstawy orzeczenia ze standardami międzynarodowymi (art. $272 \$ 3$ p.p.s.a.). Możliwość wznowienia postępowania jest przy tym ograniczona dwojakimi terminami: art. $272 \$ 2$ i art. 277 p.p.s.a. wprowadzają trzymiesięczny, procesowy termin na wniesienie skargi liczony od uzyskania wiedzy o podstawie wznowienia, zaś art. 278 p.p.s.a. ogólny, maksymalny i zbliżony do terminu prekluzyjnego prawa materialnego pięcioletni termin obowiązujący przy wnosze- 
niu skargi o wznowienie postępowania sądowoadministracyjnego. Ustawodawca przyjął w ten sposób, że trzymiesięczny termin na wniesienie skargi (art. $272 \$ 2$ i art. 277 p.p.s.a.) określa czasową dopuszczalność żądania wznowienia postępowania, opierającą się na powiązaniu podstawy wznowienia ze świadomością strony co do istnienia tej podstawy („termin liczy się od dnia, w którym strona dowiedziała się o podstawie wznowienia”), natomiast art. 278 p.p.s.a. wskazuje dodatkową przesłankę, to znaczy czas (okres), w którym możliwe jest wznowienie postępowania w ogóle. W rezultacie skarga o wznowienie postępowania wniesiona z zachowaniem terminów określonych w art. $272 \$ 2$ i 3 lub art. 277 p.p.s.a., ale po upływie terminu przewidzianego w art. 278, podlega odrzuceniu na posiedzeniu niejawnym, bez konieczności badania merytorycznej zasadności wskazanych w niej podstaw - z wyjątkiem zajścia jednej z dwóch sytuacji: jeżeli strona była pozbawiona możliwości działania albo nie była należycie reprezentowana (zob. A. Kabat, Komentarz do art. 278 [w:] B. Dauter, B. Gruszczyński, A. Kabat, M. Niezgódka-Medek, Prawo o postępowaniu, op. cit.; H. Knysiak-Molczyk [w:] Postępowanie sądowoadministracyjne, red. T. Woś, Warszawa 2004, s. 341).

3. Zgodnie z art. 275 p.p.s.a. do wznowienia postępowania z przyczyn nieważności właściwy jest sąd, który wydał zaskarżone orzeczenie, a jeżeli zaskarżono orzeczenia sądów obu instancji - Naczelny Sąd Administracyjny. Do wznowienia postępowania na innej podstawie właściwy jest sąd, który ostatnio orzekał w sprawie. Procedura rozpoznawania skargi o wznowienie - poza kwestionowaną w niniejszym postępowaniu możliwością zaskarżenia postanowienia o odrzuceniu skargi - nie doznaje jednak istotniejszych różnic w zależności od tego, jaki sąd jest właściwy do jej rozpoznania. Stosownie do art. 276 p.p.s.a., w sprawach nieuregulowanych w dziale VII do skargi o wznowienie postępowania należy odpowiednio stosować przepisy o postępowaniu przed sądem administracyjnym pierwszej instancji. Zastosowanie znajdą więc m.in. przepisy regulujące skład sądu (art. 16-17 p.p.s.a.), wyłączenie sędziego (art. 18-24 p.p.s.a.), pisma w postępowaniu sądowym (art. 45-49 p.p.s.a.) itp. Z kolei do skargi o wznowienie postępowania wnoszonej do Naczelnego Sądu Administracyjnego stosuje się odpowiednio art. 175 p.p.s.a. Oznacza to, że taka skarga musi być sporządzona przez adwokata, radcę prawnego lub inną osobę wymienioną $\mathrm{w}$ tym przepisie (zob. postanowienie NSA z 9 marca 2005 r., sygn. akt I GSK 359/05).

Skarga o wznowienie postępowania powoduje uruchomienie dwufazowego postępowania, mającego na celu zbadanie jej dopuszczalności, a następnie, jeśli to zostanie potwierdzone, zbadanie jej zasadności (zob. postanowienia NSA z: 16 listopada 2005 r., sygn. akt I OZ 299/05, i 4 września 2013 r., sygn. akt I FSK 1424/13; zob. także H. Knysiak-Molczyk [w:] Prawo o postępowaniu, op. cit., s. 915). Zgodnie z wyrokiem NSA z 17 sierpnia 2012 r. (sygn. akt I FSK 281/12) pierwszy etap polega na ustaleniu, czy w sprawie ziściła się przesłanka wznowieniowa, która otwiera możliwość ponownego zbadania sprawy oraz zacho- 
wania terminu do wniesienia skargi. W kontekście okoliczności, jakie wystąpiły $\mathrm{w}$ sprawie skarżącej, warto przywołać w tym miejscu pogląd wyrażony w postanowieniu NSA z 2 grudnia 2014 r. (sygn. akt I FSK 2189/13), wedle którego samo sformułowanie podstawy wznowienia w sposób odpowiadający przepisom art. 271-274 p.p.s.a. nie oznacza, że skarga opiera się na ustawowej podstawie wznowienia, jeżeli już z jej uzasadnienia wynika, że podnoszona podstawa nie zachodzi. Drugi etap dotyczy stricte ponownego rozstrzygnięcia sporu, który był przedmiotem orzeczenia, zakwestionowanego w tym nadzwyczajnym trybie. Rozpoznanie zasadności podstaw skargi o wznowienie postępowania następuje wyłącznie na rozprawie. W zakresie badania podstaw wznowienia na posiedzeniu niejawnym mieści się jedynie stwierdzenie, czy skarżący wskazuje podstawę wznowienia i czy odpowiada ona jednej z podanych w ustawie - Prawo o postępowaniu przed sądami administracyjnymi przyczyn uzasadniających żądanie wznowienia, a nie ustalenie, czy podstawa ta rzeczywiście istnieje lub jest trafna (zob. wyrok WSA w Warszawie z 14 marca 2006 r., sygn. akt V SA/Wa 2660/05). Dopiero na rozprawie sąd bada merytoryczne występowanie ustawowej podstawy wznowienia, a negatywny wynik tej oceny powoduje oddalenie skargi o wznowienie (zob. postanowienie NSA z 26 października 2012 r., sygn. akt II OSK 2577/12).

4. W związku z treścią art. $15 \$ 1$ pkt 1 , art. $173 \$ 1$ oraz art. 194 p.p.s.a. $\mathrm{w}$ orzecznictwie i doktrynie jednolicie przyjmuje się zwalczaną przez skarżącą tezę, iż skarga kasacyjna przysługuje - jako jedyny dopuszczalny środek zaskarżenia wyłącznie od orzeczeń wojewódzkiego sądu administracyjnego w przedmiocie wznowienia postępowania (chodzi zarówno o postanowienia o odrzuceniu, jak i oddaleniu skargi; zob. A. Kabat [w:] B. Dauter, B. Gruszczyński, A. Kabat, M. Niezgódka-Medek, Prawo o postępowaniu przed sqadami administracyjnymi. Komentarz, 2016, LEX).

5. Trybunał Konstytucyjny już kilkukrotnie wypowiadał się na temat konstytucyjnych aspektów instytucji wznowienia postępowania. Konsekwentnie rozróżnia on przy tym wznowienie postępowania w ujęciu art. 190 ust. 4 Konstytucji - jako instytucję służącą sanowaniu rozstrzygnięć wydanych na podstawie przepisów uznanych za niezgodne $\mathrm{z}$ ustawą zasadniczą (wznowienie postępowania sensu largo, wznowienie postępowania w ujęciu konstytucyjnym), oraz wznowienie postępowania $\mathrm{w}$ ujęciu gałęziowym - jako ustawowo uregulowany instrument wzruszania prawomocnych orzeczeń i decyzji na gruncie poszczególnych procedur (wznowienie postępowania sensu stricto, wznowienie postępowania w ujęciu technicznym).

Rozróżnienie wznowienia postępowania w ujęciu konstytucyjnym i gałęziowym (technicznym) oraz leżące u jego podstaw różnice aksjologiczne, systemowe i funkcjonalne mają istotne znaczenie także dla problemu „prawa do wznowienia postępowania". W orzecznictwie sądu konstytucyjnego utrwalona jest bowiem teza o istnieniu uprawnienia (prawa podmiotowego) do wznowienia po- 
stępowania po wyroku Trybunału Konstytucyjnego stwierdzającym niezgodność przepisu, na podstawie którego zapadło prawomocne orzeczenie lub ostateczna decyzja. Uprawnienie to jest sytuowane zarówno w kontekście art. 190 ust. 4, jak i art. 45 ust. 1 Konstytucji (zob. m.in. wyroki TK z: 7 września 2006 r., sygn. akt SK 60/05; 28 listopada 2006 r., sygn. akt SK 19/05; 20 października 2009 r., sygn. akt SK 6/09). Nawet w tym wypadku, mimo wyraźnej podstawy konstytucyjnej, Trybunał uznaje jednak, że uprawnienie do wznowienia postępowania nie ma charakteru absolutnego (zob. przykładowo wyroki TK z: 28 listopada 2006 r., sygn. akt SK 19/05; 20 października 2009 r., sygn. akt SK 6/09; 24 listopada 2009 r., sygn. akt SK 36/07). W sporadycznych wypadkach o pozbawieniu możliwości wznowienia postępowania decyduje zresztą - z różnych względów - sam Trybunał (zob. przykładowo wyroki TK z: 24 października 2007 r., sygn. akt SK 7/06; 29 listopada 2007 r., sygn. akt SK 43/06; 27 maja 2008 r., sygn. akt SK 57/06).

O równie jednoznaczną ocenę trudno natomiast w odniesieniu do wznowienia postępowania $\mathrm{w}$ ujęciu gałęziowym. Według dominującego nurtu orzecznictwa Trybunału Konstytucyjnego, z art. 45 ust. 1 Konstytucji nie wynika uprawnienie do żądania („prawo do”) wznowienia postępowania czy też szerzej - do żądania ponownego rozpoznania sprawy zakończonej prawomocnym orzeczeniem sądowym. Skargom konstytucyjnym, w których kwestionowane były - z punktu widzenia zgodności z art. 45 ust. 1 oraz art. 77 ust. 2 Konstytucji - przepisy zamykające dostęp do tego rodzaju środków prawnych, odmawiano nadania dalszego biegu bądź też zapoczątkowane nimi sprawy umarzano z powodu niedopuszczalności wydania wyroku. Przykładem tej linii orzeczniczej jest postanowienie Trybunału Konstytucyjnego z 28 maja 2003 r. (sygn. akt SK 33/02), w którym wskazano m.in.: „Uznanie prawa do sądu za jedno z fundamentalnych dla demokratycznego państwa prawnego nie oznacza jednak, że jest to prawo nieograniczone, dające wszystkim podmiotom pełną swobodę angażowania wymiaru sprawiedliwości we wszystkich przypadkach uznawanych przez te podmioty za wymagające interwencji sądu. Przeciwnie, Konstytucja wyraźnie wyznacza gwarantowany poziom ochrony sądowej. Powołane przez skarżącego wzorce kontroli muszą być więc rozpatrywane $\mathrm{z}$ uwzględnieniem tych przepisów Konstytucji, które określają zakres prawa do sądu, w szczególności: art. 78 przyznającego prawo zaskarżenia orzeczeń i decyzji wydanych w pierwszej instancji, art. 176 ust. 1 - zawierającego gwarancję dwuinstancyjnego postępowania sądowego oraz art. 176 ust. 2 - pozostawiającego ustawodawcy zwykłemu określenie ustroju, właściwości sądów oraz postępowania przed sądami. Konstytucja statuuje więc tylko podstawowe zasady, jakim musi odpowiadać wymiar sprawiedliwości w demokratycznym państwie prawnym. Nie ma podstaw, by konstytucyjne prawo do sądu rozszerzać poza granice wyznaczone przez powołane przepisy. W konsekwencji, trzeba się zgodzić z tezą, że Konstytucja nie gwarantuje ani powszechnego prawa do kontroli orzeczenia przez trzecią instancję (kasacja), ani jakiegoś ogólnego prawa do wznawiania postępowania”. Pogląd, że: 
„(...) z art. 45 Konstytucji nie wynika uprawnienie do żądania ponownego rozpoznania sprawy zakończonej prawomocnym orzeczeniem sądowym” wyrażony został przez Trybunał Konstytucyjny również w postanowieniach z: 18 stycznia 2006 r. (sygn. akt Ts 55/05) i 28 lutego 2006 r. (sygn. akt Ts 218/05). W kolejnych orzeczeniach Trybunału stanowisko to stało się podstawą odmowy nadania biegu skargom konstytucyjnym z uwagi na ich oczywistą bezzasadność (zob. postanowienia TK z: 29 czerwca 2006 r. i 23 lutego 2007 r., sygn. akt Ts 168/05; 22 maja 2007 r., sygn. akt Ts 245/06).

Odmienne stanowisko Trybunał Konstytucyjny zajął m.in. w wyrokach z: 13 maja 2002 r. (sygn. akt SK 32/01) i 21 lipca 2009 r. (sygn. akt K 7/09). W orzeczeniach tych Trybunał wywiódł prawo do żądania wznowienia postępowania $\mathrm{z}$ rygorów, jakim powinna odpowiadać sprawiedliwa (rzetelna) procedura sądowa. W wyroku z 21 lipca 2009 r. (sygn. akt 7/09) Trybunał wskazał m.in., że w jego ocenie: „(...) wymóg ukształtowania procedury sądowej zgodnie ze standardami sprawiedliwości proceduralnej obejmuje nakaz ustanowienia rozwiązań, które zapewnią jednostce adekwatną ochronę przed prawomocnymi orzeczeniami, obarczonymi szczególnie poważnymi wadami i naruszającymi wartości konstytucyjne. Wymóg ten dotyczy prawomocnych orzeczeń sądowych opartych na błędnych ustaleniach faktycznych w sytuacji, w której pojawiają się nowe dowody, niebrane pod uwagę przez sąd rozpoznający sprawę. Ustawodawca, kształtując prawo do wznowienia postępowania w takiej sytuacji, musi jednak szczególnie starannie wyważyć wszystkie kolidujące wówczas wartości, uwzględniwszy szczególne znaczenie stabilności prawomocnych orzeczeń sądowych jako wartości konstytucyjnej”.

Brak pełnej jednolitości judykatury Trybunału Konstytucyjnego w kwestii adekwatności art. 45 ust. 1 (a także art. 77 ust. 2) Konstytucji do oceny konstytucyjności przepisów regulujących przesłanki dopuszczalności oraz sposób ukształtowania przez ustawodawcę procedur z nadzwyczajnych środków zaskarżenia - w szczególności ze skargi o wznowienie postępowania - przekłada się także na sposób prezentacji wniosków Sejmu w toczących się w tej mierze postępowaniach przed Trybunałem Konstytucyjnym (zob. przykładowo stanowiska Sejmu w sprawach o sygn. akt K 7/09 czy też SK 11/09). Jak wskazano, w najnowszym orzecznictwie Trybunału Konstytucyjnego wydaje się dominować stanowisko, które uznaje art. 45 ust. 1 Konstytucji za relewantny wzorzec kontroli procedury wznowieniowej, chociaż równocześnie przyznaje nieco niższy standard przewidzianych wówczas gwarancji prawa do sądu (zob. wyroki TK z: 15 maja 2000 r., sygn. akt SK 29/99; 10 lipca 2000 r., sygn. akt SK 12/99; 13 maja 2002 r., sygn. akt SK 32/01; 11 czerwca 2002 r., sygn. akt SK 5/02; 6 października 2004 r., sygn. akt SK 23/02; 27 października 2004 r., sygn. akt SK 1/04; 31 marca 2005 r., sygn. akt SK 26/02; 2 września 2008 r., sygn. akt K 35/06; 21 lipca 2009 r., sygn. akt K 7/09; 11 maja 2011 r., sygn. akt SK 11/09). W konsekwencji, pogląd taki zostanie przyjęty również w niniejszej sprawie. 
6. Powyższe uwagi nie mogą przesłonić faktu, że w sytuacji, w której ustawodawca wprowadza - w określonym zakresie, wyznaczonym zarówno przez przesłanki (podstawy) wznowienia, jak i termin do wystąpienia ze stosowną skargą - instytucję wznowienia postępowania (tutaj: postępowania sądowoadministracyjnego), powinien równocześnie ukształtować tę instytucję w sposób uwzględniający zasady i wartości konstytucyjne, w tym inkorporowane w art. 45 ust. 1, art. 77 ust. 2, art. 78 czy też art. 176 ust. 1 Konstytucji. W analizowanym przypadku dotyczy to dopuszczalności i zasad kontroli postanowienia o odrzuceniu skargi o wznowienie.

7. Podstawowym konstytucyjnym uzasadnieniem ograniczenia (wyłączenia) możliwości zaskarżenia postanowienia Naczelnego Sądu Administracyjnego o odrzuceniu skargi o wznowienie postępowania przed NSA mogą być względy zazwyczaj przywoływane jako racja dla wytyczenia ścisłych ram, w jakich może funkcjonować instytucja wznowienia postępowania, tj. formalny aspekt zasady państwa prawnego i zasada ochrony zaufania do państwa, wymienione w art. 31 ust. 3 Konstytucji przesłanki „porządku publicznego” oraz „wolności i praw innych osób” (tutaj: innych uczestników „bazowego” postępowania), czy też - również stanowiące komponent prawa do sądu prawo do rozstrzygnięcia sprawy w rozsądnym terminie, dążenie do zapewnienia stanu „pokoju prawnego” między stronami (uczestnikami) sporu oraz ostateczne, stabilne ukształtowanie ich sytuacji prawnej, czego operacjonalizację stanowi instytucja prawomocności orzeczeń.

W doktrynie podkreśla się, że instytucja wznowienia postępowania ma zapewnić racjonalną stabilność merytorycznego orzeczenia i autorytet sądu, który je wydał (zob. K. Sobieralski, Wznowienie postępowania, op. cit., s. 49-50), każdy spór sądowy powinien znaleźć swoje ostateczne, skuteczne i niepodważalne rozstrzygnięcie, a niewzruszalność prawomocnych orzeczeń nie jest wprawdzie regułą absolutną, ale odstępstwa od niej muszą być oceniane z punktu widzenia wartości konstytucyjnych i przy założeniu, że sama reguła jest składową klauzuli demokratycznego państwa prawnego. Również w orzecznictwie Trybunału Konstytucyjnego wskazuje się, że: „[p]rawomocność jest sama w sobie wartością konstytucyjną. Przywracanie stanu stałości, pewności i bezpieczeństwa prawnego (...) zasługuje na ochronę $\mathrm{w}$ ramach zjawisk właściwych dla państwa prawa (w płaszczyźnie generalnej) i jako finalny cel, któremu służy konstytucyjne prawo do sądu - w perspektywie indywidualnej i konkretnej. Dlatego podważenie prawomocności musi każdorazowo być przedmiotem skrupulatnego ważenia wartości" (wyrok TK z 24 października 2007 r., sygn. akt SK 7/06; zob. także wyroki TK Z: 19 lutego 2003.r, sygn. akt P 11/03; 20 maja 2003 r., sygn. akt SK 10/02; 17 maja 2004 r., sygn. akt SK 32/03; 28 listopada 2006 r., sygn. akt SK 19/05; 14 października 2008 r., sygn. akt SK 6/07; postanowienia TK z: 5 marca 2008 r., sygn. akt SK 95/06, i 21 kwietnia 2015 r., sygn. akt SK 52/12). Prawomocne rozstrzygnięcie, które nie może zostać zmienione w następstwie złożenia skargi o wznowienie 
postępowania, umożliwia stronom zakończonego postępowania ułożenie swych spraw według własnych preferencji oraz przyjęcie odpowiedzialności za swoje decyzje. W tym zaś kontekście przypomina się, że wywodzona z zasady demokratycznego państwa prawnego zasada zaufania do państwa i stanowionego przez nie prawa: „opiera się na pewności prawa, a więc takim zespole cech przysługujących prawu, które zapewniają jednostce bezpieczeństwo prawne; umożliwiają jej decydowanie o swoim postępowaniu w oparciu o pełną znajomość przesłanek działania organów państwowych oraz konsekwencji prawnych, jakie jej działania mogą pociągnąć za sobą. Jednostka winna mieć możliwość określenia zarówno konsekwencji poszczególnych zachowań i zdarzeń na gruncie obowiązującego w danym momencie stanu prawnego jak też oczekiwać, że prawodawca nie zmieni ich w sposób arbitralny" (wyrok TK z 14 czerwca 2000 r., sygn. P 3/00; zob. również wyrok TK z 8 maja 2000 r., sygn. akt SK 22/99).

Z perspektywy gwarancji proceduralnych, które system prawny powinien przyznawać i zabezpieczać na rzecz strony postępowania sądowoadministracyjnego zainteresowanej potencjalnie jego wznowieniem, wymaga jednak ustalenia, czy istotnie są powody, dla których stabilność sytuacji prawnej ukształtowanej prawomocnym wyrokiem miałaby zostać ukształtowana na różnym poziomie w zależności od tego, czy prawomocny wyrok lub postanowienie kończące postępowanie w sprawie zostało wydane przez wojewódzki sąd administracyjny czy też Naczelny Sąd Administracyjny, orzekający jako sąd drugiej instancji. Nie sposób przy tym pominąć faktu, iż skarga o wznowienie jest środkiem zaskarżenia względnie suspensywnym: jej wniesienie nie tamuje bowiem wykonania zaskarżonego orzeczenia, chociaż w przypadku, gdy zgłaszający wniosek o wstrzymanie wykonania orzeczenia uprawdopodobni, że grozi mu niepowetowana szkoda, sąd może wstrzymać wykonanie tego orzeczenia.

7. Jako argument na rzecz ograniczenia (wyłączenia) możliwości zaskarżenia postanowienia Naczelnego Sądu Administracyjnego odrzucającego skargę o wznowienie postępowania przed NSA można przytoczyć wzgląd na szczególną pozycję ustrojową tego sądu oraz model postępowania odwoławczego przed NSA. Naczelny Sąd Administracyjny jest bowiem sądem drugiej instancji, rozpoznającym - po myśli art. $15 \$ 1$ pkt 1 p.p.s.a. - środki odwoławcze (zażalenia i skargi kasacyjne) od orzeczeń wojewódzkich sądów administracyjnych, stosownie do przepisów tej ustawy. Natomiast ustawa ta nie zawiera przepisu, który dopuszczałby możliwość rozpoznawania w trybie określonym w jej przepisach skargi kasacyjnej bądź zażalenia od orzeczeń wydanych przez Naczelny Sąd Administracyjny - chociażby do innego, równoległego składu tego sądu (w procedurze cywilnej tzw. zażalenie poziome). Jest to związane z ustrojową rolą NSA jako sądu odwoławczego wyłącznie w stosunku do wojewódzkich sądów administracyjnych oraz wprowadzeniem dwuinstancyjnego modelu sądownictwa administracyjnego (zob. A. Wiktorowska, Pozycja prawna sądów administracyjnych i postępowanie przed sądami administracyjnymi [w:] Postępowanie admini- 
stracyjne - ogólne, podatkowe, egzekucyjne i przed sadami administracyjnymi, red. M. Wierzbowski, Warszawa 2013, s. 408; E. Ochendowski, Zakres kontroli sądów administracyjnych i ich właściwość [w:] M. Jaśkowska, M. Masternak, E. Ochendowski, Postępowanie sądowoadministracyjne, Warszawa 2011, s. 78; postanowienie NSA z 14 kwietnia 2004 r., sygn. akt GSK 68/04). W konsekwencji utrwalił się - kontestowany przez skarżącą, aczkolwiek bezwyjątkowy na tle przepisów ustawy - Prawo o postępowaniu przed sądami administracyjnymi - pogląd, że od wyroków i postanowień wydanych przez Naczelny Sąd Administracyjny nie przysługuje żaden środek odwoławczy, o którym mowa wyżej (zob. przykładowo postanowienie NSA z 22 lutego 2011 r., sygn. akt II GZ 224/10). Orzeczenia takie stają się zatem orzeczeniami prawomocnymi z chwilą ich ogłoszenia (zob. postanowienia NSA z: 4 kwietnia 2008 r., syn. akt II GZ 187/07; 27 maja 2008 r., sygn. akt II GSK 254/07; wyrok WSA w Warszawie z 24 sierpnia 2005 r., sygn. akt IV SA/Wa 446/05). Kontrola działalności administracji publicznej dokonywana przez NSA na podstawie art. $15 \$ 1$ pkt 1 p.p.s.a. nie oznacza powtórnego badania legalności zaskarżonego aktu administracyjnego w jego całokształcie. W postępowaniu wywołanym skargą kasacyjną Naczelny Sąd Administracyjny ocenia bowiem wyłącznie prawidłowość działania sądu administracyjnego pierwszej instancji (zob. szerzej: wyrok NSA z 28 stycznia 2005 r., sygn. akt FSK 1418/04).

8. Dopuszczenie możliwości zaskarżenia skargą kasacyjną postanowienia Naczelnego Sądu Administracyjnego odrzucającego skargę o wznowienie postępowania przed NSA byłoby trudne do pogodzenia również z modelem skargi kasacyjnej przyjętym na tle przepisów ustawy - Prawo o postępowaniu przed sądami administracyjnymi. W świetle art. 173 i n. p.p.s.a. skarga kasacyjna ma bowiem charakter środka odwoławczego przysługującego od wydanych przez sąd pierwszej instancji nieprawomocnych wyroków i postanowień kończących postępowanie w sprawie (z pewnymi wyjątkami wprowadzonymi wzmiankowaną na wstępie nowelizacją przywołanego przepisu). Skarga kasacyjna nie przysługuje natomiast od orzeczeń sądu kasacyjnego oraz orzeczeń prawomocnych.

9. Odnosząc się do argumentów skarżącej, dotyczących naruszenia standardów wynikających z art. 45 ust. 1, art. 78 i art. 176 ust. 1 Konstytucji, należy odwołać się natomiast do specyfiki skargi o wznowienie postępowania jako instytucji, która łączy cechy środka zaskarżenia oraz powództwa o charakterze kształtującym (zob. P. Szustakiewicz, A. Skoczylas, Prawo o postępowaniu przed sqdami administracyjnymi. Komentarz, Warszawa 2016, komentarz do art. 270, nb 3). Skarga o wznowienie prowadzi w rezultacie do wszczęcia postępowania będącego kontynuacją procesu zakończonego prawomocnym orzeczeniem sądu administracyjnego (zob. R. Hauser, W. Piątek [w:] System prawa administracyjnego, t. X, Sądowa kontrola administracji publicznej, Warszawa 2014, s. 571-573). Skarga o wznowienie inicjuje wprawdzie nowe postępowanie sądowe, niemniej pozostaje ono w ścisłej łączności z postępowaniem zakończonym prawomocnym orzeczeniem sądu administracyjnego. Odrębność postępowania zainicjowanego 
skargą o wznowienie jest określana w doktrynie jako ściśle technicznoprawna; $\mathrm{z}$ materialnego punktu widzenia wznowienie postępowania polega na rozpoznaniu i rozstrzygnięciu sprawy zakończonej prawomocnym orzeczeniem (zob. W. Piątek [w:] R. Hauser, W. Piątek, J. Skoczylas, Środki zaskarżenia w postępowaniu sadowoadministracyjnym wraz $z$ wzorami pism procesowych, Warszawa 2013, s. 365-366). W powiązaniu z nadzwyczajnym charakterem tego środka zaskarżenia uprawnia to do stwierdzenia, że rygory związane z zapewnieniem i zabezpieczeniem w drodze postępowania odwoławczego od postanowienia o odrzuceniu skargi o wznowienie odpowiedniego poziomu sprawiedliwości proceduralnej mogą być $w$ tym przypadku łagodniejsze niż w przypadku zwykłego postępowania sądowoadministracyjnego, nakierowanego bezpośrednio na kontrolę działalności administracji publicznej. W związku zaś z faktem, że postępowanie ze skargi o wznowienie postępowania stanowi (lub może stanowić) kontynuację postępowania zakończonego prawomocnym orzeczeniem kończącym postępowanie sądowoadministracyjne, nie powinno być ono postrzegane w izolacji od tego postępowania głównego z punktu widzenia wymogów dwuinstancyjności i zaskarżalności orzeczeń wydanych w pierwszej instancji.

10. Reasumując, należy uznać, że art. $173 \$ 1$ p.p.s.a. w zakresie, w jakim nie przewiduje możliwości zaskarżenia skargą kasacyjną postanowienia Naczelnego Sądu Administracyjnego odrzucającego skargę o wznowienie postępowania przed Naczelnym Sądem Administracyjnym, jest zgodny z art. 45 ust. 1 w związku $\mathrm{z}$ art. 32 ust. 1 oraz art. 78 i art. 176 ust. 1 Konstytucji i nie jest niezgodny $\mathrm{z}$ art. 77 ust. 2 Konstytucji. Jednocześnie $\mathrm{z}$ ostrożności procesowej należy podkreślić, że nawet przyznanie skarżącej - na podstawie ewentualnego wyroku Trybunału Konstytucyjnego stwierdzającego zakresową niekonstytucyjność art. 173 $\$ 1$ p.p.s.a. - prawa do uruchomienia kontroli instancyjnej postanowienia o odrzuceniu wniesionej przez nią skargi o wznowienie nie oznacza wcale pozytywnej perspektywy dla uwzględnienia tej skargi i uchylenia wcześniejszych, niekorzystnych dla niej decyzji czy też orzeczeń w sprawie.

\section{Bibliografia}

Adamiak B. [w:] B. Adamiak, J. Borkowski, Postępowanie administracyjne i sadowoadministracyjne, Warszawa 2015.

Banaszak B., Konstytucja RP. Komentarz, Warszawa 2009.

Czeszejko-Sochacki Z., Formy naruszenia konstytucyjnych wolności lub praw [w:] Skarga konstytucyjna, red. J. Trzciński, Warszawa 2000.

Czeszejko-Sochacki Z., Prawo do sq̨du w świetle Konstytucji Rzeczypospolitej Polskiej, „Państwo i Prawo” 1997, z. 11-12.

Garlicki L., Komentarz do art. 176 [w:] Konstytucja Rzeczypospolitej Polskiej. Komentarz, t. IV, red. L. Garlicki, Warszawa 2005. 
Hauser R., Piątek W. [w:] System prawa administracyjnego, t. X, Sądowa kontrola administracji publicznej, Warszawa 2014.

Jakubecki A., Kilka uwag o instancyjności postępowania cywilnego na tle orzecznictwa Trybunału Konstytucyjnego [w:] Orzecznictwo Trybunału Konstytucyjnego a Kodeks postępowania cywilnego, red. T. Ereciński, K. Weitz, Warszawa 2010.

Jamróz L., Skarga konstytucyjna. Wstępne rozpoznanie, Białystok 2011.

Kabat A., Komentarz do art. 278 [w:] Prawo o postępowaniu przed sq̨dami administracyjnymi. Komentarz, B. Dauter, B. Gruszczyński, A. Kabat, M. Niezgódka-Medek, 2013, LEX.

Kabat A. [w:] B. Dauter, B. Gruszczyński, A. Kabat, M. Niezgódka-Medek, Prawo o postępowaniu przed sąami administracyjnymi. Komentarz, 2016, LEX.

Knysiak-Molczyk H. [w:] Postępowanie sądowoadministracyjne, red. T. Woś, Warszawa 2004.

Maciejko W., Wznowienie postępowania sq̨dowoadministracyjnego na skutek wyroku Trybunału Konstytucyjnego, „Casus. Kwartalnik Krajowej Reprezentacji Samorządowych Kolegiów Odwoławczych” 2006, nr 39.

Ochendowski E., Zakres kontroli sądów administracyjnych i ich właściwość [w:] M. Jaśkowska, M. Masternak, E. Ochendowski, Postępowanie sqdowoadministracyjne, Warszawa 2011.

Piątek W. [w:] R. Hauser, W. Piątek, J. Skoczylas, Środki zaskarżenia w postępowaniu sądowoadministracyjnym wraz z wzorami pism procesowych, Warszawa 2013.

Pietrzykowski H., Prawo do sądu, „Przegląd Sądowy” 1999, nr 11-12.

Sobieralski K., Wznowienie postępowania sq̨dowoadministracyjnego, Warszawa 2013.

Szustakiewicz P., Skoczylas A., Prawo o postępowaniu przed sądami administracyjnymi. Komentarz, Warszawa 2016.

Tarno J.P., Prawo o postępowaniu przed sądami administracyjnymi. Komentarz, Warszawa 2011.

Tuleja P. [w:] Prawo konstytucyjne RP, red. P. Sarnecki, Warszawa 1999.

Zembrzuski T., Zaskarżanie orzeczeń incydentalnych wydanych po raz pierwszy $w$ toku instancji (uwagi na tle wyroku Trybunału Konstytucyjnego), „Przegląd Sądowy” 2007, nr 9. 